\title{
Manurau: \\ A conceptual framework of Māori leadership practice in the New Zealand public sector
}

By

Daryn Bean

A thesis submitted to the Victoria University of Wellington in fulfilment of the requirements for the degree of

Doctor of Government

Victoria University of Wellington

2018 


\section{Table of Contents}

Abstract

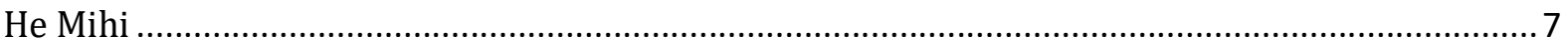

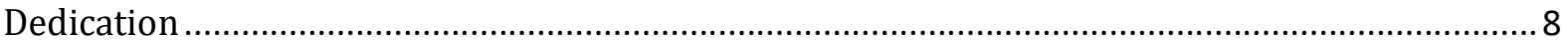

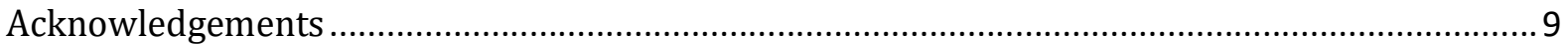

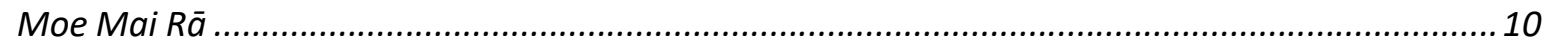

List of Figures

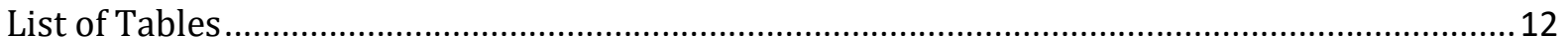

Chapter One: Introduction $\ldots \ldots \ldots \ldots \ldots$

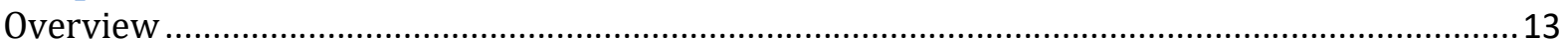

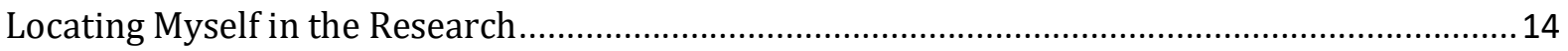

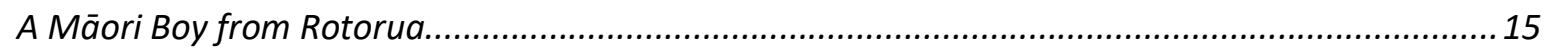

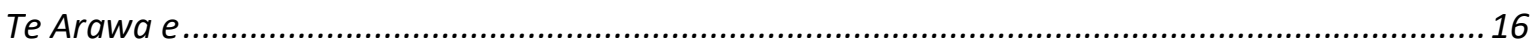

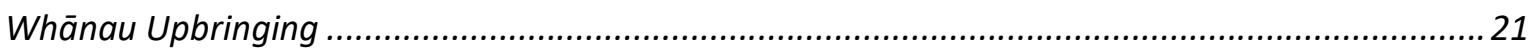

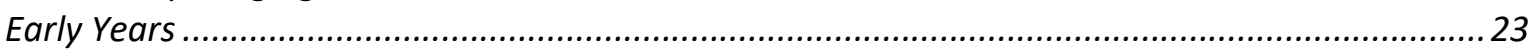

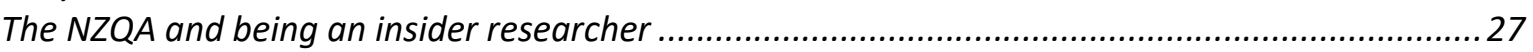

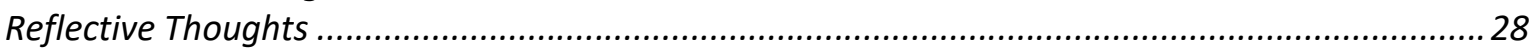

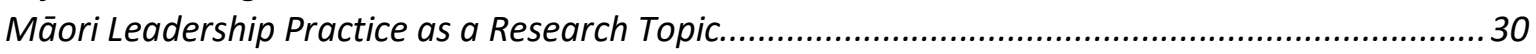

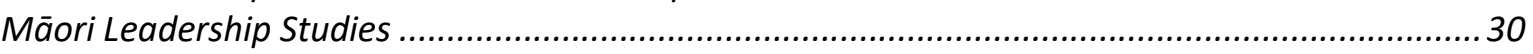

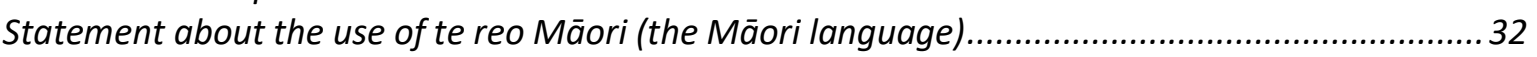

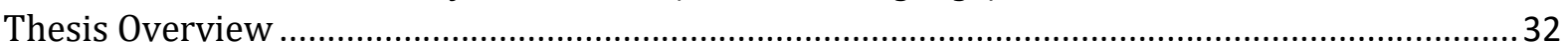

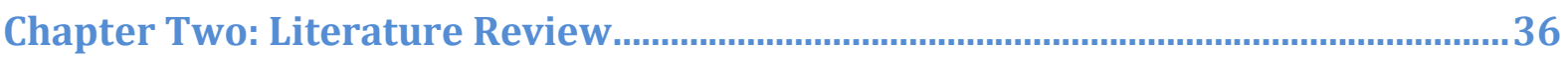

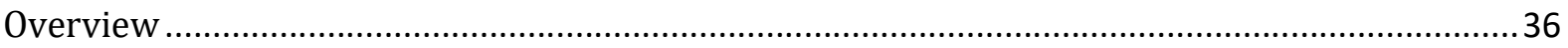

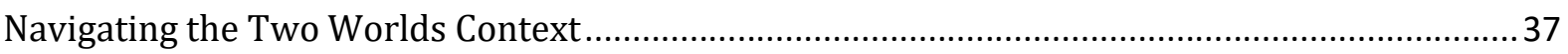

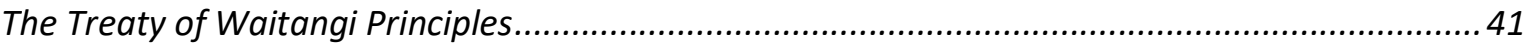

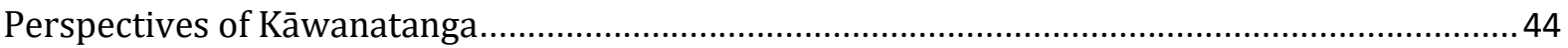

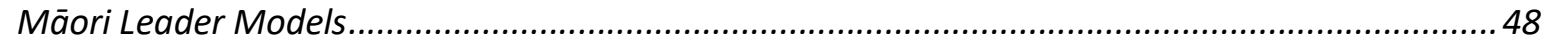

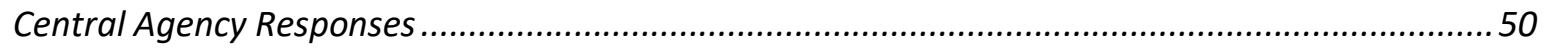

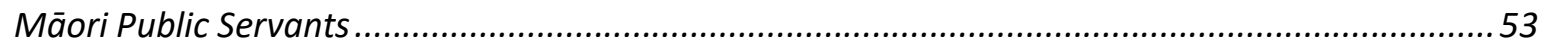

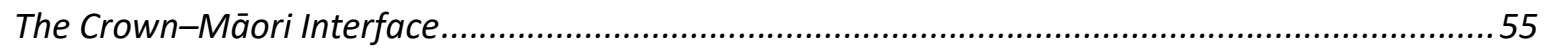

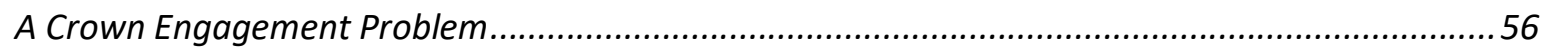

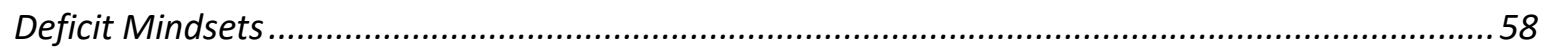

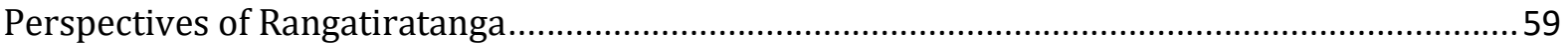

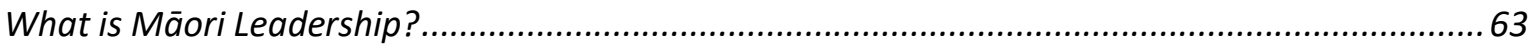

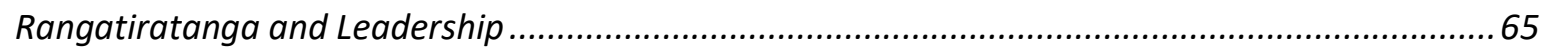

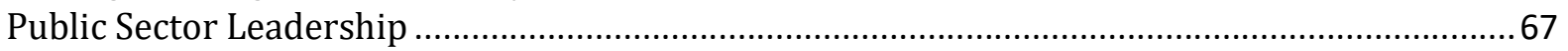

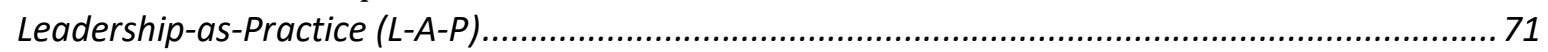

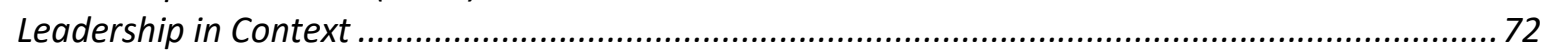

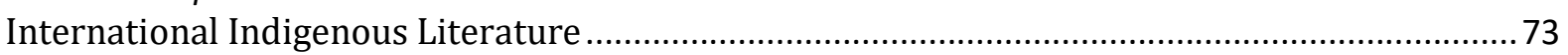

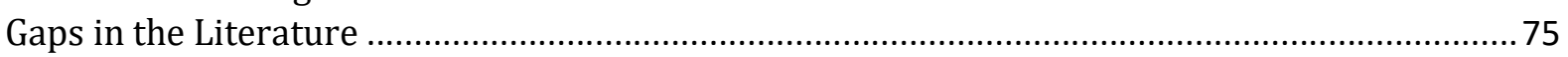

Chapter Three: Research Design and Methodology $\ldots \ldots \ldots \ldots \ldots \ldots \ldots \ldots \ldots \ldots \ldots \ldots \ldots \ldots \ldots \ldots$

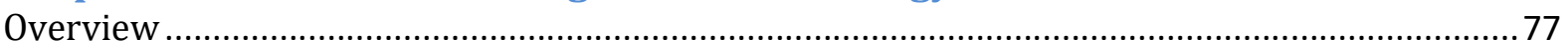

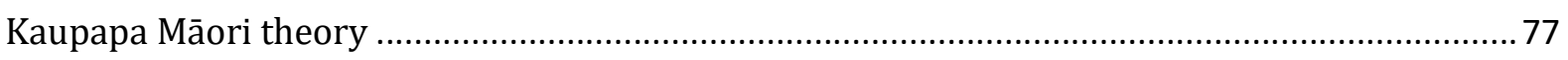

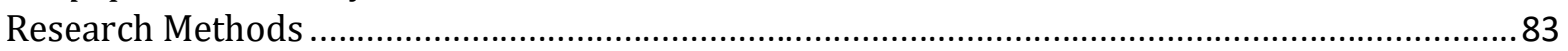

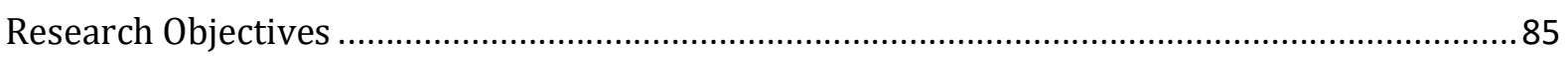

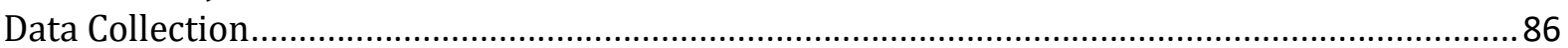




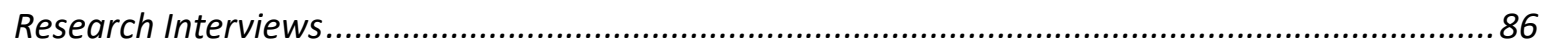

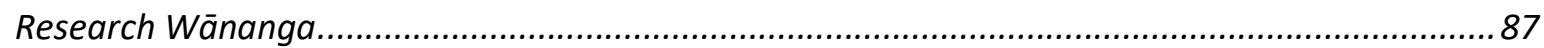

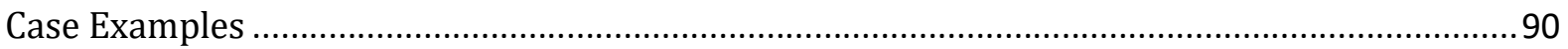

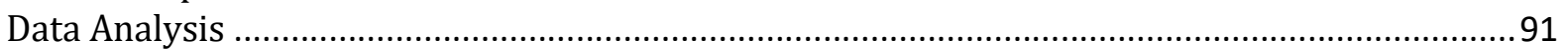

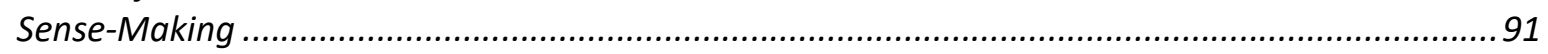

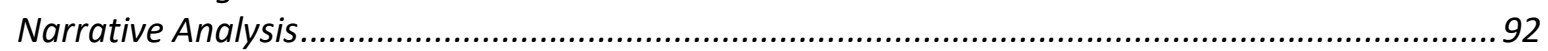

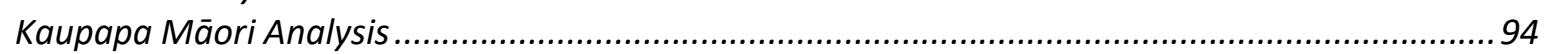

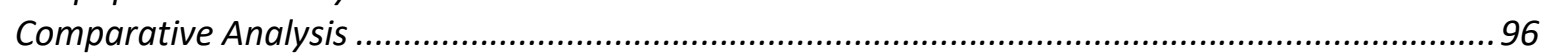

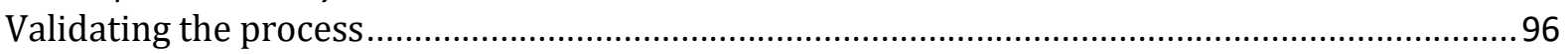

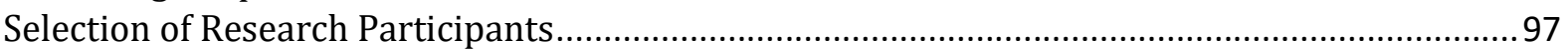

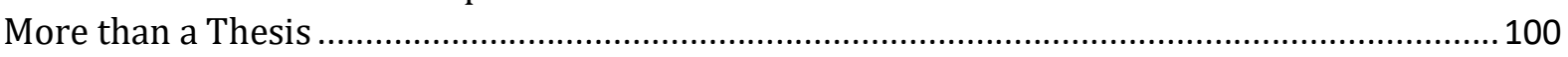

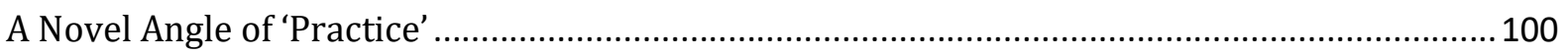

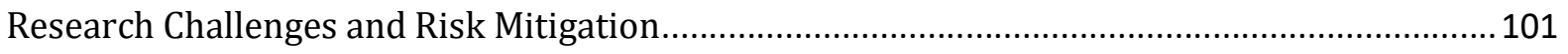

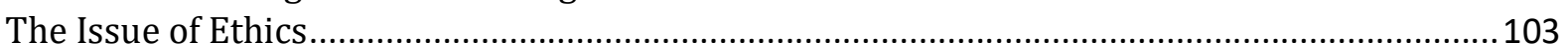

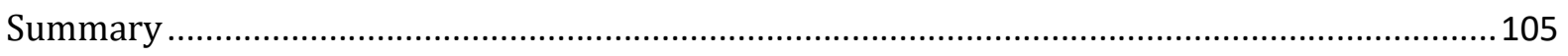

Chapter Four: What do the Voices of Lived Experience Tell us of Leadership? ... 107

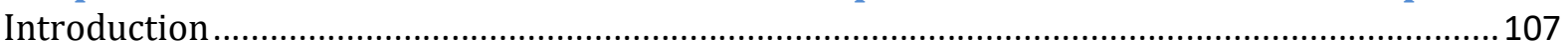

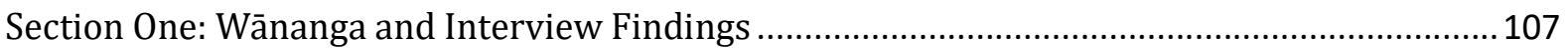

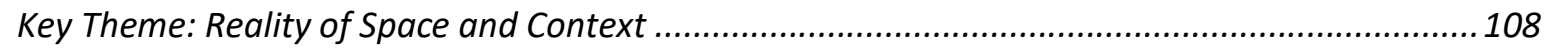

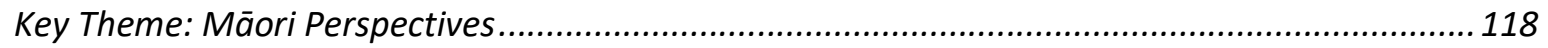

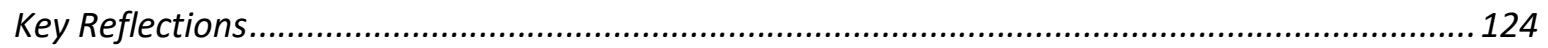

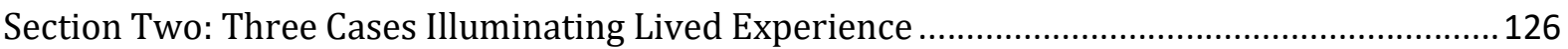

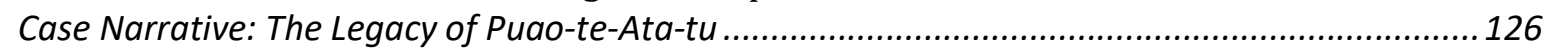

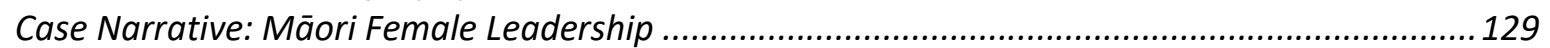

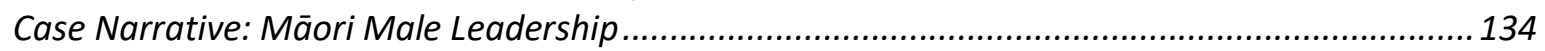

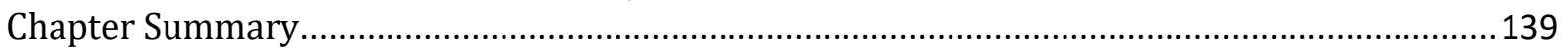

Chapter Five: The New Zealand Qualifications Authority...................................... 141

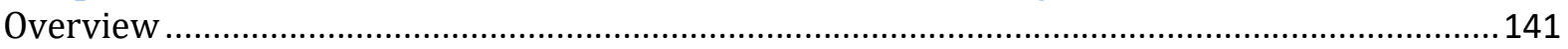

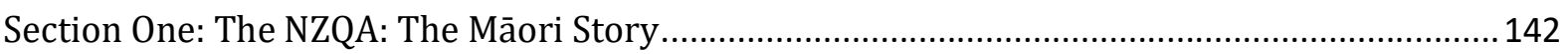

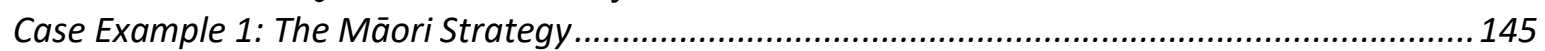

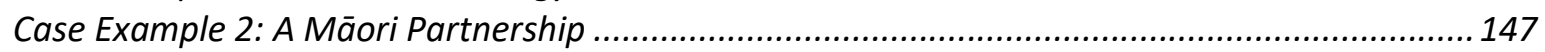

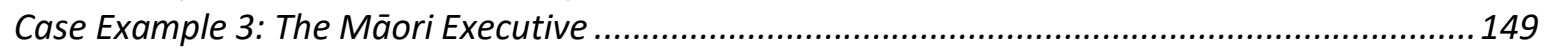

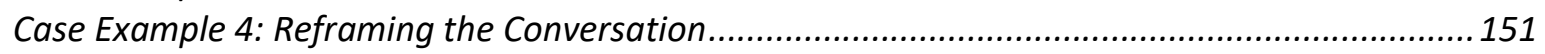

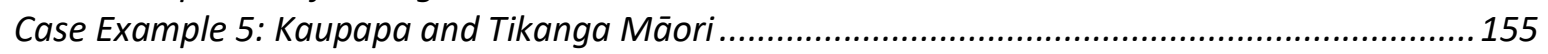

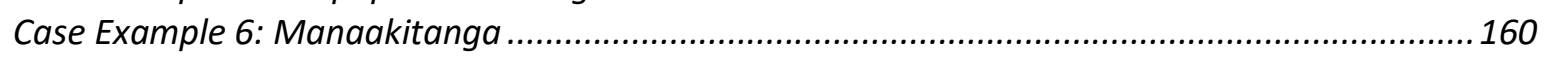

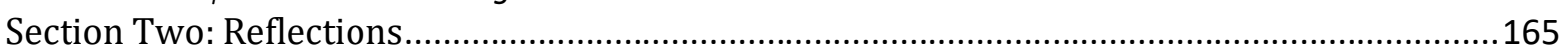

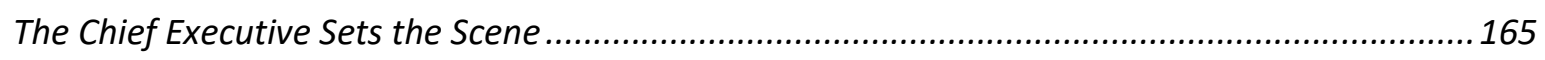

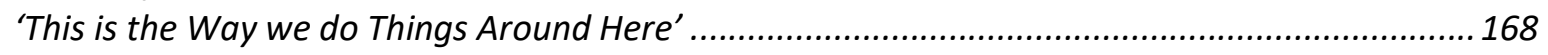

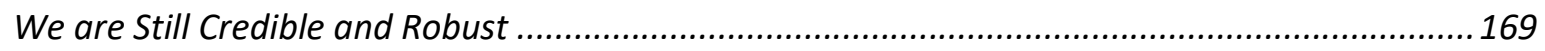

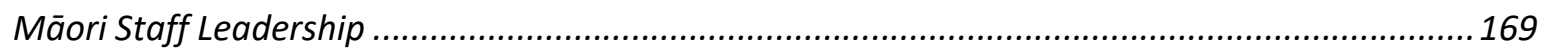

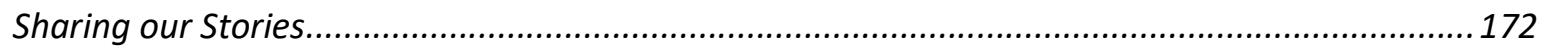

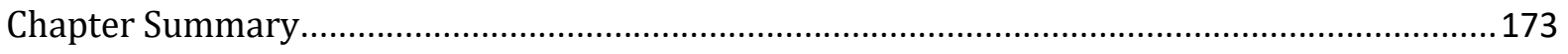

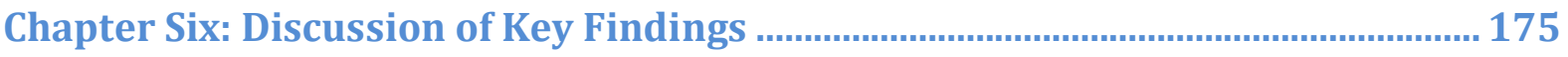

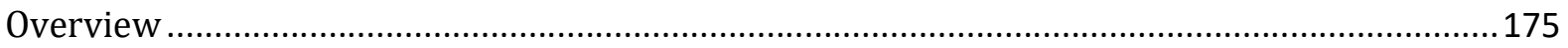

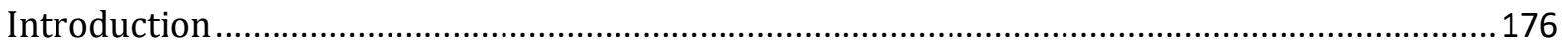

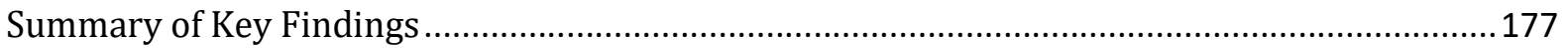

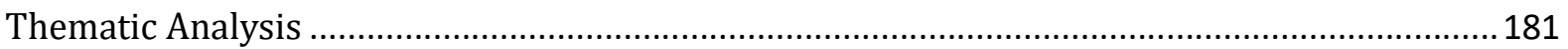

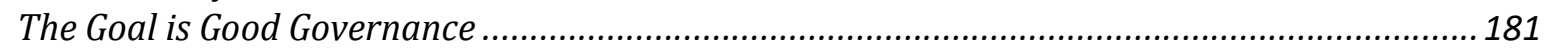

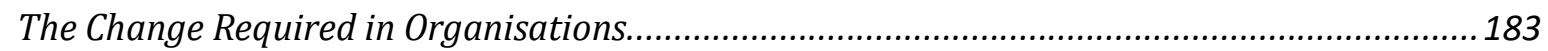

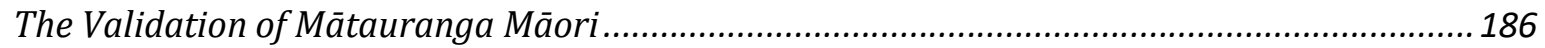




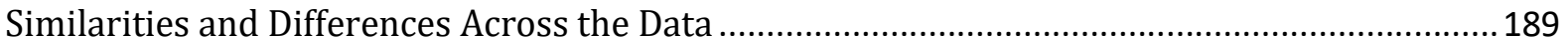

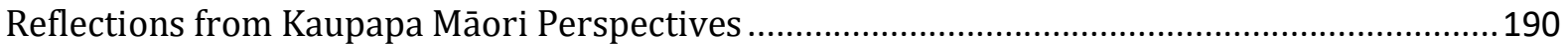

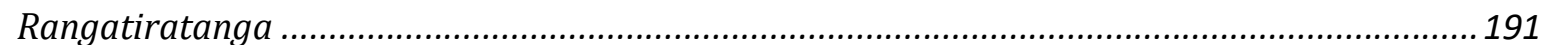

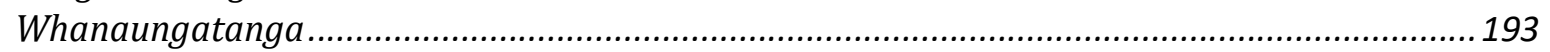

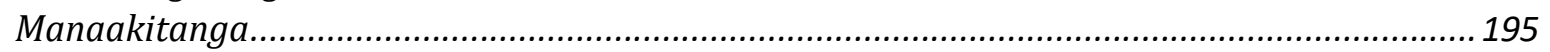

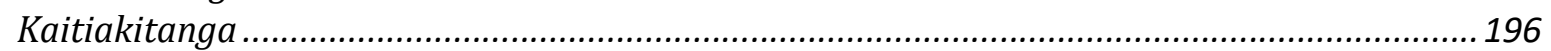

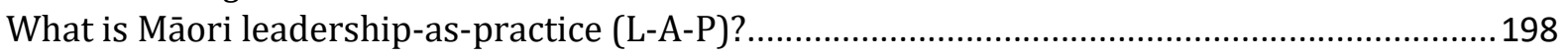

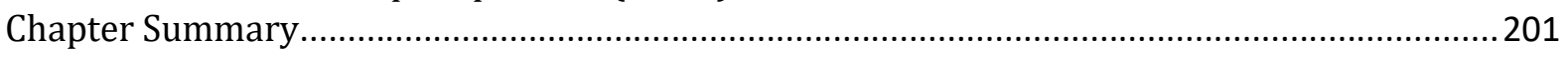

\section{Chapter Seven: Manurau: Developing a Conceptual Framework of Māori}

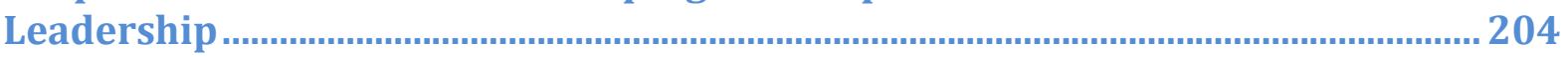

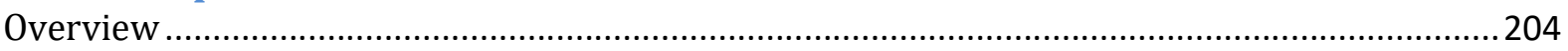

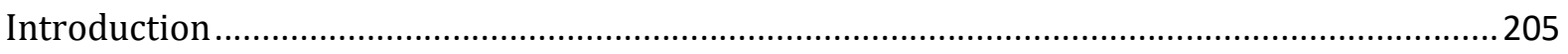

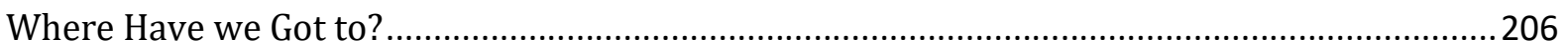

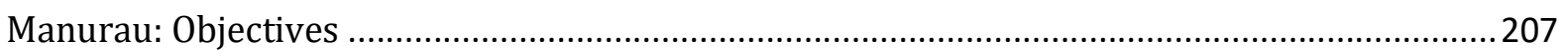

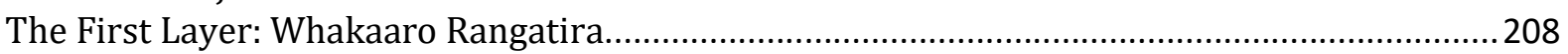

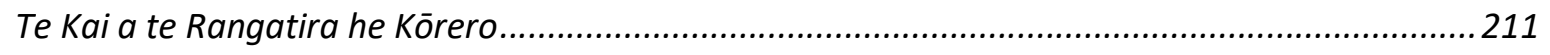

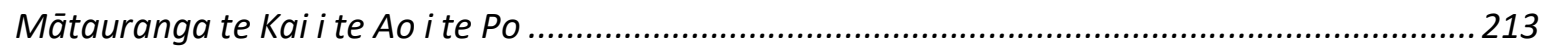

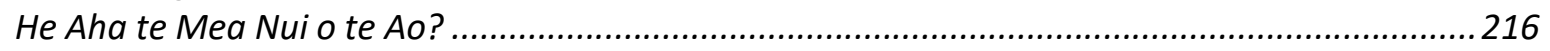

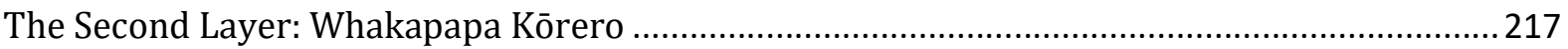

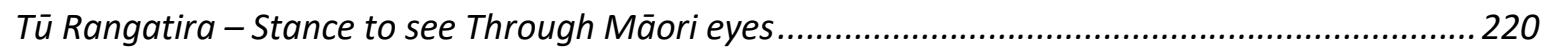

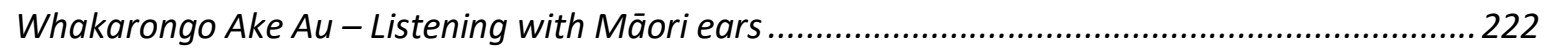

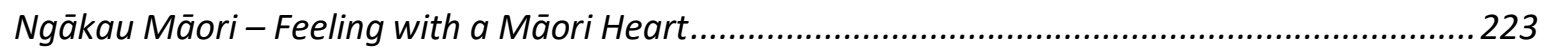

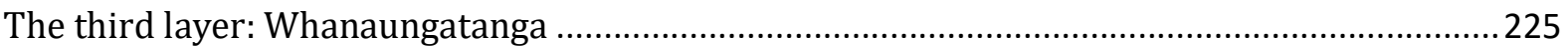

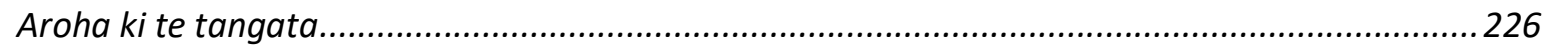

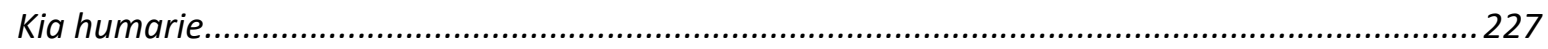

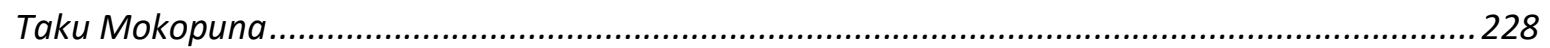

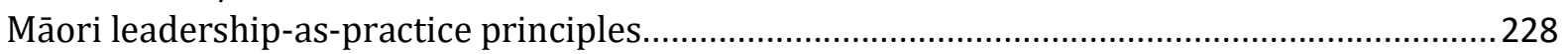

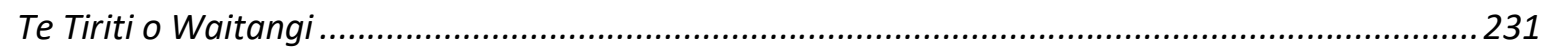

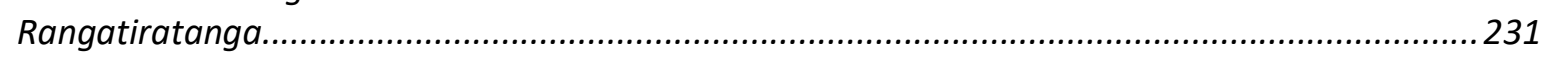

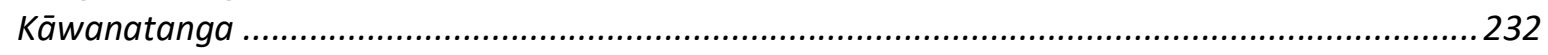

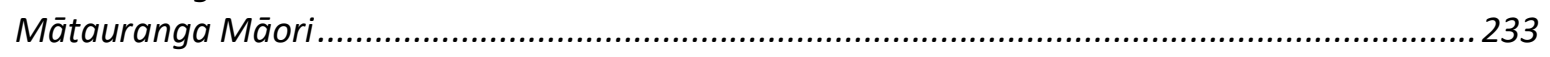

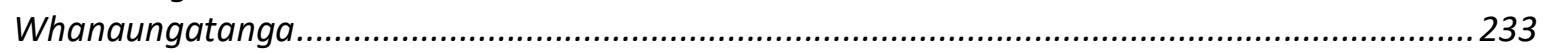

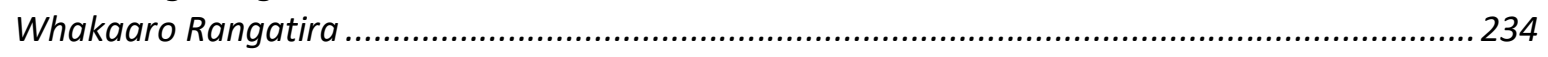

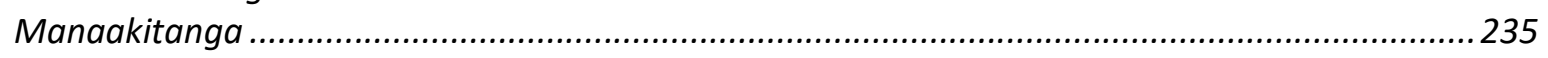

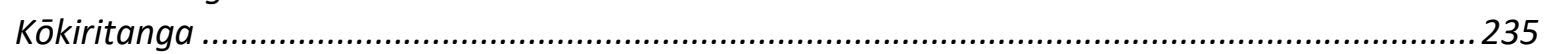

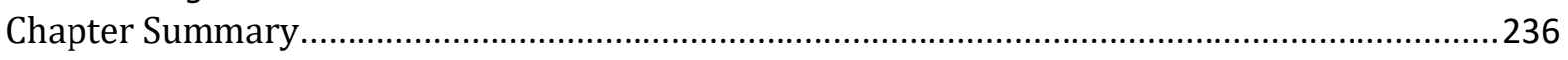

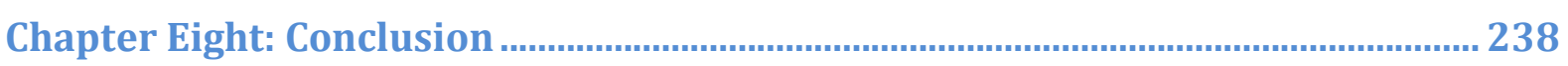

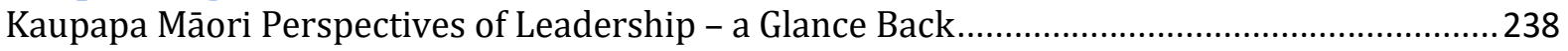

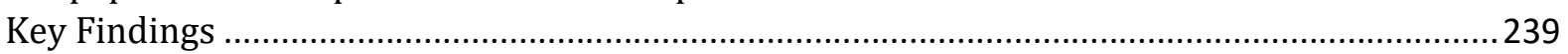

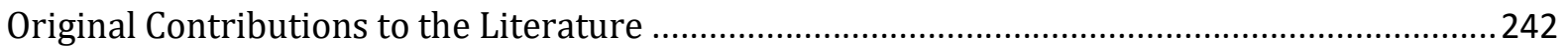

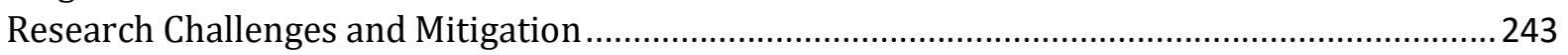

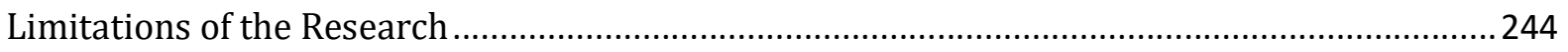

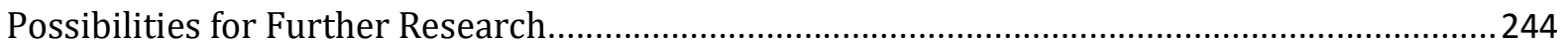

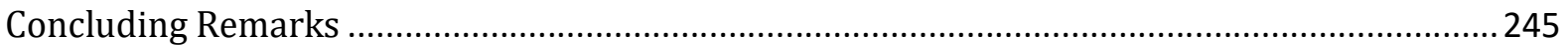

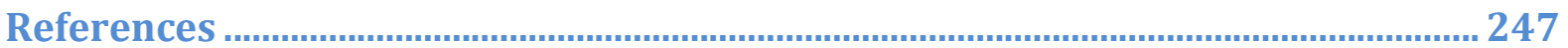




\section{Abstract}

This kaupapa Māori examination of Māori leadership in the New Zealand public sector reveals that the experience of Māori working in government agencies is neither well understood nor specifically addressed in the fields of public administration and publicsector leadership. The study found that a key leadership practice of Māori public servants is to position themselves strategically and thoughtfully to advance mātauranga Māori and kaupapa Māori. They are public servants who are cognisant of the Crown-Māori spaces in which they occupy. They are careful in their assumptions and views about the underlying forces at play and the responsibility they have in working for government. They are concerned about the legitimate place of mātauranga Māori and kaupapa Māori in kāwanatanga spaces and work to alleviate and mitigate bureaucratic pressures imposed by the dominant Westminster model of governance.

Māori leadership practices are designed and constructed through personal models of leadership shaped by Māori values, legacies, whakapapa, and whānau upbringing. Māori leadership practice has influence beyond the hierarchical structures of kāwanatanga. Metaphorically, Māori public servants are manu kōrero (literally, knowledge birds) who, given the right conditions, would not operate alone singularly, but operate as many birds, as Manurau (literally, one hundred birds). They work inside kāwanatanga - empowering and leading others, expressing rangatiratanga from a position of personal integrity, humility, and authority.

This study applied critical theoretical tools for research and analysis and found answers that are rooted in kaupapa and mātauranga Māori methodologies. Te Arawatanga, as a tribal framework, positions the insider Māori researcher into a safe cultural space to be courageous about expressing rangatiratanga in a kāwanatanga context. Whakapapa analysis grounds the research within a Māori ontology. Whakataukì emphasises the Māori voices and narratives framed within the wisdom of ancestors. This study can be said to rest on the shoulders of those with lived experience who see with Māori eyes, hear with Māori ears and feel with a Māori heart. The significance of this thesis therefore provides a 'starting point' that seeks to legitimate the Māori leadership contribution to 
New Zealand's public service and advocates for greater recognition and validation of Māori leadership practice and indigenous leadership in public administration globally. 
Ka tìmata au nā Ohomairangi Ruamuturangi

Taunga Mawake Uruika

Rangitapu Atuamatua Houmaitawhiti

Tamatekapua Kahumatamomoe

Tawakemoetahanga Uenukumairarotonga

Rangitihi whakahirahira i takaia te upoko ki te akatea

Whano whano tū mai te mauri

Haumi e, hui e, taiki e!

Ko te toi o Tūhourangi kai mātaotao

I moea ki runga takapau wharanui

Kia puta ki waho

Taku mana $\bar{e}$

Tūhourangi Taketakehikuroa Tuteamutu Rangiwewehi

Puraho Te Pipi o te rangi Te Rangipuawhe

Takatu o te rangi Te Whatu o te rangi Rangikaingahuhu Nawaina

Te Rangipuawhe II, Wi Keepa Te Rangipuahwe Te Uruhi Maika

Renati Mita Maika o ngā whare kahui ariki o Tūhourangi me Ngāti Whakaue me

Tapuika Ngāti Moko

E ko koia e ara e

He hōnore he korōria ki te atua

Maungārongo ki te whenua

Whakaaro pai ki ngā tāngata katoa, Amine

E ngā mana, e ngā reo, e ngā karangatanga maha o te motu

Nei rā he mihi maioha ki a koutou me ō koutou tini āhuatanga

Kai ngā mate huhua o te wā

ka mihia ka tangihia ka poroporoakitia anō

Heoi anō rātou te hunga mate ki a rātou, tātou te hunga ora ki a tātou

Tihei mauri ora

E te iwi kai te mihi atu ki a koutou i runga i tēnei kaupapa rangahau kōrero whakaaro rangatira

Na te aha? Kia manaaki i te iwi, nō reira

Tènā koutou, tēnā koutou, tēnā koutou katoa 


\section{Dedication}

To Debbie and whānau

This thesis is dedicated to my beautiful wife, Debbie, who has traversed this journey with me for over 30 years. This journey and thesis is only possible because of Debbie. She has supported me while I chased a rugby ball around, while I pursued an academic pathway, as we moved to Auckland, to South Africa, to Whangarei, and to Wellington. She raised our family and brought love and joy into our whānau through her commitment and dedication to our whānau wellbeing. Debbie does not need academic qualifications. She has lived experience! She knows her stuff and makes stuff happen. It is always perfect. She is beautiful in every way, and I love her dearly. Thanks Deb.

Debbie and I have the best whānau anyone could ever ask for. Sharon and Peter and their children, Jerome, Ashtyn and baby Quinten. Erina and Phil and our little chief, Maika. Lauren and Wesley and our Marley girl. And of course, G. My son Geordie Taituha Bean: love you boy. There will be more mokopuna to come too well after this thesis is complete! And Aunty Shaz, who will do anything for us. Our whānau memories of Nana Jane who sadly passed away whilst I was writing this thesis are real treasures. The joy and laughter (and food) that we enjoyed together with Jane is a testament to the love in our whānau.

To my dad

My dad also passed away whilst I was writing this thesis. Koro Doug - love you my dad; rest in peace. As an adult, I did not spend as much time as I should have with Dad, as I lived and worked away from home, and Dad spent some time away from the whānau after our mum passed away. I think about that quite often. But as he got older we were able to spend some quality time together and he was able to share some of his old yarns about rugby and life in Rotorua as a young man. Dad is now with our mum, Lydia, who passed away in 2000. Mum blessed us with her love - and our Māori side, our Te Arawatanga. I'm happy Mum and Dad are back together again. 
To my sisters and brothers-in-law, Frances and Darrel, Sheree and Perry, Pania, Liana and Darcy, Margaret and Doug, and my awesome nieces and nephews and the extended whānau.

Thank you for being awesome, fun, and a loving whānau. Aroha tino nui.

\section{Acknowledgements}

To my supervisors - Professor Brad Jackson and Associate Professor Bill Ryan

I would like to acknowledge Brad and Bill for giving me the confidence to just be who I am. This was a long hard road, but their supervision and support eased my mind and eased the pressure. Bill is wise beyond measure, and I love his quirky yet thoroughly thoughtful sense of social justice, pragmatism, and reality. Kia ora Bill. Brad is an academic leadership guru and it has been a pleasure to work with Brad and to consider my perspectives of leadership within a broader and global context. All the best Brad.

I also wish to acknowledge the Australia New Zealand School of Government and Victoria University of Wellington for the opportunity to contribute to the study on Indigenous Peoples Experiences' of the Public Sector. I trust this thesis will provide insights to enlighten the Māori experience. My sincere thanks to Bill Ryan, Catherine Althaus, and other members of the indigenous leadership research community.

To my mentors Professor Taiarahia Black and Professor Wiremu Doherty

I need to acknowledge both Tai and Wiremu for their openness and willingness to support my thesis journey. Their advice and support is critical to the study because their influence and leadership has shaped my experience within the public sector. To fulfil my goals of being true and ethical in my approach as a Māori researcher I needed guidance, and Wiremu and Tai provided this. I will be forever grateful for your support and encouragement and the interest you took in me, to be successful.

I would also like to acknowledge past and present members of the New Zealand Qualifications Authority (NZQA)'s Ngā Kaitūhono, including Hone Sadler, the late 
Mauriora Kingi, Liz Hunkin, Shane Edwards, Aneta Wineera, Donna Grant, Hana O’Regan, Rahui Papa, Sophie Tukukino and Sir Hirini Mead, who each played their part of providing advice, insight, and wisdom and lots of laughter throughout my research journey. Ngā mihi nui.

To NZQA Chief Executive (Dr) Karen Poutasi

This thesis would never have been possible without the support of Karen Poutasi. Karen, thank you. The essence of leadership in the public sector is your lived experience, and you continue to provide the benchmark for others to follow. Those innate qualities that are referred to in Māori culture are present in your leadership. Your wisdom and sincerity is beyond measure. You have been relentless in your support of me and totally committed to my success. This to me is the epitome of leadership, you live it every day and it is an absolute privilege to work for you.

To the Office of the Deputy Chief Executive Māori and Office of Pasifika

Finally, a special acknowledgement is paid to my team at NZQA. Thank you for putting up with me over the last few years. You have been absolutely amazing! You allowed me to test my random ideas, you gave me feedback and most of all you had my back in making sure the work continued whilst I was beavering away in my office working on my thesis. You continue to demonstrate leadership in everything you do. I truly appreciate your love and support. This thesis is possible because you made it so.

Moe Mai Rā

The study was undertaken over a five-year period between 2013 and 2018 on a part-time basis while I was working fulltime. Over this period there were Māori public servants who I worked closely with who epitomised Māori leadership who sadly passed away. Our dear Ruth Maniapoto was my executive assistant at NZQA for seven years and passed away on 2 September 2016. The team loved Ruth, as she exuded manaakitanga every day in the way she went about her daily activities and looked after people. Especially me. She gave me special things, such as words like 'humbug', and she always brought a sense of pride when talking about her whānau. Moe mai ra e Ruthie. 
Hika Tangitu passed away on Friday 1 October 2016. Hika was the receptionist at Te Puni Kōkiri and gave 30 years of service. Hika was famous for being 'in the know' and had all the gossip from home. He knew how to make everyone feel important. He would connect through whakapapa kōrero. Hika epitomised manaaki. He was not the chief executive, but he was the most impressive and eloquent of men who would practice and live by Māori values. The loss of Hika reminded me that it does not matter whether you are the receptionist or the chief executive; you bring your acts of leadership with you. Hika leaves a void in the way Te Puni Kōkiri engages with its clients, both Māori and non-Māori. It is not that in future, it will not be any good. It is just that it will not be the way Hika did it. E te rangatira, moe mai rā.

Mauriora Kingi passed away on 2 June 2015. Mauriora and I were meant to travel together to the United Kingdom to visit Hinemihi, after the tragic fire of Clandon Park House in Surrey. Instead, he had a higher calling, and the esteemed orator and tohunga of Tūhourangi-Ngāti Wāhiao was taken from us. Mauriora, in his role with the Rotorua District Council and as a member of Ngā Kaitūhono and Whakaruruhau at the NZQA, operated in the Māori world and in the public domain offering thoughts and wisdom passed down to him by his teachers and ancestors. As he walked and talked, Mauriora impressed upon those who would listen the virtues of tikanga Māori and manaakitanga. E Mau, moe mai rā.

Nō reira, kei ngā mate huhua, moe mai, haere atu, whakangaro atu ki te pō i rite ai ki te kōrero o Mauriora, he pūkenga wai ka puta te rākau, he pūkenga tangata ka puta te kōrero

ko tātou nei te hunga ora e takatū nei i te ao, i te po, taiaha ha, taiaha ha, tihei mauri ora. 
List of Figures

\begin{tabular}{|l|l|l|}
\hline Figure 1. & $\begin{array}{l}\text { Two-worlds context for Māori leadership practice in public } \\
\text { administration }\end{array}$ & p. 38 \\
\hline Figure 2. & A diagram showing NZQA's Ngā Mātāpono (NZQA values) & p.162 \\
\hline Figure 3. & $\begin{array}{l}\text { Takapau Wharanui - the great mat of kaupapa Māori } \\
\text { perspectives of leadership in public administration }\end{array}$ & p. 198 \\
\hline Figure 4. & The whakataukī-based concept of whakaaro rangatira & p.211 \\
\hline
\end{tabular}

\section{List of Tables}

\begin{tabular}{|l|l|l|}
\hline Table 1. & Selected facts about research participants & p. 99 \\
\hline Table 2. & High-level finding: rangatiratanga-kāwanatanga tension & p. 178 \\
\hline Table 3. & High-level finding: the Māori voice in the public sector & p. 179 \\
\hline Table 4. & $\begin{array}{l}\text { High-level finding: recognition of Māori philosophy and } \\
\text { practice }\end{array}$ & p. 180 \\
\hline Table 5. & High-level finding: the place of Māori in the public sector & p. 181 \\
\hline Table 6. & Sample of Māori leadership practices in public administration & p. 191 \\
\hline Table 7. & Two-worlds principles for the New Zealand public sector & p. 229 \\
\hline & Manurau as a conceptual leadership practice framework & p. 231 \\
\hline & & \\
\hline
\end{tabular}




\section{Chapter One: Introduction}

\section{Overview}

The idea to study Māori leadership in public administration has been with me since the early days in my career. I will never forget an evening walk through Ohinemutu with Parekura Horomia. It would be a life-changing experience for me. He told me it was time for me to go to university to complete my business degree. Parekura must have seen something in me. He was prepared to back me, and my resolve is to help others the same way he supported me.

This thesis examines what constitutes Māori leadership practice within a government agency in New Zealand in the twenty-first century. The aim is to identify, describe, and elaborate on the critical concepts of Māori leadership to offer an alternate view to the abstract models of individualistic leadership promoted in Western theory and practice. The significance of this research lies not just in articulating a conceptual framework but demanding a space where the practice in Aotearoa New Zealand is encouraged to emerge, is recognised as a legitimate model to be aspired to by Māori, and is entirely accounted for in general, everyday interaction. The thesis is also relevant to international indigenous scholars and public servants for further comparative study, as there are no systematic studies focusing on the experience and contributions as indigenous public servants, or their leadership role or understandings of what constitutes 'leadership' (Althaus, 2014).

Inspired by what is known by Māori officials who 'walk in two worlds', this thesis is guided by the lived experiences of practitioners in the delivery of public service and Māori development. This thesis seeks to address some gaps that unfortunately exist in public administration and public-sector leadership literature concerning Māori leadership practice in government agencies. Māori academic scholars such as Sir Mason Durie (2004c), Dr Ranginui Walker (1990), Sir Hirini Mead (2003), Linda Smith (2005) and Graham Smith (1997) have, through the momentum of kaupapa Māori theory and praxis, created space to explore Māori leadership in the public sector. Their seminal works have paved the way for a new generation of Māori academics and practitioners to 
take up the challenge and explore opportunities to make original contributions to knowledge.

The distinctive contribution is using the kaupapa Māori theoretical lens for weaving real lived experience with Raelin's (2011) concept of leadership-as-practice (L-A-P) and leaderful practice and Moore's (2005) notion of creating public value, opening a door to a new field of possibilities for indigenous research, Māori perspectives, and leadership development within the public sector.

The position of the researcher, as an insider researcher, Māori, Te Arawa, and senior public servant, refines the perspective of this thesis. Privileging kaupapa Māori methodologies, to interpret and analyse data, integrates kaupapa Māori perspectives with leadership theory. The significance of the research approach is to lay a platform (a) for the integrity and social appropriateness of the New Zealand public sector; (b) for Māori in Aotearoa; and (c) for indigenous peoples in other jurisdictions.

Central to this thesis is the phenomenon of two worlds - the world of the Crown and the world of Māori. Whilst I was developing the research proposal, the potential for a study from the perspective of those who operate at the two-worlds interface became apparent. This qualitative research design sought to ensure Māori voices are 'free to speak' and not be constrained by set questions and formulaic processes. Kaupapa Māori theory allowed Māori methodologies and interpretative analysis to validate lived Māori leadership experience, bringing life to the notion that Māori leadership practice exists in public administration in many forms. Research wānanga, interviews, case examples, and an organisational case study of the New Zealand Qualifications Authority (NZQA) produced rich data and narratives. Data are analysed using kaupapa Māori lenses, producing multilayered perspectives, key themes, and sub-themes.

\section{Locating Myself in the Research}

The initial trepidation in undertaking this thesis was based on the need to establish the worthiness of the thesis topic. As a Māori researcher, who is also working for the government, research choices included adopting kaupapa Māori theory and methods and searching for answers from both philosophical and practical perspectives. I felt uneasy that this thesis might not be recognised as a valid contribution to research by the 
academy, Māori academic community, and central government agencies. Or alternatively, would it be dismissed as a nebulous study promoting Māori values?

The Māori perspectival approach needed to be genuine and sincere and go beyond academic ethical requirements. The act of undertaking Māori research within the context of a dominant Western culture of government and university immediately had the researcher walking in two worlds - living Māori leadership practice.

Locating myself in this thesis is a major part of the Māori leadership narrative. To establish the foundations this section outlines my interests in the kaupapa of Māori leadership, my Te Arawa whakapapa, my early years, and the significance of Māori role models. It goes on to explain my experience of whānau and to what extent whānau and whānau upbringing influence how Māori leadership practice is enacted. The narrative provided here allows the reader to see the thesis from my world view, to understand what shapes my view of leadership, and to understand the underpinning curiosities that sit within.

Locating myself within the leadership narrative legitimates my personal experience and perspective as valid. My basic assumption is that Māori leadership practice exists, and because I am Māori, I practice Māori leadership and I play a role in supporting others. The evidence of Māori leadership practice is secured in my work history, my credentials, and my achievements. My curiosity is to understand how this is phenomenon is understood. Am I just working in my own bubble, oblivious to the fact that nobody else really cares or recognises what contribution Māori leadership makes to the public sector? This perspective is the core driver and motivation to pursue the answers and seek out new ways of understanding Māori leadership practice.

\section{A Mãori Boy from Rotorua}

My personal reflections of Māori leadership in public administration come from the perspective of an average Māori boy growing up in Rotorua. This Māori boy follows a pathway into public administration totally oblivious to where it would lead him. By the age of 35, having worked in the public sector for most of his working life, with a growing 
family, I reflect and decide, if this is my pathway I had better aim to be the best public servant I can be. My reflections expose an intriguing journey of mainly highs and not many lows influenced by practitioners of Māori leadership. I had been operating at the interface of government and Māori and found a deep passion for Māori development, whānau, education, and leadership.

\section{Te Arawa e}

This research thesis is guided by Te Arawatanga: a Māori tribal perspective that serves to uphold the mana and rangatiratanga of the researcher and research outcomes. Te Arawatanga also serves to 'manaaki i te kaupapa' and 'manaaki i te tangata' - to take care of the research topic and research participants. Te Arawatanga ensures the validity and authenticity of this research thesis from a Māori perspective.

\section{Ko te whakaariki ko te whakaariki \\ Tukua mai kia piri \\ Tukua mai kia tata}

Kia eke mai ki runga i te paepae poto

A Houmaitāwhiti

According to Macfarlane, Webber, Cookson-Cox, \& McRae (2014), Te Arawatanga as a research framework recognises and validates tribally centered research based on whakapapa identity, thereby providing a relevant kaupapa Māori frame for Te Arawa researchers who undertake research in different contexts. Te Arawa whakapapa identity concerns the relationship between the researcher and tribal connections and, in so doing, positions mātauranga Te Arawa as critical to the Te Arawa world view on leadership and its relationship with the world, including the Crown. Furthermore, Te Arawatanga speaks to the identity and mana of the researcher, locating the researcher in a culturally safe place to undertake this research. My Te Arawa whakapapa inspires me towards the field of leadership. The feats and mischievousness of Tamatekapua, the travels and curiosity of Ihenga, the strength and courage of Rangitihi and the mana bestowed upon Tühourangi suggest that as a descendant of Te Arawa such characteristics are inherent in my leadership capacity. 
Te Arawa refers to the confederation of tribes who descend from celestial beings Pūhaorangi and Te Kuraimonoa, who begat Ohomairangi. The eponymous ancestor, Tamatekapua, travelled from Hawaiiki to Aotearoa, and after much mischief and adventure, finally landed at Maketū. Te Arawa landscapes, geographical features, and related tribal histories create key narratives of Te Arawa and the elements of Te Arawa kawa, tikanga, and kōrero passed down through the generations in whaikōrero, tauparapara, whakataukī, pepeha, haka, and waiata mōteatea.

Ko te kei o te waka kei Maketū

Ko te tauihu e takoto nei kei te putake o Tongariro

Mai Maketū ki Tongariro

Ko Te Arawa tōku waka

The stern of the waka rests at Maketu

The bow of the waka rests at the base of Tongariro

From Maketu to Tongariro

My waka is Te Arawa

This body of tribal knowledge references a tribal framework and perspective of traditional rangatira leadership. Immediately, this stance indicates Māori perspectives of leadership are derived from knowledge sources not previously accessed by other researchers of public sector leadership. These elements present a Te Arawa view of the world which is exercised in the relationships between other tribes and manuhiri.

In relation to engagement with the Crown, there is no better demonstration of this than by Wi Maihi Te Rangikaheke, of Ngāti Rangiwewehi, working with Governor Grey on the preparation of manuscripts which encompassed features of Māori language, genealogies, legends, traditions, contemporary history, political commentary, customs, proverbs, songs, literary commentary, and autobiographical material (Curnow, 2012). My tupuna, Wi Keepa Te Rangipuawhe, who was the Tūhourangi tribal leader at the time of the Tarawera eruption, is another role model tupuna whose sentiments to care for the iwi 
(manaaki tangata) were paramount in his time of chieftainship. I have observed and worked with hundreds of Māori in the public sector, many of whom have been role models and mentors to me, each reflective of their whakapapa connections. This thesis is inspired by my experiences as Te Arawa and my connections to others. The following tauparapara emphasises the connection to Te Arawa waka:

\author{
Unuhia Unuhia \\ Ko te pou mua ko te pou roto \\ Ko te pou he atua rangi mamao \\ Heke heke iho i o ara \\ Takiki te ara o Ngātoro \\ He ara whano ki te pō \\ Te pō nui te pō roa te pō matirerau \\ He pō whai ariki \\ Ko taku waka ko Te Arawa \\ Ka ngahue ki te parata \\ Whano whano oi oi te toki \\ Haumi e, hui e, tāiki e
}

The tauparapara was recited many times by the late Tūhourangi-Ngāti Wāhiao leader and orator Mauriora Kingi, who was also a member of the NZQA's Ngā Kaitūhono at the time of his passing. Integrating the lived experience of Mauriora Kingi into this research reflects the importance of tribal Māori perspectives and wairuatanga (spiritual elements) that guide and protect the wellbeing of us all. The Māori narrative exposes the interrelationships among people and land as powerful tools for discovery, exploration, and evaluation of the issues and contexts for Māori leadership.

The significance of Mauriora Kingi and this karakia to the concept of leadership practice emphasise the relational aspect between waka identity, traversing the dangers and risks of travelling into the unknown, and the inter-connectedness of wairuatanga and concepts of tapu, ihi (power), wehi (awesome) wana (inspiration), surviving through compassion, faith, and determination. For Mauriora Kingi, Māori leadership practices included the 
actions, thoughts, and predispositions that locate mātauranga Māori (loosely defined as Māori knowledge) as central to the experience - he would describe this as 'manaaki'.

My whakapapa traverses from Ohomairangi through to Rangitihi - who would bear eight children, known as Ngā Pūmanawa e Waru o Te Arawa (The Eight Heartbeats of Te Arawa). Rangitihi became the chief and leader of Ngāti Ohomairangi. He was a great fisherman and a strategist in battle. He was a remarkable man (Ngaropo, 2015, p.1):

It is said on one occasion, while Rangitihi was leading a war party, he had his head split open by an enemy warrior. The rest of his force were stricken by this turn of events, but Rangitihi was equal to the situation and called for some Akatea, a climbing plant used for tying palisades, to be brought to him. With his, he bound his split head, and then he rallied his people and led them to victory.

This incident is still referred to in the proverb:

Rangitihi whakahirahira i takaia te upoko ki te akatea. Ehara ma te aitanga a Tiki' Rangitihi the proud and hard-headed one, whose head was bound with akatea. He is a descendant of Tiki.

(Ngaropo, 2015, p.2)

There are further stories about Rangitihi, who married Papawharanui and begat Tūhourangi. He was the youngest of eight siblings. As Tūhourangi grew it was obvious he had the leadership skills and qualities of his father Rangitihi. However, the three senior wives of Rangitihi and also his older brothers did not treat him too kindly. In fact, every morning after they finished their meal Tūhourangi was given left-over food which had become cold, and his brothers called him Tūhourangi kai mataotao - Tūhourangi eater of cold food. The story unfolds with Rangitihi making it clear who the favourite son was (Ngaropo, 2015, p.2).

Whakapapa 1 shows my direct whakapapa lineage from Ohomairangi to Rangitihi, and then from to Tūhourangi through to me. This whakapapa shows my connection to Wi Keepa Te Rangipuawhe, paramount chief of Tūhourangi, through my great-grandfather 
Renati, grandmother Ruiha, and mother Lydia. According to historian Angela Ballara, 'Mita Taupopoki considered the mana over the island (Motutawa), derived from Wāhiao, passed to Tūohonoa, from him to Pakakī, from him to others, and in the late nineteenth century the heir of these chiefs was Wì Keepa Te Rangipuawhe who is the representative of these mana, whose voice is obeyed by the people and whose influence protects the land.' (Ballara, 1998, p. 213).

\section{Whakapapa 1}

Ohomairangi
Ruamuturangi
Taunga
Mawake
Uruika
Rangitapu
Atuamatua
Houmaitawhiti
$\begin{array}{ll}\text { Rangitihi } & \\ \text { TŪHOURANGI=Rakeitāhaenui } & \text { Taketakehikuroa } \\ & \text { Tuteamutu } \\ & \text { Rangiwewehi } 1 \\ & \text { Tuteapututarutaru } \\ & \text { Puraho } \\ & \text { Te Pipi o te rangi } \\ & \text { Te Rangipuawhe } \\ & \text { Takatu o te rangi } \\ & \text { Te Whatu o te rangi } \\ & \text { Te Rangikaingahuhu } \\ & \text { Nawaina } \\ & \text { Te Rangipuawhe } \\ & \text { Wi Keepa Te Rangipuawe } \\ & \text { Te Uruhi Mita Maika Te Rangipūawhe=Te Hiahianui Te Amohau } \\ & \text { Renati Mita Maika=Manurau Wepiha } \\ & \text { Ruiha Rangimahuta Renati=Taituha Rota } \\ & \text { Lydia Rota=John Douglas Bean } \\ & \text { Daryn Bean }\end{array}$

(Renati, P, 2017, p.6)

Whakapapa 2, set out below, is relevant to this research as it shows the whakapapa of Manurau Wepiha, my great-grandmother. I never had the privilege to meet her but to me she represents the quality of unity and care. Through her marriage to Renati Te Rangipuawhe Maika in 1905 held at Ohinemutu she was able to unite the Te Arawa tribes of Tūhourangi, Ngāti Whakaue, and Tapuika-Ngāti Moko. This has shaped my perspective 
that concepts of kotahitanga, whanaungatanga, and manaakitanga are important elements that guide how traditional Māori leadership occurs.

\section{Whakapapa 2}

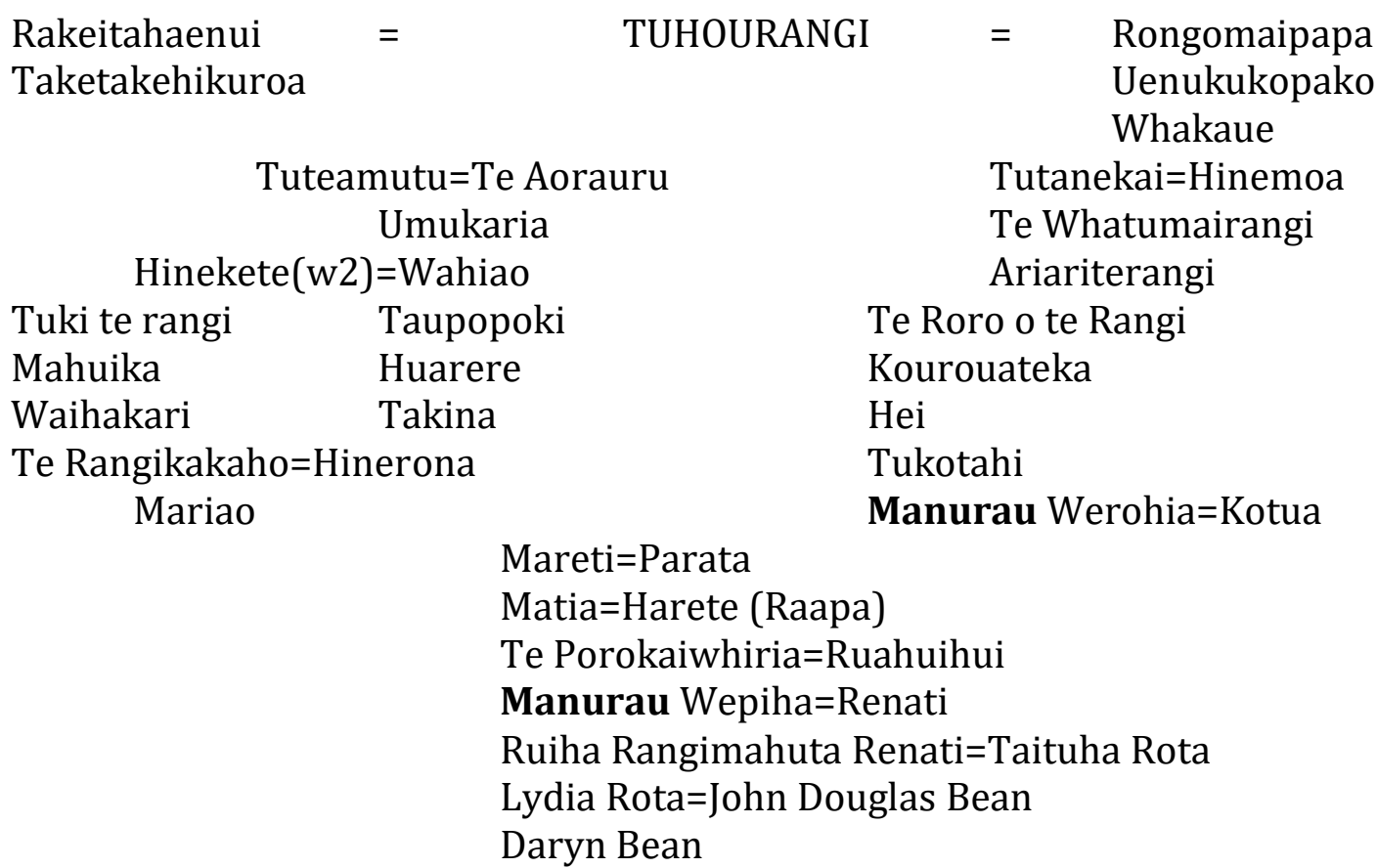

Whakapapa, tribal and customary leadership, positions my perspective as inherent in my being who I am. The key point concerning whakapapa is whilst I am privileged with my Te Arawa whakapapa, other Māori who work in the public sector are also privileged by theirs. I draw strength and courage through whakapapa, and I am confident others draw strength from theirs. This assumption also shapes my view about the innate and intuitive leadership strength I have observed Māori working in the public sector hold. Strength, courage, humility, and care are derived characteristics and attributes, and I am curious to confirm whether my assumption is right, that it comes from whakapapa. So, whilst this thesis positions Te Arawatanga as highly relevant to me as the Māori researcher, I say to other Māori public servants that whakapapa, whatever it may be, is relevant.

\section{Whānau Upbringing}

Whilst my whakapapa to Te Arawa is very important to me, I am equally proud of my Pākehā side, the Bean family, and the 50 years of association the Bean family has with Rotorua. In 1956, Jack and Marjorie Bean (née McPherson) moved from Gisborne to Rotorua. The main reason for moving was because our nana suffered from arthritis and 
chronic asthma. Rotorua, with its thermal wonders, was the perfect place to live. My dad, Doug, found Rotorua to be a great place to live. He enjoyed rugby; going to the dances at Tama, where he met my mother, a nurse; and later on, family life. After Mum and Dad had started going out together, he met my koro, Taituha Rota. Koro Taituha is Tūhourangi, Ngāti Umutahi, and Ngāti Rangitihi from Matata. They did not get on that well initially. Koro would say 'what's my girl doing with that Pākehā fulla?' Dad tells me it worked out fine, and Dad enjoyed socialising with Mum's sisters and his brothers-in-law.

Sunset Road, Rotorua, is where our family unit grew up. Mum, Dad, and my five sisters: Frances, Sheree, Pania, Liana, and Margaret. I remember going to Sunset Primary School. I have fond memories of playing on go-karts and having a pie and two doughnuts for lunch. I remember having a fight in the schoolyard and playing the butler in the school play, The Sound of Music. I remember walking to school under the maunga Ngongotaha fearing it might erupt. Frances was the eldest of the family, Sheree, then me, Pania, Liana, and the baby of the family, Margaret. Margaret stayed with my Aunty Maude in Ponsonby for a while. I can not remember for how long it was. She soon came back, and we grew up together. It was a simple life growing up. One day I remember finding out we were halfcaste!

We used to go to Mount Maunganui for holidays to see our aunties, cousins, and koro. Our koro worked at the wharf. He drank a lot of Coke, and did not talk much. According to my Aunty Billy (her real name was Ivy), he was a good father. She told me Koro and our nan, Ruiha, were an arranged marriage (he mea taumau), and I can now see why in the strength of our whakapapa. I remember getting lost at the beach in Mount Maunganui. The police dropped me off to my aunties, and they were having a feed of pipi. They laughed. Nobody was overly concerned. I remember my aunties loved playing cards. And the smell of fried bread ... it was delicious with butter and jam.

Dad worked for Farmers Trading, and when I was nine years old we moved to Otorohanga first, then Te Kuiti, then Taupō. Those were good days growing up: hanging out with farmer boys, shearing families. It was here that I found my love for rugby. I remember learning how to play. I could set up tries, and it was good fun. Playing for the Maniapoto rep team was a highlight. I remember this feeling of being proud. Also, my dad was a rugby 
referee, and I was proud of that, too. Taupō was my first experience of Māori culture at school. I remember Mrs Wall, and she told us to take our shoes off when we walked into our class. We would play stick games to the song 'E Papa Waiari'.

\section{Early Years}

Leaving Rotorua Boys High School in 1983 at 18 years old was not a planned move. I had two years in the sixth form, and I would have probably gone back for the seventh-form year. But I was lucky. My first XV rugby coach knew I was not an academic type who would automatically choose to go to university, or probably not the type for manual work, either. One day he came to me and asked if I wanted to work at the Department of Labour. I had no idea what the Department of Labour was! But I said yes, of course. I started as an industrial clerk, providing employers and workers information on award wages and conditions and doing administration work for the factory inspectorate. By 1986, I was an employment clerk, and as part of my job I had to travel from Rotorua to Murupara every Tuesday morning. An office was set up in a house on the corner opposite the Murupara shopping centre. I would sit in the office all day. The people who were registered as unemployed were required to come and report to me and they would sign an ES 38 and an ES 39, and by doing so they would be paid the dole on Thursday. If they did not report in, their dole would be cut. As a young man, I felt a huge responsibility.

This situation was a result of the re-structuring of the forestry industry in the mideighties and the region having suffered huge job losses. The economic downturn had really hit communities like Murupara and Minginui hard. The unemployment line was huge. Rain or sunshine, they would line up. They were mostly Māori. I learned all the whānau names in the community, and I remembered their faces. I grew attached to their plight and wanted to help. I began to feel this innate sense of wanting to make a difference for the community, whānau, and iwi. I figured there had to be something better for them than to line up to get the dole!

The Department of Labour was a great place to work in those days. I met people who I would never otherwise meet - Parekura Horomia, Joe Hakaraia, Steve Young, John Bishara, Ben Dalton, Miria Hohaia, Martin Cooper, Amokura Panoho, Dave Thompson, Hona Manuel, Richard Brooking, Evan Nathan, Wally Tangohau, and many others. The 
chief of Tūhourangi, Rangipuawhe Maika, who is also my great-uncle, had returned from Wellington to be the district superintendent of the Department of Labour in Rotorua. I was amazed I was in his company. In my mind they were leaders, Māori leaders. They worked for the Government. They were all working in Māori communities during years when economic policies disrupted the flow of Māori community life. These were formative years, and I learned how to do things. I learned a simple mihi and the structure of whaikōrero. I learned how to facilitate planning hui and wānanga. I learned how to get funding applications approved. I learned how to engage with people and how to bring people together. This group of people would be mentors, role models, people I would look to for guidance.

I used to think, 'who am I to be giving Māori organisations, gangs and local trusts advice on how to set up a group or community enterprise and how to obtain government funding?' It was my job, and I was learning from others, but I had no credentials. I remember going to a wānanga in Ohinemutu that Parekura had set up. Parekura would go around the countryside talking to Māori public servants. Famously, he would tell us he was the most senior Māori public servant in the country. He had a great vision for Māori communities and saw employment, education, and enterprise as the solution. After dinner, he pulled me aside and we went for a walk through the Ohinemutu village. He told me it was time for me to go to university. Parekura must have seen something in me. He was prepared to back me!

He was right. I had to step out of my comfort zone and get over the Koutu Bridge (so to speak). My wife, Debbie, and I and our young whānau left Rotorua and we started a new journey in Auckland, where I worked for the Community Employment Group and attended Massey University in Albany to do my business degree. Upon graduating with my degree, I joined Trade New Zealand in the Māori Enterprise Team and worked with Māori exporters.

I feel privileged in my experience of the public sector. As a young Māori male from Te Arawa, I saw from an early age there was a career pathway and an opportunity to make a difference for whānau. People like Rangipuawhe Maika and Parekura Horomia had already paved the way. There were others following closely in their footsteps and 
creating their own pathway. Education became my ticket to pursuing a professional career in the public sector. Building networks became the critical way to progress and be supported through the system. My attachment to home and to my whānau (Debbie and the children, Mum, Dad, Debbie's mum and dad and sister Sharon, and my sisters and brothers-in-law, nieces, and nephews) and connection to Te Arawa were instrumental in giving me a strength of place, identity, and purpose. The influence of Parekura Horomia was quite profound. I think he knew it, too. He insisted on my pursuing qualifications. I think Parekura must have seen something in me. My intuition is, if anything, I've got to do for others what he has done for me.

In my personal experience, I recall the time when Māori public servants would be the sales force for the Crown. I interviewed a former colleague who reminded me of this. He said, 'the Crown needed Māori to sell stuff to Māori and Māori public servants on the front-line had relationships, networks and could access the key Māori leaders and tribal power-brokers' (research participant). Government agencies pursued various models using Māori units, such as within the State Services Commission and the Department of Labour, as a way for agencies to build relationships with iwi, Māori providers, exporters, and iwi entities. There were 'lolly scrambles' (referring to funding), and Māori entities would access programmes and capacity-building funding as part of the devolution to iwi process. Closing the gaps and capacity-building policies dominated Māori development, and Māori officials were caught between the need to deliver to Māori and to ensure accountability to government.

Parekura Horomia would remind Māori public servants to 'know who you are and where you are from'. He would then say 'go and find out what needs to be done and be helpful'. The Community Employment Group would help to fund the three 'E's - employment, enterprise, and education - through programmes such as mahi-ā-iwi, Enterprise development, and Sportworks. The job involved working with rūnanga, trusts, local authorities, gangs, and community enterprises on projects - bringing groups together, brainstorming, developing plans, and preparing funding applications. We used our nous, our skills, and the networks available to us. Sport, kapa haka, Māori land use, marae development, and other kaupapa Māori interests were used as a platform to get Māori living below the poverty line into positive activity and employment. One former colleague 
said, 'in our region, employment was the big dream'. There was no technology (besides brick phones), and certainly data and evidence, and even mātauranga Māori, were not in our everyday language back then. We were learning about inputs, outputs and outcomes, and monitoring, courtesy of the Public Finance Act (1989) and the doctrine of managing for outcomes. The impact of Parekura Horomia was evident when he established a scholarship programme for Māori in the Community Employment Group to go to university. A former colleague commented, 'In those days, I didn't know anybody who had an MBA, when I told people they said "what is that, some kind of sports programme?"' (research participant).

It would make a big difference for Māori who graduated, and they would go on to manage organisations and large budgets and negotiate and mediate in a range of forums. For all the positive contributions to Māori development and community projects around the country, Māori public servants still operated on the tightrope between the two worlds. 'There was always a danger: one wrong move, you're on the front page and it's good-bye' (research participant). For the mainstream public service it seemed like it was all a mystery, and politicians and media would exploit the inadequacies of the system and castigate individuals for headline news.

Māori public servants were living and experiencing what Māori commonly referred to as 'walking in two worlds'. Māori public servants had an inherent desire to support iwi, community, and Māori aspirations. They would advocate and 'pitch' on behalf of iwi or the provider, as if they were the iwi or provider. As I interviewed participants, they reflected upon different situations, and recalled, 'some would have this "me against the world thing" and "say stupid things and make dumb decisions"'. Some would forget who they worked for and would defend iwi rather than defend the Crown.

This gave an impression that Māori were a risk inside the system. Māori were cast as outriders who would challenge the mainstream and seek to maximise advantages for the group or iwi they were affiliated with. This casting of Māori public servants did not serve Māori in the public sector well; and this pervading perception of Māori, by non-Māori, entrenched a natural bias against Māori. The context for this thesis would begin to 
emerge, and the notion that, to survive in the two worlds of Māori and Westminster systems, as Māori, required Māori officials to lead and to practice leadership.

These are my reflections as a Māori boy from Rotorua who had little inkling of what the future would hold for him. Yet despite this, I held a deep desire in myself to pursue the challenges that lay ahead. Where did this sense of self-belief come from? What is the source of inspiration? What has moved me, this Māori boy from Rotorua, to pursue a study of Māori leadership practice, this phase of searching for leadership and what constitutes Māori leadership?

\section{The NZQA and being an insider researcher}

A key feature of this thesis is the positon of the NZQA as a research site. My experience as Deputy Chief Executive (DCE) Māori working at the NZQA has helped to shape and develop my perspectives of Māori leadership practice. I acknowledge my voice is but one voice that can express the NZQA Māori narrative; there are other Māori staff, who each have their perspective and different experiences. When I joined the NZQA in 2009 there were 17 Māori staff employed; now in 2017 there are 56: 16 percent of the total NZQA workforce, slightly above the public-sector median. In 2009, the first Māori strategy was being initiated. Since this time, the NZQA has experienced 10 years of successful implementation of Māori strategies. When I joined the NZQA, Māoridom were grumpy with the NZQA. The relationship has substantively changed and is now, mostly, very positive. My gratitude goes to the Executive team and Office of the DCE Māori and key Māori staff who worked hard to create an environment for Māori staff to be Māori, for kaupapa Māori to be recognised, and, for te reo me ōna tikanga (the Māori language and culture) to hold a rightful place at the NZQA.

This thesis calls upon deep knowledge and understanding of the Māori transformation at NZQA; relationships with Ngā Kaitūhono; thought leadership on mātauranga Māori; Māori staff perspectives; and implementation of Māori strategies. This role and capacity to work intimately with Māori and influence future directions is a privileged position and one that gives direct insight into the experience of Māori leadership in a government agency. 
As an insider researcher and practitioner, Costley, Elliott, \& Gibbs (2010) determines that 'when looking at questionable relationships between the research and participants the most salient issue is power', and that reminds us that the politics of the research strategy needs to be carefully considered (p. 38). This means that extreme care is required to manage conflict among stakeholders, unequal power relations, or unethical activity. Costley et al. (2010) highlights the ethic of care. Noddings' (1984) theorising of 'caring' is a three-phased process consisting of engrossment, empathy, and the disposition to act on behalf of another (p. 43). Involving rather than observational is an appropriate approach for Māori research, and the idea that 'caring carries a moral obligation' is also relevant (p. 44). Ultimately, caring is about the integrity of the researcher. In my analysis of caring, to care is to design and plan the research strategy carefully; to ensure clarity of purpose, clarity of the research role, and clarity of the research stance, the research agenda and methodology. The researcher view focuses on caring to eliminate role ambiguity, conflict, and the potential for exploitation (p. 44). My perspective situates the notion of care, or, in Māori terms, 'manaakitanga', as critical at the interface of Māori leadership and the public sector.

\section{Reflective Thoughts}

Employment in the public sector has dominated my working life. My personal leadership practice is shaped by my early years and the roles I've had, the people I've looked up to, and the support I've received. As a late starter to education, I graduated with a business degree at the age of 31. My heart has always been in Māori development. My experience working for Parekura Horomia (and others) at the Community Employment Group and later Te Puni Kōkiri in Te Tai Tokerau would have more of an influence on my whānau than I could have imagined. When my whānau made the move to Wellington and I joined the NZQA as DCE Māori, I had not contemplated that I would embark upon doctoral study. I would receive unbelievable support from Dr Karen Poutasi. As Māori, working in public administration, enjoying living as whānau Māori, my lived experience is evident in this thesis.

I make assumptions about Māori leadership practice in government agencies. Whānau, whakapapa connections to Te Arawa, work experiences, and mentors have embedded a leadership practice philosophy into the way I see the world. These underpinnings 
permeate into practice within my own reality. I find there are mis-conceptions and misinterpretations about the role, place, and legitimacy of Māori leadership practice. I seriously wonder why it is still an area of public sector leadership research that has not been given its dues and why it has not attracted academic attention when the Crown and Māori have been in a relationship (of sorts) for over 175 years. The concern is transformed into a kaupapa - a topic, subject, purpose, underpinned by a Māori philosophy or theory that Māori leadership in the public sector is a process of collectivism and strategy, underpinned by tikanga practices that bring forth multiple elements and concepts.

Having positioned my curiosity and inquiry into a perspective of kaupapa Māori, I still remain extremely cautious and apprehensive about applying kaupapa Māori theory within a kāwanatanga space. This thesis argues Smith's (1997) transformational praxis element exists within kāwanatanga spaces. Māori public servants express critical voices and practise leadership to challenge and reframe the bureaucratic paradigm. The Māori presence in kāwanatanga contests underlying bias. Without a kaupapa Māori framework, Māori public servants working inside kāwanatanga are left vulnerable, with their mana, rangatiratanga, and connections to iwi, hapū, and whānau compromised.

The mantra 'for Māori by Māori' is a mantra that I am unsure about in this context (BevanBrown, 1998). This research is by Māori, and the research design is developed to ensure the integrity kaupapa Māori theory proponents would expect. However, it is a kāwanatanga space, and therein lies the dilemma. It is for Māori, in the sense that better informed public-sector leadership leads to better Māori outcomes and public value. In my mind, I am thankful for my Te Arawa whakapapa and confident that my research stance can defend challenges. I am trusting my instinct that carving a space for kaupapa Māori theory and Māori leadership practice into kāwanatanga consciousness is indeed kaupapa Māori-inspired leadership practice. The research process itself raises a critical awareness about another way, another view, and another theory of leadership. 


\section{Māori Leadership Practice as a Research Topic}

There are many concerns Māori have about the role and place of Māori leadership in government agencies. These are addressed in the introduction chapter to set a context for the challenges this study faces.

\section{Māori Leadership Studies}

There were dilemmas and challenges with this research topic that had to be tackled. Linda Smith (2005) aptly described Māori research as being on tricky ground. First, this thesis about Māori leadership practice is undertaken within a kaupapa Māori research framework, yet is located within a Pākehā institution: the School of Government at the University of Victoria (Wellington) and within the Doctor of Government (D Gov) programme. It may seem more appropriate to locate this thesis in fields of Māori studies, or mātauranga Māori, or at wānanga Māori (Māori tertiary institutions). However, the context of this study, kāwanatanga or public administration, is critical, particularly in how the university and leadership academies contribute to the scholarship about the role and place of Māori leadership in the New Zealand public sector and the twenty-first-century post-Treaty of Waitangi settlement context. Working on this thesis, as Māori, reflects the importance of Māori leadership studies and kaupapa Māori perspectives to other fields of study within public administration. Also, it reflects the challenge of research at the interface integrating the Māori and Westminster dichotomy at methodological, ethical, and policy levels without compromising the integrity of either (Durie, 2004c, p. 2)

The journey of this thesis began in 2013 with my enrolment in the D Gov programme. Eight senior public servants joined the D Gov cohort and participated in a structured postgraduate programme consisting of group discussions, readings, academic supervision, peer support, and assignments. The D Gov approach aimed to support senior public servants to complete a doctorate whilst they were still in employment.

Despite the cohort's fascination with the research topic and positive encouragement by academic staff and supervisors, I felt there was a disconnection with how kaupapa Māori research is positioned and acknowledged within a university based on Western tradition and philosophies. With Pākehā academics and supervisors, who I admire greatly, and although they admittedly do not deeply or intuitively understand the Māori world, the 
notion prevailed that, in my perception, the Western institution laid claim to some level of academic superiority over experiential and lived Māori knowledge. Thankfully my supervisors sensed the importance of the questions that I was asking. They knew deep down that this is an area that has not been addressed and appreciated the fact that someone like myself was interested in examining this more closely.

The challenge to explain and articulate the topic felt like I was continually being judged. I had to triangulate Māori knowledge with other forms of knowledge or theories to validate Māori knowledge and therefore the credibility of the research. This created significant self-doubt as to whether this research topic was as valid as and equal to other $\mathrm{PhD}$ studies. This also placed both the research and the researcher into the unenviable position of needing to find a sense of place. The research was inspired by personal journey, whānau, and a personal deep sense of connection to my tribal base, Te Arawa, and the people who have invested in me. This guided me to the conclusion that my life's work is worthy, and is a contribution to a much bigger goal. Again, the sense was to be courageous and step into this space and be self-determining.

As an academic researcher, I was traversing new landscapes. The priority, however, was that I wanted to feel confident and comfortable that my values were not compromised in this research process. I needed to create a research framework that I could sustain, and one that could sustain me. The research framework needed to reflect at its core 'who I am?', blending my personal lived experience, public sector career, NZQA experience, postgraduate education, and whānau aspirations. I was highly motivated and curious to contribute to leadership knowledge and research. The challenge became a process of reciprocal action, firstly to enable people to share their knowledge and experience, and also to give something back to those who are also on a leadership journey.

In the end, this thesis provides two elements that offer an original contribution to the knowledge. Firstly, it contributes knowledge of how to consider a research methodology based on kaupapa Māori theory, as a Māori public servant operating within the kāwanatanga paradigm - that is, within a context antithetical to Māori. Other Māori public servants as researchers may benefit from this new knowledge and experience and contribution to kaupapa Māori research. Secondly, the thesis examines Māori leadership 
as a practice framework that, by virtue of its experiential underpinnings, provides legitimacy to the role of Māori public servants in public administration. The research can be said to rest on experiential evidence that is qualified by the background, experiences, and circumstances of Māori officials spanning the last two decades. Academics, public sector agencies, and iwi Māori may refer to the descriptions and elaborations of Māori leadership concepts knowing the source is authentic and based on lived Māori experience.

\section{Statement about the use of te reo Māori (the Māori language)}

This is a thesis written in the English language. However, the use of te reo Māori is a key feature as it is appropriate and relevant for the thesis topic. My approach is to promote te reo Māori and ensure it is accessible to readers, Māori and non-Māori alike. The use of te reo Māori helps readers to understand Māori concepts. My personal journey with te reo Māori, like many others, is a life-long learning journey. You will notice that the use of te reo Māori reflects the stage of progression in my reo journey. This approach was encouraged and supported by my academic supervisors.

The way I use te reo Māori is to apply it as naturally as possible, as if I were having an English language conversation and I incorporate te reo Māori words into the sentence. Where I use te reo Māori words, terms or phrases for the first time, I will provide an English translation in brackets. In some instances, te reo Māori has a slightly different meaning depending on the context. In these situations, I will provide an English translation in brackets that is appropriate for that context. For known or repeatedly used words, an English translation is not provided. A glossary of terms is also not provided as I have found flipping pages backward and forward detracts from the flow of reading the thesis. One suggestion is to have a dictionary handy or to use www.māoridictionary.co.nz, which is available globally online.

\section{Thesis Overview}

This thesis is an inductive qualitative study using kaupapa Māori theory and methods. The distinct contribution of this thesis brings together kaupapa and mātauranga Māori epistemologies with the notion of L-A-P (Raelin, 2011), to create an alternate view of 
public sector leadership as both theory and praxis. The thesis acknowledges that the term Māori is homogenising and belies the heterogeneity of the Māori experience, and that readers may have their own tribal context and lived experience. This thesis seeks to enable readers to relate their personal experience and iwi specificities to the analysis and findings, so they too may advance their Māori leadership narrative.

Chapter One explains who I am to be doing a thesis on this topic. The thesis is explored from the perspective of a boy from Rotorua who has worked in the public sector from the age of 18 years and who has experienced and observed Māori leadership practice throughout a career spanning some 30 years. The chapter is a personal reflection that covers my upbringing, whānau, whakapapa connections to Te Arawa, and early influencers and experiences. This chapter provides a personal perspective of Māori leadership practice and introduces concepts that I have experienced within the context of public administration. Having articulated my perspective and curiosity, this chapter charts the broader context of Māori leadership in the public sector, provides background to the issues and outlines how the issues will be addressed.

Chapter Two provides a focused review of literature to highlight critical literary bodies relevant for this study. Māori leadership theoretical perspectives relevant to the public sector are firmly anchored in the Treaty of Waitangi/Te Tiriti o Waitangi. Setting out a description of a two-worlds framework places Pākehā and Māori world views of critical concepts at opposite ends of a spectrum. For example, concepts such as rangatiratanga (translated as chieftainship, ownership, self-determination) and kāwanatanga (translated as governorship, government) represent a fundamental clash in values and world views.

Public sector leadership literature is examined with two particular foci on leadership-as practice (Raelin, 2011) and leadersip in context (Crosby \& Bryson, 2005) and locates the study firmly in the field of public sector leadership practice as opposed to a general study of leadership, leaders, or Māori leaders. The mainstream literature is weak in describing Māori leadership as a practice and tends to focus on the exploits of individual leaders, placing leadership labels on them, such as transformational, authentic, or academic (eg, Katene, 2013). This chapter establishes the rationale and finds a legitimate space for a 
thesis on Māori leadership practice within the context of public sector leadership and public administration. This chapter positions the study within kaupapa Māori leadership practice, rather than Western leadership practice.

Chapter Three establishes the rationale for kaupapa Māori research methodologies and explains how concepts such as whakapapa identity, whakataukī, and wānanga are used to explore rich and deep insights within the distinctive Māori leadership narrative. The chapter emphasises the need for a 'unique methodology' and decisions for using an innovative, inductive-qualitative research approach, specifically using a combination of wānanga and interviews, case study (Johnson \& Christensen, 2008), and narrative analysis (Ospina \& Dodge, 2005) in the research design. The rationale for choosing qualitative research methods approach aligns with kaupapa Māori theory and the purposes of this thesis.

Chapter Four sets out the research findings in detail. The chapter presents Māori leadership practice within a broad framework of experience where conflict, confusion, and compromise are normalised as lived reality. The research argues that despite pockets of resistance and frustration, Māori officials are attuned to the nuance of two worlds and in practice are focused on making a difference for Māori and achieving positive outcomes for all. This narrative is informed by listening to the voices of Māori experience through wānanga and in-depth interviews with 34 research participants. The analysis of transcripts, case studies, key findings, and concepts identifies and describes how Māori leadership practices have emerged from this context.

Chapter Five presents the organisational case study which is the NZQA. This case study outlines the NZQA's role, context, relationship with Māori, and experience implementing Māori strategies and initiatives between 2007 and 2017. This situates the NZQA case within the broader context of Crown-Māori relationships and provides an example of how government agencies enact Māori leadership practice. This description is informed by the researcher's own understandings and deep experience as the senior Māori executive at NZQA from 2009 to 2017. This is supported by interviews with the NZQA Chief Executive, senior Māori staff at the NZQA, and wānanga with the NZQA Māori staff network and Ngā Kaitūhono (the strategic NZQA Māori governance board). This case 
study is informed by literature and organisational documents.

Chapter Six introduces takapau wharanui (literally, great mat) as a whakapapa-based analytical framework to set out the discussion of the key findings emerging from the data. The first section discusses the summary of findings and key themes. This is followed by a discussion of kaupapa Māori perspectives of leadership. A section is provided to discuss the similarities and differences between the voices of lived experience data and the organisational case study data. A synthesis of the key findings with the literature gives a summary of the key Māori leadership practice concepts and elements to inform an emerging theoretical framework of Māori leadership practice.

Chapter Seven sets out the Manurau framework of leadership and describes Māori leadership practice as both strategic and collective leadership that is fundamentally based within Māori epistemology (mātauranga Māori). The chapter focuses the discussion on an over-arching framework of Māori L-A-P and the concept of Manurau as a metaphor to differentiate kaupapa Māori perspectives of leadership from other perspectives. Whakataukī are expressed to locate the framework within the wisdom of our ancestors. These over-arching kaupapa Māori theoretical perspectives and practice methods are then discussed for application in public administration.

Chapter Eight provides my concluding statements and reflections on the research process. The chapter outlines the limitations of the research. Discussion of the implications for further research highlights the unique nature of kaupapa Māori research within the context of the public sector. The need for further research areas are identified to build knowledge about how Māori leadership practices can be designed to fit public sector purposes and meet the expectations and aspirations of te ao Māori (the Māori world). Closing statements reiterate the paradigmatic shift towards Māori leadership-aspractice as an appropriate way of looking at leadership in public administration. 


\section{Chapter Two: Literature Review}

\section{Overview}

Global leadership literature is vast and consuming. Yet despite being able to pick up a leadership book through any airport bookshop, Google search, or university library, finding literature on Māori leadership, specifically in the field of public administration, is a task. The search involves scooting around Western leadership and public administration literature trying to find the space where Māori elements of leadership are recognised. It is of little surprise then that there is limited conceptual understanding of Māori leadership, as practice, within a government agency context and from a kaupapa Māori perspective.

This chapter provides a focused review of literature, as opposed to a full literature review, to maximise the key opportunity in this research to explore relevant Māori leadership literary pieces that intersect the field of public administration. The review explores the literature from the perspective of 'seeing through the eyes of Māori' and acknowledges the work of kaupapa Māori scholars and practitioners. To me, this is important, as the New Zealand experience differs from other jurisdictions as the context is within the Treaty of Waitangi, colonial history, and Crown-Māori relationships. Aotearoa New Zealand is unique in this respect as, the thesis argues, the heart of Māori leadership in public administration emerges at this interface. The historical backdrop and goals for a modern New Zealand public service all mix to create a kāwanatanga narrative that draws attention to Māori leadership as the critical nexus to identify and reveal distinctive leadership practices that are regarded as Māori (Durie, 2003; Katene, 2013; Mead et al., 2005; Workman, 1995).

This review attaches Māori leadership alongside the movement of leadership-as-practice (L-A-P) as formulated by Raelin (2011), suggesting the modern cultural context of public administration has moved beyond thinking about leadership as leaders with outstanding personal, charismatic, or transformational skills. The practice elements create a paradigmatic shift whereby Māori leadership can be evaluated based on what, why, and how leadership occurs, rather than who creates the leadership. The review explores relevant Western leadership practice theory, including leadership in public 
administration (Fairholm, 2004); L-A-P (Raelin, 2011); creating public value (Moore, 1995); and leadership in context (Crosby \& Bryson, 2005) to make the link in this thesis to the general field of public sector leadership and public administration.

\section{Navigating the Two Worlds Context}

This thesis argues that Māori leadership in public administration is a phenomenon that straddles two worlds - rangatiratanga (translated as chieftainship, ownership, selfdetermination) and kāwanatanga (translated as governorship, government). The historical relationship is a story of colonisation, politics, and a struggle for power and equality, with the roots firmly anchored in the Treaty of Waitangi/Te Tiriti o Waitangi and its principles. Operating in this context are government officials, both Māori and nonMāori, who create and experience daily enactments of Māori leadership through expressions of kaupapa, tikanga, and modern pūmanawa (talents and skill).

The phenomenon of indigenous and Māori public servants who straddle the two worlds of their tūrangawaewae (traditional home base) and their roles as public servants within the government bureaucracy is not new, and is recognised by researchers such as Wilson \& Baker (2012) and Main (2005). Calliou (2005) (cited in Main, 2005) recognises this metaphor and argues the need to weave together traditional principles of leadership and governance with those of modern management. Calliou recognises the debate about the effects that colonisation has had on leadership and the need to overcome this by bringing back traditional values and principles. He does not see the bringing back of these values and principles as trying to achieve 'pristine' forms of leadership; instead, he considers that leaders need to be rooted in their 'culture, traditions, and history' (Main, 2005).

Figure 1 provides an illustration of the two-worlds context that depicts contrasting Pākehā and Māori world views. Beneath every element are deeper meanings, and multiple and differing perspectives. The centre line represents the interface. This is the space where the phenomenon of Māori leadership is located and where bridge-building and balance is needed.

As I was developing my research proposal I reflected on my personal experience and what I have observed over the years. I conceptualised the specific terms that manifest as 
dimensions that represent Pākehā and Māori contexts as opposite sides of the coin. For example, there is tension and debate between the two versions of the Treaty of Waitangi: the English version and the reo Māori version, Te Tiriti o Waitangi. The Māori text is not an exact translation of the English text. The Māori text has a different emphasis. It suggests that the Queen's main promises to Māori were to:

- secure tribal rangatiratanga

- $\quad$ secure Māori land ownership

whereas the preamble to the English version states that the British intentions were to:

- protect Māori interests from the encroaching British settlement

- provide for British settlement

- establish a government to maintain peace and order.

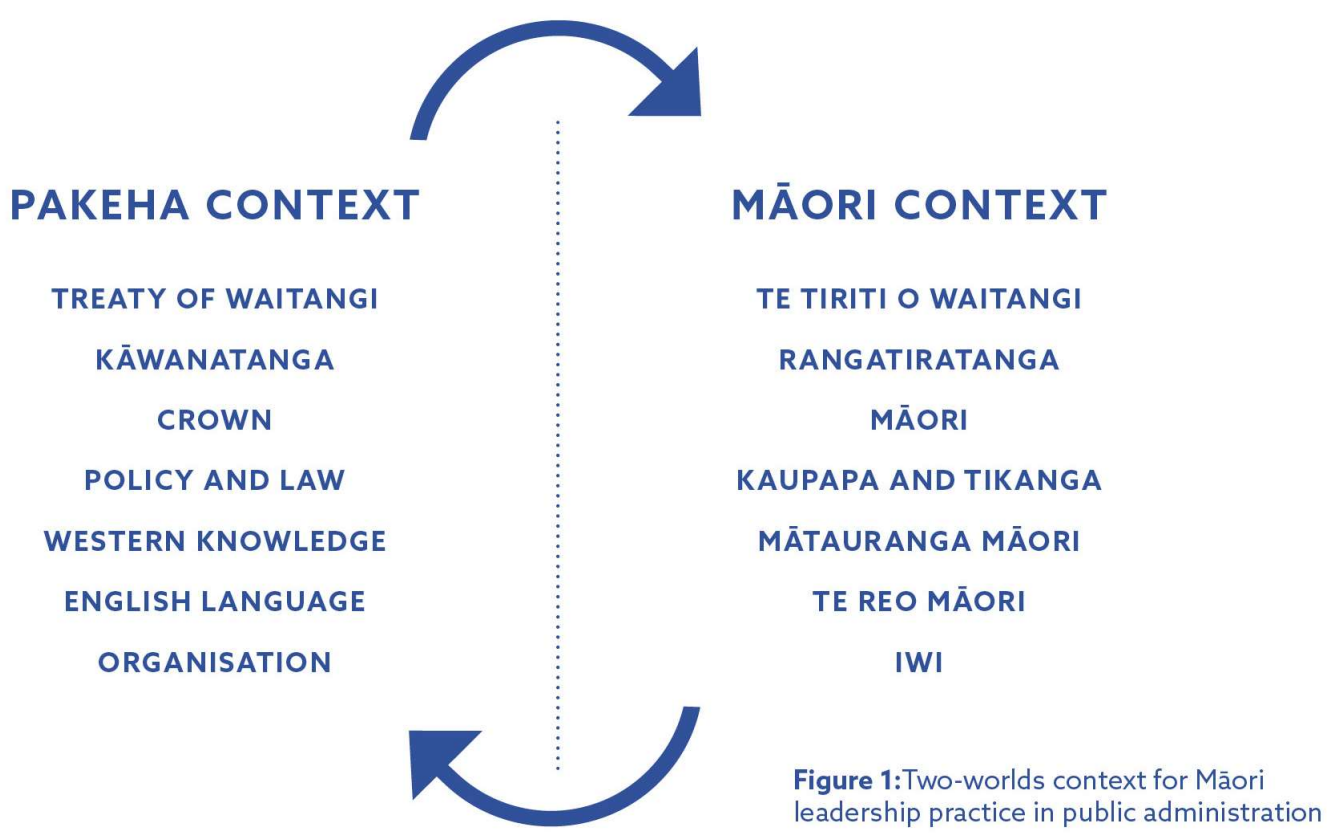

The Waitangi Tribunal is an example of an entity that operates in the two-worlds space. The Treaty of Waitangi Act 1975 requires the Tribunal to 'decide issues raised by the differences between them' (Waitangi Tribunal, 2017b). Similar tensions and debate surround the other concepts. Kāwanatanga is the antithesis of rangatiratanga and conjures emotions of government and dominant colonial power against Māori and their 
rights to lead and live independently from the sovereign state. Crown is a word to describe the totality of government and government power based on Westminster tradition (the Crown). Māori is a word to describe the totality of the Māori people (a word to describe all people who come from Māori tribes of New Zealand). Policy and lawmaking sit within the realm of Westminster systems. Kaupapa and tikanga are the domain of the Māori world. They set rules and regulate behaviour within their specific worlds, but when they interface there is a fundamental clash of values. This leads to the serious debate about knowledge bases and the privilege of Western systems of knowledge over indigenous knowledge systems (mātauranga Māori). This has direct consequences for the privilege of English language over the recognition, use, revitalisation, and sustenance of te reo Māori, as an official language of New Zealand. The final point of tension within the two-worlds frame is the position of government as an organisation relative to the postion of iwi and the unequal power relations that compound issues of rights, interests, and relationships. This thesis does not seek to intellectualise these words, but to get a sense of all the words and associated connotations within each context (Pākehā and Māori) and to gain an understanding of what the totality of that context looks and feels like.

The arrows in the model indicate a circular motion that implies the dynamic and holistic nature of the two-worlds context. All the elements are inter-related and impact on each other. It is within this overall context that the question about the aim of Mãori leadership practice in public administration emerges. Is it to advance Māori interests or is it to advance the interests of all? And who is this leadership for? Is it for the Māori world, or is it for the public sector? Is it for Māori and Pākehā alike?

To answer these questions this thesis locates the two-worlds context within the Māori philosophical frame that is kaupapa Māori. In modern terms, Māori public servants walk in two worlds - Crown and Māori - and have survived, and different situations and environments have either forced them or encouraged them to bring an inherent leadership practice capacity - a practice philosophy of balancing rangatiratanga and kāwanatanga; applying strategic, collective, and cultural elements interwoven into a transforming mission (Smith, 2015). 
This research explores to what extent the phenomenon of two worlds is also a subversive practice - a practice of resistance (Smith, 1997). This is a practice that says, 'If, as Māori public servants, we must live in your kāwanatanga world, we are also going to create a space for ourselves as Māori'. This is a practice of survival as a people, an expression of rangatiratanga within kāwanatanga, and a recognition that Māori officials can hold onto their uniqueness and not have to be the same as everyone else. In a recorded conversation, Hirini Mead (personal communication, 2013) recalled a statement from Sir Apirana Ngata, who said, 'Māori officials are obliged to live in two worlds where they work forty hours a week in the public service and, whilst doing so, leave their culture behind. Only in the weekends can they give their time and minds to their culture, their whānau, hapū and, iwi.' Sir Hirini Mead noted that, 'what he really meant was, it should not be like that. As Māori you should be able to give your mind to your people all of the time'.

Mahuika (2008) picks up on the theme that kaupapa Māori is a theory and practice of active resistance to the continued colonisation of Māori people and culture, and, in many ways, is anti-colonial. This argument, however, is tempered by the notion that kaupapa Māori is not about rejecting Pākehā knowledge. There exists an opportunity to infuse, interwine, integrate, dismantle, reconfigure, and rebuild the model. Mahuika suggests an often-cited whakataukī of Sir Apirana Ngata as a frame for this approach:

\section{E tipu e rea, mō ngā rā o tōu ao}

Ko tō ringa ki ngā rākau a te Pākehā hei ara mō tō tinana Ko tō ngākau ki ngā taonga a ō tūpuna Māori hei tikitiki mō tō mahunga Ko tō wairua ki tō atua, nāna nei ngā mea katoa Grow up and thrive for the days destined to you Your hand to the tools of the Pākehā to provide physical sustenance Your heart to the treasures of your Māori ancestors as a crown for your brow Your soul to your God, to whom all things belong

(Brougham \& Reed, 1999, p. 89) 
This became much quoted as a vision for Māori youth (Higgins \& Meredith, 2011). It is often seen in government publications and heard in government environments as a way to inspire leadership.

\section{The Treaty of Waitangi Principles}

This review does not explicitly examine the histories of the Treaty of Waitangi, iwi, and Crown-Māori relationships, as this is best left to historians and scholars such as Orange (1987), King (2003), Ballara (1998), and Walker (1990), among others; however, the point is made of the significance and relevance of the Treaty of Waitangi in the minds of public servants. To emphasise the point, the thesis focuses on the substantive role of the Waitangi Tribunal to articulate the principles of the Treaty of Waitangi in the context of modern Treaty settlements as being fundamental to building currency and relevance to leadership at the Crown-Māori interface. The Waitangi Tribunal Report (2011) entitled Ko Aotearoa Tènei (also known as the Wai 262 claim report) is the most comprehensive and authoritative report concerning New Zealand law and policy affecting Māori culture and identity. The significance of this report is its relevance to the concerns about mātauranga Māori and taonga tuku iho (treasures handed down) and its explicit descriptions of evidence relating to Crown responsibilities. The Treaty claim was wideranging, but in essence argued that the Crown denied Māori the full exercise of their rangatiratanga (absolute authority) over many aspects of their life (Waitangi Tribunal, 2011, p. 2). The principles of the Treaty of Waitangi are applicable in the study of Māori leadership in the Crown-Māori context because the Treaty provides:

1. the guarantee to actively protect the tino rangatiratanga of iwi and hapū over their taonga katoa all treasures; the Tribunal had previously found that mātauranga Māori was a taonga and therefore subject to the principles of rangatiratanga and active protection (p. 15)

2. the provision for both kāwanatanga and tino rangatiratanga - partnership as an over-arching principle.

A second Waitangi Tribunal (2017a) report, entitled Tü Mai Te Rangi!, on the Crown and disproportionate reoffending rates, is also significant in the context of this study. The 
claimant alleged that the Crown failed to make a long-term commitment to reducing the high rate of Māori reoffending relative to non-Māori (p. ix). This report specified two further relevant Treaty principles:

1. kāwanatanga and rangatiratanga based on a fundamental exchange of kāwanatanga, or the right of the Crown to govern and make laws for the country, in exchange for the right of Māori to exercise tino rangatiratanga over their land, resources, and people (p. 25).

2. the principle of equity, or the obligation of the Crown to act fairly between Māori and non-Māori, derived from the British citizenship rights granted to Māori by article 3 of the Treaty (p.27).

An organisational perspective helps to clarify the position of the principles of the Treaty of Waitangi, and specifically the rangatiranga-kāwanatanga principle within the context of public administration.

The Tü Mai Te Rangi! (2017) report refers to the Te Paparahi o te Raki inquiry, which found that 'the understanding upon which past Treaty/Tiriti principles were based, that Māori ceded sovereignty to the Crown, was wrong'. The report states, 'The Te Raki report concluded that the Bay of Islands and Hokianga rangatira who signed te Tiriti in February 1840 did not through that act cede their sovereignty.' The Tribunal said that by agreeing 'to share power and authority with the Governor', those rangatira agreed to a relationship in which they and the Governor were to be 'equal while having different roles and different spheres of influence'. In relation to this report and its relevance to other fields of public administration, the pertinent issue raised is 'for us to consider the need for government agencies to balance their statutory and Treaty responsibilities'. Government agencies have a Treaty obligation to take reasonable steps to reduce Māori offending, improve Māori health, increase Māori education achievement, and so forth. Agencies must appropriately balance their kāwanatanga responsibility with the ability of Māori to exercise rangatiratanga. The Waitangi Tribunal emphasised in this report that the Treaty principles of equity and active protection are two sides of the same coin, and current inequity between Māori and non-Māori heightens the Crown's obligation to actively protect Māori interests. 
In relation to partnership, the Waitangi Tribunal called for a more thorough exercise of the Treaty partnership between Māori and the Crown. The Department of Corrections said they must work together at 'a high level': 'it must be open to a "bold approach" that embraces a different kind of thinking ... Māori culturally based thinking'. The Department's Māori Director said the issue required a 'national conversation between Māori and the Crown at the highest level'.

The Tü Mai Te Rangi! report provided further evidence that senior Māori officials as leadership practitioners clearly understand their role and sphere of influence in the twoworlds space. The report noted the efforts of the Māori Services team, headed by the Department's Director Māori, and including the Reducing Re-offending by Māori Work Plan 2015-2016 (Waitangi Tribunal, 2017a, pp.79-81). Unfortunately, the report does not explicitly recognise the role of Māori leadership practice, whereas this thesis argues that the work and effort of the Māori Services team is exactly what Māori leadership practice is. The assumption is that an intuition of Māori ways of thinking within agencies exists, and that agencies have a capacity to understand.

In the Tū Mai Te Rangi! report, if not explicitly, showed the Māori Director was instrumental in providing leadership within the Department. However, there were obvious constraints operating within a large department in a tier 3 management role that is responsible to a Deputy Chief Executive or Deputy Secretary. The Māori Director had limited sphere of influence and decision-making in terms of how Māori strategies are developed and implemented and how resources are allocated. Restoring the balance between rangatiratanga and kāwanatanga and pursuing the goal of equity is the work of Māori leadership practice, but so too is traversing the constraints and conflicts that exist within the machinery of government.

Durie (2004c) underscores the significance of the Treaty of Waitangi as a platform for forward development rather than as a vehicle for redress, including the ways in which Māori and the Crown can jointly advance New Zealand's economy and standards of living. The fact that the Waitangi Tribunal is able to provide an opportunity for Māori tribes and claimant groups to research claims, produce evidence, and tell their story, within a 
tikanga and kaupapa Māori framework, suggests focusing on the past and settling claims is one element, but creating futures for the generations to come is paramount. Durie (2004c) highlights moving beyond settlements and a grievance mentality towards the positive intent of planning for the future as critical. The Treaty relationship between Māori and the Crown as premised on the principles of partnership, mutual benefits, and mutual respect is therefore a key platform.

\section{Perspectives of Kāwanatanga}

Kāwanatanga, defined as government, dominion, rule, authority, governorship, or province, represents the space and place of government with all its Westminster traditions, histories, and connotations (Williams, 1992). Most of what is written about kāwanatanga refers to Treaty of Waitangi-based arguments and legal cases, as kāwanatanga concerns the fundamental relationship between Māori and the Crown and the unique obligations that flow from the Treaty of Waitangi (Chen, 2012, p. 57). Chen (2012) refers to articles 1 and 2 of the Treaty of Waitangi as the 'essential bargain' whereby Māori gave the Crown a right of governance, transliterated as kāwanatanga, whereas in the English text, Māori ceded 'sovereignty' - a concept said to have no equivalent in Māori thinking (p. 457). According to Meredith and Higgins (2012), from the outset, the relationship between Māori and the British-installed Government was burdened by cultural misunderstandings and British disregard for Māori custom. The work of Te Rangikaheke, Apirana Ngata, Kara Puketapu, and others has sought to build this bridge between cultures. Unfortunately, as Ranginui Walker highlights:

the impact of colonization on traditional leadership roles and the external forces of

European capitalism, missionaries and British imperialism, impinged upon, and progressively undermined the mana of traditional leaders.

(Walker, 1993)

This statement exemplifies the complexities of Māori working within Westminster structures (Pihama \& Gardiner, 2005). The Māori perspective of kāwanatanga is aligned to Smith's (1997) notion of kaupapa Māori as a resistance strategy through the expression of rangatiratanga. Dr Colin Knox has argued that, as a result of colonisation, Māori suffered a major decline of culture and tikanga in almost every aspect of society. 
He suggests a kaupapa Māori approach to kāwanatanga is aligned with traditional values and tikanga (Tawhai \& Gray-Sharp, 2011, p. 224). Associate Professor Paparangi Reid points out that when Māori tribes ceded kāwanatanga to the Crown they had every right to expect good governance; fair, just, and ethical governance. Reid states that a critical expression of fair, just, and ethical governance is equity. Equity is, therefore, the yardstick with which Māori may assess governance or kāwanatanga (Tawhai \& Gray-Sharp, 2011, pp. 39-40).

Normative theory suggests the relationship between kaupapa Māori theory and kāwanatanga poses assumptions about why and how government ought to think, act, and behave in Māori environments. For example, the government ought to ensure it fulfills its obligations to the Treaty of Waitangi. The government ought to support, revitalise, and sustain te reo Māori as an official language of New Zealand. The first assumption is that government agencies and officials ought to adopt a theoretical disposition to privilege elements that are important to Māori.

As Cribb (2006) points out, the fundamental difference between theories, kaupapa Māori included, is their assumptions about individuals (p.148). The second assumption in relation to governance is that there are 'Māori voices' sitting around the table. It is assumed the 'Māori voice' is mandated and affiliated to whānau, hapū, iwi, or the Māori community. This raises the question about what accountability that Mãori voice has to the Crown, if in fact they are employed by the Crown. Conversely, what obligations does the Crown have to Māori?

Public administration dimensions of policy, law, regulations, and rules assume agency theory as the dominant governance model. Agency theory assumes individuals are rooted in economic rationality whereby the principal (ministers) can hold agents (chief executives) to account for performance and delivery of services (Cribb, 2006, p. 148). Similarly, corporate governance theory is drawn from various inputs, including the maturing of the corporate model, legal developments, property rights, and economic and political theory (New Zealand Institute of Directors, 2012, p.13). In many respects, agency theory is the antithesis of kaupapa Māori theory. Public sector reforms were predicated on agency theory, which assumes the 'self- interested actor rationally 
maximizing their own personal economic gain' (Donaldson \& Davis, 1991, p. 51). Cribb (2006) notes that Sundaramurthy and Lewis (2003) characterises agency theory as 'control', whilst Schick (1996) highlights that 'taking accountability seriously is a genuine triumph of New Zealand public management' (p.87). New Zealand has robust mechanisms in place to enforce accountability (Held, 2006, p. 216).

The extent to which Māori voices are genuinely heard in governance constructs is limited, as representation is often perceived as a token gesture. Angst is expressed among some Māori, and many Pākehā too, regarding the agency theoretical notions of control, hierarchy, and accountability, yet despite this concern, areas of Māori economic development and tribal affairs have been shown to be stronger for it, as evident in the size of the Māori economy, which has been estimated at $\$ 50 \mathrm{~b}$, with 30 perent held by Māori collectives, including post settlement governance entities, Māori land trusts, and Māori incorporations (Chapman \& Tripp, 2017, p.3).

The alternative to thinking about how Māori voices might be more influential in governance settings is to consider the relationship between stewardship theory and kaupapa Māori theory. There are more similarities between stewardship theory and kaupapa Māori theory than there are differences. Stewardship theory assumes organisational role holders are conceived as being motivated by a need to achieve, to gain intrinsic satisfaction through successfully performing inherently challenging work, to exercise responsibility and authority, and thereby to gain recognition from peers and bosses. Thus, there are non-financial motivators (Donaldson \& Davis, 1991, p. 51). Stewardship theory stresses collaboration, collective orientations, tapping into individuals' aspirations and motivations, and the importance of service (Cribb, 2006, p. 150). Māori principles such as kotahitanga (unity), kaitiakitanga (guardianship), and whanaungatanga (family) align closely with stewardship philosophies.

Alongside stewardship and agency theory, kaupapa Māori theory introduces Māori frameworks of values and principles as central tenets for re-shaping governance theory and practice. The application of good governance principles including responsibility, accountability, fairness, transparency, and impartiality alongside an equally substantive set of kaupapa Māori values would provide a good platform to start (New Zealand 
Institute of Directors, 2012, p. 8). The 2005 Hui Taumata made a strong call for developing effective leadership and governance throughout Māoridom and attempted to develop a model that incorporated tikanga Māori into leadership and governance training. A comparative exercise to marry a Māori leadership model, or pūmanawa model, based on Māori leaders' skills and talents, with the GLOBE Project (House, Hanges, Javidan, Dorfman, \& Gupta, 2004) was an attempt to suggest the potential contribution Māori leadership thinking can make to international leadership theory (Mead et al., 2005). The Hui Taumata (2005) paper identified two drivers concerning Māori in the public sector:

- the flattening of management structures in the 1980s and 1990s, resulting in a more technically task-oriented public service

- under-representation of Māori in public sector head offices.

The issue of biculturalism in the New Zealand public sector addressed by Mason Durie (1993) and Kim Workman (1995) resulted in proposals to the government, in consultation with Māori, to develop a comprehensive policy and strategy for biculturalism in the public sector. Workman included proposals to hold chief executives accountable for developing organisations that are responsive to Māori; ensure responsiveness strategies to Māori address the core business of government organisations; identify the government agency or agencies responsible for providing leadership in the development of responsiveness and monitoring the performance of chief executives; develop a comprehensive Māori workforce development strategy; acknowledge the development rights of indigenous people; and develop the expertise of public service staff in understanding Māori policy issues and analysis and recognising the unique characteristics of Māori policy. Workman developed He Anga Tikanga-a-Rua (a bicultural framework) as a model for agencies to evaluate their progress to becoming bicultural. Despite reservations, Workman found renewed interest in the development of biculturalism based upon the experience of the previous 10 years in developing government organisations that were more responsive to Māori (p. 4).

The context of kāwanatanga provides a space for advancing biculturalism in the public sector by linking traditional Māori concepts, such as mana, as an alternate view to the well-trodden but unproductive deficit pathway based on ethnic-based statistical 
measures, to develop bicultural goals and strategies. Māori scholars such as Royal (2006) have addressed the traditional concept of mana, expressing that mana lies at the heart of Māori, indeed human, health and wellbeing (p. 8). As opposed to using statistical measures of the Māori community - such as the need to address significant disparities in health, education underachievement, imprisonment rates, and so forth - or cultural outcomes - such as the need to develop models for identity and cohesion, both within the Māori community and between the Māori community and the New Zealand community as a whole - Royal argues the greatest challenge facing Māori development concerns the restoration and fostering the experience of mana. Royal identifies that, as Māori, one is not able to speak about one's own mana; rather, it is more appropriate that Māori have other people speak on their behalf when it concerns talking about their achievements, attributes, and qualities, thereby enhancing their mana. Royal (2006) also suggests New Zealand equally needs to accept its share of responsibility for its poor record in addressing disparities in Māori health, education, and so on (p. 9). Other Māori scholars, such as Harmsworth and Awatere (2013), have made the connections between indigenous Māori knowledge and Western science and environmental ecosystems relevant in government agency contexts, and Harris et al., (2016) have examined Māori values in the workplace/investing in diversity giving credence to adopting Māori concepts and methodologies within kāwanatanga - as a leadership practice.

\section{Māori Leader Models}

The literature provides excellent biographical accounts of Māori leaders' achievements, exploits, and legacies. Titles such as A Fire in your Belly: Māori Leaders Speak (Diamond, 2003) and The Spirit of Māori Leadership (Katene, 2013) provide clues to the intangibility, emotion, and expression that sits within Māori leadership. Tribal and Māori academic leaders characterise the modern Māori leader profile as being wise because of their long lived and learned experience in both the Māori world and the Pākehā world. Within the field of public administration, the Māori leader model is based on the experiences, knowledge, and skills of public servant Māori leaders spanning time between the nineteenth-century Māori leader Wi Maihi Te Rangikaheke, who wrote critical manuscripts and educated Governor Grey in te reo and tikanga Māori, and modern Māori leaders such as Parekura Horomia, Hekia Parata, and Shane Jones, who each made the transition from senior Māori public servant to Māori politician (Katene, 2013). 
Stories of Māori leaders in the public sector also take the form of legacies, major policies, events, and remembrance contributions. Tu Tangata (stance of the people) was an approach fashioned and implemented by charismatic Māori leader Kara Puketapu that provided a model that would re-shape the Department of Māori Affairs in the 1980s. This model emphasised the need for the Māori communities, rather than the Department itself, to lead, supported by a 'kōkiri' administration that would better co-ordinate resources and harness effort with the Department. Tu Tangata gained impetus and resonance among Māori communities. 'Fronting up' was the phrase it used, imploring Māori public servants to do just that and meet face to face with Māori communities (Puketapu, 1982). Tu Tangata was a model of Māori leadership practice for the time, and its implementation would have necessitated strong Māori leadership. Individual Māori leaders such as Kara Puketapu would have to withstand and persevere with the discrimination and oppression Māori working in the public sector would face during those times.

The relationship between Māori leaders and leadership practices is evident in several flagship policy programmes. The classic example is the landmark report Puao-te-Ata-tu (1988), the report of the ministerial advisory committee on a Māori perspective for the Department of Social Welfare. It was led by John Rangihau, and focused attention on government's responsiveness to Māori. The report highlighted legal, institutional, and cultural perspectives, grounded in the lived realities of Māori in communities throughout Aotearoa New Zealand. For Ranginui Walker (1996), Puao-te-Ata-tu was exceptional because it was truly a policy for the people. It was ground-breaking in that time because the voices of Māori people were heard. Puao-te-Ata-tu excited Māoridom, but asked the question, where is it now? Puao-te-Ata-tu had the potential to enable resistance strategies within kāwanatanga; however, the Department of Social Welfare saw it as a threat to the Pākehā position and an imposition on the bureaucratic system (O'Regan \& Mahuika, 1993). The leadership legacy of Puao-te-Ata-tu is continuity of remembrance in Māori communities, as it captured the hopes and aspirations of the time for Māori children and their whānau. It created a vision and a pathway, and represented Māori voices within the bureaucracy. 
Another important contribution to Māori public leadership is the book by Gardiner (2014), Kia Ora, Chief!, - a biography of Parekura Horomia, the well-loved Māori leader, senior Māori bureaucrat turned politician from Tologa Bay. The story of Parekura Horomia is a modern example of Māori leadership practice. His career as a public servant is remembered for the influence he had on encouraging a better response to Māori from government agencies; establishing Māori perspectives units; and expanding roles for Māori within the wider bureaucracy, followed by increasing governance positions (Gardiner, 2014, p. 105). Gardiner also points out that Parekura's leadership style did not fit readily into the major conventional models of leadership (ie, authoritarian, paternalistic, democratic, transactional, transformational, or inspirational). Rather, elements of each of these styles can be attributed to Parekura. Parekura's life revolved around traditional Māori concepts. This is not uncommon; however, Parekura was unique in his public service role, as he had a deep understanding of the concepts, and an ingrained level of experience and practice to give effect to them. Gardiner says the difference in this leadership model is 'Parekura invested his own mana and prestige into the process' (p. 421).

In many ways, this group of Māori leaders, including John Rangihau, Kara Puketapu, and Parekura Horomia, among others, has provided the beacons for Māori leadership practice in public administration. Māori leader role models make the phenomenon of Māori leadership in the public sector real. Māori leadership does exist. However, in this thesis I want to inquire into the sustainability of the individual Māori leader model in a modern public-sector environment. Times are not like they used to be. The study examines to what extent that pattern is shifting from the individual 'heroic-charismatic' (traditional cultural-political) model towards the emergence of a L-A-P model that suggests strategic, collective, and relational elements are prioritised over individual characteristics and traits (Raelin, 2011).

\section{Central Agency Responses}

The statistical profile shows there is a lack of Māori representation in senior levels of public administration in New Zealand. The New Zealand public sector employed around 353,500 people (known as public servants) as at 30 June 2016: about 14.4 percent of the country's total workforce. The state sector employed around 300,000 people, and local 
government had around 53,500 employees. Over the period 2011-2016, the publicsector workforce grew by 4.2 percent, compared to private sector growth of 14.1 percent. Māori representation (16.1 percent) in the public service workforce continued at high levels compared to Māori representation in the overall New Zealand labour force (12.7 percent). However, Māori, Pacific, and Asian ethnicities are still under-represented in the top three tiers of public service management. European staff are over-represented as managers and policy analysts. Māori and Pacific staff are well represented as inspectors and regulatory officers, and as social, health, and education workers, but less so in other professions. Māori, Pacific, and Asian public servants are over-represented in occupation groups that are lower paid (State Services Commission [SSC], 2016a). This will take time and deliberate effort to increase, as non-European ethnicities are also under-represented at lower levels of management.

Government responses to Māori leadership in the public sector have consisted of sporadic attempts to understand the issues but little in the way of consistent or systemwide implementation of effort. In consultation with Māori public servants, the State Services Commission issued (in 2004) the draft Leadership Capability Profile. The responses from central government agencies signaled two aims issues: to increase Māori representation in the public sector (SSC, 2006a) and to build capability to address issues for Māori (Office of the Auditor General, 2004). The SSC (2005b) EEO [equal employment opportunity] Policy to 2010 also had an emphasis on achievement for Māori, with specific objectives to establish a 'critical mass' in each department in order to build public service managerial, policy, and service delivery capability. This policy identified three main drivers for EEO for Māori in the public service: the Treaty of Waitangi, social justice, and good business practice. It also recognised:

1. the status of Māori as tangata whenua under the Treaty of Waitangi

2. the increasing importance of Treaty considerations

3. the need for the public service to enhance its internal capability to develop effective policies and service delivery mechanisms for Māori.

From a positive viewpoint, this represented gains, including the positioning of 'diversity' and 'equal opportunities - with a special focus on Māori' as something recognised as important by Māori. Central agency reports such as those mentioned above addressed 
the issues of understanding the Treaty of Waitangi; developing, building, and maintaining effective relationships with Māori; working to improve responsiveness to Māori; interacting appropriately with Māori; and enabling people from diverse backgrounds to work together to effectively reinforce culturally sensitive behaviour and foster a culturally safe working environment (Office of the Auditor General, 2004).

In recent years the focus of the SSC has been on leadership development. The SSC's (2014) Getting to Great report provided findings from performance improvement reviews of government agencies. The report suggests that agencies struggle with defining purpose and with creating a galvanising collective ambition that reflects the value the agency creates for New Zealanders. The report found that most senior teams are good at responding to short-term priorities or crisis situations. Their collective leadership styles more often focus on managing issues and incidents rather than on building great institutions. Some spend more time on operational matters than on strategic discourse, and whilst they might talk long-term strategy and stewardship, they behave reactively in practice (p. 11). The report provides an excellent account of leadership from respected public-sector leaders who have already achieved distinctive, lasting, and substantial improvement in the people space (p.9). The key theme to emerge, which I found resonates with Māori leaderhip, is the notion that those who value authentic leadership are those who are confident to show their 'whole self' at work, including admitting mistakes and leading with head and heart (p. 8).

The SSC produced Leadership Insight in 2016, which allows the SSC to identify priority areas for development, investment, and planning; provides the most comprehensive picture of senior leaders; and signals that lifting system performance requires a culture shift (p. 3). Leadership Insights gives the most comprehensive picture of senior leaders the SSC has ever had. Initially 480 people had been invited to participate in Leadership Insights. The results from this report include assessments of 243 leaders (51 percent of senior leaders) who had been assessed as at 16 March 2016. This sample size is large enough to draw meaningful conclusions about New Zealand public sector leadership in general. However, as at 16 March 2016 the sample size was too small to provide a meaningful view of ethnicity. Leadership Insights was silent in relation to the contribution of senior Māori leaders. This is problematic because it can be assumed by Māori therefore 
that the common leadership philosophy is one size for all public-sector leaders. Henceforth the relevance of this thesis becomes clearer which is to consider an alternate view, a Māori view, of public sector leadership practice within the broader context.

While I was reviewing government responses, I wondered why the issue of Māori representation and capability was so pronounced. Why is there only one Māori public sector chief executive (at Te Puni Kōkiri)? Why do the efforts from central agencies appear to start and stop? Why are Māori mostly invisible in the top tiers of government? The issues appear to go deeper than what is seen on the surface and reach into issues of authorisation and power, understanding and valuing Māori diversity, and addressing equity. Social, economic, and demographic indicators show Māori populations are in greatest need of public services, yet the positioning of Māori leadership inside the public service, as part of the solution, is not visible as a system-level priority. There is no systematic approach; nor is there a recognised Māori approach to developing Māori leadership and career pathways for Māori public servants. The paucity of public sector literature in this specific field means the critical Māori elements appear not to be well understood by the majority population, with no clear descriptions and practice guidelines. Moreover, an ambivalent attitude to kaupapa Māori perspectives of leadership and how those perspectives differ from equally contested conceptions of Western leadership reinforces an awkward lack of substantive engagement by the public sector in this area.

This thesis argues that research into lived experience is obligatory to establish the Māori narrative and develop appropriate levels of support for agency chief executives to adapt their perspectives and attitudes towards Crown-Māori engagement, Māori leadership, and relationships. Richer and deeper insights into the Māori perspective may enlighten government agencies about the value of Māori ways of knowing and doing, so that they can recognise difference and develop ways to address senior Māori leadership representation and development in the public service.

\section{Māori Public Servants}

Perception of Māori public servants is a major concern. Cribb's (2006) research found that public servants could be, or at least could be perceived to be, operating as principals 
with a monitoring focus, and organisations perceive that they are being treated as agents. This was Aroha Mead's (1994) concern: that Māori public servants position themselves as experts and superior agents. Māori (organisations) are cast as inferior, and public servants work to maintain the power imbalance (Cribb, 2006, p. 137).

Historically the political discourse has resulted in confusion amongst Māori and government agencies, inferring that policy-making, for and on behalf of Māori, is assumed by the Crown. This issue was highlighted by Mead (1994), who considered that Māori senior public servants are working within the Crown philosophy that is content to develop policies about Māori without involving Māori (p. 8). A common indigenous experience has seen public agencies assume positions of leadership on behalf of indigenous peoples. However, not only does that approach foster both dependency and assimilation, but it also undermines indigenous leadership (Durie, 2004c, p. 14).

Whilst agency theory provided the underpinnings for contracting services to Māori, public servants could also be, or least be perceived to be, operating as stewards focusing on long-term relationships, with shared goals, operating with more discretion, and motivated because of the kaupapa (purpose) (Cribb, 2006, p. 150). The critical observation is that Māori public servants attend to both roles, as principals and stewards, and tried to do the best they could. Some found themselves walking in two worlds, negotiating governance arrangements that included both 'hard' factors, such as structure, rules, processes, and mandate, and 'soft' factors, such as people and relationships (Boston \& Gill, 2011, p. 237).

There is a positive perception that some Māori public servants are very skilled, savvy with politicians (some even becoming politicians), and very accustomed to the machinery of government and its nuances. The downside is that Māori public servants are to manage dual expectations of Māori and the public sector. In many cases Māori public servants, although they are not responsible, nor have the power, are the ones who 'front up', and they would feel the brunt of Māori dissatisfaction with government. Perhaps this is a legacy from the previous Māori affairs regimes of Tu Tangata and the kōkiri process, whereby 'fronting up' to the Māori community is an embedded approach (Burns, 1982). 


\section{The Crown-Māori Interface}

Fundamentally, there is a need for a mindset shift away from the pervasive assumption that the Crown is Pākehā, English-speaking, and distinct from Māori rather than representative of them. Increasingly, in the twenty-first century, the Crown is also Màori.

(Waitangi Tribunal, 2011, p. 451).

The Waitangi Tribunal (2011) statement quoted above signals that the twenty-first century post-Treaty settlement period is a new time and space whereby iwi who experienced the pain and anguish of loss of land and taonga no longer must contend with the anxiety of insecurity. The world has changed for Māori tribes that have settled Treaty claims with the Crown, and they now display growing confidence in building Mãori social, cultural, and economic futures. The rise in confidence, assets, and capability means that both Māori and government agencies are compelled to think differently about how to lead and manage at the Crown-Māori interface. This has created a space where working together, in the spirit of partnership, enables questions to be asked such as 'what constitutes valued outcomes; why it matters and trust (between Māori, citizens and government) can now be openly deliberated on' (Williams \& Shearer, 2011, p. 6).

The changing nature of the Crown-Māori interface has been recognised by the SSC, which has taken steps to shift leadership thinking towards highly collaborative and joined-up approaches and systems-level thinking. The SSC has identified four key priorities; first is the connection between developing public sector leaders and improving the lives of citizens and delivering better public services; secondly, a change in approach to developing leaders is necessary; thirdly, we need to acknowledge that the Māori world and relationships with the Crown are changing; and fourthly, the Crown-Māori space is 'dynamic and evolving, requiring new and different ways to deliver government services' (SSC, 2014).

Government agencies such as Te Puni Kōkiri provide a host of publications and tool-kits; for example, Building Relationships for Effective Engagement with Māori (Te Puni Kōkiri, 2006b) and Crown-Māori Instruments: Guidelines and Advice for Government and State Sector Agencies (Te Puni Kōkiri, 2006c). These are helpful for public servants who are 
involved at the interface. Durie (2003) stated that at the interface between the Crown and Māori are two broad themes; the first is the role of the state in either facilitating or blocking Māori development. The second is the capacity of Māori to take advantage of windows of opportunity in a situation of change to realise aspirations for cultural, social, and economic advancement. Durie identified the interaction between Māori and their rights to self-determination and the 'growing power of the state' in the following areas:

- participation in environmental protection and management

- cultural identity and heritage

- social policy

- land issues

- fisheries

- Te Tiriti o Waitangi.

In a modern post-Treaty settlement context, these matters, as well as globalisation, digital technologies, and communications, continue to be relevant. Katene (2013) makes the connection between political influence, economic power, broader socio-economic development of Māori, and Māori taking an active role in the design and implementation of Māori policy and strategies - which he states as a function of Māori leadership. Māori leaders of the future will need to confront: the 'Crown's relationship with Māori, relationships between Māori; and a shift from a commodity-based economy to a knowledge economy' (Katene, 2013, p. 202)

\section{A Crown Engagement Problem}

The Honourable Dr Pita Sharples framed the Crown-Māori interface as an engagement problem: 'the Crown's long history of not allowing Māori to speak through their own voice'. He states that in a post-settlement environment, we 'need mechanisms that will enable Māori to do so [speak through their own voice] in their engagement with the Crown' (Chen, 2012, p. 516). When barriers for Māori voices to be heard are so entrenched in the democratic and administrative process, the concept of engaging with Māori is a welcome opportunity for Māori. What is important is to establish is a legitimate process whereby the practice of engaging with Māori is deliberative and substantive. As Manin is quoted as saying, 'the source of legitimacy is not the pre-determined will of 
individuals, but rather the process of its formation, that is, deliberation itself' (Held, 2006, p. 233).

The practice of public sector agencies engaging with Māori is a learning process for all parties (Gregory, personal communication, 2013). Engaging with Māori is a principlesbased approach. Held (2006) focuses on principles of reciprocity, negotiated order, and legitimate governance (p. 244). From start to finish, careful consideration must be given throughout every step of the journey. Key decisions are made about membership, representation, type and level of engagement, frequency of meetings, agenda setting, location, and the costs of participation. Kaupapa Māori theory, which underpins the practice of engaging with Māori, would prioritise the principle of 'kanohi ki te kanohi' (literally, face to face). It is through this practice and process of kanohi ki te kanohi one finds many underlying facets of relationship-building, such as concepts of tika (honesty), pono (truthfulness), mana (respect), manaakitanga (hospitality and care), and utu (reciprocity). Cram and Pipi (2000, p. 14) wrote:

Kanohi ki te kanohi is regarded within Māori communities as critical when one has an important 'take' or purpose. This form of consultation allows the people in the community to use all their senses as complementary sources of information for assessing and evaluating the advantages and disadvantages of becoming involved.

The concepts of 'kanohi ki te kanohi' and maintaining relationships is important for Māori public servants. It is a reference to whakapapa and the connections of the 'seen face' and his or her ancestors to a particular place. During formal speeches, whether at board meetings, stakeholder hui, or tangihanga (funerals), orators will connect members and guests to their iwi, hapū, or whānau and recall stories of the deeds of ancestors. Opportunities to learn, listen, and share in this process of engagement are important for public servants. It is important to consider tikanga Māori as a necessary pre-condition for engagement and transformation and to then be able to explain why it is important from a kaupapa Māori perspective. This explanatory work cannot be done by consultation. There needs to be a process of meaningful and respectful dialogue. 
Moreover, there are traps that are easy to fall into as public servants. Metge and Kinloch (1978) highlight that the trap is to 'talk past each other', and problems occur with crosscultural communciation. My experience confirms that as a Māori person who is familiar with Māori language and culture, and familiar with public sector language, terms, acronyms, policies, and rules, it is very easy to sound like a 'bureaucrat'. The words may come out right, but they are heard differently. They are heard with Māori ears and from a specific Māori perspective. The second important trap to be aware of is the 'power trap'. As a public servant, the pendulum is swung in your favour, as you have the power of the Crown, the status of the position, the salary, the paid travel, the education, and the access to expertise. What do Māori have? Māori are fortunate if they have their language, their tikanga, and their mana. Peter Hughes acknowledges this point. He says, 'the first thing I do is address the power imbalance. I give them as much control as I can. Then I have an open and honest discussion with them. We address their questions. If I don't know the answer I say so. I am upfront and open' (SSC, 2014, p. 44).

Restoring a level playing field for power can be made possible through creating a shared space that is underpinned by shared principles and supported by good leadership practice. This is a form of leadership practice that is focused on the process of engaging with Māori whereby the most critical negotiating points concern values of openness and honesty to create a platform for ongoing relationships. A solid platform requires leadership that demonstrates humility, respect, a willingness to listen, and reciprocity.

\section{Deficit Mindsets}

As the key Māori policy ministry, Te Puni Kōkiri (2006a.) introduced the Māori Potential Framework to better position Māori to build and leverage off their collective resources, knowledge, skills, and leadership capability to improve their overall life quality (p. 12). The Māori Potential Framework resonated across the public sector, as it shifted the lens towards what is possible and potential, and away from 'deficit thinking' and casting Māori as the problem. As an example, Bishop and Glynn (2003), working with the Ministry of Education and other education researchers and teachers, developed the Te Kotahitanga programme to improve Māori student achievement. Underpinned by focusing on strengths, opportunities, and potential, it shifted the focus from addressing problems and disparities to expanding on success. The Māori Potential approach supported a pedagogy 
of cultural responsivesness and relations that emphasised the inherent cultural capability and advantage of Māori language, culture, and identity.

The study 'What Works with Māori', conducted by the Families Commission, identified that the public sector urgently needs to research what is working for Māori and what public policy is getting right, and to share the stories and lessons from this research (Irwin, K, etal, 2013). According to the study, research in the Māori public policy arena has focused on disparities, providing statistics and telling stories of what is not working. This paradigm may have dominated the policy agenda, producing the evidence of the need for change, for decades. What is needed now is an equally focused research programme on what is working, so that solutions are sought with as much vigour and resource (Irwin, Hetet, Maclean, 2013, p.131).

The vacuum in understanding and interpretation of Māori leadership concepts and their application and relevance in public administration persists. Despite an ongoing dialogue and debate about Crown-Māori relationships and the place of Māori culture and language in society, there are gaps in knowledge about what Māori success and Māori potential looks like, what public value is created, and how value is authorised and produced (Moore, 1995).

\section{Perspectives of Rangatiratanga}

According to Hirini Moko-Mead, 'rangatiratanga' in Te Rangikaheke's terms was about mana and the mandate of a leader (Katene, 2013, p. 15). The distinction is made between traditional rangatira leadership and Māori representative or appointed leadership. Bishop (2003) cites comments from Professor Whatarangi Winiata, who considers the term 'leadership' to be too narrow and prefers the use of the term rangatiratanga, quoting Manuhuia Bennett's whakataukī:

Ko te kai a te rangatira he kōrero

Ko te tohu o te rangatira he manaaki

Ko te mahi a te rangatira he whakatira i te iwi
The food of chief is communcation

The sign of the chief is looking after the people

The job of the chief is to unite the tribe 
The concept of rangatiratanga is strongly linked to the concept of whakapapa. As Mead states, through whakapapa identity one is connecting to the tribal base or home, for it is at home that the rangatiratanga is (H. Mead, personal communication, 1 July, 2014).

Te Whata and Kawharu (2012) suggest there is no definitive answer on Māori rangatira leadership, but instead a range of possibilities and probable features. Their overview of literature highlights key sources and statements made by Māori leaders held in high regard, of standing, having mana. For example, at the Māori leadership hui held in Tūrangi in 1989, Reverend Bishop Takuira Mariu made the statement:

Unity of mind, of heart and of action ... for the spiritual and physical wellbeing of our people and our nation ... he goes on unity ... does not mean sameness, but rather the ability to come together on issues and ... form a mutual understanding.

Whilst both Winiata (1967) and Walker (1993) discussed traditional Māori leadership, it was only really Walker who engaged with the impact of Western colonisation and structures. Katene (2013) described Sir Peter Buck, Sir Apirana Ngata, and Maui Pomare as intellectual organic leaders who epitomised a shift in the focus of Māori leadership, from a point of tradition to a point where leadership roles were determined from above by a culture of domination. Whilst supported by their own iwi, hapū, and whānau, these leaders were ultimately subjected to measurements of leadership held within the structures, politics, and culture of dominant Pākehā culture (Walker, 1993).

Walker's (1993) paper 'Tradition and Change in Māori Leadership' canvassed the complexity of issues related to leadership and decision-making, and stated:

western colonial establishments such as western governance structures, pre-empted the emergence of new forms and models of Māori leadership. These forms and models included 'intellectual organic leaders' and 'new institutional mandates'.

Walker argued:

traditional Māori values, processes and practices associated with Māori leadership and decision-making is often contradictory and incompatible with the modern demands of the contemporary social political and economic circumstances of Māoridom. 
(Walker, 1993, p. 23)

The purpose of rangatiratanga is to weave the group into one - to provide a sense of unity (Katene, 2013, p. 13). Jackson (2013) concludes there are multiple understandings of the discourses of rangatiratanga that allow for certain meanings and not others. A discursive analysis of rangatiratanga in a Māori fisheries context identified multiple interconnections within and between each of the emergent discourses of rangatiratanga. The discourses that emerged included:

- rangatiratanga as possession

- rangatiratanga as chieftainship

- rangatiratanga as trusteeship

- rangatiratanga as authority

- ranagtiratanga as mana, including mana whenua and mana moana

- rangatiratanga and sovereignty

- rangatiratanga as self-management/tribal sovereignty

- rangatiratanga and governance (Jackson, 2013, pp. 3-17).

Whilst there is extensive literature on leadership, the modern literature on Māori leadership is still growing. Katene's (2010) article on modeling Māori leadership concerned itself with various leadership theories that help explain what makes for good leadership from a Māori perspective. Katene has since produced the book titled The Spirit of Māori Leadership (2013), which provides a comprehensive account of traditional and historical perspectives of Māori leadership alongside parallel Western theories of leadership, such as transformational, charismatic, distributive, and organic forms of leadership. Katene (2013) identified that Māori public servant leaders in the modern era have a common aim: the realisation of collective Māori aspirations. They work within the state apparatus as reformists, and this is consistent with transformational leadership (p. 145). Katene's (2001) research, undertaken with 30 Māori leaders from seven different public service organisations, asked the question 'What makes a good leader?' Four categories were identified: confidence in one's own abilities, shared vision and common values, self-motivation, and being people-centred. Katene concluded the research found Māori public servant leaders grappling with their 'dual accountability' roles and reinforced the relevance of the servant style of leadership (p. 178). 
Māori scholars have explored various aspects of Māori leadership. Pihama and Gardiner (2005) found the topic of Māori leadership is clearly complex but provided a fascinating insight into the way Māori think and how to consider the qualities of a Māori leader. They developed baseline data on enhancing whānau wellbeing, whānau leadership, and engagement, and on innovation and enterprise that facilitate whānau development and the realisation of Māori potential, both to inform policy advice and to contribute to the outcome of Māori succeeding as Māori (p.4). Māori scholars have also helped considerably to think about how Māori leadership practice is further differentiated from other concepts of leadership, as it is underpinned by Māori epistemological foundations (mātauranga Māori), expressed through kaupapa Māori (Smith, 1997), tikanga Māori (Mead, 2003), mātauranga-a-iwi (Doherty, 2012), and the centrality of whakapapa (Edwards, 2012).

With respect to public sector literature on Māori leadership, Ngā Toka Tū Moana (literally, rocks standing in the ocean), prepared by Ngā Tuara (1992), is a foundation document that helped to build an understanding of the changes to the traditional model of Māori leadership (rangatiratanga) and decision-making, including the evolution of Māori organisations and initiatives from that period. The report confirmed that:

1. there was a well-established leadership and decision-making system in traditional Māori society

2. the social groups of waka, iwi, hapū, and whānau provided the traditional Māori with an established social and political structure within which various levels of leaders worked and decisions were made (Ngā Tuara, 1992, p. 6).

In Ngā Toka Tū Moana, the term leader was taken to mean:

a person who takes a prominent role in persuading the people to make decisions which affect their well-being and future. It is a general term for the dedicated people, men and women, who have a vision for their people and who strive to work towards that dream. It includes both traditional and non-traditional leaders.

(Ngā Tuara, 1992, p. 6). 
The use of Māori proverbs to reinforce key points is a key feature of $\mathrm{Ng} \bar{a}$ Toka Tū Moana, as the proverbs remind us that basic truths are as relevant today as they were generations ago. Examples include 'Ehara taku toa i te toa takitahi, engari he toa takatini' (The strength of the leader is the strength of the group) and 'a leader is a "kanohi kitea", that is, the leader's face is often seen among the people served' (Ngā Tuara, 1992, p. 50).

\section{What is Māori Leadership?}

According to Te Rangikaheke, traditional rangatira leadership talents were inherited and came from 'te kōpū o tōna whaea' (the mother's womb). According to Tikitu, Te Rangikaheke said of such talents, Nā te moenga rangatira ēna mea': 'Those things come out of the chiefly marriage bed' (Best, 1898).

Himiona Tikitu of Ngāti Awa identified having expert knowledge, skills, and personal qualities, not just lineage, as needed to govern people and manage tribal affairs. Raymond Firth described these extra talents as 'executive capacity' (Katene, 2013, p. 19).

Both Wi Maihi Te Rangikaheke and Himiona Tikitu provided specific lists of qualities and talents of Māori leadership. Talents revolved around the command of knowledge, strategies of warfare, welcoming and hosting visitors, conducting meetings, mediating disputes, cultivating food, knowledge of arts, carving, and tribal boundaries. The worth of a leader was having relevant knowledge and expertise, not just lineage; what Raymond Firth describes as an 'executive capacity' (Katene, 2013, p.19). Hirini Mead et al. (2005) developed this list further with a new pūmanawa (talent) model to apply in a contemporary setting, in which leadership attributes included leading a community forward, successfully completing big projects, and upholding rights of hapū and iwi in other contexts, such as the Māori Land Court and Waitangi Tribunal. It was recognised by Mead et al. that leaders need to have a wider vision and a more general education than is required for everyday matters. It is noted by Katene (2013) that being able to give effect to pūmanawa is predicated upon a leader having a mandate to lead the people and being accountable to the mandating body for his/her performance (p. 182). The thrust of such lists and descriptions is the focus on talents, skills, traits, and characteristics. There is no distinction, from the traditional perspective, between the qualities of a leader and qualities of leadership. 
Māori scholars have asserted the importance of various cultural concepts in informing their leadership practice. Henare (2010) and Williams (2010) argue cultural concepts differentiate Māori leadership from other conceptions of leadership. Traditional Māori concepts such as mana (prestige, authority, control, power, influence, status), tapu, (sacred, restricted), manaakitanga (hospitality, generosity, care), tikanga (customary practices and correct procedures), and aroha (love, compassion, empathy) are the foundation for Māori leadership.

The concept of whakapapa is derived from Māori epistemology. Te Puea Herangi stated the fundamental principle of leading is whakapapa. The true meaning of whakapapa is 'that which binds us to the wairua of our ancestors and the Gods'. Leadership, then, is 'the ability to act and think in accordance with the guidance that whakapapa shares with us' (Billing, 2004, p. 29).

Two modern prominent leaders, Sir Hepi Te Heu Heu, ariki and paramount chief of Tuwharetoa, and Te Arikinui Dame Te Ātairangikaahu of Te Kīngitanga, epitomised the whakapapa principle of leading. Katene (2013) described Te Heu Heu, stating 'his quiet and unassuming effectiveness epitomised his mana and style of leadership' (p. 24). Katene refers to Te Arikinui Dame Te Ātairangikaahu as having a 'caring and benevolent nature, moving easily among people at all levels. Her wisdom, astute thinking and clear vision established her as an unparalleled unifying force for Māori' (p. 25).

Smith (2015) has stated that Māori leadership must enable the social, cultural, economic, and political wellbeing of Māori. Smith makes three pertinent points about Māori to take into consideration within this thesis. First, he acknowledges Monte Ohia's statement in his $\mathrm{PhD}$ thesis that the fundamental premise of good leadership is the necessity of moral and ethical leadership practice, balancing knowing when to invest in your own expertise and when to take advice from others and move with the group. The second point, which is Graham Smith's own idea, is to move away from the use of the word 'transformational' and emphasise the word 'transforming' to capture the notion of continuity of changes and, therefore, continuous improvement. The third point Smith emphasises is based on his experiences and observations working with Sir Hirini Mead. He refers to Sir Hirini Mead as a person who has done it all. He is a model of Māori leadership. He has proven 
excellence in the Māori knowledge domain academically and as a cultural practitioner. He works in iwi and Māori community contexts and is acknowledged in both Māori and Pākehā worlds. Smith's view is that Mead has enacted his transforming work within practical projects and brings his theorising together with practical outcomes (Smith, 2015, p. 114). The thinking of Māori academics forms a perspective of Māori leadership practice that incorporates the transforming, continuity, collective, and action-oriented elements. There is a clear perspective, too, that recognises the context that Māori leadership practice in public administration must engage with and is concerned with social justice and equity outcomes, given the unequal power relations between the dominant kāwanatanga system and subordinate Māori interests (p. 113).

\section{Rangatiratanga and Leadership}

Building on the traditional theme of rangatiratanga and leadership, Tipene O'Regan provides a view on the difference between Māori and Pākehā views of leadership. One of the first differences he mentions is having a clear group of people to lead. In a Māori context, this might refer to a whānau, hapū, or iwi, or Māori organisation: to represent their views or represent a position on their behalf, one must have a clear mandate. Moreover, one has to develop a view of the horizon and what might be possible, then to be able to articulate it in a way that people can engage in it. To do that, you have to have some measure of belief that you have the capacity to get to a particular horizon (Fogarty, 2006, p.7). O'Regan's statements in 2008 are consistent with the statements Te Rangikaheke was making in Governor Grey's times. Modern-day descriptions of 'rangatiratanga as leadership' revolve around notions of bringing people together, creating a vision, and communicating clearly. The element of inner belief is not fully explained in O'Regan's statements, but is closely aligned to the concept of mana.

Snedden (2005) offered pertinent perspectives in his article titled 'Rangatiratanga and Leadership'. Pat Snedden worked for a quarter of a century as a close ally to Ngāti Whātua throughout the Bastion Point land claims and settlement process. The article title simply sums up the notion that rangatiratanga is leadership and leadership is rangatiratanga. What intrigued Snedden was that, when the outcome of the Wai 9 Bastion Point case was in favour of Ngāti Whātua and the land transferred back to the iwi as an act of Parliament, the first thing Ngāti Whātua did was to gift the land back to Aucklanders for unimpeded 
use. Snedden asked what it was that enabled an iwi who for 150 years sought justice that recognised their cultural destitution to react in their moment of truth with such generosity to those who had dispossessed them. He said, 'To put it simply, their rangatiratanga, their mana'. Snedden advocated rangatiratanga as the value of working beyond your self-interest; in Māori terms, the leadership of collectives (iwi/hapū) demands the exercise of both rights and obligations. He stated, 'there is no mana without manaakitanga, there is no rangatiratanga without utu' (p.21).

Harvey's (2007) description of Sir Pita Sharples provides another example of the connection between the concept of rangatiratanga as leadership and mana. He writes of Pita Sharples, 'Leadership sets you free, it gives you a sense of doing something that matters'. Harvey provides an indication that Māori leaders have a different view than Pākehā; they are selected and are given a role they can never step back from. With reference to Pita Sharples, he writes, 'Pita exudes mana, he is always immersed in tikanga Māori and is always prepared to find new ways to deliver it to the young. He has worn the cloak of leadership with humility and wisdom' (p. 19).

The general understanding of mana as a leadership concept is one that many New Zealanders are familiar with. The term is used in a range of settings, people understand that when a person has mana, they are a person of integrity, a person who is respected, and a person who has achieved many things by putting other people first, working with and for the people. In current times, the word mana is applied to non-Māori as well. People would say Richie McCaw has mana because of the way he became a great All Black and captained the All Blacks to back-to-back Rugby World Cup victories. In the Māori world, the use of the word mana is usually reserved for those who have, well, mana. They may or may not necessarily have formal authority or a position of power, such as an All Black captain or the chief executive of a government agency, but they have other important qualities, such as whakapapa, knowledge, and experience, and embrace Māori values in a way they are able to bring to bear and provide wisdom of thought and direction. This mana or 'power of Māori leadership' enables and mobilises people and resources towards doing what is right for the tribe and community. 
There are multiple perspectives of kāwanatanga and rangatiratanga, such is the dynamic, fluid, and, at times, tense nature of the relationship and history between Māori and the Crown. This dynamism highlights the complexities that surround operating at the interface, the importance of understanding the context, and how leadership practices that are relevant to the context emerge. We now move on to to exploring public-sector leadership literature to find potential connections and where gaps might exist.

\section{Public Sector Leadership}

Leadership is essentially a phenomenon of social interaction, social change and individual change - definitively philosophical yet practical because it is grounded in the experience and values of people engaged in the leadership phenomenon.

(Fairholm, 2004)

The review of literature identified that there is a lack of nuanced and empirically informed understanding of the daily enactment of Māori leadership in specific organisational settings. In a general sense, insufficient attention has been paid to the lived experiences of public service professionals (Thomas \& Davies, 2005, p. 1). According to Rhodes (2014), studies of administrative leadership are hard to find. A review of international public-sector leadership literature confirms how distant Māori leadership is from concepts of leadership within public administration. I find Māori leadership in public administration is clearly a specialised niche and yet to make an impact on publicsector leadership literature.

From a research perspective, there is much more to be learned and understood about the Māori experience of working inside kāwantanga and recognition of Māori leadership practices. There are some encouraging signs. In the field of Māori-medium educational leadership, the Education Council of New Zealand is pursuing a Māori leadership research agenda to develop a future vision of Māori leadership and leadership, in general, across the teaching profession. The Ministry of Education (2010) instigated Tū Rangatira as a leadership framework guided by four underlying principles:

- Māori potential

- cultural advantage 
- inherent capability

- mana motuhake

Tū Rangatira acknowledges that effective leadership practice requires that there are many participants, learners, whānau, iwi, educators, Māori communities, and government working together to maximise success for Māori (Ministry of Education, 2010, p. 7). The Education Council's Māori leadership strategy noted the disconnectedness within and without the profession, and wondered whether teachers' 'moral purpose' needed to be refreshed (Education Council, 2017). The challenge for this study is to identify relevant fields, such as education, that connect kaupapa Māori principles and perspectives of public sector leadership. Charles Royal coined the phrase 'creative potential of mātauranga Māori' (NZQA, 2009). I take this as an opportunity to blend 'traditional Māori knowledge' with 'modern and global knowledge' to create highlevel scholarship in this field of study.

International scholars such as Rhodes (2014) identify academics who have made significant contributions to the public administration and leadership debate, such as Selznick (1984) on institutional leadership, Van Wart (2003) on leadership becoming a specialised area of study, and Terry (1995) on 'administrative conservatorship'. Van Wart's (2003) assessment of public-sector leadership theory also noted the neglect of administrative leadership in the public-sector leadership literature, and that bureaucracies are guided by powerful forces that are largely beyond the control of administrative leaders, making their contributions relatively insignificant (p. 215).

The question of whether public servants should be leaders is at the heart of the publicadministration literature on reinventing government, the new public management, the entrepreneurial public servant, and public value (Rhodes, 2014, p. 102). In many ways, public servants have no choice. Leadership in the New Zealand public sector is embedded in the Westminster system, with a clear and sharp distinction between elected ministers (political leadership), who retain responsibility for general policy and administration, and politically unaffiliated, permanent officials (administrative leadership) (Mulgan, 2012, p. 3). Leadership with political astuteness and ethics is an integral element of the work that senior public servants do (Manzie \& Hartley, 2013, p. 6). The dilemma senior 
public servants face is that of serving their political masters and the democratic process while considering citizens as clients, and they are also expected to lead big and complex organisations at the same time ('t Hart \& Uhr, 2008, p. 5). At a broad level, the three key challenges identified for leadership in public administration are:

- $\quad$ serving the government of the day and the democratic process

- crafting, sustaining, and adapting public organisations

- making government work; delivering public value ('t Hart \& Uhr, 2008, p. 6).

Fairholm (2004) identifies five distinctive leadership perspectives from experience and literature from the past 100 years that are consistent with the fundamental constitutional values that guide and shape the work of public managers:

- leadership as scientific management

- leadership as excellence management

- leadership as values displacement activity

- leadership in a trust culture

- leadership as whole-soul (spiritual).

Fairholm's (2004) contribution is relevant and important for this research. Fairholm (2004) asserts that public managers' perspectives of leadership differ, and Fairholm's research implies the leadership perspective a person holds defines:

- the truth to them about leadership

- the leader's job

- how one analyses the organisation

- how one measures success in the leadership activity

- how the leader views followership (Fairholm, 2004, p. 580).

International scholars such as 't Hart \& Uhr (2008) ask a range of questions about leadership in the public sector, such as 'What does it mean when people say they want better leadership? What does "leadership" really add to the mix of institutions and processes that make up the business of government? How can public sector leaders engage in collaborative leadership within and across sectors in driving policy change?' 
These questions can be equally applied to this thesis. What might be important to find out is: does Māori leadership really matter?

Making sense of Māori narratives involves searching for the underlying meanings as to 'why' this work is important; what drives the need to illuminate Māori aspirations, to reframe conversations, and to champion change. This search for meaning involves leaders and leadership. It requires courage and commitment to explore and to articulate their experiences. Ancona (2005) argues that along with sense-making there are three other key leadership capabilities leaders need in business settings to be successful. First, inventing: creating new ways of working together; secondly, visioning: creating a compelling vision of the future; and thirdly, relating: development of key relationships with and across organisations. The Leadership Framework - developed by four MIT Sloan faculty members, Deborah Ancona, Wanda Orlikowski, Peter Senge, and Tom Malone carries several core assumptions:

1. Leadership is distributed. That is, leadership is not solely the purview of the chief executive officer, but can and should permeate all levels of the firm.

2. Leadership is personal and developmental. There is no one way to lead. The best way to create change is to work with the particular capabilities that you have, whilst constantly working to improve and expand those capabilities.

3. Leadership is a process to create change. Leadership is about making things happen, contingent on a context. Leaders may create change by playing a central role in the actual change process, or by creating an environment in which others are empowered to act.

4. Leadership develops over time. It is through practice, reflection, following role models, feedback, and theory that we learn leadership.

Individuals need to exercise all four capabilities. They must also work with others who complement their skill portfolio. In this way leadership can be shared among multiple individuals. One might plan the future whilst another works with others to invent ways to improve current operations. Thus, leadership is both an individual and a collective capacity (Ancona, 2005). 


\section{Leadership-as-Practice (L-A-P)}

The intersection between kaupapa Māori theory and the emerging theory of L-A-P offers scope to explore Māori leadership as theory and praxis. According to Raelin (2015), the essence of L-A-P is 'a conception of leadership as occurring as a practice rather than residing in the traits or behaviors of particular individuals'. This aligns to the principle of kaupapa - as a collective not an individual endeavour. The concept signals a move away from analysis of Māori heroes and role models towards what occurs in reality and what is practiced. The whānau element is also relevant, as according to Raelin it 'is about what people may accomplish together and is concerned with how leadership merges and unfolds through day-to-day experience'. Again the relational elements, collective elements, and weaving elements appear as precursors for Māori leadership practice. The L-A-P literature resonates with Māori principles and perspectives of leadership expressed in whakataukī (Māori proverbs). For example, the whakataukī 'Nā tōu rourou, nā tōku rourou ka ora ai te iwi' ('With your basket and with my basket the people will prosper') is an expression of collective practice.

The L-A-P movement opens a plethora of research opportunities and a connection between Western leadership and Māori leadership literature encouraging the study of social processes beyond influence, such as inter-subjective agency, shared sense-making, dialogue, and reiterative co-ordination (Raelin, 2015). It is consonant with perspectives highlighting a shared or collective model of leadership (Bolden, Petrov, \& Gostling, 2008; Pearce \& Conger, 2003; Spillane, 2006). Gronn (2002) identified that it is characterised by reciprocal independence (Raelin, 2015). Exploring L-A-P creates the potential to examine practice settings that not only answers 'does leadership matter?' but also 'when does it matter?', 'with whom does it matter?', and 'how does it matter?' These questions are important in contexts within which Māori leadership practice emerges.

Raelin (2015) states that leadership needs to be understood in terms of leadership practices and organisational interventions rather than just personal behavioural styles or competencies. The focus is on organisational relations, connectedness, interventions into the organisational system, and changing organisational practices and processes. This is applicable to this study. Kaupapa Māori perspectives use tikanga and mātauranga Māori and tribal or Māori context to heighten the awareness of the critical interaction 
between intellectual and spiritual sense-making in leadership, creating and shaping ethical and values-driven conduct (Kelly, Jackson, \& Henare, 2014, p. 166)

The connection with kaupapa Māori theory is achieved by establishing whakapapa connections and understanding the context of leadership practice within an organisation - its past, present, and future. Individualistic studies, whilst interesting, offer little value for public servants or government agencies seeking to understand Māori perspectives of organisational life, and what is required is to understand leadership deeply embedded out of context and the challenges that are faced collectively (Raelin, 2015).

\section{Leadership in Context}

Leadership occurs in many public-sector contexts, and there are many variations in terms of what leadership is necessary and why that matters. Crosby and Bryson (2005) argue that personal leadership and what truly matters to you are critical factors. What Māori leadership scholars acknowledge is traditional elements of ancestral leadership identified as 'acknowledging the past' as a critical factor that should be taken into account within the 'core' of Māori leadership studies. Studies on ancestral leadership show how Māori leaders carry their genealogies of leadership into the work they do and how they conduct themselves professionally (Kelly et al., 2014). This element is observed widely. It is common to witness ancestral leadership in Māori contexts, on marae, at hui, or in relation to specific government-Māori issues. Māori leadership practices are necessary to support Pākehā colleagues in these contexts. They are also necessary to support Māori in Pākehā contexts. At times, Māori leadership is necessary when you are the sole Māori person present, the lone voice, and ancestral leadership and knowledge is called upon to provide courage and wisdom.

Crosby and Bryson (2005) identified that the prime skill for leading in context is awareness of continuity and change. The term 'potentialities' is defined as the scope for possible change, the opportunity spaces that may open up (p. 39). Crosby and Bryson (2005) state that by analysing forces of continuity and change and hidden potentialities, leaders may determine whether they are seeking reform or revolution; that is, incremental change or a whole new way of thinking and a dramatic change that is transformational and requires disruptive change in systems (p. 41). 
Kaupapa Māori perspectives of leadership assert and privilege the principles of the Treaty of Waitangi (partnership, protection, and participation) as core values and aspirations. The principles of the Treaty of Waitangi provide a clear statement of intent upon which to establish and maintain engagement between Māori and the Crown. The connection between Māori leadership practice and values becomes visible in the way public-sector leaders behave and express their perspectives and views. Managing this Māori-Crown interface requires not only Treaty principles but also respect for due process and the values of integrity, independence, loyalty, and impartiality (Mulgan, 2012).

Also, Crosby (2010) offers a comprehensive approach to leadership as a 'shared-power' phenomenon that embraces many individuals, organisations, and institutions. This research examines how people who are committed to community or public service over the next decade might lead their organisations, focusing on shared or collaborative approaches to leadership that match the dynamics of a shared-power or no-one-incharge world (p. 70). The concepts of shared power and the kaupapa Māori notions of transformation, collaboration, and legitimacy are critical concepts to explore as the research process unfolds.

\section{International Indigenous Literature}

According to Ryan, the leadership contribution of indigenous public servants to the general work of the public service, as well as specifically to helping meet the needs and challenges of indigenous policy, service, and outcome improvement, is underdeveloped in the literature. A Social Sciences and Humanities Research Council part-funded study on the role of indigenous bureaucrats in Canada, Australia, and South Africa (410-20110493 - Leading from Between: The Challenge and Promise of Indigenous Bureaucratic Leadership) is under way that concentrates on the contributions of indigenous people inside the public sector - indigenous public servants who straddle the two worlds of their traditional communities and their bureaucratic workplaces. Given their unique status as indigenous peoples within Western public services, the research explores what unique leadership insights and contributions these people offer. A comparative approach allows 
for multiple meanings, sites, and perspectives to be analysed to expose similarities and differences - 'we expect there to be diverse views and language of indigenous bureaucratic leadership to emerge both within and between the three jurisdictions' (B. Ryan, personal communication, 15 August, 2014).

In a special issue of the journal Leadership, Wolfgram, Spiller, and Voyageur (2016) aimed to provide a scholarly space for indigenous leadership to explore, among other things, how the experience of indigenous leaders offers new ways of understanding leadership dynamics; and how the study of indigenous ontologies and practices of leadership contributes to existing academic leadership discourse. The special edition canvassed issues related to mana wahine leadership and the concern with acknowledging and enhancing the place of Māori women in society and in making visible their contribution to leadership (p. 327). Evans and Sinclair (2016) highlight the issue of leadership identity from critical research of leaders working against gender, racial, and cultural stereotypes (Ford \& Harding, 2007; Kirton \& Healy, 2012; Nkomo \& Kriek, 2011; Ospina and Foldy, 2009).

The challenge for this study and indigenous peoples is the context of government (kāwanatanga). This is a foreign context for indigenous peoples globally, and for Māori in Aotearoa New Zealand. Cajete (2016) argues communal and culturally relevant forms of leadership are what matter most for indigenous peoples, and indigenous leaders are developed out of a community context of affection, affiliation, and education. Indigenous leadership is about 'we are all related', service to the people, identity of the people, deep desires of the people, vocation, and community (p. 373). This means indigenous leaders have a responsibility to their people, and they must always have the best interests of their communities in mind. Outside of the community context, indigenous leaders are left exposed and operate in environments that do not understand the imperatives for indigenous inclusion.

Kenny and Ngāroimata-Fraser's (2012) position on liberating leadership theory offers a consistent view of indigenous leadership practice, including the idea that it takes different forms based on the changing historical tides - autonomy, imperialism, colonisation, resistance, and renaissance. They quote Ospina and Foldy (2009), who state 
that 'exclusive of addressing context, our theories of leadership remain incomplete, making it more difficult to offer practical guidelines to address the leadership demands of changing organisations in contemporary society (p. 876).

The traditional elements of Māori leadership find a commonality with other indigenous understandings of leadership. The sense of place and the relationship between Papatūānuku and Ranginui, atua Māori, and Māui-like celestial beings in the form of tūpuna connect ancestral leadership forms, including elements of wairuatanga, mauri, tapu, and noa. This is described by Kenny as an aesthetic engagement with the land (whenua) - an intimate spiritual commitment to relationships with all living things (Kenny, 1998). Kenny (1998) expresses the notion of earth as our first embodied concept of leadership. A further idea is introduced that indigenous leadership takes form in the transmission of knowledge and teachings through storytelling, oratory, arts, and traditional practices of all kinds. Kenny argues stories provide powerful bridges that connect our histories, legends, senses, practices, values, and, fundamentally, sustainability as peoples (p. 4).

The small but growing literature on indigenous leadership and public administration recognises the dilemma often referred to as 'living between two worlds' and 'walking between the worlds'. The narrative identifies there is plenty of leadership work to do, and that every context is different, each with its own complexities and challenges. As this thesis argues and Kenny recognises indigenous activists and cultural workers in education, health, government, and a host of other contexts often find themselves caught between what they often call Western values and indigenous values (p. 4).

\section{Gaps in the Literature}

The literature review has explored Māori leadership in the context of public administration. Māori leadership literature is largely reflective of traditional Māori conceptions of leadership and kaupapa Māori. The research is dependent upon experienced Māori academic and public servant leaders such as Sir Mason Durie, Ranginui Walker, Hirini Mead, Linda and Graham Smith, Sir Apirana Mahuika, Parekura Horomia, Hekia Parata, and other kaupapa Māori advocates. These leaders have paved 
the way for Māori researchers to have a go and test their ideas and theories within a research construct that allows us, as Māori, to be Māori, with confidence that Māori methodologies and frameworks may be validated and contribute to knowledge and understanding.

Māori leadership literature is scarce in the field of public administration, and this is exacerbated by the limited attention Western academia have paid to the phenomenon of kaupapa Māori perspectives of leadership and the lack of recognition by government agencies who privilege Western academic research. In the absence of academic literature, I have drawn on the work of the State Services Commission, Te Puni Kōkiri, and the Waitangi Tribunal to identify the critical and relevant issues. I have also explored potential linkages to broaden the Māori leadership perspective by deliberately focusing on the fields of Leadership-as-Practice and leadership in context.

However, there are gaps. It is important to recognise there are differences in approaches to Māori leadership from a gender perspective. Forster, Palmer, and Barnett (2016) state that the discourses related to mana wahine touch on a diversity of challenges, including Māori women's control over their own identities, making sense of Māori women's different realities, describing forms and contexts of oppression that are confronted by Māori women, and celebrating the strength and resilience of Māori women in various circumstances (p. 326). It is also important to recognise the inter-relationship between Māori perspectives of leadership and public-sector perspectives of leadership. This study goes some way to addressing this gap, but it also opens the field of possibilities in the specific areas of diversity, inclusion, and equity. 


\section{Chapter Three: Research Design and Methodology}

\section{Overview}

The broad theory of kaupapa Māori (Smith, 1997) and social constructionism (Crotty, 1998) provide the basis for this qualititative research design and methodology. Kaupapa Māori theory positions Māori ways of knowing as the primary view. To this end, Crotty (1998) calls for 'a unique methodology' (p. 14), and states that 'one can create their own based on who you are, what you want to learn and connecting what you believe about the world' (A.Wolf, personal communication, 21 March, 2014). This chapter sets out the kaupapa Māori principles, ethical elements, research objectives, data collection, and analytical processes for this study.

\section{Kaupapa Māori theory}

The fundamental basis for applying kaupapa Māori theory to this study is evident in the statement made by Graham Hingangaroa Smith (1997) where he emphasises the need for kaupapa Māori principles to be in an active relationship with practice. This premise sets the scene to better understand what is distinctive about Māori leadership practice in the public sector. The assumption is that Māori leadership practice in the public sector is real and it is a lived experience; it therefore exists as a practice or praxis that is appropriate and legitimate within the modern world.

The introductory chapters highlighted the personal dilemma of undertaking research on Māori leadership within the context of kāwanatanga. There are two dimensions of kaupapa Māori that are critical to the research design. First, the cloak of kaupapa Māori is an ethical, valid, and protective philosophical foundation to enable insider Māori researchers undertaking research in the context of kāwanatanga. Secondly, the transforming intention of kaupapa Māori positions this research as an expression of Māori voices and concerns for the legitimacy of kaupapa and mātauranga Māori and Māori leadership within the halls of public sector bureaucracy in Aotearoa New Zealand. The research design reflects the privileging of interpretive tools, such as whakapapa logic and whakapapa kōrero, as a method to accentuate and validate the Māori voice within a setting such as kāwanatanga. 
This research design acknowledges the position of insider Māori researchers who undertake research within a kāwanatanga context and the key risks associated with this approach. Mahuika (2008) states that the greater danger may be that in defining kaupapa Māori perspectives of leadership practice, Māori aspirations, understandings, and approaches to research are reduced to 'simple procedures', according to Linda Smith (2000) this may be 'helpful to outsiders, but masks the underlying issues and is a deeply cynical approach to a complex history of involvement as research objects" (p. 242). I have thought deeply about these aspects throughout the research design process and reiterate kaupapa Māori ethical positions, such as searching for guidance through whakapapa and Te Arawatanga, as critical elements included in the research design.

The theoretical foundations laid by distinguished Māori scholars on kaupapa Māori theory (Bishop, 2008; Pihama, 2001; Rangihau, 1975; Smith, 1997; Smith, 1999) and others validate the approach and set a pathway for inquiry and discovery. Māori academics have identified issues relevant to this study, such as Te Arawatanga (Macfarlane et al., 2014), mana wahine (Henry, 2008; Irwin 1992; Pihama, 2001), tikanga Māori (Mead, 2003; Cram et al., 1999), Māori values (Harmsworth \& Awatere, 2013; Henare, 1988; Marsden, 1992), and conversations on mātauranga Māori (Doherty, 2012; Edwards, 2012; Mead, 2012). Linda Smith (2005) clarifies kaupapa Māori as Māori and tribal ways of knowing in the context of privileging indigenous knowledge (mātauranga Māori), Māori customary practices (tikanga Māori), and cultural values (p. 97). Graham Smith (1990) explains that contemporary expressions of kaupapa Māori pre-suppose that:

- the validity and legitimacy of Māori is taken for granted

- the survival and revival of Māori language and culture is imperative

- the struggle for autonomy over own own cultural wellbeing and over our own lives is vital to Māori survival (Pihama, Smith, Taki, \& Lee, 2010, p. 9).

According to Pihama (2001) kaupapa Māori must be about challenging injustice, revealing inequities and seeking transformation (p. 110). In the context of this research, this means 'why' questions must be asked to understand the perspective, the underlying 
logic, and how perspectives and conclusions are reached. Pihama (2001) also states that how transformation is defined is determined by how the issues are understood, theorised, and engaged (p. 102). Therefore, kaupapa Māori theory opens the door to test assumptions and views, particularly with respect to Māori leadership in a colonising environment. This research needed a framework that according to Tuakana Nepe (1991) derives from distinctive cultural epistemological and metaphysical foundations. Nepe argues that kaupapa Māori is a conceptualisation of Māori knowledge. This is further argued by Linda Smith (1999), who states, 'The concept of Kaupapa implies a way of framing and structuring how we think about those ideas and practices'.

Māori scholars have applied kaupapa Māori theory to a wide range of topics, including education, health, housing, justice and corrections, Māori language, and whānau health and wellbeing (Cram, 2009). They advocate leadership as a role in advancing Māori language, knowledge, and culture as a transformational praxis (Smith, 1997). Spiller and Stockdale (2012) advance the notion that from a Māori perspective, entities, including organisations, are comprised of a complex of spiritually end owed life energies that signify their 'thrivability'; that is, a healthy vital life force that we call relational value, for their stakeholders, including employees, customers, social and cultural communities, and the environment (p. 3). This suggests that an 'added value' or 'Māori edge' is derived from kaupapa Māori concepts such as various dimensions of whakapapa, mauri (life force), mana, wairuatanga (spirituality), and hau (reciprocity), and is embodied in the relationships within and between these dimensions of people, products, and processes (Spiller, Erakovic, Henare, \& Pio, 2010).

Fundamentally, the research design is cognisant that kaupapa Māori theory is derived from and inspired by Paulo Friere's (1985) Pedagogy of the Oppressed, highlighting freedom from colonisation (Mead, 1994, p. 2). The reality within kāwanatanga is to understand that the Māori voice is conditioned by the context within which it operates. The silent voice needs to be freed and awakened to contribute to developing the potential and scope for leadership in public administration. 
First, researchers need to affirm the importance of Māori self-definitions and selfvaluations. Second, researchers need to critique Pākehā/colonial constructions and definitions of Mãori and articulate solutions to Mãori concerns in terms of Mãori knowledge. These dual agendas are intertwined; for example, the critique of Pākehā commonsense makes space for the expression of an alternate, Māori commonsense' (Cram, 2009, p. 34).

Kaupapa Māori theory and indigenous methodologies positions concepts of selfdetermination, the Treaty of Waitangi, decolonisation, social justice, and transformation to the forefront of Māori methodologies. Moreover, Māori scholars have achieved a major goal of creating spaces for Māori and indigenous researchers to explore research fields that would otherwise be culturally unsafe for the researcher and the researched. Smith's (2005) concept of 'tricky ground' is apt for describing the spaces between research methodologies, ethical principles, institutional regulations, and human subjects as individuals and as socially organised actors and communities. The ground is tricky because it is complicated and changeable, and it is tricky also because it can play tricks on research and researchers (p. 85).

To navigate the Māori research space as an insider researcher, the design includes Smith's (1997) intervention principles as critical guidelines and assurance that to be Māori is normal and taken for granted. Te reo Māori, mātauranga Māori, tikanga Māori, and āhuatanga Māori (Māori characteristics) are actively legitimated and validated with the research design.

Smith (1997) highlights six intervention principles for kaupapa Māori transformation. In the context of this study, these principles provide an over-arching framework to ensure that the research is carried out with a context of Māori philosophy. This means the researcher must be fully aware of each of the principles and dimensions and how they inter-connect with each other. Collectively they create a research paradigm that looks and feels Māori, with Māori aspirations central to the research purpose. The principles are:

1. tino rangatiratanga - the self-determination principle

2. taonga tuku iho - the cultural aspirations principle

3. ako - the culturally preferred pedagogy principle 
4. kia piki ake i ngā raruraru o te kāinga - the socio-economic mediation principle

5. whānau - the extended family structure principle

6. kaupapa - the collective philosophy principle.

The principle of tino rangatiratanga - the self-determination principle - is embedded in the Treaty of Waitangi and is considered in terms of mana motuhake (sovereignty and self-determination). Smith (2000) argues that the principles of the Treaty of Waitangi have been co-opted by the government to suit the government's agenda, and defining of the terminology is central to Māori understanding of kaupapa Māori. Tino rangatiratanga is about having meaningful control over one's own life and cultural wellbeing.

The taonga tuku iho principle - the cultural aspirations principle - acknowledges the strong emotional and spiritual factor in kaupapa Māori. Taonga tuku iho, including elements such as mana, tapū, manaakitanga, tikanga, and aroha, are the foundation for Māori leadership. Penetito (2011) describes the Māori world view as follows:

The world is considered value-bound (aroha, manaakitanga). We learn those values from the social world (whanaungatanga/kinship, tangihanga). We internalize them and they become part of us (whakapapa, reo). They cannot be set aside (mana/power and authority, tapū/sacred and prohibited). We come to know the social world as being essentially relativist and where multiple realities are the norm. Everyone has his/her own story to tell and variation is the reality (tikanga).

The principle of ako (learning)- the culturally preferred pedagogy principle - promotes teaching and learning practices that are unique to tikanga Māori. Although more specifically relevant in the context of Māori education, this principle connects kaupapa Māori, tikanga Māori, and mātauranga Māori into a holistic and dynamic space of intergenerational knowledge and learning transmission. It is a term that places importance on Māori histories, knowledge, and language; it refers to the Māori way of thinking, doing, and acting (Smith, 1997). This principle of ako is important because it emphasises that, in the Māori leadership context, mātauranga Māori and Māori values and value systems are inextricably linked (Edwards, 2012, p. 42). 
The principle 'Kia piki ake i ngā raruraru o te kāinga' - the socio-economic mediation principle - addresses the issue of Māori socio-economic disadvantage and the negative pressures this brings to bear on whānau (Māori families) and their children. This principle recognises the role of government agencies to work with Māori to address the key social and economic issues whānau Māori face in their day-to-day lives.

A principle highly relevant to this study is whānau - the extended family structure principle - and the practice of whanaungatanga (family connectedness). Whānau (which also means birth or born) is an integral part of the Māori social structure of whānau, hapū, iwi, and waka. The collective responsibility that organises around whānau cultural values, customs, and practices is a necessary part of Māori survival and achievement. There are many examples in which the principles of whānau and whanaungatanga come to the foreground as a necessary ingredient for Māori education, Māori health, Māori justice, and Māori prosperity. Whānau and whanaungatanga envelope the relational leadership philosophy as a way of being and doing leadership, highlighting holistic theorisations of leadership that examine culture, identity, and the macro-contextual dimensions (Henry \& Wolfgram, 2015).

Kaupapa - the collective philosophy principle - connects Māori aspirations to political, social, economic, and cultural wellbeing (Smith, 1997). Kaupapa is a key Māori term, and has a wide variety of inter-related meanings, notably, 'plan', 'philosophy', and a 'way to proceed' (Williams, 1992). The word kaupapa is composed of two core words; according to Māori philosopher Māori Marsden, 'kau means "to appear for the first time, to come into view, to disclose". Papa means ground or foundation' (Marsden, 2003, p. 66). Royal (2000) defines this interpretation further by stating that kau means to appear and papa is a shortened form of Papatūānuku, which means ground. In his interpretation, kaupapa means 'te kau o Papatūānuku' or the ground that rises into view, or the rise of fundamental values into a person's consciousness (Royal, 2000, p. 4). Kaupapa, as a Māori philosophy, is an important Māori ontology, and is essential to how Māori view the world. 


\section{Research Methods}

Methodologies can be understood simply as the systematic or purposeful ways that we seek knowledge or as the paradigms and knowledge constructs that inform our world views and behaviors and help us design methods and tools that best unlock social discourse, social relations and social institutions, and that capture 'reality'

(Smith, Maxwell, Puke, \& Te Mara, 2016).

The research methods draw on the work of Māori scholars who have positioned kaupapa Māori theory as a platform from which Māori are striving to articulate their own reality and experience - their own personal truth - as an alternative to the homogenisation and silence that is required of them within mainstream New Zealand society (Mahuika, 2008). The research methods are also constructivist from the perspective that that 'all knowledge, and therefore all meaningful reality as such, is contingent upon human practices, being constructed in and out of interaction between human beings and their world, and developed and transmitted within an essentially social context (Crotty, 1998, p. 42). Intertwining the philosophical persepctives focuses the research on engaging with Māori public servants to co-construct and orient efforts toward clarifying, communicating, and understanding Māori perspectives of leadership from the position of lived experiences in the public sector.

The context for this thesis is public administration in New Zealand, and, in that respect, this thesis is situated within a historical context of Crown-Māori relationships and the Treaty of Waitangi. There are two key considerations for developing a kaupapa Māori framework for research within a kāwanatanga context:

- the principles of the Treaty of Waitangi

- the importance of tikanga Māori/Māori values.

This research design incorporates the Health Research Council: Te Ara Tika research framework, which includes the principles of the Treaty of Waitangi and tikanga Māori (Hudson, Milne, Reynolds, Russel, \& Smith, 2010). The framework states: 
The Treaty principles of partnership, participation and protection provide a framework for identifying Māori ethical issues in terms of rights, roles and responsibilities of researchers and Māori communities; the contribution that research makes towards providing useful and relevant outcomes; and addressing inequalities.

(Hudson et al., 2010)

In relation to tikanga, the framework highlights:

The primary indigenous reference for Māori values and ethics are the creation stories which highlight specific relationships deemed fundamental to the sustainability of life.

These relationships are embedded as 'kawa' and provide the foundation for the establishment of 'tikanga'. Ethics is about values, and ethical behavior reflects values held by people at large. For Mãori, ethics is about 'tikanga' - for tikanga reflects our values, our beliefs and the way we view the world.

The Te Ara Tika research framework is based on whanaungatanga, manaakitanga (cultural and social responsibility), and mana (justice and equity), underpinned by a fourth principle, tika and pono (truth and honesty). Tika (truthfulness) and pono (honesty) are implicit within this research framework. Many models of kaupapa and tikanga Māori research and leadership practice have been developed over the years, including Smith and Cram's Community Up model (Smith \& Cram, 2001), Manuka Henare's Koru of Māori Ethics model (1998), and Mead's Tikanga Māori model (2003). Māori research models consistently advocate for elements such as karakia (prayer), mihi (greetings), whanaungatanga (relationship building), and kai (food) to be incorporated into the research process, to recognise and respect participants' contributions and sources of knowledge.

Fiona Cram, Linda Smith, and other kaupapa Māori scholars write about values such as tikanga, manaaakitanga, kaitiakitanga, and kotahitanga and how they provide insights to shape and guide research (Cram, 2009, p. 314; Smith, 2006, p. 12). The research design seeks to reiterate the value and richness of Māori narratives viewed through a kaupapa Māori lens. The dynamic elements that inter-relate with each other require a process of 
sense-making to see from a Māori world view perspective and to understand what leadership might look like in the context of kāwanatanga.

Derived from the range of models are five personal values that, as a Māori researcher, I have applied in this research to guide and inform my behaviour as the researcher. These are:

1. aroha ki te tangata - love and respect for people

2. kia humarie - be humble

3. kia tika, kia pono - be honest and truthful

4. kanohi kitea - let your face be seen; meet face to face

5. manaakitanga - enhance the mana of others.

These kaupapa are common among Māori people. They are the expressions of human behaviour that in Māori terms are evident and practiced in everyday marae settings ( $\mathrm{H}$. Mead, personal communication, 18 July, 2012). As Nepe (1991) stated, this base has influence in the way Māori people think, understand, interact, and interpret the world. Māori academics have asserted the importance of various tikanga Māori concepts in informing their leadership practice.

This research design incorporates kaupapa Māori principles, research objectives, data collection, and interpretive analysis and is underpinned by personal ethical values that guide practice (Cram, 2009). Wānanga (forums), kōrero (conversations), whakapapa (foundation layers/geneaology), whakataukī (proverbs), kaupapa, and tikanga Māori are all applied in the research process.

\section{Research Objectives}

My research question was, 'What is Māori leadership practice and how is it enacted in government agencies?' To answer the research question, I set out to explore the voices of Māori experience and to examine Māori leadership practices that emerge from operating in two worlds. The objectives of this research are: a) to address the gap in literature concerning Māori perspectives of public-sector leadership; b) to identify, 
describe, and elaborate on the critical kaupapa Māori perspectives of leadership within the broader context of public administration; and c) to develop a conceptual framework for considering Māori leadership in a modern post-Treaty settlement public service in Aotearoa New Zealand.

\section{Data Collection}

Kaupapa Māori theoretical perspectives of critical inquiry lead to qualitative research methods for data collection, such as interviews, wānanga, and case study (Crotty, 1998, p. 5). The aim is to illuminate the Māori voice and privilege Māori lived experience as a way of knowing.

\section{Research Interviews}

In 2014, I concluded the first phase of five interviews with senior Māori officials. This included two chief executives, two deputy chief executives, and one senior advisor. This cohort of participants completed one-hour interviews as part of an international comparative study on Indigenous Peoples Experiences of the Public Sector (IPEPS) in New Zealand, Canada, South Africa, and Australia, approved by the University of Victoria and the Australia New Zealand School of Government (ANZSOG). The data obtained from this study included interview transcripts, recordings, and notes, which contributed to the high-level thematic analysis.

The second phase of data collection consisted of a research wānanga conducted in 2016, as well as follow-up interviews. The data included documented outputs from the research wānanga, including notes on large white sheets of paper, recordings, and my own written notes. Nine Māori officials and three non-Māori officials participated at the wānanga. Post-wānanga interviews were conducted with 17 senior Māori officials and two nonMāori public sector chief executives. I decided to undertake post-wānanga interviews, as some Māori officials who were invited to attend the wānanga expressed an interest in the research topic but were unavailable to attend for various reasons. In total, 34 people (29 senior Māori officials and five non-Māori officials) participated in the data-collection process. The data collected from the IPEPS interviews, research wānanga, and subsequent interviews were subject to thematic analysis whereby major themes and subthemes were identified and examined in preparation for further in-depth interpretative 
analysis.

The research process (in particular, the research wānanga) aligned with kaupapa Māori research approaches, and created an opportunity for participants to: a) discuss the kaupapa in an appropriate Māori environment; b) position the research within a kaupapa Māori frame, applying tikanga, and concepts such as whanaungatanga and manaakitanga, into the process; and c) locate the researcher within the research, as Te Arawa, as a peer and colleague as part of the wider Māori officials community, and therefore as an insider and someone who appreciates and empathises with the issues and concerns raised. The research process enabled critical reflection, storytelling, and reciprocity of spirit within the process, aligning with international indigenous research philosophies (Smith, 2005).

Follow-up interviews for participants who could not attend the wānanga were organised to fit in with participants' busy work schedules. Interviews were held in workplaces or at a nearby café. Twelve interviews were audio-recorded and transcribed. For interviews that were not audio-recorded, comprehensive notes were taken. The interviews followed the same structure as the research wānanga, in that an initial outline of the research topic was provided, including the diagram of the two-worlds framework discussed in Chapter Two. This preceded asking the question, 'What does lived experience tell us?' Participants were drawn in to the topic and reflected on their lived experience. As in the case of research wānanga, the participants' voices were privileged by allowing them to free-flow in their thought process and converse with as little interruption from the interviewer as possible. Participants responded well to this approach; in moments of brief silence, prompt questions by the researcher were useful in sparking further thoughts and reflections.

\section{Research Wānanga}

This research used wānanga as a research tool, whereby wānanga are positioned as forums to meet and discuss; seminars; and places where tribal knowledge, lore, and learning were valued and constituted as normal (Families Commission, 2013). The wānanga is an appropriate place where the kaupapa of Māori leadership can be contested and validated. The researcher must underpin the process with an intimate understanding of the context, relationships, the realities, current and historical events, and tikanga 
Māori. The linkages between and across the New Zealand public administration ecosystem, the Māori world, and the topic of leadership must be made apparent to participants. The researcher must be able to articulate how participants relate to the research. The researcher must reinforce their key points about Māori leadership within a framework that references who they are and where they are from. For myself as the researcher, my connection to my whakapapa of Te Arawa, landmarks, kōrero, and tūpuna is critical to identity as Te Arawa, and therefore provided the platform for the wānanga to continue from a culturally authentic base, with integrity and respect.

The research wānanga was held in the Nau Mai room at Te Puni Kōkiri, on Lambton Quay in Wellington. This location was significant, as Te Puni Kōkiri represents the heart of Māori leadership in public administration. Te Puni Kōkiri is the hub of Māori development and Māori policy, and its role is to provide advice to the Crown on Māori issues. As participants arrived, I observed their resonance with the location. The participants who attended have a professional familiarity with each other. They are intrigued by the research topic, and thankful for the invitation to participate. The culmination of these elements is symbolic in that Māori could meet and discuss a kaupapa Māori within a government agency. It clearly showed that Māori have a place inside public administration.

The first wānanga was used to engage public sector leaders to share experiences and ideas of Māori leadership in public administration. The research wānanga process included karakia, mihi, and whanaungatanga - and, of course, kai. The elements of tikanga within a Māori setting, albeit within a context of kāwanatanga, was a natural process for participants. The majority of participants were Māori. The normalised application of tikanga Māori enhanced the wairuatanga (the spiritual elements) to create an appropriate environment for engagement. These practices clearly showed that tikanga Māori has a place inside public administration. The wānanga process uncovered a philosophical urge by participants to support this research project and the researcher perhaps in the hope that it might be a catalyst for change, or at least to provide a sensible Māori leadership narrative that finds resonance with public sector institutions. 
The research wānanga provided a starting point for the research and, in some ways, launched the research project in a public and culturally significant way. The major issue in setting the wānanga date was time. For senior public servants, time is scarce. Making appointments is problematic when you know people are busy, and, similarly, the time away from your own professional duties and the impact that that has must be taken into consideration.

A constraint for insider researchers within the public sector is that you work with the research participants across the public sector, and personal and professional reputations are on the line. Perception, as it applies in Māori leadership practice, continues to be at play even in the research context. Personal integrity and mana needs to be kept intact, for both the researcher and the participants, to respect individuals' confidentiality and the research findings.

The final phase of the data collection and analysis process involved me facilitating a twohour session with 30 Māori staff from the NZQA at the annual NZQA Māori staff network wānanga held at Orongomai marae, Upper Hutt, Wellington on 6-7 May 2017. The wānanga session included some staff who are in Māori-specific roles and some who are in not Māori-specific roles but rather management, operational, and administrative roles. The main purpose of the wānanga is whanaungatanga; to build, maintain, and sustain relationships among Māori staff. The research topics were of interest and aligned with the development opportunities that are offered at the wānanga.

As I was nearing the end of the data-collection process, the wānanga provided an opportunity to test some of my initial thoughts and emerging themes with staff. Staff worked in small groups and engaged in conversations about the themes, and then presented their feedback to the full group. Data was recorded on large sheets of paper, which were later summarised and provided to me. This wānanga was an important part of the process, as it served to validate the research topic and process, and, from the perspective of research participation, and in a reciprocal manner, provide an opportunity for Māori staff at the NZQA to have a say and feel like their perspectives and voices were relevant, as they lived the experience every day. 


\section{Case Examples}

Barzelay (2007) states that lived experience is a powerful teacher (p. 521); hence, the stories of those who have trodden the path of kaupapa Māori-inspired leadership practice are relevant. The research design included case examples primarily aimed at finding deeper understanding of the lived experiences of two individual case studies and one organisational case study of the NZQA. The individual cases were selected based on personal knowledge of individual leadership experiences and career journeys. I was keen to ensure there was one male and one female case study, and I was interested in an alternative perspective from a Te Arawa public servant. Both cases were explored with a view that their lived experience would uncover different but equally rich insights into elements of Māori leadership practice. The NZQA case study was chosen to help me to understand what the NZQA's experience can tell us about Māori leadership in a government agency. I have worked at the NZQA since 2009 in the role of Deputy Chief Executive Māori, and I have presided over the implementation of consecutive NZQA Māori strategies during my tenure. As I am fully aware of and immersed in the experience of Māori leadership in a Crown entity, my experience is integral to my own high-level understanding and knowledge of Māori leadership in public adminsitration. To ensure the robustness of the research, the research was designed to include interviews with the Chief Executive, key staff, and other Māori staff within the NZQA.

The selected case studies stimulated curiosity and a need to drill deeper to understand the reality of what is occurring. This research was interested in the deep meanings, differences, similarities, and nuances of Māori leadership practices, so a full range of considerations were taken into account, such as role and position in the government agency, gender, and whakapapa. Individuals were willing to participate in the research because they were familiar with the researcher. The first two that were asked accepted. A kaupapa Māori approach to research applied a Māori lens - using rangatiratanga, manaakitanga, whanaungatanga, and mana - providing the key dimensions and indicators for the research, yet still allowing the participants to express their own voice and experiences.

The data-collection phase started in 2014 with the five interviews with senior Māori officials as part of the ANZSOG-funded IPEPS project. There was a substantial amount of 
material created as transcripts, case notes, and recordings that was then organised into data-sets ready for analysis. The next section discusses the analytical process and approaches taken.

\section{Data Analysis}

This section explains the data-analysis process. It outlines four main analytical techniques, the tools used, and describes how they align with kaupapa Māori as the critical research lens. The techniques are: a) sense-making; b) narrative analysis; c) kaupapa Māori analysis; and d) comparative analysis. The validation of process is provided to conclude this section.

\section{Sense-Making}

Sense-making (a term coined by Karl Weick in 1995) techniques and the use of whakapapa logic are tools for making sense of the world around. The act of sense-making is discovering the new terrain as you are inventing it. In the very process of mapping the new terrain, you are creating it. The process of analysis in this study needed to be both structured (as in setting out a whakapapa or genealogical map) and iterative and reflective, to make sense of a vast array of ideas, concepts, and perspectives. The data collected was transcribed, and, using whakapapa analysis, emerging themes were identified and then clustered into sub-themes and issues. As the analysis unfolded, there was a constant tracking backwards and forwards between transcripts and research notes, exploring phrases and quotes and the meanings behind words. Behind phrases and words lay an underpinning essence of wairuatanga (spirituality) and sentiments towards whānau and place. As a Māori researcher, cognition of the Māori elements was natural and intuitive and relevant to the research analysis.

The approach makes the connections between actions, experiences, and thoughtprocesses, explaining why, how, and what Māori leadership practices in government agencies are. The data analysis focuses on what occurs and reflects upon how these practices are conceived, authorised, and supported. For explanation and elaboration, whakapapa analysis is used to identify the essences of Māori leadership practice in agencies. 
The analysis examined key themes, in te reo Māori and English, and interpreted how the emphasis of certain words indicated certain meanings and/or patterns. I paid specific attention to the expression of Māori voices within the key quotes from the transcripts. Key phrases and statements are noted where other participants have interpreted their own experience using other expressions. The use of Māori words (kupu Māori) and proverbs (whakataukī) is a major feature of the research analysis. This indicates the nuanced cultural perspective of Māori leadership experiences.

\section{Narrative Analysis}

The second key approach to data analysis involved applying narrative analysis within a kaupapa Māori research framework, connecting Māori public servants as practitioners and research through narrative inquiry (Ospina \& Dodge, 2005). In Ospina \& Dodge (2005), Ewick and Silbey comment that practitioners are a powerful research tool offering a window into 'truths that are flattened or silenced by an insistence on more traditional methods of science' (p.413). Ospina and Dodge (2005) outline three principles;

- narratives as language - a medium of expression - narratives convey meanings intentions, beliefs, values, and emotions that reflect social reality, rather than reflecting an objective reality

- narratives as knowledge - a medium for explanation and learning - narratives carry practical knowing that individuals have gained through their experience

- narratives as metaphor - a carrier of deeper institutional meanings - narratives are constitutive, which means they are not only shaped by individuals, but they also shape individuals (p. 414).

These principles resonate strongly with ethical kaupapa Māori research. According to Smith (2005), indigenous research has a broader purposeful agenda for transformation that privileges indigenous knowledge, voices, experiences, reflections, and analysis of social, material, and spiritual conditions (p. 87). Embedded in these stories are the ways of knowing, deep metaphors, and motivational drivers that inspire the transformative praxis that many indigenous researchers identify as a powerful agent for resistance and 
change (Smith, 2005, p. 89). van Eeten (2007) suggests narratives consist of core units of analysis, the story, text, and focalisation. The story refers to the set of events that are being narrated (p. 252).

The narrative of the Māori leader or Māori expert could be recounted through whaikōrero (Māori oratory), recalling ancestors, landmarks, and events, and relating those historical sources to a time and place to make them relevant for the people. van Eeten (2007) states that text refers to the telling of the story in spoken or written discourse (p. 252). What leaders say - the words, terminology, and phrases - is critical to the intent and direction of the narrative. The narrative of the Māori leader is influenced by how leaders say the words, when they pause, the emphasis, the fluency, the conversational style, and the humour. According to Māori scholar Professor Taiarahia Black, the expression of the words is relevant to the power of the narrative. The tribal framework of knowledge and inter-connections, including experience, learning, and scholarship, validates the Māori narrative (T. Black, personal communication, 30, May, 2013).

Kōrero (words and narrative), rather than numbers and quantitative data, captures and expresses the lived experiences of research participants. Whereas quantitative research begins with a hypothesis and gathers numerical data to disprove a theory, an inductive qualitative approach aims to enhance the understanding of a particular phenomenon by capturing words, statements, stories, and accounts of research participants. Key ideas, perspectives, and concepts can emerge from the data (Mutch, 2005).

The research design aligns Māori philosophical and theoretical perspectives with methodology and methods. The thread that strengthens this alignment is the Māori voice. To undertake a study on Māori leadership in the public sector invites practitioners who are research subjects 'into the research process as people with a perspective and wisdom that are worth hearing' (Ospina \& Dodge, 2005, p.413). In oral tradition, intergenerational learning through oral storytelling is a standard cultural practice that guide the schools of thought of Māori understanding passed down in whaikōrero, karakia, tauparapara (recitals), waiata, and cultural performance. This Māori reality has been constructed through the Māori language and storytelling. It is said 'Te kai a te rangatira he kōrero': 'The food of chiefs is talk'. Narrative analysis offers an appropriate cultural 
method to discover relevant and intelligent insights, as well as opportunities for knowledge creation. Through narratives, Māori are able to chart a future pathway.

\section{Kaupapa Māori Analysis}

There are three aspects of kaupapa Māori analysis that are applied to this data. First, a Māori lens to the data is applied by using whakapapa analysis, as a method of genealogical mapping and layering, to provide a system of logic that structures the way Māori think and formulate ideas from a Māori world perspective (Royal, 1998). This implements the idea of whakapapa kōrero 'as discourse about the relationships of people, things, the environment, and the world' is applied (Smith, 2000, p. 55). Whakapapa analysis helps to ensure the ethical and culturally appropriate gathering and interpretation of data, discourse, ideas, experiences, perceptions, attitudes, memories, and stories (Smith et al., 2016).

Secondly, this analysis examines the data from the perspective of how the wisdom of our ancestors is articulated through whakatauki and is passed down through the generations (Mead, 2003). Over the years, government agencies have adopted whakataukī to weave together their core purpose, vision, and values. Whakataukī are used in the Māori world to make a point and to embellish a kōrero with poetic imagery and drama. The prevalence of whakataukī and other Māori artefacts within government agencies suggests some level of influence is occurring.

Thirdly, this kaupapa Māori analysis incorporates the application of four kaupapa Māori principles. I have used the NZQA's Te Hono o te Kahurangi 'whare ako' framework to position kaupapa as the lens of inquiry and analysis. Te Hono o te Kahurangi was initiated as a result of criticism of the NZQA from Māoridom about its relationship with mātauranga Māori and the lack of validation of mātauranga Māori in the qualification system. I, along with others, was heavily involved in creating the space for an evaluative framework to be co-constructed between the NZQA and Māori. The response to Māori from the NZQA needed to be genuine and sincere, and needed to secure the trust of Māori stakeholders for any solution to be enduring. At the core of the framework are kaupapa that provided the appropriate lens to ensure the NZQA was seeing from the Mãori perspective. The main reason I have adopted four of the kaupapa as analytical lens is that 
the analysis undertaken in a real-life situation between Māori and a government agency mirrors the study objectives to find leadership practices from a distinctively Māori perspective. Te Hono o te Kahurangi provides for kaupapa Māori analysis, and privileges kaupapa Mãori perspectives as the critical lens, without compromising other world views. The four kaupapa Māori lenses applied in this analysis are as follows.

Rangatiratanga can be explained as 'autonomy realized through the enactment of a Māori world-view in response to the aspirations and driving motivators of whānau, hapū, and where relevant, the Māori community and sector stakeholders' (NZQA, 2017b, p.6). The expression of rangatiratanga ensures leadership is demonstrated throughout the process to strive for and create a safe and empowering research environment.

Whanaungatanga can be explained as 'Connecting, fostering, and maintaining relationships based on respect, integrity and understanding for the benefit of all' (NZQA, 2017b, p.6). Whanaungatanga creates a research setting that is relational and acknowledges research participants' whakapapa identity, whānau, and tribal connections and their diverse contributions, as well as unique Māori thinking and reflections adding to the research.

Kaitiakitanga can be explained as 'preservation, guardianship and enhancement of the world and its treasures for the benefit of all' (NZQA, 2017b, p.6). Kaitiakitanga is important to show how kaupapa Māori principles may be applied through tikanga Māori to resolve the rights of Māori and their role in public administration (Marsden, 1992).

Manaakitanga can be explained as 'realised by mana enhancing behaviour and practices for the care of ākonga, whānau, hapū, iwi and community' (NZQA, 2017b, p.6). Manaakitanga empowers research partnerships whose quality is enhanced by the level of the parties' faith and trust in each other (tika and pono). Extending beyond cultural safety, manaakitanga acknowledges the importance of recognising spiritual integrity and Māori philosophy (Hudson et al., 2010). Manaakitanga is fully realised in the context of relationships; through this lens, the quality and value of Māori leadership practice can be examined. 
The concept of mana (respect), along with rangatiratanga, whanaungatanga, kaitiakitanga, and manaakitanga, finds expression in a research framework. In English, mana translates as prestige, authority, control, power, influence, and status (according to the Māori Dictionary website: http://maoridictionary.co.nz). In modern times, mana is a powerful Māori concept that has far greater acceptance and understanding in New Zealand society. When someone has mana, they are respected. When someone does not, they are not. But mana is not something you say you have or do not have. With mana comes humility. Mana is what other people say you have. In practice, a careful selection of research participants with mana is a sensible and logical balancing tool.

\section{Comparative Analysis}

The final aspect of the analysis is to provide a comparative analysis of themes between the two data-sets, the voices of lived experience and the NZQA organisational case study. The analysis aims to identify the similarities and differences between the data-sets: whereas the voices of lived experiences are broad and far-reaching in their scope, the case study provides depth and insight from within an agency construct. The comparative analysis seeks to find themes that might be compelling due to their consistency of agreement and/or interesting because of the diversity of thought.

\section{Validating the process}

The research design elements resonate strongly with ethical kaupapa Māori research. Smith (2005) emphasises the critical role of research in enabling peoples and communities to reclaim and tell their stories in their own ways and to give what others describe as testimonio of their collective herstories and struggles (Battiste, 2000; Beverley, 2000; The Latina Feminist Group, 2001). Embedded in these stories are the ways of knowing, deep metaphors, and motivational drivers that inspire the transformative praxis that many indigenous researchers identify as a powerful agent for resistance and change (Smith, 2005, p.119).

This research design recognises the importance of mana with respect to the sharing of power and control in the research relationship with research participants, whānau, hapū, iwi, or relevant Māori communities who assume the responsibility for the outcomes of 
the project. This also includes acknowledgement of iwi's intellectual property, their knowledge systems, and ownership of research data and guardianship responsibilities in relation to the protection and dissemination of information from the research project (Hudson et al., 2010).

Research is not just a highly moral and civilized search for knowledge; it is a set of very human activities that reproduce particular social relations of power. Decolonizing research, then, is not simply about challenging or making refinements to qualitative research. It is a much broader but still purposeful agenda for transforming the institution of research, the deep underlying structures and taken-for-granted ways of organizing, conducting, and disseminating research and knowledge.

(Smith, 2005).

The data collection and analysis is systematic in the recording and analysis of information. The literature review; documentation supplied by agencies; and qualitative data, including wānanga themes, observation notes, case information, and transcripts associated with each case, are loaded onto computer files. Codes were manually derived from the data and sorted once patterns began to emerge. Themes and sub-themes started to emerge. Case narratives were documented and cross-case analysis were undertaken to analyse similarities and differences as well as relationships between data. Triangulation of wānanga findings, observations, interviews, and documents involved endless iteration and reflection with consistency of Māori experience and voice confirming the validity and legitimacy of this research.

\section{Selection of Research Participants}

The initial list of research participants targeted individuals personally known to the researcher as well as individuals in key positions in the public sector. Research participants were active and personally motivated to provide perspectives and practical examples at the wānanga and during interviews. The richness and reliability of this evidence is grounded in the depth and breadth of experience and the reputation of the Māori leadership practitioners. 
The criteria for selection aimed to ensure an appropriate balance, including:

- a mix of senior-level Māori officials holding tier 3 or above positions

- a mix of Māori male and Māori female officials

- a mix of Māori officials who are Wellington-based and those who are regionally based or focused

- a small number of non-Māori officials

- a number of officials from Te Arawa

- Māori officials in Māori-specific roles and Māori officials in non-Māori specific roles.

The researcher was privileged to explore the wealth of experience within the research cohort of participants. As a total group, they could be described as a leadership group demonstrating Māori leadership practice in the public sector. This group is not alone. There are other Māori officials who are able to offer experience, stories, and insights but were were unavailable. Māori officials who did participate were experienced, qualified, and professionally skilled in both worlds. Participants had deep public-sector experience; most had long and distinguished careers. Most hold professional qualifications, have local, regional, national, and international experience in other leadership environments, and are well connected throughout the Māori world.

The wealth of experience is summarised in the selected statements from the participants' profiles. I collected this information based on my personal knowledge of the research participants' backgrounds and whakapapa. Some people may be able to identify the individuals profiled, but this is not the intention.

- the conduit between what is happening on the ground and ministers

- $\quad$ studied and gained an MBA

- an experienced operator, 'calls it as she sees it'

- at the forefront of the Fiscal Envelope and Foreshore and Seabed engagement with Māori

- professional interests such as the Māori economy, tribal affairs, and Māori leadership

- ' from Te Arawa and knows many of the same people I do' 
- 'took on the role after working for an iwi post-settlement entity'

- military and other overseas leadership experiences

- mana wahine perspectives

- at the centre of a conflict of interest

- 'has seen it all since 1996'

- 'started as a baby policy analyst'

- challenged the status quo

- 'was chief executive there for 10 years and here for eight years'

- 'was excited to get back into the centre and lead'

- 'the best work I saw was in the regions'

- 'I'm probably seen more as a feminist, iwi, radical than public servant'.

\begin{tabular}{llll} 
& MALE & FEMALE & TOTAL \\
\hline Gender & 16 & 17 & 33 \\
\hline Regionally based & 1 & 2 & 3 \\
\hline Nationally based & 15 & 15 & 30 \\
\hline Tier 1 & 3 & 4 & 5 \\
\hline Tier 2 & 6 & 11 & 10 \\
\hline Tier 3 & 7 & 4 & 18 \\
\hline Wānanga participants & 5 & 13 & 9 \\
\hline Interview participants & 11 & 14 & 24 \\
\hline Iwi affiliated & 14 & 3 & 28 \\
\hline Pākehā & 2 & 1 & 5 \\
\hline Under 40 years & 2 & 2 & 3 \\
\hline Part of IPEPS study & 3 & 4 & 7 \\
\hline Part of the NZQA & 3 & Table 1: Selected facts about research participants
\end{tabular}

The table indicates the breadth of Māori experience within the public sector, with a heavier focus on the base of experience from a national perspective working in Wellington and the progression through the high tiers of management, particularly tiers 2 (deputy secretary and deputy chief executive levels) and tier 3 (senior-management level). There is an even spread of voices between male and female; however, future studies could focus on a younger (under 40 years) cohort of Māori public servants. It should be noted that the participant analysis was undertaken at a particular point in time. 
In most cases, the participants started their careers in the regions and worked their way through the system and are now in senior positions based in Wellington. This lived experience is vital to the study.

\section{More than a Thesis}

The level of interest in the research topic highlighted a desire among participants for this research thesis to make an impression upon those in positions of power. There was hope expressed that the research thesis acknowledges and recognises the roles Māori officials play in their public-sector leadership capacities. It was a concern that there is currently no formal system that exists to encapsulate Māori leadership knowledge and the related experiences, concepts, and practices within the context of public administration. The public-sector Māori leadership development practice had been to rely upon one or two senior Māori officials to provide individual perspectives and advice, and to share their personal story as a mechanism of mentoring others. Whilst valuable and rewarding, participants felt a more constructive and enduring process for Māori leadership in the public sector was necessary. Earlier efforts to build public-sector Māori leadership programmes, such as the Leadership Development Centre Maranga Tira Programme, have been discarded and no longer exist. Participants felt that the voice of Māori leadership in the public sector had been silenced and over-shadowed by the dominant Western philosophies and practices in public sector leadership.

\section{A Novel Angle of 'Practice'}

Participants readily accepted the terms 'Māori leaders' and 'Māori leadership'. However, the inclusion of the concept of 'practice' to form 'Māori leadership practice' stimulated ideas of tangibility, action, and reality. In arriving at this understanding, participants felt Māori leadership practice was difficult to describe and articulate. Participants expressed their understanding in terms of how it is rather than what it is. The idea that this thesis removed the focus on the individual as a leader also removed the pressure for participants to have to talk about themselves as leaders. The whakataukī 'Kāore te kūmara e kōrero ana mō tana reka' ('The kūmara shall not talk of its own sweetness') prevailed as a cultural value. 
There were two major challenges for this research. The first was to carefully plan and execute the research process, systematically collecting and analysing data and information and finding truth and validation (Kayrooz \& Trevitt, 2004, p. 4). The second was to address a common criticism of qualitative research: that it is particularly prone to bias and invalidity because 'the researcher' is 'the research instrument' (Hammersley \& Gomm, 1997, p. 3). In both cases, the research design explicitly adopts kaupapa Māori theory to mitigate the risks.

The design challenges and risks are mitigated by researcher self-awareness and an alertness to predispositions to view events in certain ways, and the careful alignment of context, purpose, approach, design, and methods, supported by academic supervision, cultural guidance, and support from public-sector leaders (Kayrooz \& Trevitt, 2004, p. 5). Eppel (2010) cites Riessman's (1993) four approaches to address 'truth' and 'validation'. These are adapted for this research:

1. persuasiveness - is the interpretation reasonable and convincing to other researchers and Māori (ie, is it mana-enhancing to Te Arawa, Māori public servants, and research participants)?

2. correspondence - taking the results back to the informants through the process of wānanga and kanohi kitea

3. coherence - iteration between the local coherence in each narrative, the themes across the narratives, and the global coherence of the researchers re-telling; are the inter-connections between the various kaupapa illuminating a particular view?

4. pragmatic use - by other researchers, agencies, and Māori communities.

As an insider researcher, practitioner, and Māori, I faced a risk of jumping to conclusions: being swayed by personal views or by the way information is presented if there is an affinity with the presenter or perspective, and therefore there is a potential for bias that has the potential to reduce the validity of this work (Kayrooz \& Trevitt, 2004, p. 4). 
Throughout the research process, my stance has been to be careful not to impose views but to reflect upon what has occurred and to use Weick's (1995) 'sense-making' techniques, placing stories into a whakapapa framework that enables us to 'comprehend, understand, explain, attribute, and predict' (Starbuck \& Milliken, 1998, p. 51). If the research process is transparent and honest, it is argued that readers can construct their own perspectives that 'are equally as valid as our own' (Cohen, Manion, \& Morrison, 2000, p.106)

The term 'insider research' is used to describe projects where the researcher has a direct involvement or connection with the research setting (Robson, 2002). As an insider researcher, I am deeply immersed in Māori leadership, and I have an intimate understanding and unique insights into the relevant challenges and achievements, based on lived experience. Positivists challenge insider research, alleging that a 'blurring of boundaries' between the researcher and researched causes invalidity (Jarvis, 1999). Positivists argue that, because of this involvement, the researcher is no longer 'objective', and their results may be distorted. Rooney (2005) states that the term 'insider research' could also be extended to include cases where the researcher is partisan to the emotional/political/sexual affiliations of the subject(s). Examples include feminist research carried out by feminists (Devault, 1990) and gay research carried out by homosexuals/lesbians (Leck, 1994).

There are key benefits for insider research in this study. Rooney (2005) identified that insiders have a wealth of knowledge the outsider is not privy to (Jones quoted in Tedlock, 2000). It is argued that interviewees may feel more comfortable and freer to talk openly if familiar with the researcher (Tierney, 1994). From an anti-positivist perspective, therefore, insider research has the potential to increase validity due to the added richness, honesty, fidelity, and authenticity of the information acquired. The task is to minimise the impact of biases on the research process, to carry out research in consciousness of its socially situated character, and to make the researcher's position visà-vis the research process transparent (Hammersley, 2000). Thus in this case we might use criteria of authenticity (Guba in Cohen et al., 2000) and credibility (Denzin \& Lincoln, 2000), and kaupapa Māori principles of tika, pono, aroha, kanohi kitea, and manaakitanga (Mead, 2003). 
In such interpretive research, Radnor states that 'consciousness that there is evidence to support the interpretation generates confidence in the bases of the researcher's interpretation' (Radnor, 2001, p. 40). From such a perspective, the insider position could be viewed as potentially enhancing validity for various reasons. The insider researcher has valuable knowledge and experience of the research context that outsiders will not have - for example, he/she is aware of internal jargon, legitimate/taboo subjects, internal politics, and so on. When conducting the research, the insider researcher can use this knowledge to obtain richer data (Coghlan, 2003).

\section{The Issue of Ethics}

This section acknowledges the issue of ethics. Undertaking doctoral research as an academic, Māori public servant, and practitioner is a powerful and privileged position to be in (Costley et al., 2010). The systematic and ethical approach to exploring Māori leadership knowledge and insights from the lived experiences of Māori public sector leaders extends beyond a research project. It feels like a parallel exploration venturing into the indigenous Māori experience and narrative but within a context that is counterintuitive to the aspiration of Māori.

As I reflected on the research design task, I considered 'Who I am to do this work?' I considered the Māori lens or perspective I bring, and the question 'How will I represent this topic?' I considered my role in the public sector and the influence I have in my role as Deputy Chief Executive Māori at the NZQA. Moreover, this critical reflection allowed me to consider an ethical framework that would serve this doctoral research well: to act with integrity, with mana.

First and foremost, I take the view of a Māori researcher. In te āo Māori, it is common for people to introduce themselves by saying their pepeha. This is an expression of whakapapa and identity. It says to others, 'This is who I am and this is where I am from'. In many cases, others will respond similarly: they will acknowledge each other and make connections, both personally and tribally. A relationship is formed. In te āo Māori this is known as whakawhanaungatanga (the process of making relationships). Māori scholars such as Smith (1995) state, 'research ethics is at a very basic level about establishing, 
maintaining and nurturing reciprocal and respectful relationships. They require critical sensitivity and reciprocity of spirit by a researcher' (p. 97). My ethical framework must incorporate whakawhanaungatanga as the fundamental basis for relating to research participants and stakeholders.

Research ethics is more about institutions and professional codes of conduct than it is about needs, aspirations or world views of marginalized and vulnerable communities.

(Smith, 2005, p. 96)

The design of an ethical framework needs to ensure a duty of care for the NZQA, and take into account the standards expected by the New Zealand State Services Code of Conduct and academic ethics requirements. Within my personal research framework, the State Services Code of Conduct (2010), as outlined in the document Standards of Integrity and Conduct for state sector employees, is a useful reminder of the general principles for and responsibilities of state sector employees. Similarly, the NZQA Code of Conduct (2007b) shares the same principles and provides assurances to the NZQA Board and Chief Executive that the highest levels of professional integrity and behaviour will be adhered to. However, my research calls upon Māori leaders in the public sector, as research participants, who each have their own unique experiences, needs, aspirations, and narratives. Insights and learning will be shared and analysed in a research environment that fosters and advances Māori leadership and kaupapa Māori. To undertake Māori research with integrity requires an overall ethical framework that recognises all perspectives.

O'Leary (2010) states that absolutely central to research integrity is ethics. As a researcher, you have an explicit and fundamental responsibility to the 'researched' (p. 42). There are legal, moral, and ethical obligations. The general ethical guidelines include: a) ensuring participants have given informed consent; b) ensuring no harm comes to participants; and c) ensuring confidentiality and, if appropriate, anonymity (p.41). The university ethics-committee approval process is a key mechanism to a) ensure integrity of knowledge production; b) promote responsibility towards participants; and c) secure protection from legal ramifications that might arise from unethical research (p. 42). This research abided by the Victoria University of Wellington 
ethics review process, with the completion of a guide for research wānanga participants, and information sheets and consent forms for participants submitted to and approved by the Victoria University of Wellington Human Ethics Committee.

An ethical research framework, as proposed in the Victoria University of Wellington Human Ethic Policy, therefore, includes the principles of the Treaty of Waitangi. Moreover, it must consider building and managing respectful relationships, including a duty of care as an insider researcher, with respect to ethical responsibilities to the institution and professional codes of conduct, and moral and legal obligations. For example, the information sheets and consent forms signed by research participants included statements that any information provided would be kept confidential to the researcher and the supervisor, and that participants would not be identified in my thesis. Moreover, from a kaupapa Māori perspective, understanding concepts such as tikanga, whakapapa, and Māori cultural values provides the tenets and principles for ethical Māori research.

In my thesis, an ethical framework ensures all those who have a stake in the research, including the research participants, employers, wider public sector, academia, iwi, and whānau, can be confident in the research strategy and research outcomes. The kaupapa must speak to the stakeholders so that the research, discovery of new ideas, and articulation of knowledge is accepted and is mana-enhancing. As I reflect upon an ethical framework for doctoral research within the Māori paradigm, the key message to self is to not change who I am. I need to just be myself, live by my core values as guiding principles, take control of the process, and continue to be highly professional. Acting with integrity and living by Māori cultural values, tika, pono, and aroha, is my own personal test.

\section{Summary}

This chapter lays the research foundation for this study from a kaupapa Māori perspective. As the study is undertaken within the context of kāwanatanga, it is important to ensure each stage and process is underpinned by kaupapa and tikanga Māori. The research approach is distinctive within a kāwanatanga setting, as it seeks to meet the high-level principles and expectations implicit within Māori methodogies. The stages of 
data collection are elaborated on to reassure the reader with a sense that not only has the process been authentic, engaging, and respectful, but also the process is of itself a demonstration of Māori leadership practice.

The analytical framework for this study has been explained in some detail to ensure the layers and tools for analysis are understood. The first stage applies sense-making techniques, such as whakapapa logic analysis, to help clarify and set out the data in a structured format. The second stage involves the critical aspect of analysing and interpreting the data to ensure the Māori voices of lived experience are heard. The use of Māori methods and tools, such as whakataukī, to understand the power of the narrative, and kaupapa Māori principles such as rangatiratanga, manaakitanga, whanaungatanga, and kaitikiatanga to examine Māori perspectives, is justified.

The research participants are critical to the study, and this chapter substantiates the fact that this research can be said to rest upon the deep lived experience of Māori who have worked in the public sector. As an insider researcher, and Māori, I too am part of this research study. This fact means there were challenges, risk mitigations, and ethical considerations that needed to be addressed to ensure the research process was undertaken with confidence and high integrity. This chapter acknowledges the risks and ethical issues and establishes a firm foundation for the implementation of this research. With the research design and methodology having been set out, the next chapter discusses the findings from the research on the voices of lived experience. 


\section{Chapter Four: What do the Voices of Lived Experience Tell us of Leadership?}

\section{Introduction}

This chapter presents two sections of key findings, themes, and sub-themes that emerged from the research. The two research wānanga, series of interviews, and critical observations produced documented outputs, including transcripts, recordings, notes on large white sheets of paper, and my own written notes. The first section provides a description of the key findings from the analysis. The headings indicate the key messages taken from the data to emphasis the Māori voice of participants. Each theme is described and elaborated on. The voices of lived experience are amplified by direct quotes taken directly from transcripts and materials. These quotes illustrate what it feels like to be Māori walking in two worlds and the Māori perspective that shines through the research. The second section of the chapter outlines two case narratives, to elicit deeper insights into distinctive Māori voices, from Te Arawa tangata (Te Arawa male) and mana wahine (Māori female) perspectives.

The identities of all individual participants are protected by phrasing the findings in a collective voice to ensure a focus on the key themes and sub-themes. All quotes that come directly from the research wānanga materials and interview recordings are kept in context. The narrative analysis identified aspects that are distinguishable as Mãori leadership practice concepts and indicated similarities and differences with other conceptions of leadership in public administration.

\section{Section One: Wānanga and Interview Findings}

This chapter discusses research participants' responses to and perspectives of Māori leadership practice operating in two worlds. The chapter explores how Māori officials' views have been shaped by their personal lived experiences including their experience of actual events, working in specific contexts, and length of service in the public sector. The research identified a range of themes and sub-themes relating to how participants have survived and what issues they have had to navigate in the process. Their responses are based around two key themes: first, understanding the reality of space and context, recognising that the tension of operating at the two-worlds interface is underpinned by the conflict between rangatiranga and kāwanatanga and the Treaty of Waitangi, and 
secondly, the link between kaupapa Māori and mātauranga Māori, and building social capital and improving outcomes for Māori. The over-arching theme of reality of space and context is discussed; followed by a discussion of three key sub-themes and issues relating to leadership whilst walking the two-worlds tightrope.

\section{Key Theme: Reality of Space and Context}

Understanding how Māori public servants experience working in the public sector sets the scene for understanding what underpins Māori leadership practice. The two-worlds model (shown in Chapter Three) was presented at the research wānanga and interviews, and the model resonated strongly with participants. The model is a simple representation of the key elements that reside within rangatiranga and kāwanatanga spaces. Participants conveyed a strong sense of 'yes that is it'; we recognise those interfaces exist and that is where our experience is located.

Most of the research wānanga participants subscribed to the notion that the two-worlds context is a space in which deeply held concepts of rangatiratanga and kāwanatanga clash. Pākehā participants acknowledged that only Māori would really understand this aspect. As part of the wānanga session, participants worked together in small groups to discuss the two-worlds concept. One group described kāwanatanga as the highly organized and hierarchical bureaucracy of public administration'. They described rangatiratanga as 'the organic collective system of leadership within the Māori world'. The research wānanga participants were asked to write key words that would describe the two-worlds interface. Words recorded were 'tension', 'conflict', 'compromise', and 'confusion'. Participants discussed that inevitably colonial history, institutional bias, and ambivalence towards the Treaty of Waitangi create a space characterised by tension. That is the reality.

Cognisant of the contextual reality of operating at the interface of two worlds, participants were aware of the dynamic interplay that continuously occurs. Participants spoke of the challenge and at times, struggle for Māori officials. Māori officials need to tread carefully as they navigate different spaces. Participants reinforced that as a Māori official you must be fully aware of how what you say and how you say it impacts on others. In some cases, even your presence within a space raises eyebrows and tension. 
Participants emphasised that Māori leadership practices within these contexts require critical skills and balancing tools that create an environment for discussion and dialogue to occur in an equal and fair manner.

The research participants were acutely aware of their role and responsibilities within kāwanatanga, including the requirement to understand the machinery of government and the State Services Code of Conduct for public servants. Participants considered that for Māori working in the public sector certain areas of tension arose, including:

- balancing personal commitments to Māori and iwi priorities

- others' attitudes towards the Treaty of Waitangi

- the systemic failure of government to address socio-economic disparity for Māori

- the lack of authorisation to contribute to better outcomes for Māori

- the perception of favouritism

- the perpetual silo behaviour disabling and dis-enabling whanaungatanga.

Yet, despite these tensions, the research participants felt confident in this context. There was a very mature outlook and a positive intent to make a meaningful contribution to leadership, Māori development, and public service. Recognition that the two-worlds interface exists caused Māori officials to reflect on their leadership stance within public sector environments. Participants reflected a view that what really occurs is visible when agencies give effect to the principles of the Treaty of Waitangi, when agencies respond and act to the needs and aspirations of iwi Māori, and when agencies legitimate kaupapa Māori. An implicit goal emerged that participants recognised as the need for Māori officials to demonstrate leadership to build trust and confidence in the ability of the Crown and government agencies to work effectively with Māori.

The next section discusses each of the sub-themes that emerged from the voices of lived experience that related specifically to the over-arching theme of 'Reality of space and context'. 


\section{Recognise the Forces at Play}

Participants acknowledged that there are various forces at play that occur beneath the surface when government agencies interact with Māori. Participants were very aware and cognisant of the political dynamics occurring around them. There was a perspective that, as Māori working for the Crown, you are perceived to be different to others, and managers and colleagues have different and, in many cases, low expectations of you. The Māori-world perspective is that you are a government bureaucrat and have lost Māori ways of thinking. The key leadership challenge is to recognise those forces and develop strategies and practices to address those challenges. As one participant noted, 'Māori public servants have to withstand the criticism against you from your own and the way they see it is your mind has been infiltrated by Crown thinking'.

The analysis raised issues that are grouped into the following categories:

1. coping with bias and mistrust

2. dominant culture

3. conflicts of interest

4. crossing the bridge.

\section{Coping with Bias and Mis-trust}

Participants reflected on the fact that Māori officials face an underlying force of institutionalised bias, which they argued still persists in modern public administration. Participants acknowledged that how it is felt has shifted with time, and that it is not as deliberate as it used to be. However, the view was expressed that there exists an underbelly level of racism that is 'fed by the machinations of middle New Zealand, political advisors, and media' which was termed 'micro-aggression'. In the participants' terms, 'micro-aggression' refers to the subtle behaviours, attitudes, and negative predispositions toward Māori that operate as a constant reality. Participants recalled that what this means is that, as Māori, you end up operating in a way in which you do not overstate the significance of the Treaty of Waitangi, promote kaupapa Māori, or raise Māori issues for 'fear of being cut down'. 
Participants commented that what they saw occurring within Māoridom was 'more Māori mistrust of each other, created by the Crown'. Participants pointed to how the Treaty of Waitangi settlements mandate process created divisions among whānau and hapū that were so damaging they could be irreparable. Moreover, it felt like government was 'less interested in Māori views and more interested in economic models'. Participants reflected that the role of government "brings a culture of its own and brings a culture of mistrust, with an over-emphasis on risk'.

\section{Dominant Culture}

Participants identified that the key force at play for Māori working for government was the absolute power of the agency and the institution of government and the way the minds of the dominant majority were wired and framed. This created the realisation for participants that to be successful in the dominant Western culture you have to be the same as everyone else. Participants raised the question of sameness as an issue of survival: how, as Māori, are you able to survive in an institutionalised culture? One research participant commented that 'It became very difficult and challenging to be yourself', and that this had the effect of a person's 'becoming the same rather than being different'. This participant stated that 'What is valued in the organization is critical to understand, otherwise leadership tends to be more of the same'.

Participants raised pertinent questions about Māori leadership practice in public administration - is it one and the same or is it different? Is it different because of the added dimension of Māori culture, or does the dynamic of the organisation drive people to a place where the organisational culture is such that they just think the same? The participant quoted above, 'Therefore, it is not diversity of thinking you are getting, but you just look Māori'.

Participants reflected that, as senior Māori officials, you need to be very conscious, aware, and pro-active. Participants said they would often find themselves providing advice, explaining, justifying, or defending the Māori position on policy issues, Māori staff performance or behaviour and the Treaty of Waitangi. Sometimes that was your role, sometimes it was not, but you found yourself in that role because you were 'the brown 
face in the room'. The key leadership practice was to be present, be authentic, and demonstrate a high level of diplomacy.

Participants said they were very attuned to the Māori views of the Crown based upon their personal encounters with the mamae (the hurt and pain) and the way Māori have been treated by the Crown. They made statements such as 'You have to be seasoned, tough and resilient.' One participant recalled a story of attending Waitangi Day at Waitangi and protestors yelling 'kūpapa, kūpapa' (traitor). He said: 'I didn't feel ashamed, in fact, I think you are an idiot, you have no idea what I've worked on in my life'.

The branding of 'kūpapa' is a burden to bear for Māori officials. The term has derogatory connotations, and historically referred to Māori who work with, for, or alongside the Crown 'as traitors'. The modern use of the term is an insult: it impacts on you personally and puts your whānau at risk of antagonism and ridicule. As a Māori official, you call upon your professional leadership capacities and authentic self to withstand the pressure of conflict, in a way that keeps your mana intact and also the mana of others. In practice, participants remarked Māori officials would make conscious decisions concerning if, when, and with whom they engage. One participant commented, 'I would stay away from the Treaty or else you set an expectation and they see you as more favorable to them, it's harder for them when they ask questions.'

Participants commented they would opt out of working in the Treaty area, preferring to apply their skills in productive areas, working with whānau and making a difference to whānau lives. One participant asked the rhetorical question; 'Do you feel part of the organization, or do you feel you are the Māori?' Another participant pointed out; 'It can be a lonely and frustrating place to be.'

One participant commented that the experience of the working within a dominant culture feels like the fragmentation occurring with Māoridom between iwi and hapū is mirrored in the public sector. The lack of whanaungatanga and the lack of support by the system for Māori public servants plays out in Māori public servants making unwise decisions, and 'making things fake'. Māori public servants have feelings of being isolated and lonely in their roles, and there is no support infrastructure in place. This is a major challenge in 
a modern public-sector environment. The context of kāwanatanga is not a new concept, and is well understood by participants; however, there are very few forums to discuss how Māori officials feel about this. According to one participant, 'We need a recalibrated relationship model and context'.

\section{Conflicts of Interest}

The experience of managing conflicts of interest emerged throughout the research. For one participant, the perception of conflict of interest had arisen several times. In this participant's story, a Māori official was working at the interface with iwi leaders and advisors co-creating policy in the areas of Treaty rights and interests. Less than halfway through the programme of work, the Māori official was nominated to stand for the iwi rūnanga (tribal council), placing the individual into a governance role as trustee as well as working for the Crown. There was a long debate between him/her and the chief executive over whether he/she was successful, he/she would have to stand aside from the government role. When the extent of the trustee role was teased out, it became apparent that there would be no benefit to the iwi to have him/her as a trustee; however, there had been a perception that the iwi would benefit more than other iwi and the Crown would be seen to be favouring that iwi. In the end, the participant said, 'I had to resign'.

Soon after the resignation, he/she said, 'another Chief Executive rings up and has created a role for me'. The agency also had an iwi relationship with the same iwi, including an investment plan to produce resources, but for this chief executive the conflict could be managed and risks mitigated. The situation highlighted that, as Māori in the public sector, 'we carry more risk as a consequence of our whakapapa' and 'we carry a perception of favoritism that no other public-sector leader has to'.

The participant concluded the story by saying the conversation with the Chief Executive was not a sophisticated one of what whakapapa brings, what networks and connections bring, or how we can facilitate to influence, but rather a conversation of potential conflict, contest, and challenge, and 'who would be derailed?' According to the participant: 
there is no personal benefit in such conflict of interest situations, and there are experienced Chief Executives who are confident in managing it - other less experienced public-sector leaders get scared, nervous and over-react because they are not aware.

Throughout the research process, a theme was emerging about the need to take ownership of the Māori space and to facilitate the entry of Māori ideas into the kāwanatanga space. Engagement practices were deemed to be critical, as there are nuances around knowing how to speak to, navigate, and influence a process. The participants added there were gaps across the system in knowing how to traverse Māori thinking, to understand and operationalise Māori values, and to triangulate with other forms of evidence. This identified a specialised area and that, as non-Māori are unable to traverse these Māori spaces, Māori public servants must step up, as leaders.

The experience of working in the public sector and stepping up continues to be challenging for Māori public servants within government agencies. Participants reflected on the need to be confident in your role, knowing how you fit in the public sector, and being secure in your relationships with others. The negative element that deters Māori from stepping up is feeling like you are the sole advocate or champion for a Māori view and, also, the extent to which your advice or view is taken seriously.

A strong theme emerged about the legitimacy of Māori voice and input into the policy process. Participants felt that 'without an ability to influence policy, we are just wasting our time'. Participants spoke of 'having to bend the rules to create an even playing field'. The practice included 'bringing in Māori experts, people with mana, to influence'. Māori public servants would go beyond the call of duty to ensure the practices and processes of engaging with Māori and rightful access to policy decision-makers were in place.

The experiences continue to be challenging for Māori public servants, as managers and colleagues have unrealistic expectations. One participant said, 'I think there is a greater expectation on you from your colleagues that you are going to be that voice'. The experience of policy papers that 'come to the Māori unit at the last minute' continues to fuel the debate about legitimacy. The sentiment went further 'there is still no structural guarantee that Māori issues would be taken care of'. Notwithstanding the context and 
situations Māori officials face, participants identified ownership of the interpretation of the context as a critical position for Māori leadership practice.

The research identified that Māori leadership is an educative practice. There was an emphasis on the role of providing translation to others about Māori concepts, ideas, language, and philosophy. Participants described this experience as being both a burden and an opportunity. Participants felt the pressure of expectation to explain to others what Māori concepts mean. They also viewed it as an opportunity to share their culture with others. Safety emerged as a sub-theme, emphasising the importance of remaining culturally safe and of being confident and comfortable in your cultural identity. Confidence stemmed from being connected to te ao Māori. Whānau upbringing and life circumstances were identified as big factors in determining how connected and, therefore, how confident Māori public servants were in sharing knowledge and educating others.

The research participants acknowledged perspectives from non-Māori participants. Specifically, the point was made that as non-Māori, they do not have this insight of the two worlds. I heard this perspective again during the follow-up interviews, where it was stated, 'parts of the Māori world-view will resonate if that is the space and context you are in. However, Māori have this innate understanding of ethnocentricity. Pākehā don't unless it is confronting them'.

Participants shared their experience that working at the interface is 'an explicit interplay of hegemony and interpretation of the rules and accountability'. The dominance of the Westminster system is entrenched to an extent that agencies and leaders move to protect the immutable core of hegemony. This creates an environment whereby 'Māori play on the edges of public administration but not in the middle where it matters most. Unless, of course, if it is a kaupapa Māori, then they are happy to leave it to you to lead'.

Participants felt that beneath the surface is a tactic to pacify and please Māori by allowing Māori to play with some resources and cultural protocols and to initiate some projects but not to penetrate the heart of the decision-making process. 


\section{Crossing the Bridge}

The statement 'crossing the bridge' was commonly heard through the research. This statement is used to describe a Māori public servant walking in two worlds, and implies there is an imaginary philosophical bridge that needs to be crossed between the Māori world and the kāwanatanga world. The location of the Māori public servant at the interface is analogous to the gate of the bridge. Confounded by the dilemma - 'to be Mãori and work for Māori' or 'to be Māori and work for the Crown' - they wrestle with questions such as who do I serve? Where do my loyalties lies? Who am I ultimately responsible to?

Six of the research participants survived the disruptive period of the 2004 Foreshore and Seabed hīkoi and the infamous Don Brash 2004 Orewa Rotary Club speech. Participants discussed the events of the Foreshore and Seabed hīkoi as defining moments for Māori public servants. The hīkoi forced Māori public servants, particularly those working in central agencies in Wellington, to question whether working inside kāwanatanga was the place for them. The narratives were shared with a deep sense of emotion and reflection. For example, one participant arrived at the conclusion that 'The only way to keep safe is to keep the two worlds very separate'.

The scenario in 2004 crystallised what it meant to work for government and be Māori, and the research participants felt the impact. The Foreshore and Seabed controversy and hīkoi gripped the Māori world and demanded national media attention. This issue was like no other in modern Māori history, and cast a new player on the New Zealand political scene: the Māori Party. Furthermore, Don Brash's speech halted Māori policies on the basis of Pākehā discontent with what was described as 'special treatment for Māori'. This felt like a double blow to Māori working inside the system. Everything they worked for and believed in was being challenged. It affected them deeply.

Participants recalled the impact these two events and subsequent government proposals had on them personally as Māori public servants. The government stepped back from front-line services and Māori funding programmes, and Māori public servants were left questioning whether they had a place working for the government. One participant spoke for the first time about her experience and its impact on how she now operates. 
I won't share any of my knowledge and bring any of my networks into the public-sector life, and I am now very clear about that. It is just too compromising to walk in two worlds. The fundamental driver of my decision is the result of my experiences, particularly the Foreshore and Seabed experience and watching that happen while working for the Ministry. I offered my resignation. Then I watched the Orewa speech and it was extraordinary. The public sector would then purge its Māori programs. Many were hard fought for and now for some reason it was not OK. This was a souldestroying experience where I saw whānau relationships compromised, damaged, and in many ways, I had given up on good governance in the public-sector space.

Participants said they felt compromised, and did not feel comfortable. Although not directly involved or a decision-maker, by association, as a Māori official you were part of the government proposals. One participant commented, 'Whānau didn't want me to work that day. I recall a moment being Māori and working for government could have toppled at $10 \mathrm{am}$ that morning. I left work and went to the marae to find a portal to be Māori.'

Māori officials felt the experience of these events within the respective government agencies they worked for. Another participant commented:

the Don Brash speech just blew it to bits in this organization. What I experienced was our organization completely pulled back on any kind of programs that were specifically focused on Māori ... we are still trying to come back from that and so in our history that was quite damaging.

However, under the strain of coping to be Māori and working for the government, Te Puni Kōkiri opened its doors on Lambton Quay to protestors to offer a place to rest and to have a cup of tea. In the heat of controversy, there was still a place for old-fashioned hospitality or manaakitanga. Participants felt that 'if the system is slightly legitimate, then we would take care for the people for whom we exist - without manaakitanga, institutions have no right to exist'.

Participants referred to this period in their career as emotional. They had to make a clear choice - work for the Crown or not. The Māori voices of experience in this research clearly 
articulated that problems occur for Māori public servants if they have not made that choice. They must be clear about their purpose and what they are trying to influence. This requires a high level of consciousness, reality-checking, and understanding the obligations of working for the Crown. The senior Māori officials who were interviewed were unequivocal about the modern positioning for Māori public servants. This was enunciated clearly by one participant, who commented, 'The best thing you can do for Māori is to do your job properly. If you want to work for iwi, go and ask iwi; but while you are paid by the Crown, you work and you are the Crown.'

The transcript continues, 'It seems a logical statement, but it wasn't. It was a big argument ... then during the restructure, a person wrote a submission for iwi against changes at the Ministry and couldn't understand why I was annoyed. I had to explain but he didn't get it'.

Another participant commented, 'Am I crossing the bridge and am I going to defend the government if something goes belly up? That's the test point. Are you ready to defend? If you are not sure, then you probably haven't crossed the bridge'.

\section{Key Theme: Māori Perspectives}

\section{The Treaty is important to me}

The participants confirmed that the fundamental cornerstone of the relationship between Māori in public administration is the Treaty of Waitangi. The Treaty of Waitangi is important to Māori officials, as it provides legitimacy of 'place' within public administration and within te ao Māori. One participant said, "There is something else that allows you to be here, the Treaty of Waitangi'.

There were very strong views with regards to the impact of the Treaty of Waitangi on Māori leadership practice. The overwhelming theme was the importance of the Treaty of Waitangi within the context of good governance, participation, and decision-making between Māori and the Crown. Participants noted a few examples of Māori partnerships within individual agencies; however, the Māori perspective and Māori voice in policy development and decision-making is not embedded in a system-wide approach, and, 
therefore, there is a strong view the public sector has work to do to fulfil the aspirations and intent of the Treaty of Waitangi. There is a strong sense of personal responsibility among Māori officials to ensure that the agency they work for considers and meets Treaty obligations. What have emerged in recent decades are variations in Māori strategic frameworks and Māori policies designed to improve outcomes for Māori and to ensure that government agenices meet Treaty obligations. Participants noted that where there is positive and pro-active leadership demonstrated by agency chief executives, there is visible acknowledgement of the place of the Treaty of Waitangi and deliberative approaches to Māori engagement and leadership practice.

With respect to the place of the Treaty of Waitangi in public administration, participants emphasised how important it was for Māori in the public sector to understand the machinery of government: As one participant commented, 'To operate at the centre, what you have to have is the machinery of government'.

Participants were keen to make the point that Māori working in the public sector are aware of the role and place of public servants. They reiterated that Māori as public servants do understand their responsibilities to ministers and as senior officials are more conscientious about the obligations and the role of public sector leadership.

'The public service code of ethics is a bedrock for anyone working in government, and Māori more than anyone understand this.'

'The ultimate chain of command is the Minister.'

(Research participant)

One participant, who had recently re-entered the public service after working for iwi, said:

The system actually doesn't care much about how much you know about te ao Mãori - it is interested in writing, debate, legislative clauses, cabinet papers. I under-estimated how it is a system. Because you know te ao Mãori doesn't mean you'll be effective.

(Research participant) 
The research emphasises that Māori leadership practice is both a learned and lived experience, and the capacity to innately understand how statutory and Treaty responsibilities are integrated is a unique capability. The quote above illustrates the struggle and the tension, and how important it is to get to grips with the machinery of government. You live it, you learn it, and life experience brings you to a point where you can bring that experience to bear and give sound, free, and frank advice.

\section{Leading with a Bicultural View}

The participants articulated that Māori officials are well equipped to provide leadership at the interface, as they naturally apply a perspective of rangatiratanga, and an equally cognisant kāwanatanga lens. As previously discussed, non-Māori officials have access to one lens - a kāwanatanga lens. The application of the dual lens is an intuitive capacity that intimates Māori officials have an innate bicultural view and pursue bicultural outcomes.

The research identified that tensions within the context of public administration arise due to 'fundamental differences in understanding of the Māori world as an entity of people in the form of whānau, hapū, iwi, and waka'. This collective system is based on the structure of Māori society, as opposed to individual persons, such as patients, beneficiaries, students, or prisoners. The tension becomes apparent because collective Māori groupings have rights and interests, and the entity of people and the inherent structures, whether traditional or democratic, give rise to issues of agency and therefore mandate in terms of who speaks for whom. The structure and power of government imposes models of individualism upon collectives to a degree where whānau, hapū, and iwi are obliged to rearrange and reconstitute themselves in such a way so government will deal with them. Participants lamented that this has led to severe consequences and damage to the fabric of Māori society and relationships between each other.

Participants raised questions about the legitimacy of Māori knowledge, and who determines and who decides what legitimate knowledge is. Participants struggled with the lack of recognition and validation of Māori concepts and practices and therefore a lack of ability to contribute to organisational and policy discussions in a meaningful and respectful way. The participants understood that the dominant system of bureaucracy 
reinforces a power dynamic that privileges Western forms of knowledge over Māori knowledge, and that this is an ongoing tension Māori public servants grapple with. One participant shared her experience in a policy meeting, where it was said: 'we would expect you to say that 'cos you are the Māori agency so now let's move on and has anyone got some real evidence?' She continued, 'The process to make policy is fundamentally flawed - because it only focusses in on the analytical and logical steps - it is that logic that forgets the empathy and reality.'

Another commented, 'The dominant logic in government organizations is based on western culture, it is not based on whānau or tikanga or kaupapa. People make decisions that are in the western culture mode.'

The tension reinforces a reality for Māori that government systems of health, social development, education, and justice have not served Māori well, as the statistical profiles tell us, indicating long-term and sustained systemic failure; in addition, as a public sector, we continue to repeat and perpetuate failure for Māori. Participants conveyed the notion that kaupapa and mātauranga Māori can be recognised and legitimated only if Māori as Māori public servants 'speak up'.

One participant suggested 'the key answers are rooted in indigenous knowledge.' The quote highlighted a firm belief that Māori solutions to Māori problems are to be found within the Māori world. However, leading with a bicultural view also requires one to be open to other experiences, prejudices and alternative forms of knowledge. Participants acknowledged they had a role to articulate Māori ways of knowing and input into the policy-making processes and thereby create the reality of mātauranga Māori within public administration.

\section{Tikanga and Kaupapa Māori}

Participants were unamimous in their perspective that the practice of tikanga is hugely important. Participants articulated that despite the issue that Māori voices are not heard within the dominant Western paradigm, tikanga has a place and space. The dynamic nature of tikanga is flexible to embrace, respond, and create innovative solutions and 
opportunities. Participants acknowledged that within public administration in New Zealand elements of pōwhiri, waiata, haka, taonga, toi Māori (Māori art), karakia, whakapapa, rāhui (temporary ritual prohibition), and many other elements have a rightful place. Each element is unique and has its own deep and rich epistemological foundation, experience, history, and narrative, and there is a Māori leadership element that enables the enactment of tikanga practices.

Participants reflected on the historical case with the Department of Corrections and the debate about whether women sit behind or in front of the men or on the paepae (orators speaking platform) (New Zealand Herald, 2006). Participants echoed disappointment and frustration that important elements of tikanga Māori were reduced to a debate of who sits where.

... in Wellington, kaupapa Mãori is inflexible. It becomes a codified regime, more focused on the symptoms rather than the 'being of kaupapa'. That way of life doesn't exist. It is codified to karakia, pōwhiri, waiata, and what you get is people nervous about complying.

In one example provided, days before an important signing of a memorandum of understanding with a key Māori stakeholder forum, a group manager (a Pākehā) rang the Māori advisor to say, 'have a taonga ready to give the stakeholder group'. Little thought was given to the occasion, the people involved, or the kaupapa (purpose) of the signing. The Māori advisor was very keen, however, to ensure there was a taonga for the occasion. His Pākehā boss had told him to do it. Politically, the giving of a taonga would potentially muddy the waters with the stakeholder group. Whilst on the surface it seemed a good cultural practice to give taonga, below the surface the relevance and significance of giving a taonga and the process of giving and receiving the taonga were more likely to cause further consternation among the parties. The Māori advisor knew this but did as his boss had asked him to do. Instead, the Māori advisor was more concerned about appearance and creating a façade that would make both him and the organisation look good in front of iwi. 
This example shows that the Māori leadership space is tricky; there is a tikanga for everything, and tikanga requires a deeper understanding and consciousness within leadership practice, for without this, individuals working in the space can get into trouble.

'You don't want to look bad in front of iwi, be a sellout or kūpapa, and therefore make iwi more important than the organization I represent; this plays out in belittling behaviors, poking fun at the Crown when you are the Crown.'

'Māori public servants get too hung up on schizophrenia of two worlds. It is the perception of other people that guides our tikanga behaviors and practices.'

(Research participant)

The research found tikanga and kaupapa Māori are important for Māori who work in the public sector. Participants consider tikanga and kaupapa Māori as normal and flexible. They live, work, and adapt as the context requires. Moreover, tikanga and kaupapa Māori make an important and relevant contribution to other leadership and organisational environments.

\section{Space for Māori voices}

The most dominant theme to emerge concerned the need to create space for Māori voices inside kāwanatanga. The experiences of Māori officials provided a level of confidence that Māori voices were informed by mātauranga Māori and were appropriate and relevant in a public administration context. Uninformed voices were counterproductive to kaupapa Māori intentions. Participants were adamant about the place of kaupapa Māori in public administration and recognised that without senior Māori leadership, it was difficult to influence and enact kaupapa Māori within agencies. One participant said, 'You can still bring kaupapa Māori into public administration and still do a good job.'

Senior Māori officials play critical roles, including leadership, engagement, education, interpretation, and explanation. The role included giving clear and consistent communication of Māori positions to government and government positions to Māori. There are numerous channels for the Māori voice, each requiring a different approach:

- to provide free and frank advice to ministers 
- to discuss and debate policy issues

- to provide a Māori strategic perspective on organisational and executive matters

- to articulate the Māori narrative of the organisation

- to explain rules and regulations in a Māori context

- to present to local, national, and international audiences

- to fulfill the cultural role as speaker.

The disregard for Māori voices within public administration is keenly felt. The experiences of Māori officials ranged from feeling compelled to turn off the Māori elements of their lives, to be accepted and survive, to impressing upon others the values and virtues of kaupapa Māori.

The research emphasised that Māori leadership practices are enacted by people rather than agencies, and, aims to secure the hearts and minds of others by what feels right. Conceptually, if it feels right, it must be right. Knowing that it feels right is based on a deeper level of thinking that involves a process of understanding the context, the field of work, the goals and aspirations, the key actors and cognisance of the relational elements that are present. Experience from having spent time working in the field, provides an intrinsic level of knowing whereby one can read the cues in Māori behaviour and expression, for example, how people sit, speak, raise issues and connect with people and communities. It feels right when relationships progress to the next stage. Observing nonMāori working in this space shows how difficult and awkward it can be. Māori public servants bring this intuition and understanding to their roles. The findings convey a form of empathy, underpinned by an innate understanding of whakapapa, whānau, and kaupapa and humanistic values such as aroha and manaakitanga. The research identified that greater expression of the Māori voice provides a cognitive understanding to the heart and emotional connection of what it is to be Māori.

\section{Key Reflections}

Issues emerged from the voices of Māori experience that exemplified the philosophical conundrum for Māori officials walking in two worlds. Participants pointed out that the reality is that, first and foremost, Māori officials walk in the Māori world, and that starts 
with whānau. Māori public servants are not immune to the socio-economic factors that impact on whānau Māori as a society, such as poverty, poor health, educational underachievement, and high prison rates. Māori public servants are also leaders within their whānau, hapū, and iwi situations, and are called upon to help solve problems, from a sick grandparent or whānau members impacted by suicide to mediating between hapū or organising whānau wānanga and even national events. Māori public servants demonstrate their leadership capacities across a range of areas, and they have to do it in such a way that it does not compromise their role either as government officials or whānau members. This is not to say that non-Māori public servants do not have similar family issues that need to be addressed, but there is a difference for Māori. Māori live with societal bias. Participants were careful not to paint a negative picture but were equally aware that Māori public servants need portals for self-care and support as a leadership practice. Participants identified that the key risks are burn-out and poor decision-making under whānau stress, and therefore an inability to fully maximise their potential and progression in public-sector careers.

Māori public servants are confronted with having to comply with the expectations of agencies and managers and trade off their commitment to themselves and being Māori in the workplace. This confrontation brings about an emotion, mostly sadness; a realisation that they have drifted into the bureaucracy. Sometimes a jolt (such as a tangi) makes them realise what is most important for them. The research identified that, if Māori elements need to be present in the public sector, manaakitanga is the most important of all. One participant said 'I need to be here [at the tangi], I need to reconnect to who I truly am - be true to myself.'

Participants felt influential in their capacity to take ownership of the context within which agencies and officials operate. However, influence did not mean power. They felt that in a world where data and evidence are paramount, the dominance of statistics over stories muted the Māori perspective on and contribution to government policy and practice. Lack of Māori in senior roles, isolation of Māori in agencies, and general lack of understanding and commitment to Māori world views meant there was not the power base across the public sector to influence policy and outcomes. 
In the previous section, I presented the findings from the research undertaken at research wānanga and a series of interviews. These findings provide a broad understanding of the realities of working in the public sector, as Māori, and an appreciation for the environment in which Māori leadership practices emerge and are validated as relevant. The next stage of the research process takes a deeper look at the Māori experience and seeks to understand what it feels like, what is believed, and how Māori and Pākehā alike might make sense of Māori leadership practice. The next section outlines three cases: first, a Māori staff perspective with regards to the legacy of Puao-te-Ata-tu; secondly, the story of one Māori woman leader; and thirdly, the story of one Māori male leader.

Case Narrative: The Legacy of Puao-te-Ata-tu

A good leader has to be able to present to anybody what they believe to be right.'

(Research participant)

The initial phase of research clearly identified the deep attachment Māori public servants have to legacies of tūpuna. They continually strive to continue or advance those legacies in their modern leadership practice. In this case example, I was reminded of how the legacy of Puao-te-Ata-tu (1988) crystallises the challenge, role, and purpose of Māori public servants working in the area of welfare for Māori children. Dame Tariana Turia (2016), a staunch advocate for Puao-te-Ata-tu, stated:

we need practical solutions to tackle entrenched inequality; to create policies that make a difference. We have to act now or risk the unchecked growth of systemic bias that keeps our nation divided socially, culturally, economically. We have all the literature required to back ourselves. All we need to do is act.

During the research process, I interviewed two senior Māori officials, both Māori women, who shared their interpretation of the story of Puao-te-Ata-tu. Puaote-Ata-tu continues to be acknowledged today, and is a reminder for Māori officials in the Child, Youth and Families, Children, and Whānau Ora sector of the deep sense of grief within Māori communities concerning the care and welfare of tamariki Māori. 
As we neared the end of my interview, the two women invited me to their staff waiata session. This was significant, because they were going to sing the song 'Pūao Te Atatu'. Amazingly, the legacy of Puao-te-Ata-tu continues through this waiata 30 years after the Puao-te-Ata-tu report was commissioned. For me it sharpened the realisation that Māori officials' feel the essence of being Māori by engaging with the Māori world. Waiata was used to embed in Māori staff the significance of remembering what those who have gone before us did and to re-tell their story. The practice of waiata was a clear reminder to me of the validity of tikanga Māori practices in giving evidence of experience as any other literary form.

The case started as I attended the Māori staff waiata session, and it started with mihimihi, karakia, and whanaungatanga. Everyone introduced themselves and recited their pepeha to make connections. One of the Māori women leaders I interviewed started to tell the story. She commanded the attention of the group and conveyed the story of Puao-te-Atatu. She began:

Our people were asking for change; asking that the inequities experienced by our tamariki mokopuna whānau Māori might be addressed and so there was a huge inquiry undertaken ... after about 20 years of asking an inquiry was initiated into the way in which the Department of Social Welfare cares for whānau Māori, in particular, mokopuna Māori.

Using oratory style and tone to elevate the story and accentuate the themes of Puao-teAta-tu involving Māori communities, she continued:

It was prepared by a lovely Tuhoe man, John Rangihau. He called on kaumātua kuia whānau from all around the country and they traversed every single town in Aotearoa. They collected whakaaro, ideas, issues, worries, and concerns from the people of Aotearoa whānui about the then Department of Social Welfare.

They weren't just asking the people to talk about the problem; they were seeking solutions and what needed to change in order to see Māori people flourish in Aotearoa New Zealand.

She emphasised the point of reminding ourselves about the sense of purpose: 
This waiata was composed to always remind us that that happened, to remind us that the way to create change positively for the people is to engage those people in thinking about the change and what is required.

She continued to convey a sense that this was real for Māori people, at least in their hearts and minds, and that the challenges of 30 years ago and Puao-te-Ata-tu was a critical element of their legacy as an organisation.

So in Māori communities, Puao-te-Ata-tu continues to loom large. When I go to community hui, our people always want to have a kōrero about Puao-te-Ata-tu. It was more than a commission of inquiry. There was a report written and furnished to the Department of Social Welfare at the time. The findings are still challenging today. The first finding was we need to do something about racism in New Zealand. You know that is still hard to talk about today. They talked about that in 1986. But Puao-te-Ata-tu looked at the structural issues driving some of the things that we are still trying to solve today in our work here at the Ministry.

The Puao-te-Ata-tu narrative allows one to reflect on the work of Māori leaders of previous generations. The work of John Rangihau and others reminds us of important Māori leadership practices such as whakarongo (listening), titiro (observing), and kanohi kitea. The narrative of Puao-te-Ata-tu illuminates the struggle and fight against institutional racism, advocating for the care and proper welfare of tamariki mokopuna.

The two Māori women leaders acknowledged that the reality of kaupapa Māori such as Puao-te-Ata-tu is that the deeper meanings 'do not cognitively resonate with non-Māori' across the public sector. The narrative of Puao-te-Ata-tu, whilst powerful and appropriate within the context of the Ministry of Social Development, is confined to those, mainly Māori, who work in this area of Child, Youth and Family services. Puao-te-Ata-tu is not constituted in kāwanatanga, and its findings were disregarded and not implemented. However, as a practice, Māori continue to reference Puao-te-Ata-tu and reflect on the process, the people, and the purpose. The leadership practice that also emerges is the significance of storytelling: the capacity to reach the Māori mind in a conceptual and metaphorical form to make sense of the challenges and aspirations of Māori people. Using 
waiata in this case is a practice to place the words and their meaning into that spiritual and emotional consciousness.

\section{Case Narrative: Māori Female Leadership}

The Māori female leadership case explored the journey of one Māori woman I had the privilege of working closely with. She was a senior leader in the regional office of a large government agency, and worked at the interface of policy and regional operations within a region of high deprivation across a range of socio-economic indicators. Whilst we worked for different agencies, it was through collaborative work and partnership projects that I observed this Māori woman demonstrate leadership. She was pro-active, she was smart, and she was ambitious.

I interviewed her at her Wellington office, and immediately we connected as friends and shared mutually respectful appreciation for the work we are doing as Māori public servants. As the interview progressed it was obvious her cultural roots, her connections with her whānau, and a love for what she is doing were her key motivational factors. Her whānau is very well respected within her local community and iwi. Her late father was a kaumātua and prominent in tribal affairs, working closely with other Māori tribal leaders in the areas of fisheries, broadcasting, and Treaty claims.

As an ambitious Māori public servant, she accepted an opportunity to move to Wellington. She transitioned from senior leadership in regional operations to a general manager role, providing oversight to national operations within a large government agency. She tells me that the Chief Executive at the time took a risk on her. Her key reflection on the transition to Wellington was that it was 'really difficult'. She says she was lucky to have the support of the Chief Executive, who helped settle her down, showed her the ropes, and helped her navigate around the national office. She spent at least two years just finding her feet, getting to know who was who and who was accountable for what. There were challenges with getting to grips with how the machinery of government operated in Wellington. Understanding the political interface was critical to this. She said it was when you move away from where all your whānau support is that it becomes really daunting, and 'you've got to stand on your own two feet'. But she said, 'this is why it is important to 
develop networks when you come to Wellington'. 'What I've always kind of leaned on are our Māori staff, like our backbone.'

Her CV now makes impressive reading, as she has taken on different senior management roles, changing roles approximately every two years to build her portfolio of public sector management experience and to position herself for chief executive roles in the future. She is in a highly influential position within a large organisation that delivers government policy and services that impact upon many New Zealanders every day.

\section{Whānau Upbringing}

The most dominant element arising from the interview was the relevance and importance of whānau upbringing. The interviewee emphasised that Māori leadership practice is different to other ways of leadership, as it comes back to Māori values you are raised and brought up to understand. Māori values shaped personal formulas and approaches to deal with life and a professional career. The interviewee grew up knowing the following whakataukī. In her words she said;

'Kia ū ki te whakapono, kia aroha ki a koutou.'

'Hold fast to what you believe in, be compassionate to others.'

This whakatauki guides and grounds her Māori perspective and connects her back to her whānau base. She expressed how grateful she is for the learning she received throughout her upbringing. In one example, she referred to observing her father. She recalled, 'He'd never react in a heated situation, he always used to keep really calm and collected in terms of the way he responded. I have seen many people react in heated situations and actually it doesn't turn out well.' This recollection of her father provides further guidance to understand how Māori leadership practices occur. He reminded her of the concept of 'kia tau te rangimarie', meaning 'be settled peacefully', whereby calmness and assurance are present through the 'āhuatanga' or appearance and presence of wisdom and knowledge.

One key observation that was shared is that Māori public servants who have had a solid upbringing in te ao Māori are connected. She continued to explain that there are those 
people who for whatever reason have either been disconnected from a young age or have decided later on to disconnect themselves from their whānau or Māori world. But they do seek ways to reconnect. She recounted one story about a Māori colleague:

She separated from the wider whānau at a very young age. She had been down in Invercargill, but all the whānau are up in Kaikohe so distance was a huge thing. She demonstrated to me that although without having a strong knowledge of her culture she still had incorporated a lot of those aspects into her mahi but she had done it from a Pākehā paradigm.

She added, 'The frameworks are there for both Māori and Pākehā, but it's about how it's brought to life.'

The importance of developing personal frameworks to anchor Māori identity and connection to whakapapa and whānau was a theme that resonated throughout this storytelling process. The story emphasised the positive impact of a strong connection to whānau and being grounded in knowing who you are. Growing up, watching and listening provide a very clear sense of place. Moreover, to hold fast to what you believe in transcends any context or challenge that you may face.

\section{Vision and Purpose}

This conversation leads to the second pertinent theme that emerged: creating a strong vision for where you want to be and where you want your team to be. The interviewee said, 'It's not just a Māori thing'; however, the point that was made strongly is that you know in terms of your commitment that how you follow through is important as a leader. The conversation indicated that there is a certain way Māori public servants practice leadership. It was explained as being about getting people on board and being genuine about your engagement: 'Being Māori, you're honest and you're up front. You front people and you do that face-to-face engagement as much as you can.'

She explained that Māori leadership is natural, intrinsic, and instinctive. She said, 'It is quite hard to pinpoint!' But she added: 
You're action-oriented so if you say you are going to do something, then you follow up, which is not necessarily a Māori thing but it's something that is, you know, in terms of your commitment and your follow-through is important as a leader.

\section{Sense of Responsibility}

The story identified that Māori ways of leading emerge because, as Māori, you are connected to whānau and you feel a deep sense of responsibility. This sense of responsibility means you are here not only for yourself, but you are representing those who have gone before and those who are back in your home community: 'The nuances are the sense of responsibility.'

She said that you become really strong and aware of who you are, where you come from, and develop a 'knowing' that makes you your authentic self and, with that, courageous. She also explained that to sustain that connection you have got to get back home, keep it real, and, actually understand the impacts of some of the decisions you are making down here in Wellington: 'the importance of keeping it real, touching base back home - don't rest on your laurels down here and get too comfortable.'

Key reflections throughout the interview on the broader effect of Māori leadership practice raised concerns as to how the community comes together to have a voice in policy and public services. Critically, concerns were expressed about how Māori public servants need to grow whānau and community capacity to empower them to speak up and to raise the alarms. From a government-agency perspective, we tend to have a view that we are protecting children, educating students, rehabilitating prisoners and so forth. She worried that public servants in front-line roles were shouldering the blame for many perceived inadequacies of the public sector. She commented that the leadership practices that derive from a Māori world view are not promulgated fully and widely enough to be able to make a difference for Māori populations who are at risk and who the public sector serves.

\section{A Kete for Leadership Development}

This narrative brings to life the notion of a kete (basket) of knowledge about leadership practice and identified the critical knowledge elements and concepts. Leading with 
kindness is a core value that stems from the deep connection to whānau expressed in the Māori proverbial saying, 'Kia ū ki te whakapono kia aroha ki a koutou', 'Hold fast to what you believe in, and be compassionate to others.'

The second element is a clear sense of purpose aligned to the reasons why you started a career in the public sector. In this case narrative, a sense of purpose explained, in the interviewee's words, 'why I've stayed for so bloody long'. The key reflection is knowing your sense of place and purpose, highlighted in the quote, 'I know it's a bit of a cliché, but you do want to make a difference'.

The kete helps you to be fearless and to act with courage. The point is that if you have got that purpose and that belief, you practice culturally authentic leadership. She explained the three critical elements to the concept of 'culturally authentic leadership'. 'Culturally' refers to the connection to home - whānau, hapū, and iwi. 'Authentic' simply refers to keeping it real. 'Leadership' refers to creating opportunities. Key reflections were shared on how she keeps herself grounded in her practice: 'After every 12 weeks, I take one week off and I'll head off and go home, not only to have a break but also to connect at home and see what is happening and get the lay of the land.'

She said that, in practice, 'you've got to be able to read the audience. It is important that you understand that you bring a whole raft of experience, knowledge, and influence. You do have to be a voice. You have to push boundaries as much as you can'.

The narrative identified that there is a considerable expectation on Māori public servants because you know people involved within Māori networks. You also understand the nuances of how some things in the Māori world operate. She said, 'you are the only bloody brown face around the table' and 'I worry about dropping the ball'.

In terms of Mãori leadership development in the public sector, the interviewee said the development pathway to Māori leadership practice was about creating networks, developing your self-awareness, and continually looking at areas where you can work on your leadership development. She said that qualifications and understanding of the machinery of government, systems and processes, and how it all works had held her in 
good stead. A further reflection identified how grateful she was to have organisational leaders and mentors to support her development and transition to Wellington. She spoke highly of her mentors, and about how important it was to have a mentor or mentors to help guide you through, and added that you would need different mentors at different times in your life. Her on-the-job experiences had been incredible, she said. This went in line with having a mentor:

The organization has been bloody great to me, you know; they have given me a whole range of different development experiences. In saying that, I've given my pound of flesh, too. I've worked hard in all of those spaces.

She shared how there are some leadership elements that you have to bring yourself, such as passion, high energy, and excitement. You must have goals and be relentless about pursuing them. The major point in her leadership story is that she made some huge sacrifices coming to Wellington. 'I have career goals, and I am clear that I want to see how far I can go. But you have to "watch the ego", you have to stay balanced and make time for the whānau or you can get caught up and captured'.

The Māori female narrative emphasised the instinctive nature of Māori leadership practice. Whilst the interviewee found this hard to explain, she made the connection between how practices are informed through whānau upbringing and connection with the Māori world: for example, how she applies her whānau whakataukī in her everyday life, and how this captures the essence of her commitment to do what is right. This concept anchors one's 'rangatiratanga' at the home base, and that strength is associated with notions of authentic leadership, living by your values, and being true to yourself.

\section{Case Narrative: Māori Male Leadership}

The second case narrative is of one senior Māori official based in Wellington who is male, from Te Arawa. His position is a critical strategic management and leadership role within the New Zealand Police; he is responsible nationally for his organisation's interface with iwi Māori. He has over 30 years of experience in the public sector, and after previously holding senior roles in the Waiariki/Rotorua district has been based in Wellington for a 
long time. Our paths have crossed over the years, and more regularly whilst we have both been living in Wellington. From Ngāti Rangiwewehi, Te Arawa, he has been active in tribal Treaty settlement negotiations with the Crown and the establishment of Te Arawa's tribal commercial company.

This case acknowledges the Māori experience of the New Zealand Police has been highly unjust and discriminatory and is a difficult organisation for Māori to trust based on decades of institutional racism. This specific case example speaks of the experience of a highly influential Māori official in a senior role operating at the interface with Māori, and impacting on the lives and safety of New Zealanders every day. His role requires different forms of leadership for different circumstances, and his immediate priority is to take responsibility. He believes leaders preserve how to practice leadership by not compromising who you are. My observation is that this is a Māori leader who is proud to lead, and this resonates with his connection to his Te Arawa whakapapa. He understands the power of Māori leadership from a male perspective. His experience in tribal negotiations and high-profile national events provides an insight into his perspective of the place of the Treaty of Waitangi in building good governance and partnerships. He clearly understands the role of public-sector Māori leadership in facilitating that process. I was curious to know how that perspective of leadership had shaped his leadership practices.

The most noticeable aspect of this interview was the interviewee's practice of storytelling- to articulate and connect his experience of Māori leadership with others. For example, he reflected on the story of Hikanui Bidois, the first Māori police officer in New Zealand, and used this story to emphasise the power of Māori leadership in the plain terms of doing the right things in the right way. The interview recounted the story of Hikanui:

Hikanui Bidois was well respected in his community of Tauranga Moana. He was a strong man, a rugby player, a hunter and gatherer and a man who could communicate to locals in the community. Because of his reputation he was transferred from Tauranga to Te Whaiti and was the lone police officer through the region from Te Urewera through to Murupara. To be the lone police officer during the 1930s, when horseback was the mode of transport 
and resources were thin, meant Hikanui had to use his strength and talents to negotiate and talk with people, as opposed to using the strong arm of the law. His practice was based on the principles we understand today as community policing. His practice was to engage, as this was the only way Hikanui would survive.

He further remarked:

the story about Hikanui is reflective of that whole bloody strength and power of leadership and the power of how Māori engaged with their own people in a totally different way; so when I listen to the stories of how he interacted with our people, every interaction was a positive one ...

Recalling the Hikanui story suggested that the model of Māori leadership practice involves two key elements; first, use of whakapapa kōrero to remind others of where Māori values came from; and secondly, communication of key messages to engage in a way that resonates with Māori. This platform of understanding through narrative and engagement provides an insight into how the interviewee addressed the issues and challenges of life. He used the simple tools and practices he had at his disposal and the gifts he naturally possessed. The interviewee identified that the Hikanui story highlighted the epitome of what it is to be a public servant, that is, 'to serve people with grace and humility'. The combination of elements creates a level of influence that is the core of Māori leadership practice. Whakapapa kōrero also speaks to the themes of change and continuity and the role for the next generations of Māori leaders: to uphold those values and practices.

The second story shared in the interview involved an experience during the period of Māori occupations in the mid-1990s, when Māori asserted mana whenua rights and the determination of the protest movement meant there had to be a whole new approach to engagement. These occupations were more obvious in the Tai Tokerau and Waiariki regions. This relied heavily on the skills and experience of Māori police officers.

The protest issues were at their peak in 1996, and 36 Māori police officers were called together to map a new direction. The official approach was to take direction from local 
district councils and simply remove people. Mãori police officers took a different position. They gathered local intelligence, worked with the courts, with colleagues and negotiated with protest leaders. This changed the relationship dynamics.

During 1996, Api Mahuika, the visionary iwi leader from Ngāti Porou, challenged the New Zealand Police, and asked:

How do we exercise our leadership knowing it is going to be difficult to turn around from a traditional culture of arrest and distance from Mãori to the idea of partnership?

This would be the most difficult challenge for Māori leadership in public administration, and one that, in this particular case, Māori police officers would have to face. Api Mahuika recited the whakataukī 'E tū ki te kei o te waka kia pakia koe e ngā ngaru o te wa' ('Stand at the stern of the waka - feel the spray of the future biting at your face').

The interviewee identified that the most difficult task for Māori leadership in public administration was to change the culture of the organisation to give effect to Māori issues. The interviewee pointed out that, despite turbulent times and adversity, you needed the courage to keep going. 'It's always going to be rough, and you can become easily isolated and marginalized because of your views - not everyone will buy in. Still, it requires everyone in the waka paddling in the same direction'. He recited the whakatauki 'Ehara taku toa i te toa takitahi engari he toa takatini' ('Success it is not the work of one, but the work of many').

The interviewee reflected that, of the 36 Māori police officers, only two are left. He fondly remembered those 36 officers as path-finders, pioneers, and trailblazers for the New Zealand Police and relationships with iwi. He remarked:

We are at a tipping point whereby the organization has come to understand, if leadership is required, it is needed now more than ever. What is good for Māori is good for NZ, and, as Mãori, we are entitled as anyone to shape this. 
The interviewee's third story concerned the experience of being at the forefront of the Foreshore and Seabed hīkoi in 2004. The hīkoi was significant as it was a point at which Māori mobilised and wanted to make a clear statement to government. It was a highstakes political situation involving extensive national media coverage and public interest. The interviewee's experience involved leading the New Zealand Police team assigned to manage the foreshore and seabed hìkoi from Tai Tokerau to Parliament. At that stage, he said, the New Zealand Police did not understand or appreciate the extent Māoridom would come together as a unified force. His first decision was to choose only four staff for his team. They would be key Māori officers with high-level relationship skills.

The story was told during the interview:

Inside the protest tent, the tensions were high. Not one person trusted the Police, and the protest leaders thought I was sent to keep an eye on them and arrest. Yet despite this, by the time they got to Wellington, they were safe and secure. I recall that on the march, simple things happened. We ate together. We briefed each other. We talked. Under pressure, mainly at the point when crossing the Auckland Harbour Bridge when the whole country was watching, we negotiated with key hard-nosed leaders, such as Hone Harawira, Annette Sykes, Titewhai Harawira, and Moana Jackson. We all got over the bridge and through Auckland safely and without incident. The conversations between leaders focused on ensuring the protestors moved with dignity. The Police role was to marshal the various groups, to get people safely over the Harbour Bridge, and to keep communication lines open. The relationships built up.

The key reflection was 'It could have been a bloodbath - police were ready for battle'. His advice to the then Police Commissioner Peter Marshall was, 'If you don't allow me to control this, you'll see bloodshed, a battle'. He replied, 'You do what you need to do'.

Further reflections were shared. He asked a rhetorical question, 'Why was there confidence?' The interviewee recalled that through his leadership he had built a level of trust and confidence to be able to calm the situation. At a huge gathering after the protest, five Māori police officers were called to meet with the protest leaders at the forecourt of the Parliament buildings in Wellington. They were asked to lead the karakia for closing 
the ceremony that ended the march. This was a mark of the respect and bond that had developed during this time; it was a satisfying career highlight for the interviewee.

Lived experience working at the interface between iwi and the New Zealand Police provided the interviewee with an insight into the point of difference in Māori leadership. At best, it describes fulfilling obligations to the Treaty of Waitangi. He explained that it is necessary that we position the organisation to understand what that means.

\section{Chapter Summary}

This chapter sets out the key findings from the research. It captures insights from the voices of lived Māori experience gathered through research wānanga and interviews, and specific Māori female and Māori male perspectives through case narratives. The voices of lived experience provide rich data that demonstrate a collective perspective of Māori leadership through stories, experiences, and examples. The data-set validates the Māori experience in the public sector. It communicates critical aspects of personal concern about how Māori public servants, particularly, adapt and survive in a two-worlds context, so they may operate effectively to make a difference, and fulfil their aspirations. The data also speaks of concern on the part of Māori public servants for the body of Māori knowledge (mātauranga Māori) and how all the related elements of the Māori world are recognised and validated in the public sector.

The research identified a changing pattern showing Māori leadership in public administration having an important role in advancing mātauranga and kaupapa Māori, building organisations, and contributing to other public-sector environments in a postTreaty environment. The voices of lived experience highlighted that Māori have an epistemological basis that connects Māori leadership to a rich repository of knowledge sources. I found that this translates in practice to a unique cultural capability and specialisation in diverse Māori voice and narrative articulating a collective wisdom. It is this unique aspect that resides within those Māori people who through whakapapa and whānau upbringing express rangatiratanga. 
The next chapter considers the context of a Crown entity, and provides an in-depth look at the experience of the NZQA. The purpose of presenting a case study is to give the reader a government agency context for Māori leadership practice. The agency context situates the notion of Māori leadership in the public sector within the reality of what of occurs in practice. My personal experience and role within the NZQA also draws out elements and concepts that may be invisible to those looking in from the outside. The NZQA case study, therefore, provides a body of rich data and narratives that may either support or provide an alternative perspective to the voices of lived experience. 


\section{Chapter Five: The New Zealand Qualifications Authority}

\section{Overview}

This chapter, an organisational case study, focuses on the New Zealand Qualifications Authority (NZQA) and its experience enacting Māori leadership practices. The first section introduces the background and situates the Māori context at the NZQA within 10 years of successive Māori strategies implemented between 2007 and 2017. Data are drawn from analysis of documentation, interviews, wānanga with the NZQA Māori staff network, and the researcher's own lived experience as the Deputy Chief Executive (DCE) Māori at the NZQA. Reflecting upon my role as DCE Māori, the key challenge was to be constantly aware of the external pressures that conveyed a strong lack of trust from Māoridom, and the internal dynamics that operated beneath the surface, including an institutional bias. My vantage point, and major opportunity in this thesis, as an insider researcher, and as Māori, gave me insights and understanding that others would not have the privilege of.

Maximising this vantage point, the second section of this chapter provides an analysis of six case examples that portray 'the close-up reality and "thick description" of participants' lived experiences' (Cohen et al., 2000, p. 182). Each case example provides evidence of how the NZQA responded to Māori concerns and locates the experience within a context of leadership practice within two worlds. The third section analyses the key findings, using kaupapa Māori theory, derived from the case examples.

Interviews with four senior NZQA Māori officials conducted in 2014 and with the Chief Executive and two other senior Māori staff in 2016 were undertaken. Members of Ngā Kaitūhono (the NZQA Māori strategic advisory board) added a depth of understanding about the NZQA's journey with mātauranga Māori evidenced in conversations, meeting minutes, and publications. Strategic documents and internal materials, such as video clips, speech notes, and presentations, provided key sources of information. A NZQA Māori staff network wānanga held in April 2017 at Orongomai Marae provided an opportunity to share initial findings and, in a reciprocal manner, enable Māori staff to reflect on and digest my key narratives. Living the experience as an insider researcher enabled constant and critical observation, discussion, and personal reflection. 


\section{Section One: The NZQA: The Māori Story}

The NZQA is a Crown entity, governed by a board of rirectors, and is accountable to the Minister of Education. The NZQA has a unique role as the guardian of the New Zealand qualifications system. It ensures the system is structured to provide learners with the pathways to the skills and knowledge needed to contribute to individual wellbeing and to New Zealand's societal and economic arms. The NZQA has roles in quality assurance in the tertiary education sector and secondary school national assessment systems (NZQA, 2017, p. 6).

The NZQA, like other government entities, is a regulator that is characterised by bureaucracy, structure, hierarchy, systems, rules, and processes. The NZQA plays an important role within the machinery of government to protect the public's interest to ensure quality and value in tertiary education investments and robust and credible assessment systems to award secondary school qualifications. This responsibility affects the lives and outcomes of all learners and their families across the country.

This case study begins in 2007. This was at a time when the NZQA was coming out of a tumultuous period in its history, including a highly critical State Services Commission (2005a) report resulting in the resignation of the then Chairman and Chief Executive. There were front-page news headlines concerning the National Certificate in Education (NCEA) and Scholarship debacles and political and business debates about the role and relevance of the NZQA. The organisation had been through three chief executives in less than four years, and needed urgent stabilisation. Chief Review Officer for the Education Review Office Karen Sewell was recruited as an acting chief executive charged with improving the organisational culture. In 2006, Dr Karen Poutasi, former Director General for the Ministry of Health and a highly respected public servant, was appointed to the permanent role of chief executive, and immediately set a path for the NZQA to become 'credible and robust' and to focus on the core business of delivery of secondary school assessment (NCEA) and tertiary education quality assurance. During these years of reestablishing trust and credibility with government ministers and the education sector, 
the mantra for NZQA was 'failure is not an option'. Managers and staff were on a tight leash to deliver quality and be accountable for results and improvement.

During the same period, Māoridom was expressing concern and frustration with the NZQA's approach to Māori knowledge (mātauranga Māori). The Ko Aotearoa Tēnei report by the Waitangi Tribunal (2011) regarding the Wai 262 claim identified key concerns about the treatment of mātauranga Māori within the education system, particularly the activities of the Ministry of Education and the NZQA (Waitangi Tribunal, 2011, p. 542). Hana Murray complained about the NZQA requirement for formal qualifications to prove one can teach in areas such as weaving. She argued that tohunga-taught skills were simply not given any credit (p. 550). Te Warihi Heteraka was unhappy about the NZQA owning the unit standards for te reo, weaving, and whakairo, which he and other experts had developed over five years (p. 550). Māoridom found it worrying that NZQA accreditation processes for mātauranga Māori-based qualifications and programmes did not recognise āhuatanga Māori. Māori complained that the NZQA did not have te reo Māori capability, and that submissions in te reo Māori had to be translated for NZQA panels. The NZQA had to rely on external Māori expertise on accreditation panels (Walker, 2005).

Māori held strong views about the NZQA with regards to the lack of recognition and status of mātauranga Māori (Māori knowledge) qualifications in the New Zealand Qualifications Framework. Walker (2005) also made key statements regarding the recognition of Māori claims to education under the principles of the Treaty of Waitangi (p. 4). The underlying issue was the notion of kāwanatanga imposing dominant Western paradigms of accountability through a public management regime on what matters most for Māori, rangatiratanga, and recognition as a Treaty partner. The Waitangi Tribunal (2011) report noted that 'the issue at the heart of the matter is one of control' (p. 543). Māori agitated for the NZQA to fulfil their obligations and subscribe to the principles of the Treaty: partnership, protection, and participation.

Dr Monte Ohia was the NZQA's senior Māori manager at the time, and was highly influential in convincing Māori tertiary providers to engage with the NZQA as the development of the National Qualifications Framework and standards-based assessment was being introduced. Dr Ohia was respected immensely in Māoridom and among his 
peers. His work with iwi and whakaruruhau to establish a range of Māori qualifications and support for Māori private training establishments was instrumental in developing educational pathways for Māori. The role of whakaruruhau (the name given to Māori knowledge holders) was to assist the NZQA to develop, maintain, and promote Māori qualifications, unit standards, and associated support materials. The whakaruruhau maintains the cultural integrity of the unit standards and qualifications (NZQA, 2012c, p. 19). Ohia stated that the NZQA:

displayed courage and fortitude in convincing the executive and government to validate Māori-based qualifications as a means of abolishing the secondary school hierarchy of subjects that situated te reo and tikanga Mãori (the Māori language and culture) at or near the bottom alongside woodwork and home cookery.

(Ohia, 2006, p. 7).

Before 2007, the discord between the two world views had been obvious. The acting Chief Executive Karen Sewell and incoming Chief Executive Dr Karen Poutasi both recognised the negative Māori experience with the NZQA and the education sector more broadly. Two Hui Taumata Mātauranga, held in 2001, hosted by Ngāti Tūwharetoa, drew attention to Māori aspirations for a more effective education system. Five key platforms for Māori education advancement arose out of discussion at the hui. These included:

1. educational policies to enable Māori to be citizens of the world, to live as Māori, and to enjoy a high standard of living;

2. social and economic policies and an integrated approach;

3. Māori-Crown partnership;

4. Māori synergy; and,

5. Māori leadership; and leadership for Māori development (Durie, 2003, p. 228).

The influence of Māori academic leaders such as Mason Durie was profound in locating education within the broader socio-economic and Māori development agenda. The NZQA would need to consider its role in the context of a number of factors, including Māori demographic trends, Māori labour market participation, Māori aspirations, and the recognition of Māori knowledge. It had to reconcile the implications within its role focused on government priorities (NZQA, 2007, p. 11). 
The next section outlines the NZQA whakapapa kōrero (Māori narrative) from 2007 to 2017. Whakapapa (laying the foundation) and kōrero (stories) add significance to the journey and relationship the NZQA has had with the Māori world. This section links together a set of six case examples that depict the interventions of Māori leadership practice within a government-agency context. Each case example identifies facets and elements of Māori leadership practice that become obvious when exploring through the lenses of rangatiratanga, whanaungatanga, kaitiakitanga, and manaakitanga. The format of the cases provides a descriptive context, explains how the NZQA responded, and elaborates on what Māori leadership practices emerged. Brief summaries connect each case to another, providing a sense of journey and continuity. The case examples echo perspectives that Māori leadership is the key touchstone for Māori initiative, partnerships, and government agency relationships with Māori.

\section{Case Example 1: The Māori Strategy}

10 years ago, 2007: The Māori Reference Group, chaired by Colin Rangi, Tūwharetoa, and consisting of 10 Māori leaders with strong academic credentials and iwi connections, was commissioned to develop a Māori strategy for the NZQA. They travelled the country and felt the heat of Māori distrust and negativity in various forums. According to Wiremu Doherty, 'at the hui at Ohinemutu people like (the late) Jim Wahiao Gray really had a go at us'. Māori were 'grumpy' that the NZQA did not understand te ao Māori; that it did not have the capacity or capability to recognise mātauranga Māori in the qualifications system. There was concern Māori knowledge would be appropriated and placed on a Pākehā framework. There was a sense this would undermine the significance of iwi and hapū distinctiveness, creating a blend that would lack authenticity. There was disquiet about using Western philosophical thought and scientific methodologies to interpret Māori knowledge and Māori world views (NZQA, 2007).

As described in the background story and case example, the interface between the NZQA and Māori was contentious. The response of the acting Chief Executive Karen Sewell and appointed Chief Executive Karen Poutasi was crucial; they were prepared to take ownership of the NZQA-Māori space and be deliberate in their approach to resolve the issues. They recognised this could not be achieved alone, and called upon Māori experts 
to lead a consultation process targeting groups including schools, kura kaupapa, Māori, iwi, rūnanga, industry training organisations, polytechnics, government training organisations, private training establishments, and government agencies (NZQA, 2007, p. 38).

The Māori Reference Group engaged in a robust manner by listening (whakarongo), exploring (titiro), and communicating (kōrero) with Māori. They discussed, debated, and developed the first NZQA Māori strategy: Te Rautaki Māori 2007-2012. Sir Mason Durie played a critical role in writing the strategy. The language used in the strategy committed the NZQA to take responsibility to provide directions and pathways, and to enable the implementation of sustainable change within an environment of continuing improvement for Māori educational outcomes (NZQA, 2007, p. 3). The strategy used terms such as 'validate Māori knowledge', 'build Māori capacity', and 'recognise dual competencies' (NZQA, 2007). Durie used the term 'dual competencies' to reflect the Māori understanding that for Māori learners to be successful in the modern world they would need to be able to 'walk in two worlds'. Much of the language intimated a role for the NZQA that was outside its mandate. There were many gaps in the connections between ideas and concepts from the Māori world and the requirements and accountabilities of the NZQA.

The Māori Reference Group members were willing to put their professional and tribal reputations on the line to endorse the strategy. The strategy was highly ambitious. It aligned to wider aspirations for Māori development: for Māori 'to live as Māori', 'succeeding as Māori', and 'as citizens of the world' (Durie, 2003). The Chairperson, Colin Rangi, stated that, for the NZQA, the Māori strategy 'marks an important new beginning' (NZQA, 2007, p. 3). The Māori Reference Group anointed the strategy with a whakatauki to impress upon the NZQA the extent of the challenge:

'Ko te pae tawhiti, whāia kia tata

Ko te pae tata, whakamaua kia tīna'

'Seek out distant horizons and challenges, cherish and hold form to those you have attained' 
The point that emerged as a leadership practice is understanding Māori strategy development. Tikanga and kaupapa Māori provide concepts that make one think about issues in a different way. The significance of the second Hui Taumata Mātauranga, held in 2001, nine months after the first one, located the NZQA's Māori strategy within a whakapapa (genealogy) that created space for Māori aspirations; Māori tribal authority through the key role of Ngāti Tūwharetoa; the use of te reo Māori and whakatauki to frame the challenges; and a framework about Māori people and Māori development (Durie, 2003).

Secondly, timing is important. The development of Te Rautaki Māori 2007-2012 occurred after the 2005 Hui Taumata, where leadership and governance were a major theme (Mead et al., 2005). It was also at a time when the Te Puni Kōkiri (2006a) policy framework for 'Māori succeeding as Māori' and the 'Māori Potential Framework' was being promulgated. This leadership focus, policy stimulus, and education system drive to increase Māori student achievement in secondary and tertiary education created an opportunity for the NZQA to get on board and better understand its role in supporting Māori success.

The willingness to engage in Māori strategy was recognised by others. Ngāti Koata had praise for the NZQA, describing NZQA's 'Māori Strategic Plan' as a remarkable document that showed 'an awareness of the issues', 'a willingness and acceptance of Māori authority and control over their 'mātauranga', and an acknowledgement of 'the need for high level change to allow Māori authority, aspirations and world views with regard to their mātauranga to be exercised and recognized' (Waitangi Tribunal, 2011, p. 550). It was evident that NZQA had started its journey, but it could not do it alone. It would be better served through collective leadership, and it was this collective endeavour that was at the heart of setting a pathway for the NZQA (Ministry of Education, 2010).

\section{Case Example 2: A Māori Partnership}

In 2008, soon after the first Māori strategy was launched, the NZQA appointed a group of esteemed Māori experts to form a 'kaitiaki' group (a group of guardians). Wiremu Doherty recalled that when the Mãori experts gathered for the first meeting, they were not happy. 
They were immediately resistant. They did not see themselves as kaitiaki. They were aggrieved that they had been appointed guardians of other tribal knowledge that they did not have rangatiratanga (authority or control) over. They felt the Crown was compromising their mana. After a long discussion, they finally resolved that it was still very important to be at the table, collectively, inside government (kāwanatanga). They knew it would be beneficial to be meeting regularly with the NZQA Board and working with the executive. They saw this as the best way for iwi and Māori to influence the NZQA towards addressing Māori concerns and successfully implementing the Māori strategy. However, they would do so only on their terms, expressing their own rangatiratanga.

The decision to create a Māori partnership would have a major impact on the NZQA. The NZQA's response had to consider how to work in a way that would be consistently respectful to and open to a partnership with Māori. This could potentially disrupt how the NZQA had operated in the past, and as the proposed kaitiaki group responded tentatively, it was not exactly clear what direction this partnership would take. Fortunately, the members resolved for themselves the issue of being referred to as kaitiaki. They thought they could be influential and critical 'connectors' between the NZQA and iwi. They sought a mandate from each of their own iwi, thereby exposing themselves to iwi accountability. They called themselves 'Ngā Kaitūhono' (literally, the connectors), and by connecting the NZQA to iwi, they created a governance partnership between the NZQA and Māori (W. Doherty, personal communication, 12 June, 2012).

The strategic work involved developing terms of reference that would cement the purpose and role of Ngā Kaitūhono. The terms of reference would be written in English and te reo Māori. The final terms of reference read as follows:

'to ensure that NZQA's approach to Māori knowledge is compatible with Māori values and practises, consistent with Māori expectations, and complementary to other validation processes, including those that may be established by Mãori.'

'Ko te whāinga o Ngā Kaitūhono, he whakaū kia rite te aronga o te Mana Tohu Mātauranga o Aotearoa ki ngā uara Māori, kia hāngai pū tonu ki ngā manakotanga Māori ā, he tautoko anō hoki i ètahi atu hātepe whakamana tae atu ki èrā ka whakatūria e te Māori ā tōna wā. 
Evidence of expressions of rangatiratanga (leading and empowering others) were present. Te Rautaki Māori 2007-2012 enabled the NZQA to create a partnership and to give effect to the NZQA-Māori Treaty relationship in both a philosophical and a practical way. The establishment of Ngā Kaitūhono was the first visible indication that the NZQA was taking steps to implement the Māori strategy. Ngā Kaitūhono took the opportunity to stamp their mark with the NZQA when they conveyed the following key statement to the NZQA Board: 'NZQA does not define mātauranga Māori, iwi do' (Doherty, 2012).

The significance of this advice is the setting of clear parameters for the relationship between Māori and the NZQA and how it would influence strategy implementation. The statement was a clear reminder to the NZQA that as an agency of the Crown the NZQA did not own mātauranga Māori; nor were they the experts in mātauranga Māori: this role belonged to iwi. This statement does, however, indicate that NZQA had an important role to play, as specified within the Māori strategy, which commited the NZQA to ensure the frameworks and criteria used to quality assure mātauranga Māori in education qualifications recognised and validated mātauranga Māori.

Again, the NZQA was praised by the Wai 262 claimants for its willingness to accept Māori control over their mātauranga (Waitangi Tribunal, 2011). By 2012, Ngā Kaitūhono was firmly established and working effectively with the NZQA Board and the Strategic Management Team (SMT). Ngā Kaitūhono had to address the issue of quality assurance of mātauranga Māori in education settings, and used their experience and knowledge to support the NZQA Board to make decisions. The individuals involved brought their own tribal knowledge, perspectives, and professional experience. As a collective they engaged in a forum of debate and discussion on issues in which the NZQA's role might impact upon te ao Māori. They would ensure the NZQA was respectful to mātauranga Māori.

\section{Case Example 3: The Māori Executive}

In 2009, having successfully argued for their name to change from 'Kaitiaki' to 'Ngā Kaitūhono', the group's second key resolution was to raise the issue of the job title for the 
senior Māori role. They questioned why, if in fact the Māori role was a tier 2 role, it would have a different title (Chief Advisor Māori) to the other tier 2 roles (for example, Deputy Chief Executive)? Ngā Kaitūhono was debating its appropriateness. They argued that, if the relationship was to be a respectful one, the role should have responsibility and accountability equal to that of other deputy chief executives. The issue was raised with the Board Chair and Chief Executive, and it took less than two minutes for their decision to agree. The title was changed to Deputy Chief Executive Māori, and the job description was immediately updated and re-graded. Ngā Kāitūhono were pleasantly surprised at the speed and full acceptance of the agreement, and said this was 'big' in terms of their perception of how the relationship would unfold. Trust, confidence, and respect grew in the relationship because of this decision.

Ngā Kaitūhono had received a clear indication of the NZQA's commitment to their role and aspirations for Māori. Critically, the Deputy Chief Executive Māori is part of the organisation's SMT, with a dedicated team and access to resources. The key benefit is that the executive Māori role ensures an expression of kaupapa Māori and mātauranga Māori at the senior management level. Whilst the 'chief advisor' title might have achieved the same outcome, an executive title and role description created a mana-enhancing relationship between the NZQA and te ao Māori. Internally, the expectations increased, and the urgency for 'tangible results' were critical to justify and sustain the role and resources. The role was positioned to be responsible to the Board and Chief Executive, and Ngā Kaitūhono had created the space for executive Māori eyes and ears to be present and a Māori voice to be equal to those of others. Moreover, the level of Māori influence is magnified by the support and leadership of Ngā Kaitūhono, giving assurance that decisions and actions are grounded in a context of Māori world views. As a result, there is a strong sense of responsibility towards protecting and guarding mātauranga Māori, Māori staff, and the Chief Executive and the Board in its relationship with the Māori world.

The decision to change the role to DCE Māori created a transformation in the perception of the Māori strategy and Māori office. Staff at the NZQA observed a shift from the silo notion of the Māori office being the one-stop shop for all things Māori, mainly providing cultural support, towards a substantive and strategic role to influence and support the organisation through a distributed leadership model. Chief Executive Karen Poutasi 
directed that the only way to implement the Māori strategy was for all DCEs to take full responsibility for the implementation of the Māori strategy. The Māori strategy was organised to align with divisional business responsibilities, and DCEs are responsible for delivery.

The case is further evidence of the expression of rangatiratanga (leading and empowering others). The DCE Māori is responsible for collaboration and providing leadership, strategic advice, influence, and support to ensure the delivery of the Māori strategy and alignment with organisational goals and priorities. The new role positioned the role of Ngā Kaitūhono and the DCE Māori into the realm of being able to be both strategic and action-oriented. The role aims to:

- align Māori strategies and action plans with organisational, system, and government priorities

- engage with Māori credibly and responsibly

- identify 'windows of opportunity' that can facilitate positive change, address equity, and reduce barriers for Māori students

- provide clarity of purpose and deliver key messages in ways that are heard and understood

- integrate kaupapa and tikanga Māori practices and perspectives into organisational life.

The relationship platforms were quickly developing. However, Ngā Kaitūhono knew they had to prove themselves and set their benchmark.

\section{Case Example 4: Reframing the Conversation}

In 2009/10, Ngā Kaitūhono were starting to gain confidence in their partnership role. They recognized that the NZQA is a regulatory agency, and to intertwine dynamic elements of mātauranga Māori into a regulatory system was immediately problematic (NZQA, 2010). Ngā Kaitūhono and the NZQA took leadership action, and proposed a hui be called with Māori educationalists to 'reframe the conversation' about mātauranga Māori. At the Hui Mana Tohu Mātauranga Conference, held at Waiwhetu Marae, Professor Taiarahia Black recorded Hirini Moko-Mead, who stated the conference on mātauranga Māori was to be 'an agent of change, a catalyst for our collective advancement', and that it would 'add value to our programs, teaching and research, and set the sights for a 
validation criterion with indicators for mātauranga Māori, and measure its use by our Māori knowledge communities'. Mead continued to make the linkage between mātauranga Māori and the leadership of past leaders, making references to the portraits of past Māori leaders in the whare. He stated: 'they captured the truth and knowledge of their era. Their virtue of their collectiveness, combined approach, was based on an insight into the understanding of spiritual, philosophical and cultural parameters' (NZQA, 2009). What Hirini Mead and other speakers did was lay the platform for the NZQA to engage with mātauranga Māori. Whilst Māori who attended were cautious about the Crown's (the NZQA's) interest in mātauranga Māori and protective of their own interests, they were open to an ongoing conversation about mātauranga Māori with the NZQA.

Ngā Kaitūhono made the proposal that went to the NZQA Board to host the 2009 NZQA Hui Mana Tohu Mātauranga. Ngā Kaitūhono's idea was to 'reframe the conversation' about mātauranga Māori. The NZQA response was positive, and it committed to hold this hui. It proved to be a major turning point. Ngā Kaitūhono found a way to add value to NZQA by bringing together the NZQA and the Māori world.

The 2009 Hui Mana Tohu Mātauranga exposed the NZQA to kaupapa Māori perspectives of leadership. First, the hui was held at a prominent marae, Waiwhetu Marae, and hosted by Te Ati Awa. The hui followed Te Ati Awa tikanga, and orators welcomed manuhiri (visitors) with grace and generosity, connecting and engaging in traditional narratives. In the wharenui was a portrait of Tāwhiao, the second Māori king and leader of the WaikatoTainui tribes. The orators recalled his words of affirmation to the prophets of Parihaka, Te Whiti o Rongomai and Tohu Kākahi: 'Rapua te mea ngaro' ('Contemplate that which has been lost'). This statement referred to mātauranga Māori (Māori knowledge) that has been lost. It was clear that the purpose of this hui was one of searching - searching for answers (NZQA, 2009, p. 8).

Invited guests included Sue Suckling, Chairperson of the NZQA Board, and several board members, the Chief Executive Dr Karen Poutasi, and highly prominent Māori educationalists, experts, and practitioners. The hui expressed a commitment for change, and its significance was not lost on people. The forum discussed, debated, and challenged ideas. With the right people there, the narratives were being listened to, and taken 
seriously. The expressions of rangatiratanga were evident as leaders discussed issues kanohi ki te kanohi.

Three keynote speakers were invited to address the audience, with different ideas to inspire people towards 'identifying, constructing and elaborating' a meta-narrative, as a proposal for a new policy agenda (Schon \& Rein, 1994, p. 256).

First, composer and researcher Charles Royal spoke of harnessing the creative potential of mātauranga Māori. Royal said that modern mātauranga Māori-inspired creativity is able to bring valuable contributions to our nation's life, culture, and economy. He asked the audience questions such as 'what needs to be done to realise this creative potential?' and 'what really beats at the heart of mātauranga Māori?' (NZQA, 2009, p. 18). He used phrases for mātauranga Māori such as 'a mana-inspired way of being in the world'. He spoke of mātauranga Māori as experiences and applications of knowledge, teaching, and learning (NZQA, 2009, p. 20).

Secondly, educationalist and Māori performing arts expert Donna Grant spoke of mātauranga Māori in education: the priorities for realising the aspirations of learners and whānau (NZQA, 2009, p. 22). The narrative was about the value of mātauranga Māori, skills, and pedagogy offering pathways and accessibility to higher educational achievement for Māori learners. She provided an example of a whānau member who excelled in sports and Māori performance yet did not achieve secondary-school qualifications. The student was offered another opportunity through a Māori qualification pathway and was now fulfilling his potential (NZQA, 2009, p. 23). This story resonated with the audience, and many could recall similar stories among their own whānau.

Thirdly, Māori language experts Tāwhirimātea and Kaa Williams focused on realising dreams and desires, thoughts, hopes and aspirations, mythology, history, customs, and scholarship in mātauranga Māori through the Māori language (NZQA, 2009, p. 25). Delivered in te reo Māori, this presentation reinforced a passion and desire to increase the domains where te reo Māori can be fostered and used within whānau, communities, and marae, and in education and teacher training (NZQA, 2009, p. 32). 
In van Eeten (2007), Roe (1994) speaks of 'those stories - scenarios and arguments - that are taken by one or more parties in the controversy as underwriting and stabilizing the assumptions for policy-making in the face of the issue's uncertainty, complexity, or polarization' (p. 251). This place of Waiwhetu Marae, the space of mātauranga Māori, the clarity of thought and key messages of hui participants, inspired the gathering. The reframing of the conversation about mātauranga Māori created hope and aspiration. The question of 'what is quality mātauranga Māori?' was answered as 'a dynamic and evolving range of knowledge areas; not limited to Te Ao Tawhito (the old world) and includes everything in Te Ao Māori (the Māori world)' (NZQA, 2012b, p. 99). Recognising and validating mātauranga Māori was now not seen as a problem, but an opportunity for the NZQA and Māori to work together. Black summarised that the hui brought together the different strands of mātauranga Māori, especially aspirations regarding the social, economic, and cultural opportunities relevant to Māori learners (NZQA, 2009).

The 2009 Hui Mana Tohu Mātauranga created the platform, relationships, and ideas to re-focus implementation of the NZQA Māori strategy. Expressions of manaakitanga were evident as people gathered and were hosted by Te Ati Awa iwi and the people of Waiwhetu. The outcomes from the Hui Mana Tohu Mātauranga would underpin strategies and actions that would follow. The Book of Conference Proceedings became a document that would lay the foundations for the NZQA to engage with mātauranga Māori. Professor Taiarahia Black wrote in the Book of Proceedings, 'It's about the ability to reframe the conversation with intellectual capital, compatibility with traditional and contemporary knowledge, with energy and leadership' (NZQA, 2009). The NZQA's relationship with mātauranga Māori was beginning to emerge and, specifically, through events, stories, and people, important connections were starting to develop and a narrative about the NZQA relationship with Māori was building. NZQA staff were growing in confidence about stepping into Māori spaces, not as experts, but as facilitators and navigators traversing a new space and leading people into new undefined territory.

Through the Māori strategy, the NZQA was opening the door and inviting mātauranga Māori into its organisational life. Reframing the conversation created the start of a new relationship between Māori and the NZQA - whereby developing a framework based on 
kaupapa Māori principles would be essential to the sustainability of the NZQA-Māori relationship, and advancement of mātauranga Māori. But it was not all plain sailing.

\section{Case Example 5: Kaupapa and Tikanga Māori}

In 2012, the NZQA faced a serious challenge by Māori as the Targeted Review of Qualifications (TRoQ) policy was implemented. The aim of the TRoQ policy was to develop a unified New Zealand Qualifications Framework. This required a programme of mandatory periodic reviews of qualifications to determine whether they were still fit for purpose. The aim was to reduce the proliferation and duplication of qualifications and provide clearer pathways for students and employers (NZQA, 2017). Māori had two problems with this policy. First, they associated the word 'unified' with 'assimilation' and were annoyed that iwi knowledge would be exposed in the public domain. The concept that a unified New Zealand Qualifications Framework, managed and controlled by the Crown, would allow others access to the intellectual property rights of Māori was inconceivable to Māori. Moreover, Māori did not want to see qualifications 'generalised' to the extent that they were accessible by all. Secondly, Māori associated the word 'reduce' with 'confiscation'. They considered knowledge confiscation was akin to land confiscation. This notion would be unbearable in a modern New Zealand. Māori believed that to shift the ownership and control of iwi-based qualifications, and therefore mātauranga Māori, to the NZQA, to reduce qualifications, would be an act of confiscation. Māori objected to the loss of rangatiratanga and ownership of the design and offering of iwi qualifications and their associated programmes. Māori were seeking an exemption from the policy and process until such matters were resolved. This issue needed to be resolved, and the approach to develop a kaupapa Māori framework to recognise and validate iwi distinctiveness offered a potential solution. This experience would take the NZQA into a space of conflict with no easy resolution.

With the support of Ngā Kaitūhono, the NZQA SMT and Board approved the exemption from the policy on the proviso that the issue be resolved within a specific timeframe. The NZQA had to remind the people concerned that the NZQA had decision rights but the NZQA was open to work on options to resolve the matter. The response to Māori concern needed to be underpinned by mātauranga Māori perspectives for any attempts to work in this space to be regarded by Māori as genuine and sincere. The aim was to create space for Māori distinctiveness, knowledge, language, and cultural pedagogy in the 
qualifications framework and to ensure the integrity of both worlds. The leadership challenge was to negotiate this space in a way that one world would not compromise the other (NZQA, 2012b, p. 100). Key principles emerged from this process that were based on mutual trust and respect. The principles included:

- maintaining integrity

- open relationships, co-discovery, and no surprises

- focus on outcomes that mattered

- 'quality' and the needs and aspirations of people (p. 102).

Although the foundations for working through the issues had been agreed, the negotiations relating to mātauranga Māori and quality assurance languished in a context of historical mistrust and injustice. The practice of meeting face to face (kanohi ki te kanohi) with Māori education sector representatives was at times threatening and uncomfortable. Values would be tested as attacks on the Crown, and the professional and personal integrity of staff working for the Crown were fierce. One NZQA participant commented: 'When meeting face to face with Māori, some of the behavior was antagonistic and tough. Staff had to find ways to overcome it'.

The position that NZQA accepted wholeheartedly was that NZQA does not attempt to define or own mātauranga Māori - this was an explicit acknowledgement that this body of knowledge remains within the care and guardianship of whānau, hapū, and iwi, and hapori Māori (Māori communities) (NZQA, 2012b, p. 99). The NZQA knew it could not assume or pretend to be the experts on mātauranga Māori. The role for the NZQA in carrying out its quality assurance function is to understand and acknowledge the aspirational nature of these endeavours and balance this with the need to recognise the integrity, validity, and quality of mātauranga Māori courses, qualifications, and providers (NZQA, 2012b, p. 99).

After extensive engagement hui and consultation, models of mātauranga Māori quality assurance were emerging. In partnership with Māori stakeholders, conversations and debate about kaupapa Māori definitions of kaupapa (principles), whāinga (goals), and pātai (evaluative questions) continued. Simultaneously, in the Western world of 
education evaluation, concepts such as outcomes, quality, and value were being discussed. At the interface between two world views, negotiations about equity and the legitimacy of knowledge created a space for mātauranga Māori and evaluative quality assurance to be debated.

The philosophical and intellectual debate was intense for the NZQA and Māori. At the core of the tension within education quality assurance is the issue that is felt as a bias that judges kaupapa Māori and mātauranga Māori to be not as valid, robust, or rigorous as Western forms of evaluation or quality assurance. Those who appreciate mātauranga Māori realise the expectation of quality and value to be much higher and far more rigorous than what is required from a Western perspective. However, it is a difficult area to traverse when there is a lack of understanding or willingness by others to engage in an open manner. The process became reliant upon key individuals on both sides of the fence. The nature of the dialogue was sophisticated and thoughtful. Expressions of kaupapa and tikanga were critical elements in negotiations. The NZQA had to demonstrate that it knew what it was talking about with regards to mātauranga Māori. One research participant commented that the NZQA had to 'walk the talk':

Our team worked with an external advisory group to develop tools and processes for evaluating mātauranga Māori qualifications. In essence, the issue wasn't so much about designing appropriate evaluative tools as it was about securing mutual trust. We have to be patient and be committed. Once you start the journey, you can't walk away.

The co-creation and development of kaupapa Māori frameworks emerged as a practice to enunciate the dynamics of two systems of thought and to bring them together in such a way that one system of thought would not dominate the other - that they could sit side by side on equal terms (NZQA, 2012b). The final product, co-created by Māori and the NZQA, is Te Hono o te Kahurangi. Te Hono o te Kahurangi resolved the problem identified in the first Māori strategy, to recognise and validate Māori knowledge in quality assurance systems (NZQA, 2007). Te Hono o Te Kahurangi is metaphorically referred to as a whare ako that is utilised for advancing, critiquing, and evaluating Māori knowledge in the context of the NZQA's role in tertiary education. Te Hono o Te Kahurangi is a unique framework with tools to initiate evaluative inquiry (NZQA, 2017b). What this means for 
tertiary education institutions is that the NZQA has an in-built capacity and capability to evaluate and assess qualifications listed on the New Zealand Qualifications Framework, programmes of study leading to those qualifications, and evaluation and review of organisations' educational performance and capability in self-assessment to be undertaken from a kaupapa Māori perspective. Six dynamic and inter-connected kaupapa are at the heart of this whare ako framework. The major difference in evaluation between non-Māori and Māori is the way evaluators frame and undertake their inquiry; in the case of Te Hono o te Kahurangi, by asking open-ended questions relating to how education providers respond to and express a specific kaupapa.

The kaupapa are:

- rangatiratanga

- whanaungatanga

- manaakitanga

- pūkengatanga (skills and expertise)

- kaitiakitanga

- te reo Māori.

People could see right through and we finally realized the only way to engage with the Māori world was to engage through the Māori world, through mātauranga and kaupapa Māori.

(Research participant)

Before the naming of the kaupapa Māori framework, the programme of work was referred to as Mātauranga Māori Evaluative Quality Assurance. I recall attending an advisory group meeting. We were sitting at Te Kōhanga Reo National Trust, and the concept of a whare model was being discussed. Pakake Winiata, from Ngāti Raukawa and Ngāti Whakaue, arose to suggest the name Te Hono o te Kahurangi (the jewel in the crown). He explained how Te Hono o te Kahurangi reminded him of the famous Māori love story of Hinemoa and Tutanekai. Guided by the sound of the pūtorino (nose flute), Hinemoa swam from the shores of Lake Rotorua to be with Tutanekai on Mokoia Island. The descendants of Hinemoa and Tutanekai have this wonderful love story that provides a strong sense of belonging to Rotorua and to Te Arawa. In much the same way as 
Hinemoa and Tutanekai united the Arawa tribes, the opportunity for the new whare model, as a place and space for mātauranga Māori, was, indeed, a jewel in the crown, hence Te Hono o te Kahurangi.

In this respect, tikanga practice, as a leadership practice, was critical to developing kaupapa Māori models. According to Hirini Mead (2003), tikanga Māori in its simplest form refers to living by Māori values. The tikanga practices that surrounded this process helped to develop a mutual respect and sharing knowledge to contribute to discussions about interpretations of the space between Māori knowledge and Western knowledge. The NZQA were fortunate to have Syd King, a Pākehā and an intelligent evaluation expert who could bring both high levels of debate and empathy into the negotiation process, and Tui Marsh, a curious and forthright Māori official who would seek clarification on every issue and demand that both Syd and the external mātauranga Māori working group were truthful and consistent in their assessment and management of issues. Through sheer hard work and openness to listening to Māori views, Syd and Tui managed to find a common ground with the mātauranga Māori working group between a Pākehā world view and a Māori world view. The negotiations took place in a context in which Māori felt that tikanga was respected. This practice of following appropriate tikanga created a positive environment. Genuine and mutual respectful relationships developed, and this helped to create mutual understanding and build capabilities. The essential elements within this tikanga practice were the people involved.

For the NZQA, mātauranga Māori provided the source of knowledge to underpin Māori leadership practice. Operating in this space required intense attention to the forces operating beneath the surface that undermine or under-value kaupapa Māori perspectives. Moreover, there are leadership practices that are critical to enable Māori officials to withstand the burden of representing the Crown and defending Crown positions. In one situation, the NZQA and its review panel had to enter an education establishment to undertake a week-long review process. The week started with a formal pōwhiri. The tikanga practice of whaikōrero (Māori oratory) demonstrated how tikanga practice can build a common and respectful understanding of perspectives to create space to engage. 
We arrived at the pōwhiri. There was tension. Then when our speaker got up to whaikōrero you could see their ears prick up, their bodies turned, they listened, and then they smiled. Our speaker acknowledged their history, their whakapapa, their development and aspirations. It showed we were 'seeing through their eyes'. They responded well and the air was cleared. There was a mutual understanding, and we were then able to engage with them and do our job. The whaikōrero was crucial. That was Mãori leadership in practice.

(Research participant)

This deeper insight emerges by getting to an intimate place of knowing what the Māori experience looks and feels like from the Māori perspective and from their interpretation of the relationship they have with the Crown. It is from this depth of understanding that the nature of the relationship becomes much more positive and moves towards a level of trust. The cognisance of kaupapa and tikanga Māori at the NZQA was beginning to take hold.

\section{Case Example 6: Manaakitanga}

Whaea Liz Hunkin recalls the story of when she and the late Katerina Mataira visited Chief Exectuive Dr Karen Poutasi at the NZQA to discuss Te Ataarangi business. After the mihimihi and karakia, Karen got up to offer and pour a cup of tea for them. Whaea Liz was absolutely amazed at the actions of the Chief Executive. She said, 'it wasn't just the fact that I was offered a cup of tea; it was the fact that it was the Chief Executive who offered and poured the tea. Not the staff, but the Chief Executive. Now to me, that is leadership. It demonstrated to me that Karen understands what manaakitanga is about.' From a tikanga perspective the offering of food and drink nullifies the state of tapu (sacredness) on the participants and brings them into a state of noa (where tapu is nullified). This tikanga perspective expresses manaakitanga and creates and builds long-lasting relationships. Whaea Liz admires and appreciates the NZQA for this experience. It creates a culture within an organisation that respects people, and it makes Māori staff (as followers) feel good about the organisation because of how the organisation treats manuhiri. This one small action demonstrated Māori leadership practice and enhanced the organisation's reputation.

It's an organization with a human face, a human culture, the tone is set from the top that this is a whānau and its people first. 
The capacity of the NZQA to respond and to engage meaningfully with Māori is based on a gradual process, incorporating the NZQA's values and embedding an understanding of a Māori world view (NZQA, 2012a, p. 14). The process started soon after the 2009-2010 NZQA Leadership Development Programme for NZQA managers. This programme aimed to help senior and middle managers reflect upon their roles as leaders at the NZQA. It left Steve, the communications manager, with a strong urge to begin a process to develop NZQA values. He took this on as part of his action plan. Steve engaged other staff and set up workshops and activities. Others joined in and helped. They adopted the concept of weaving flax as a way to incorporate organisational and Māori concepts. The values matrix used Māori terms and descriptions, and these were tested with other staff. This process created Ngā Mātāpono - a core set of values that now forms part of the strategic backbone for the NZQA. 


\section{NGĀ MĀTĀPONO}

(O) D $\triangle(0)$

\section{RESPECT}

We value and consider the professional views, culture and beliefs, feelings, needs and efforts of others.

We give equal consideration to others. We say what we mean, listen respectfully and think and act constructively.

RANGATIRATANGA

EMPOWERING AND

LEADING OTHERS

WHAKAPONO

OPEN AND

TRANSPARENT

MANAAKITANGA CARING FOR AND

VALUING OTHERS

KAITIAKITANGA GUARDIANSHIP

We ensure New Zealand We ensure New Zealand
qualifications are credible and robust nationally and internationally.

We strive to establish, maintain and improve quality services and high standards of responsiveness.

-We actively build staff and the organisational capability.

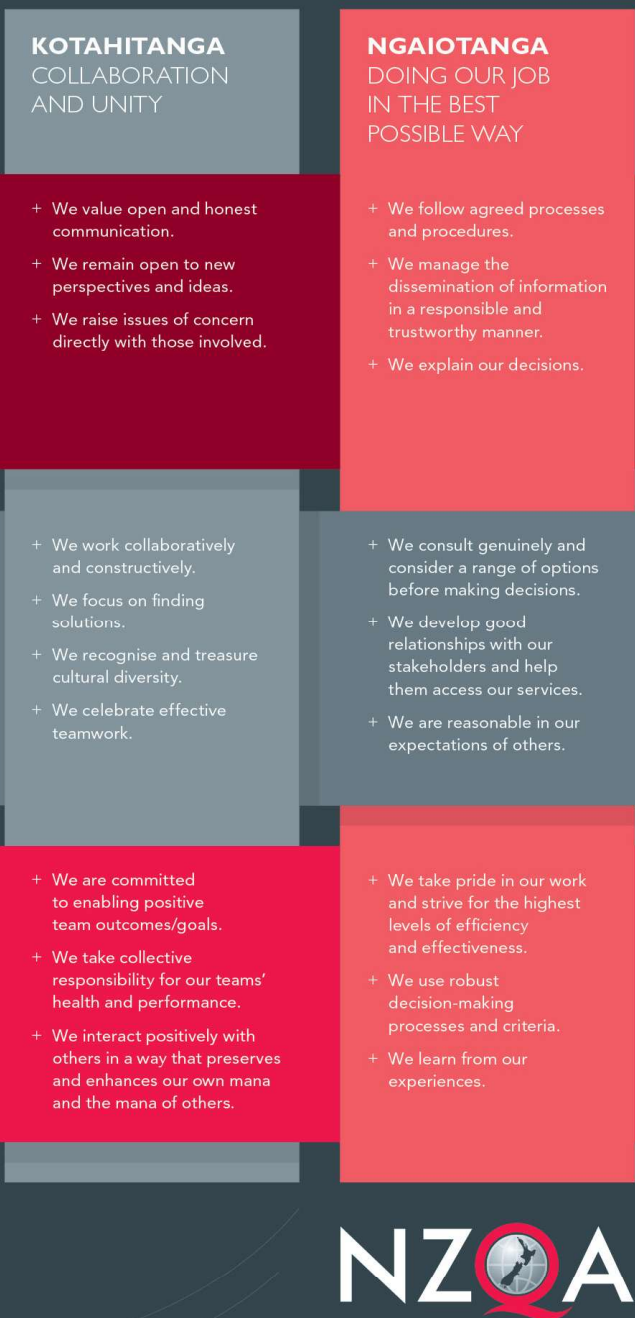

NEW ZEALAND OUAUIFCATONS AUTHORITY
MANA TOHU MATAURANGA O AOTEAROA KIA NOHO TAKATU KI TÓ ÁMUA AO!

Figure 2: A diagram showing NZQA's Ngā Mātāpono (NZQA values) 
NZQA research participants commented that in the early days Ngā Mātāpono were viewed as something that was nice to have at the NZQA. Staff did not really engage with them, and the general view was that they would disappear. Over time, Ngā Mātapono started to emerge as a platform for engaging with Māori. Ngā Mātāpono would become a normalised element for the organisation.

The NZQA Māori strategy focused on building cultural competencies among staff, te reo and tikanga Māori awareness and the capacity to respond to Māori needs and issues in a general sense.

If we're talking Māori stakeholders, NZQA is demonstrable in its commitment to Māori - te reo, tikanga - it's something that hits you when you come here.

(Research Participant)

Leaders now refer to NZQA values, and regularly use words such as waka and whānau to describe the NZQA. It is not unusual to hear staff talk about NZQA values and what they mean. NZQA staff engaged in tikanga Māori programmes and started to learn more, developing a growing appreciation of the relevance and importance of Ngā Mātāpono as a central guiding philosophy and practice.

'Currently, the relationship with NZQA is the best I have known in 10 years.' 'NZQA is now more responsive to Māori. NZQA people are different now than they used to be, so the relationship has changed.'

'There is now greater transparency and respect.'

(NZQA, 2010, pp. 32-34)

There is also an increasing appreciation ... that important values when engaging Mãori are being recognised. Mana and rangatiratanga are being valued, and communities' needs and preferences are being acted on demonstrating NZQA can effectively engage with Māori. 
This case example identifies the importance of role-modelling values such as manaakitanga as a leadership practice. Interviews with staff identified that it makes a significant impact on colleagues and building relationships with external clients. Participants confirmed that Māori engagement requires an approach that not only is respectful to tikanga and kaupapa Māori, but is also genuine. Genuineness in this context is achieved through manaakitanga - caring for people.

A major factor for Māori staff is the NZQA's working environment being conducive to kaupapa Māori. The point was made that it is not like this in every government agency. One participant talked of how powerful it is to see leaders speaking te reo Māori, reciting pepeha, and making connections with Māori staff. One participant stated, 'Seeing senior leaders try, it helps staff feel safe and be open to engaging'. 'The role modelling speaks volumes of NZQA willingness to engage at all levels.' Other participants commented, 'leadership is grown, role-modelled and everybody is made accountable' and 'Now my whole team promote and practice our tikanga and are trying to normalize it.'

Participants applauded the commitment of the NZQA to incorporate 'Engaging with Māori' as a core competency for all staff of the NZQA. One participant commented, 'Having an "engaging with Māori" core competency ... and it's in everyone's job description, that is big.'

The competency framework creates opportunities for staff, at whatever level, to develop skills and practices to engage with Māori. Established and implemented at the NZQA in 2012, the framework seeks to ensure that the NZQA always engages meaningfully with Māori, underpinned by Ngā Mātāpono. The Engaging with Māori competency aligns with seven other competencies of the NZQA People Plan, and provides guidance for managers recruiting and developing staff. Applying Māori concepts based on a 'growing a plant' metaphor, the Engaging with Māori competency is measured by:

- te kākano - new potential beginnings

- tipuranga - growing/nurturing

- manaakitanga - empowering/encouraging

- pūawaitanga - realisation/self-actualisation. 
This case example locates Māori staff at the heart of Māori leadership practice as they understand the importance of manaakitanga. One participant noted, The Māori element is manaakitanga.'

This section provided six case examples of how a government agency enacted Māori leadership, and presented the cases as critical interventions that occurred over a period of 10 years. The NZQA Māori strategy that was launched in 2007 marked a new beginning for the NZQA and a phase of organisational change and improved relationships with Māori. There was no magic wand or silver bullet, but when considering the totality of the cases, a narrative can be drawn that shows the importance of continuity and collective leadership.

\section{Section Two: Reflections}

At this stage of the study, I assume my vantage point to reflect upon the NZQA case study. I reflect upon how Māori leadership practice is enacted within an organisational environment. As I was deeply involved in each of the cases, I reflect upon how the practice orientation of leadership is a far more honest and compelling locus for Māori leadership, as distinct from leadership as heroic and overly concerned with the skills and attributes of the leader. The five reflections that follow point to why Māori leadership-as-practice matters, and what government agencies might consider within their own situations and context.

\section{The Chief Executive Sets the Scene}

The chief executive sets the scene by his or her actions. Agency positioning is recalibrated by developing a rangatira (chiefly) relationship between Māori and the agency. This relationship balances Crown responsibilities with the aspirations of Māori, giving effect to the principles of Te Tiriti o Waitangi, and is enacted through the expression of manaakitanga. Within the NZQA, the absolute willingness of the Chief Executive to take advice from Ngā Kaitūhono and to re-position the DCE Māori role to the equal status of other deputy chief executives was a crucial action that had an immediate effect on the 
nature of the NZQA-Māori partnership. Moreover, the implementation of successive Māori strategies indicated that the NZQA's model was working. The Chief Executive used a leadership model, endorsed by the NZQA Board, that distributed accountability for Māori outcomes across the agency. It was not the DCE Māori's responsibility alone; everyone was accountable.

The Chief Executive sets the scene from a practical perspective by her actions. Weekly SMT meetings start at 8.30am every Monday morning. The SMT meets in the Chief Executive's office, and the Chief Executive opens the meeting by reciting her pepeha and mihi, in te reo Māori. The mihi begins with the NZQA whakataukī:

Te manu ka kai i te miro nōnā te ngāhere

Te manu ka kai i te mātauranga nōnā te ao The bird that partakes of the berry his or hers is the forest The bird that partakes of knowledge his or hers is the world

(NZQA, 2014a)

In her mihi, she outlines the NZQA Māori strategy (Te Rautaki Māori) and the five work streams, including the responsibility of each DCE to the Māori strategy. She then concludes with the whakataukī:

Nōku te rourou, nōu te rourou ka ora ai te iwi. With my contribution and your contribution, the people will prosper.

This practice might seem simplistic and even tokenistic to some. Yet despite those perceptions it has provided a way for the Chief Executive and other leaders to demonstrate commitment to learning te reo Māori. Managers and staff become curious and ask questions about te reo Māori and tikanga Māori. They copy the practice, and it cascades to other managers and teams.

This leadership practice impresses upon the senior leaders the need to speak te reo Māori, and whilst this is nerve-wracking for some, it is conducted in a safe environment where people are not scolded for making mistakes. Rather, they learn and embrace the 
opportunity. Perhaps more importantly, it prepares them for the monthly whakatau (informal Māori welcome) to welcome new staff - a further step in te reo Māori learning for the SMT.

Two years ago, I went to a whakatau to welcome new staff to NZQA. I had to speak English, when my colleagues spoke in Māori, because I didn't have any words to introduce myself; I felt like I was letting my team down. And so I stood up and committed to everyone there that things were going to change - and that's when my learning of te reo Māori began.

(NZQA, 2012c, p. 16)

The elements of whakataukī, ngā mātapono (values), whakatau (welcome), and te reo Māori me ōna tikanga (Māori language and customs) create an environment that feels Māori and feels like leadership. The Chief Executive sets the scene by role-modelling and creating the expectation for other leaders to follow. The Chief Executive sets the tone for kaupapa Māori within the agency, and the extent to which the pursuit of better outcomes for Māori impacts the entire organisation. The NZQA example shows progress can be made when Māori strategies and Māori practices are 'embedded in our culture, our thinking, our planning and our day-to-day processes' (NZQA, 2014a, p.2).

This practice orientation emphasises the importance of leadership and the absolute commitment of the Chief Executive. The Chief Executive shows leadership not only by leading the process on Monday morning, but also by working harder than others to learn pepeha, mihi, and whakataukī and performing those elements well. Staff members are amazed and inspired by the Chief Executive's performance with te reo Māori at whakatau. It is not perfect, but it is well prepared, and articulated with confidence and purpose. The notion of leadership from the top - leadership by example, role-modelling, and supporting others - is a key feature of Māori leadership practice; in this case, by nonMāori. This practice signals that Māori matters to the NZQA, and it is our responsibility to do our best. 
The expression of manaakitanga creates a leadership environment at the NZQA that is about 'the way we do things around here'. The key aspect of the NZQA case example is that the Māori context supports staff to grow and develop and be confident engaging with Māori. Māori leadership practices emerge as an outcome of the socialisation, engagement, education, and contribution of leaders and staff who actively work on the leadership environment - a place where Māori values, te reo Māori and tikanga, and outcomes for learners are valued.

At monthly whakatau, each member of the SMT stands up to address a full room of staff. They begin with reciting pepeha and mihi. In their welcome to new staff, SMT members refer to expressions of Ngā Mātāpono. They take the opportunity to explain the impact and relevance of Ngā Mātapono to work and life at the NZQA. Managers and staff attend the whakatau to support the 'newbies', and there is a real sense of whānau and the notion that new staff have joined the NZQA waka. One-on-one support is available for management and staff to help them learning the language. For managers who introduce new staff and the new staff themselves, a full briefing on whakatau procedures and te reo Māori preparation is provided.

The practice orientation is evident by the NZQA's commitment to welcome new staff with a whakatau; Te Wiki o te Reo Māori celebrations; participation at the annual inter-agency kapa haka event, Te Konohete; annual wānanga for Māori staff; the way the NZQA applies kaupapa Māori to evaluate qualifications, programmes, and tertiary education organisations; and how the NZQA engages with whānau, Māori students, and the education sector. All the elements are related. When new staff are welcomed to the NZQA, they learn from the outset what the NZQA values - our staff and learners throughout the country. Māori leadership practices, in the NZQA case, have shown a positive and impactful contribution to how the NZQA delivers its services and maintains its relationships with Māori.

Research participants were willing and keen to tell their stories and to share their experiences. Whilst they talked with pride and satisfaction, there was also trepidation 
and a slight fear of the NZQA losing the gains made when key people leave. They were also very protective of gains for Māori that have been made and averse to anything that would take kaupapa Māori backwards. The challenge for the NZQA is continuity of practice, and to embed expressions of Māori values and practice over long periods so the humanistic elements of the NZQA, such as manaakitanga, endure.

\section{We are Still Credible and Robust}

The case study identified that agencies lose nothing by adopting kaupapa Māori, mātauranga Māori, tikanga Māori, and te reo Māori into their organisational life. The practice of inviting Māori elements into an agency has been shown to improve the vibrancy and responsiveness of the agency and improve relationships with Māori. In the NZQA's case, 'credible and robust' is the core tenet of New Zealand's qualifications systems, yet there is no evidence to suggest that the system is less credible, or less robust because of NZQA's approach to validating mātauranga Māori. In fact, the introduction of Te Hono o te Kahurangi enhances the quality assurance system by enabling mātauranga Māori to be recognised on its merits. The major benefit is that the reputation, trust, and confidence between the agency and Māori builds over time.

From an insider perspective, the case provides evidence that creating a culture and environment that embraces mātauranga and kaupapa Māori is positive for the agency. It is not dependent upon one leader, but involves a team approach, including the board and executive team, to sustain the credibility of that environment. Execution of practices, initiatives, and events must be supported and inclusive of all. Māori elements such as manaakitanga must be present, consistently.

\section{Māori Staff Leadership}

'What secures the trust is having the right people. Good people work together,' one participant commented.

Māori leadership in government agencies really matters for Māori staff. The NZQA case example shows the type of pressure Māori officials sometimes find themselves in. They 
do get caught between two worlds, and need support, role models, and an environment where they can express themselves as Māori.

Feedback from the NZQA Māori staff network wānanga provided insights into how it feels for Māori working in an agency. Māori staff concurred with themes that are relevant to the context of managing the two-worlds interface, such as the critical positioning of mātauranga Māori, balancing tikanga in organisational environments, and respecting the whakapapa of the organisation. They recognised that the strengths of Māori leadership sometimes get lost in hierarchical structures established by the agency. They commented that you have to 'be prepared to challenge the status quo. You have to pick the right battles so you get a return on the energy you have spent'. As Māori, 'you have to have courage to stand for what you believe in'.

Māori staff comments also reflected that, irrespective of roles and positions, we are all leaders. 'Everyday, we have to make decisions on what to do.' We are 'always looking at the bigger picture' and always have 'empathy and understanding'. Māori staff within the organisation step into the leadership frame and interact with non-Māori managers, colleagues, clients, and stakeholders. Māori staff assume certain positions, and negotiate to ensure kaupapa and tikanga are properly addressed.

Māori staff are courageous in leadership settings, but this becomes easier when they are secure in their identity and feel culturally safe in the agency environment. They commented that this is possible when the organisational values recognise tikanga Māori. It makes it easier to follow behind the organisational leaders. One participant said:

'as kaimahi, as Māori public servants, there is absolutely a leadership role for us no matter what our formal position is in the organization. Mainly because there are so few of us, it is us our colleagues and managers look to. Whether we like it or not we must step up. It also means we have to be twice as good. We have to be good at our jobs and we have to be pono (true) to ourselves and do it well. We are reminded about how people would like to work with you. They engage you as a person mindful that working with you is about your quality of work that they respect. As Māori we need to understand this and express manaakitanga. That is leadership. 
The cultural strength of the Māori staff network and organisational ownership of the Māori strategy had a major effect on the organisational positioning in relation to Māori. In the NZQA document (2010) on engaging effectively with Māori, participants reflected upon the characteristics of leadership within the NZQA 10 years ago and compared it with the current leadership. They said:

'Back then, there was no overarching vision, people didn't talk to others and generally people operated in silos. Leaders generated it. People did their best under those circumstances.'

'There is now a human face, a human culture, visibility and accessibility to leaders.'

Participants noted the impact Māori staff had on how senior leaders thought about how they behaved in Māori contexts. The way the relationship with mātauranga Māori unfolded at the NZQA was having an impact on other aspects of the NZQA. The organisation was changing, and leaders and staff were becoming more comfortable with the notion that the NZQA was an organisation that valued kaupapa Māori, mātauranga Māori, te reo, and tikanga Māori. The NZQA had developed the NZQA's values (Ngā Mātāpono) and an Engaging with Māori competency framework to underpin and guide staff's efforts in the relationship. The practice of educating the workforce was in its infancy, but there were changing behaviours and critical practices, such as whakatau for new staff, were having an influence.

My observations of Māori public servants, particularly Māori staff at the NZQA, are that Māori public servants are striving to achieve their own goals and aspirations, to support their whānau, and to pave the way for other Māori. They are interested in how their role in the organisation contributes to the needs and aspirations of Māori. There is a mindset of achievement and excellence, and this translates to the commitment to their role at the NZQA to deliver quality outcomes for learners. There is a positive perception as Māori staff have a good Māori spirit; they are competent and qualified in their roles. Māori staff express their commitment and passion for their cultural identity, including by speaking te reo Māori and expressing whanaungatanga. The working environment is conducive to 
kaupapa Māori. At the NZQA Māori staff can be Māori. They do not have to wait until the weekend to be Māori.

\section{Sharing our Stories}

Of course, the voyage ahead will not be without its challenges. We may well face storms, towering waves, and navigational challenges!

Without the proper guidance and expertise, this voyage will founder on the many hidden reefs, rocks, and whirlpools.

(Suckling, 2009)

The NZQA journey with mātauranga Māori was unanticipated. It was a journey similar to a waka traversing new waters heading into the unknown. The NZQA navigated these waters and incorporated various elements of the Māori world into the life of the NZQA through the implementation of its Māori strategy. The NZQA experience is consistent with key findings from the voices of lived experience outlined in this chapter. Relationships, connectedness, and continuity are consistent themes that have emerged throughout the story thus far.

The case study highlights the importance of Māori narratives to guide and support an agency. By 2017, the NZQA had established whakapapa kōrero as a platform and logic framework to enact Māori leadership. The framework would empower the agency to move into a future world confident about its place and relevance to Māori. The case identified that the enactment of Māori leadership practice is not one specific element that meets a measurable threshold. It is a total commitment of sustained strategic and actionoriented work, and consistent effort to improve the way the agency engages with Māori and responds to their needs. It is collective, as Māori leadership practices emerge in multiple ways by many people interacting and connecting theory and practice.

The crucial part of getting the words of Te Rautaki Māori off the pages and turning them into action to achieve results for the strategy.

(Suckling, 2009) 
The NZQA case identified that when agencies open their hearts and minds to accept and engage with mātauranga Māori (and te ao Māori), their journey with understanding elements of Māori leadership begins. The second step is to take action by engaging in conversations about Māori values and aspirations, and caring about them.

Sharing stories through hui, wānanga, conferences, and publications emerged from this case study as a form of Māori leadership practice. These stories demonstrate respect for the integrity and importance of mātauranga Māori and Treaty-based relationships. They demonstrate Māori strategic, collective, and relational rationale. The case identified that Māori working in government agencies are the critical connectors who conceptualise and activate opportunities for mātauranga Māori knowledge and stories to be shared, highlighting the distinctive contribution of kaupapa Māori to leadership within government agencies.

\section{Chapter Summary}

This chapter reflected on the NZQA experience with mātauranga Māori and engaging with Māori, and the implications for Māori leadership practice. The NZQA identified the enactment of Māori leadership practice as a lived reality at the NZQA, and a consequence of that reality a Māori leadership narrative has emerged. In the first phase of the implementation of the Māori strategy, the focus was driven by the external factors that were concerned with the NZQA's role in tertiary education quality assurance and mātauranga Māori. The governance partnership with Ngā Kaitūhono assisted to navigate this tension. The role of the DCE Māori was pivotal in building relationships and developing and implementing the appropriate models and people capacity.

Māori officials working in the two-worlds space need to be self-assured in their own identity and courageous to withstand and cope with the intellectual challenge. They need to be authentic and honest in their assessment of and contribution to the development of the Māori operating framework and its implementation. They are confronted with internal pressures to succumb to the dominant system, and they are left exposed to the external pressures that do not trust the system. It takes people with strong personal 
leadership to withstand the pressure and cope with ongoing stereotyping behaviour that exists in intangible ways.

This chapter shows that the NZQA, based on its recent history, is a site of lived Māori leadership experience. Most if not all agencies' histories contain examples of leadership practice. The NZQA story provides examples of Māori leadership practice at many levels. The case study shares the NZQA experience in such a way that will help others. The key sentiments of those engaged in the study were pride and satisfaction about the progress made, but there was also trepidation and a slight fear of the NZQA losing the gains made when key people leave. The challenge for the NZQA is continuity of practice so the humanistic elements of the NZQA endure. 


\title{
Chapter Six: Discussion of Key Findings
}

\section{Overview}

\author{
Ko te toi o Tūhourangi kai mātaotao \\ i moea ki runga i te takapau wharenui \\ kia puta ki waho taku mana è. \\ The birth-place of Tühourangi \\ Who was conceived on the great mat \\ And so was born, the mana of Tühourangi.
}

(Tūhourangi Auahi Ana E! 2011, pp. 16-17)

In this chapter I have drawn on my whakapapa connection to Tūhourangi and chosen the phrase 'takapau wharanui' (literally, great mat) as a metaphor to describe the foundation upon which layers of knowledge found through lived experience are related to each other. Without a strong foundation, and whakapapa, that such a takapau wharanui exemplifies, further work is without relevance and meaning (Edwards, 2012).

My position in this chapter, as a descendent of Tūhourangi, insider researcher and public servant, is to now place the key elements on the great mat. I have listened to the voices of lived experience and I have been intimately involved in orchestrating and leading the work at the New Zealand Qualifications Authority (NZQA). For the purposes of clarifying and discussing the key elements, I now extract myself from the depths and details of lived experience and I stand back to consider the elements and locate them on the takapau wharanui. I begin to explore how the elements inter-connect and how they may be woven and fit together so they may strengthen the mat, and underpin later arguments and proposals. I use kaupapa Māori as the key analytical tool to achieve this task.

The metaphor of takapau wharanui validates the researcher's analytical stance and use of kaupapa Māori theory, as a sense-making method, 'to help distil the holistic and dynamic elements that reside within this phenomenon' (Jackson \& Parry, 2008, p. 106). The use of metaphor such as takapau wharanui is not uncommon in Māori research. The 
He Awa Whiria (Braided Rivers) model is presented as a model that can be used to reconcile Western science and kaupapa Māori approaches. It creates a constructive 'space' for the two approaches to be located within, sets out a framework for interaction, and concludes with a platform that reconciles the evidence produced. The model is informed by partnership models; validation of the two approaches; cross-cultural communication, interpretation, and negotiation; and a value base that is inclusive, integrated, and empowering (Families Commission, 2013).

Spiller et al. (2010) related the similar metaphor of whāriki to research methodology emphasising Māori values, Māori cultural concepts, and the notion of care. The interwoven whāriki paradigm reflects the reality of the agencies in this study, where Māori leadership competes for space within the wider public-sector leadership (p. 5). The implications for this research is the interweaving of theory, analysis, and diagnosis between two worlds whilst ensuring tangible benefit to Māori communities, and placing Māori values, ways of knowing, attitudes, and practices at the centre of the research (Spiller et al., p. 4).

\section{Introduction}

This chapter places the key findings, thematic analysis, and critical reflections that emerged from two sets of data on the takapau wharanui. I refer to the totality of the first data-set as the 'voices of lived experience'. This includes the initial findings drawn from the initial interviews with five senior Māori officials as part of the Indigenous Peoples Experiences of the Public Sector study approved by the University of Victoria Wellington and the Australia New Zealand School of Government (see Chapter 3, Research Interviews). Also included is the data from the first research wānanga, 19 post-wānanga interviews, and three case narratives. The second data-set is the organisational case study of the NZQA outlined in Chapter Five, including reaffirmation of the initial findings from the second research wānanga with the NZQA Māori staff network. The second wānanga provided an opportunity to clarify any matters of doubt and/or concern about the integrity of the data and key findings.

Using kaupapa Māori as the critical lens, this chapter identifies the relationships between the voices of lived experience and the NZQA case study, and examines and presents 
elements that describe Māori leadership practice in public administration. I use five tables to plot the key findings found in the data. The similarities and differences between the two data-sets are discussed and grouped under three major themes: a) the goal of good governance; b) the change required in organisations; and c) the validation of mātauranga Māori. Finally, I reflect on the takapau wharanui as a potential platform to underpin the distinctiveness of Māori leadership-as-practice (L-A-P).

\section{Summary of Key Findings}

By using tables and explanatory comments, this section summarises four high-level findings, themes, and sub-themes derived from the data. The tables emphasise the voices of lived experience to give expression to the authenticity of concerns that were evident throughout the research process. The four high-level findings are: a) rangatiratangakāwanatanga tension; b) the Māori voice in the public sector; c) recognition of Māori philosophy and practice; and d) the place of Māori in the public sector.

\section{Rangatiratanga-Kāwanatanga Tension}

The first finding relates to space and context, and the fact that the tension between the notion of rangatiratanga and kāwanatanga exists as a reality for Māori public servants. The analysis consistently found that an inter-play of dynamics occurs that is felt as constant biases and contradictions that Māori public servants have to navigate in order to survive and succeed in the public sector. As part of their leadership armoury, Māori officials operating at the two-worlds interface use varying techniques and personal models to withstand and become resilient to these biases and contradictions. They adapt to the various contexts they find themselves in. How they interpret those contexts and develop strategies, either planned or intuitive, is akin to the Māori methodology of leadership practice. Knowledge of, and intimacy with, the two-worlds interface and environment was a key factor in how Māori working in the public sector positioned themselves, and how, as a result of experience, Māori leadership practices have emerged. 


\begin{tabular}{|c|c|c|c|}
\hline $\begin{array}{l}\text { HIGH-LEVEL } \\
\text { FINDING }\end{array}$ & THEME & SUB-THEME & $\begin{array}{l}\text { VOICES OF LIVED } \\
\text { EXPERIENCE }\end{array}$ \\
\hline \multirow{9}{*}{$\begin{array}{l}\text { Rangatiratanga- } \\
\text { kāwanatanga tension }\end{array}$} & \multirow[t]{2}{*}{ Space } & \multirow{2}{*}{$\begin{array}{l}\text { Interpretation of the } \\
\text { context }\end{array}$} & 'Who owns the context?' \\
\hline & & & $\begin{array}{l}\text { 'definition of reality and who gets to decide } \\
\text { reality, who gets to act on that and measure it ... } \\
\text { that's something Māori public servants have to } \\
\text { engage with quite a lot...' }\end{array}$ \\
\hline & Power & Power relationship & \\
\hline & Rangatiratanga & Collective organic & Difference \\
\hline & \multirow[t]{2}{*}{ Kāwanatanga } & High level of organisation & Survival \\
\hline & & Individual & Bias \\
\hline & Two-worlds interface & Clash of values & $\begin{array}{l}\text { 'it is unsafe and compromising, too much } \\
\text { phoniness and rhetoric' }\end{array}$ \\
\hline & \multirow[t]{2}{*}{ Treaty of Waitangi } & \multirow[t]{2}{*}{ Kaupapa intent } & $\begin{array}{l}\text { 'Without manaakitanga institutions have no right } \\
\text { to exist ...' }\end{array}$ \\
\hline & & & $\begin{array}{l}\text { 'To get better government from the } \\
\text { government ...' }\end{array}$ \\
\hline
\end{tabular}

\section{The Mãori Voice in the Public Sector}

The second finding relates to kaupapa Māori and improving outcomes for Māori. The data found that the matter of ensuring the Māori voice was heard in public administration is a constant challenge.

Some participants expressed being cautious and worrying about the weight of expectation to be the Māori voice in government-agency forums, especially as there were not enough Māori voices in government agencies. The study showed that there were times when they felt compromised by the dual measures of accountability and the requirement to do what is tika and pono (right and truthful), and to meet the expectations of the Crown - to be accountable, impartial, and frank in the delivery of advice.

Māori voices resonated with me as a key term to describe the legitimacy of the place of the Māori world view within governmental decision-making processes. This is underpinned by seeing the Treaty of Waitangi as a living entity. Māori engagement is critical whilst operating at the interface of Māori and the Crown. The data emphasised a growing sense of aspiration towards genuine engagement, building platforms, and organisational infrastructure to enable Māori voices to be heard. This was viewed as a positive change that was emerging. Māori leadership practices were changing to be 
relevant in the post-Treaty settlement environment. Māori voices offer, as a general principle, new pathways for better governance, diversity, inclusion, and bicultural futures.

\begin{tabular}{|c|c|c|c|}
\hline $\begin{array}{l}\text { HIGH-LEVEL } \\
\text { FINDING }\end{array}$ & THEME & SUB-THEME & $\begin{array}{l}\text { VOICES OF LIVED } \\
\text { EXPERIENCE }\end{array}$ \\
\hline \multirow[t]{7}{*}{$\begin{array}{l}\text { The Māori voice in the } \\
\text { public sector }\end{array}$} & $\begin{array}{l}\text { Better outcomes for } \\
\text { Māori }\end{array}$ & $\begin{array}{l}\text { Changing relationship } \\
\text { pattern }\end{array}$ & $\begin{array}{l}\text { From 'no ability to influence policy - a waste of } \\
\text { time' to 'is the public-sector brave enough for } \\
\text { Mãori thinking and diversity?' }\end{array}$ \\
\hline & & & $\begin{array}{l}\text { 'We believe in good government and good } \\
\text { governance, it's our choice to work in } \\
\text { government to bring about change ...' }\end{array}$ \\
\hline & & & 'Comes back to where power and influence sits ...' \\
\hline & & & 'Who leads the bicultural conversation?' \\
\hline & Engagement problem & Recognition & 'rooted in those principles of community' \\
\hline & & & $\begin{array}{l}\text { 'the power of how Māori engaged with their own } \\
\text { people in a totally different way' }\end{array}$ \\
\hline & & Treaty of Waitangi & $\begin{array}{l}\text { 'We don't like to argue about the Treaty, but like } \\
\text { to lead a conversation on being bi-cultural ...' }\end{array}$ \\
\hline
\end{tabular}

\section{Recognition of Māori Philosophy and Practice}

Implicit in the key finding about Māori voices is the related finding that Māori public servants create the reality of mātauranga Māori within public administration. Māori public servants bring their deliberate acts of leadership into the public-sector space and create Māori contexts in other leadership environments. The practice of tikanga is hugely important in this respect. Tikanga Māori elements of pōwhiri, whaikōrero, waiata, haka, taonga, toi Māori (Māori art), karakia, whakapapa, rāhui (ritual prohibition), and whakataukī are unique to Aotearoa New Zealand, and are found in public administration. Each element has its own deep and rich epistemological foundation, experience, history, and narrative. Māori leadership practices keep spaces open for these elements and the recognition of Māori ways of knowing, doing, and leading. 


\begin{tabular}{|c|c|c|c|}
\hline $\begin{array}{l}\text { HIGH-LEVEL } \\
\text { FINDING }\end{array}$ & THEME & SUB-THEME & $\begin{array}{l}\text { VOICES OF LIVED } \\
\text { EXPERIENCE }\end{array}$ \\
\hline \multirow[t]{8}{*}{$\begin{array}{l}\text { Recognition of Māori } \\
\text { philosophy and practice }\end{array}$} & $\begin{array}{l}\text { Legitimacy of kaupapa } \\
\text { and mātauranga Māori }\end{array}$ & $\begin{array}{l}\text { Compatibility with Māori } \\
\text { values and practices }\end{array}$ & $\begin{array}{l}\text { 'Kaupapa Māori becomes a codified regime ... } \\
\text { people feel they have to comply' }\end{array}$ \\
\hline & & $\begin{array}{l}\text { Consistency with Māori } \\
\text { expectations }\end{array}$ & 'No connection to kaupapa intent ...' \\
\hline & & \multirow[t]{2}{*}{ Complementary } & $\begin{array}{l}\text { 'Kaupapa Mãori is the dominant feature, our } \\
\text { manaakitanga responsibility ...' }\end{array}$ \\
\hline & & & $\begin{array}{l}\text { 'The government do not fully comprehend the } \\
\text { obligations that come with Māori concepts ...' }\end{array}$ \\
\hline & & $\begin{array}{l}\text { Being shaped by } \\
\text { whānau upbringing }\end{array}$ & $\begin{array}{l}\text { 'Keeping it real ...' } \\
\text { 'Get back home ...' }\end{array}$ \\
\hline & & \multirow[t]{2}{*}{$\begin{array}{l}\text { Philosophy of } \\
\text { engagement }\end{array}$} & $\begin{array}{l}\text { 'A kaupapa, a tikanga, the thing they can all agree } \\
\text { on ...' }\end{array}$ \\
\hline & & & 'Sense of responsibility ...' \\
\hline & & Learning journey & 'Kia ū ki te whakapono kia aroha ki a koutou' \\
\hline
\end{tabular}

\section{The Place of Māori in the Public Sector}

The three previous findings uncover the question about whether Māori have a place in the public sector. First, Māori operate within a continuous tension-filled context underpinned by machinations of bias; secondly, there is a constant challenge to ensure Māori voices are heard; and thirdly, the reality is that Māori world views are not given equal recognition. Māori are left to question, 'do I belong?' Despite this high level of angst and trepidation, the data found excellent evidence that when Māori find their feet in the public sector they do extremely well. The data showed that it is important to know why you choose to work for the government and accept that you have made those choices for the right reasons. It takes time. Some people do not settle within themselves, and they feel so compromised they choose to leave or end up making poor decisions. 


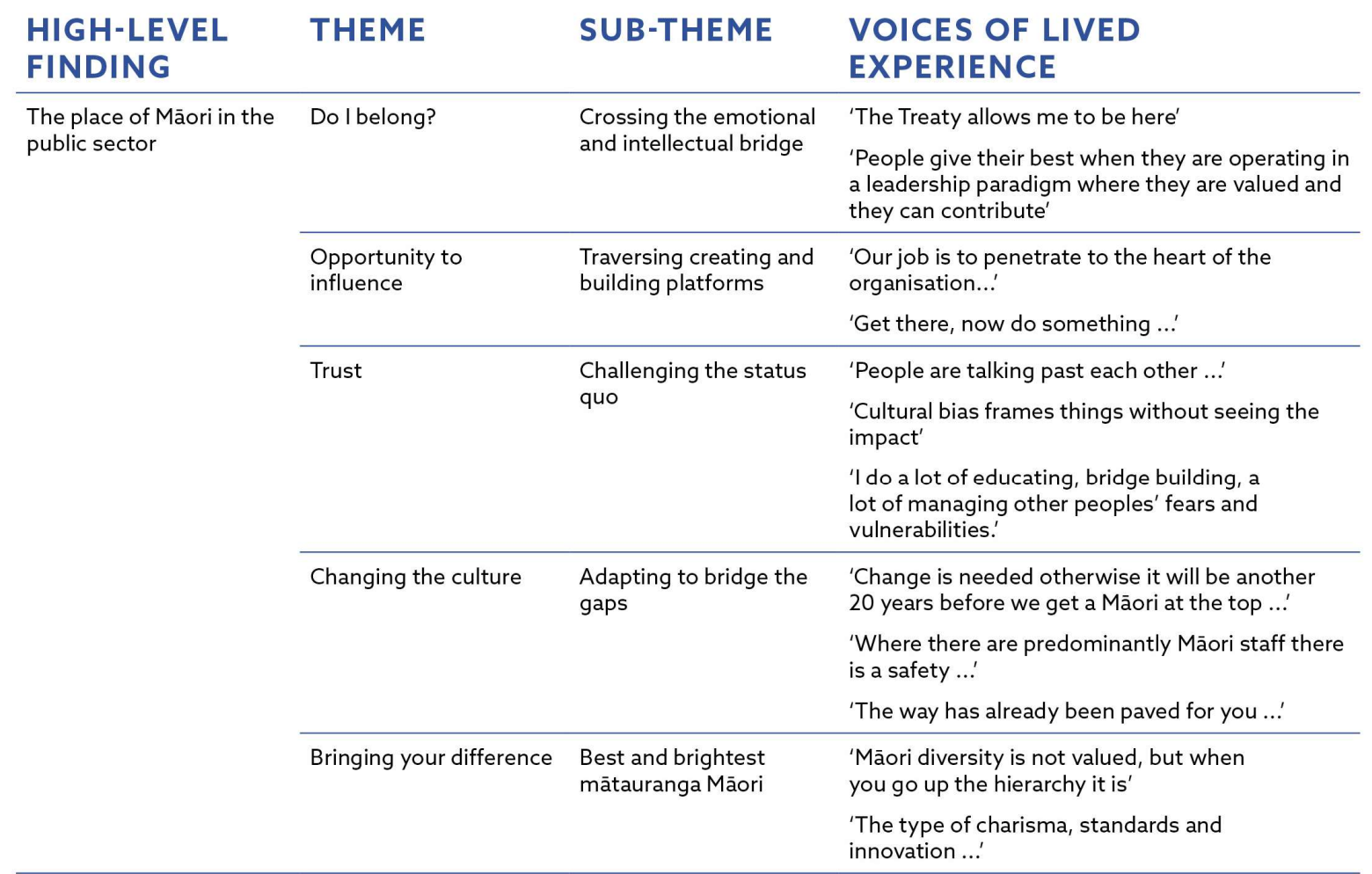

\section{Thematic Analysis}

Using the data-sets from the voices of lived experience and the NZQA case study, this section discusses the key findings that emerged and discusses them under three key thematic headings. This section allows the reader to understand some of the underlying intentions and motivations to explain what Māori leadership is in a public-sector context.

\section{The Goal is Good Governance}

The first theme is the goal of good governance. Underpinning the practice of Māori leadership is an inherent responsibility to ensure government agencies are meeting their obligations and responsibilities to the Treaty of Waitangi and delivering better outcomes for Māori. The analysis of the data found that people know it is right that Māori should be involved in decision-making and developing the structures necessary for engagement. The critical leadership practice is to involve the right people across the country who can put into action the rangatiratanga-kāwanatanga principle, which is to achieve good governance. The critical element emerging from the data was the notion of organisation- 
building as a function of Māori leadership practice. This included using deliberate methods to influence, shape, and change the way government agencies engaged with the Māori world.

Also underpinning this theme is the emergence of critical competencies to be able to interpret the spaces within which you operate in the public sector. The findings reinforce the dimension that Māori operate within the public sector under circumstances of overriding system dominance. This imposes a strong feeling of operating under constant challenge and scrutiny. Participants indicated that, in their life experiences, there was always a challenge to keep intact the elements of the Māori world that were important to you. The kāwanatanga context is at times an uncomfortable, tense, and culturally unsafe space to work in. Lived experiences show stages of feeling isolated, with no ability to influence, and not being valued. However, those experiences also equipped people with the competencies to understand how to move in and mobilise people and resources in those contexts and show leadership.

Good governance requires Māori in the public sector to counterbalance the weak position Māori occupy at the Crown-Māori interface. This requires a subtlety in leadership practice that is about the courage and nous to be able to express what is important for Māori. One participant commented that it is about 'having the right partnerships working together to deliver the best outcomes for Māori and citizens' rights - they are entitled to get the best service possible'.

The analysis found elements that speak to the goal of good governance. For example, the Treaty of Waitangi and the principle of partnership mean a great deal and emphasise engaging in equitable and reciprocal processes. The key point was an aversion towards the domains of compliance and ticking the box on consultation processes. Leadership in a modern environment requires gaining a deeper understanding about what good looks like and what success looks like. It is the process that moves people and agencies towards a constitutional and equitable right to partnership that is important. The study identified that partnership occurs when trust is present and there is confidence in each other to make the right decisions on behalf of both parties. Moreover, a fundamental part of 
progressing a Treaty-based partnership is constant awareness and effort to ensure tikanga Māori is not compromised or disenfranchised, in public-sector settings.

The voices of lived experience found there is a noticeable shift in how Māori in the public sector think about Māori leadership and the role of government agencies. Lived experience is telling us the post-Treaty settlement discourse has shifted conversations away from issues of grievance and mistrust towards a discussion about new modes of governance, futures planning, shared decision-making, and influence. There is a new dynamic focusing on relationships, collaboration, and engagement. The behaviour of government agencies has shifted somewhat, from cultural weakness when engaging with Māori feeling the need to 'dial a kaumātua' for cultural leadership towards recognising a greater need for executive Māori leadership. The NZQA case study re-affirmed this shift and provided a living example of an agency enacting leadership by reframing conversations. The case highlighted how a Māori partnership with a government agency might achieve this by recognising past, present, and future models, and recalling Māori histories, knowledge, and wisdom to move inevitably forward, as well as understanding the machinery of government and the global socio-economic context. The core themes identified positioned Māori L-A-P as:

- a strategic endeavour

- a collective endeavour

- building trust and confidence

- supporting other leadership environments

- premised upon tikanga practice.

\section{The Change Required in Organisations}

We've been able to create a structure right through the organization which is quite powerful.

(Research participant)

The second theme the study found is a growing sense that change is required in organisations. There was a strong view that certain dynamics are cemented in publicadministration structures and systems that restrict recruitment, progression, and the development of Māori in the public sector. Furthermore, there is a lack of appropriate 
support and development for Māori to be attracted to and stay in the public sector. The data included comments from a small number of Māori officials who had worked for iwi authorities who were employed in senior positions in the public sector. The transition was not easy for those with limited understanding of the machinery of government and of how the systems work. As a result, some felt disillusioned with the process and lack of support and were not able to make the contribution and difference that they were hoping to make. They were challenged emotionally, culturally, spiritually, and professionally.

Agencies such as the NZQA and the New Zealand Police have shown that creating an organisational environment and structure that is inclusive of kaupapa Māori perspectives is indeed possible. The change referred to in the findings included examples of taking Māori strategies seriously, distributed leadership models, efforts to improve cultural capability, and developing key relationships with Māori.

The study found the change in job titles such as that for the role of Deputy Chief Executive Māori at the NZQA represented a strategic and symbolic shift to say the implementation of Māori strategies and fulfilment of obligations to deliver services to iwi and Māori is important. The introduction of senior executive Māori roles has meant executive leadership teams have become broader in their thinking and focus on the strategic position, iwi relationships, and evidence of Māori around the system. However, this practice is still not widespread, as exemplified in the case of the Department of Corrections, where the senior Māori role was a tier 3 role and unable to exert the level of influence that a tier 2 role can. There was a pervading view that the public sector is still slow in organisational change and developing Māori leadership capacity, which in turn constrains how agencies respond in an evolving post-Treaty settlement environment.

One of the lurking issues repeatedly raised throughout the study was general disillusionment with Māori public-servant recruitment, leadership development, and career progression. Participants highlighted that there is a handful of Māori currently in tier 2 public-sector management roles. Participants could literally identify and count them on their hands. There was also a lack of tier 2, 3, and 4 Māori managers with accountability for the key levers of implementation and resource allocation. 
There is change required in organisations in terms of the way Māori are recruited into the public sector. There is a strong feeling that Māori are not recognised for the cultural competencies they possess. Recruitment panels tend to recruit based on Western formulas, prioritising operational experience in managing large budgets, staff numbers, and large complex policy projects or services. There is a challenge to impress upon recruitment panels the value and contribution of Māori cultural competencies, such as the Māori language and operating at the interface with Māori, and the added contribution these things bring to the public sector over and above professional skills, qualifications, and technical capabilities. The point was made that leadership, influence, relationships, and operating nous comprise our inherent capability. One research participant commented:

People were recruited into roles because they had brains and understood the policy process. They knew a lot but they couldn't do a lot. The appointment of Māori practitioners gave you that balance because in our tikanga you actually have to do stuff for the people.

There is a need to ensure more Māori officials are represented in positions that prepare them for larger roles and with sufficient decision-making authority to make a difference. As one participant commented: 'More Māori leaders should be in mainstream roles with decision-making authority, rather than Māori advisory roles. Advisory roles are important, but there needs to be a shift'.

Building on from the arguments about recruitment, the findings noted that the role of Māori leadership in public administration is no longer solely in the realm of tikanga, but is considered a strategic function - a mode of governance and management. The themes of good governance and change were aligning to suggest that practitioners are strategic all of the time, and apply influence and communication as key tools for transformation. Practitioners are able to balance the understanding of tikanga practices and protocols, such as pōwhiri, and are effective in carrying out the roles and practices of executives and public administrators. Leadership practice is moving towards an integration of cultural understanding, strategic operating skills, and action-orientation that positions organisations, rather than individuals, towards improving Māori responsiveness and fulfilling the obligations of the Treaty of Waitangi. 
Further to this, the collective narrative voiced frustration at the limited understanding of Māori values, Māori perspectives, and Māori leadership capabilities among agencies, and particularly the ability to influence. The State Services Commission (2016b) identified 'influence' as the biggest weakness within public sector leadership. There was a strong feeling among participants that experienced Māori public servants have an inherent ability to influence, but, again, there is a problem in getting this message across to recruitment panels.

'People who are on appointment panels tend to appoint people who are like them.' 'The ceilings, blocks and limited appetite for risk is constraining progression and growth through the system. This is a recruitment issue.'

(Research participant)

The study found that research participants were puzzled as to why there is no formal system to support Māori leadership development in the public sector. They felt it is important leadership development includes the transmission of Māori leadership knowledge and related experiences, concepts, and practices within the context of a modern post-Treaty settlement public administration. Yet despite this, there was a strong view that Māori governance and leadership has a critical role to play in the future of New Zealand public policy and administration.

\section{The Validation of Mātauranga Māori}

Both sets of data, the voices of lived experience and the NZQA case study, established that mātauranga Māori culturally locates Māori L-A-P. The acceptance of mātauranga Māori into organisational life and into the everyday activities of Māori and non-Māori staff created positive culturally inclusive environments. As people became more aware and cognisant of Māori world view perspectives, there was a greater appreciation of Māori ways of leading, including the expressions of kaupapa Māori values.

Both sets of data identified that Māori public servants draw upon their knowledge sources, from their iwi base or generic mātauranga Māori (Doherty, 2012), and fill their 'kete' (basket) with this knowledge and experience to draw upon it as required to provide 
Māori perspectives on issues. The study identified that mātauranga Māori underpinned leadership practices in various individual, collective, and organisational contexts.

At an individual level, the narratives were consistent in the view that Māori in the public sector hold fast to Māori identity and accept roles in the public sector that align with their personal ambition to improve Māori wellbeing, economically, socially, and culturally. To achieve this, the participants emphasised that recognition and legitimacy of what Māori know as leadership practice is critical if Māori, as Māori, are to take a rightful place in public administration.

Māori working in the public sector adopt their own personal Māori models that consist of values and whakataukī and philosophies that are important to them. They apply these models in very personal ways to keep themselves grounded and safe. There is no one way or right way. These models are deeply intuitive and personal for both the individual and their whānau. Māori public servants do not say, 'today, I am going to apply tika, pono, and aroha'. They just naturally apply Māori values in practice and hold themselves personally to account for this. It makes them feel confident to operate in a kāwanatanga space. There are many Māori concepts accessible to Māori, and participants would 'pick and choose' the ones most pertinent and meaningful to them. The research found that using valuesbased models is a form of leadership that demonstrates an expression of kaupapa Māori in a naturally occurring and inspiring way.

Māori and indigenous concepts are hugely vital in the way people interact.

(Research participant)

There was a consistent view that normal everyday things that you do at home, at the marae, or in a whānau environment are also applicable in your work life, and that, as Māori, you do things that may seem different and at times awkward but for Māori are natural, such as singing after someone makes a speech. Statements within the voices of lived experience and the NZQA case study articulated a view that, as Māori, 'you don't turn off your mātauranga Māori at the end of the working day' (research participant). 
The data consistently showed that living by Māori values is a personal commitment. At a personal level, Māori in the public sector live by Māori values that have been shaped by their own authentic selves, their connections to whānau, and their upbringing. Māori values guide and inspire people to think from a Māori world perspective.

Māori feel a responsibility to steward the practices and legacies of those who have gone before us into the modern world. The study also highlighted that Māori values are human values, as shown in the NZQA case study, and they have an influencing effect and transcend into organisational culture and staff behaviour.

At a collective level the data-sets were similar in the way they expressed the notion that knowledge of Māori world views needs to be sustained and expressed in an authentic and meaningful way. How leadership occurs in public administration ought to draw on Māori world views to consider other ways of solving wicked problems. There was a common understanding about the way leadership practices of Māori leaders such as Sir Apirana Ngata, articulated wisdom through waiata, whakataukī, and pūrakau (stories), and how that would inspire the next generation and create a platform to think about the world differently. This theme suggests the current generation can only imagine and try to make sense of those legacies and learn what we can. We ask, what were they thinking? What clues can we take from the legacies they left for the future generations?

At an organisational level, mātauranga Māori and the expressions of kaupapa Māori values can be seen as tokenistic; hard for non-Māori to grasp conceptually and difficult for them to understand because they do not understand the Māori world view. Māori public servants are very generous with their Māori knowledge, and contribute that knowledge in all kinds of organisational environments. They contribute diversity of thought based on Māori world views and leadership experiences in other contexts. They seek to ensure all practices follow tikanga Māori and implement corrective action to ensure Māori values are safeguarded. The data strongly present a case that Māori public servants create and support leadership environments though mātauranga Māori. In doing this important work, they are in effect validating mātauranga Māori. 
Māori elements are not exclusive, they are inclusive of other leadership elements; however, the practice is to bring those elements together to create a leadership environment that is contextually right for the organization.

(Research participant)

\section{Similarities and Differences Across the Data}

This section discusses the similarities and differences between the voices of lived experience and the organisational case study of the NZQA. Both sets of data are consistent and purposeful in driving a kaupapa Māori agenda within the public sector. The voices of lived experience traversed a wide and deep knowledge base and expressed the importance of Māori leadership and Māori world perspectives in the public sector. The NZQA case study confirmed that issues and concerns raised by the voices of lived experience are similar to leadership experiences within an agency. The NZQA case study provided a guide of how Māori leadership practices might be considered, and enacted, within a government agency setting. Both data-sets revealed consistent and powerful threads that expressed a collective view about the reality of the context and space for Māori within the public sector. This thread focused on the issue of place and the challenges and opportunities for Māori leadership practice in the public sector.

At the level of the individual voices of lived experience, the data underscored how personal the issue of Māori leadership is. This was highlighted when participants shared experiences, such as how whānau relationships were compromised by agencies, how conflicts of interests affected career decisions, and the struggle to be yourself in the public sector. Positive experiences were also shared, such as the role a person plays in strengthening whānau, how to challenge the status quo and pave the way for others, and how to add richness through stories and diverse thinking.

At an agency level, the NZQA case study emphasised how important organisational positioning is in relation to creating an authorising environment that is open to engaging with the Māori world. The case study provided examples of the impact on Māori influence and thought leadership on a government agency with respect to philosophies of 
engagement, transformation, and relationships. Issues of Treaty partnership, relationships, and transforming organisations dominated the narrative.

There was consistency across the data with respect to Māori perspectives shaped by whānau upbringing and values, and leadership practices such as being connected to home. Māori leadership practice in public administration is mirrored as Māori leadership practice in whānau life - the sense of action-orientation (supporting whānau, hapū, and iwi or kaupapa such as sport, kapa haka, and trusteeship roles) and the sense of cultural authenticity (with respect to being connected to marae, hapū, or iwi affairs, or te reo Māori revitalisation).

The key difference between Māori leadership and other forms of leadership in the public sector is that Māori public servants choose to bring (or not bring) their deliberate acts of leadership, including their knowledge of the Māori world, into the public sector. Agencies need to create an environment for Māori leadership and be prepared to invite the essential elements of the Māori world into organisational life. The key similarities are the shared stories and the high-level thinking, analysis, and worry about the place and (lack of) relationships between Māori (and the Māori world view) and government agencies. This shows how much Māori leadership practice in public administration is a collective endeavour; it is very strategic and underpinned by tikanga and kaupapa Māori.

\section{Reflections from Kaupapa Māori Perspectives}

This section reflects on the findings through the critical eye of kaupapa Māori and the connection back to the Māori world and Māori knowledge base. The four sub-headings are; rangatiratanga, whanaungatanga, manaakitanga, and kaitiakitanga. This section aims to help readers and public-sector leaders understand how the elements link together, so that, in effect, it creates a kaupapa Māori view of leadership in public administration. The analysis aims to provide a starting place for all leaders in the public sector to be able to engage with the Māori world. 


\section{Rangatiratanga}

In Chapter Three, I explained the lens of rangatiratanga as 'autonomy realized through the enactment of a Māori world-view in response to the aspirations and driving motivators of whānau, hapū and where relevant, the Māori community and sector stakeholders' (NZQA, 2017). The study clearly finds expressions of rangatiratanga leadership. The expression of rangatiratanga is achieved when Māori are confident in their space and place within kāwanatanga.

Rangatiratanga implies a stance of a) transforming the space; b) having a voice; and c) legitimacy. Transforming the space recognises that spaces within public-sector contexts are filled with tension and are uncomfortable for all those involved. This means leadership emerges through the ability to operate and adapt in those contexts, and this is evident when Māori voices are present and acknowledged. Rangatiratanga leadership in public administration is about an action-orientation to weave together the appropriate people and processes, usually involving tikanga Māori, to build relationships and strategies for engaging with Māori. This involves creative thinking, navigational skills, and the ability to traverse places and spaces for kaupapa Māori and mātauranga Māori to have valid expression and legitimacy. Rangatiratanga leadership in this context involves contributing to leadership environments through engagement, education, communication, and advice to support people towards a state of understanding and enlightenment about the Māori world. Through this study, I have identified rangatiratanga leadership practices in public administration that link to understanding Māori aspirations and motivations. This is a non-exhaustive list that can be added to.

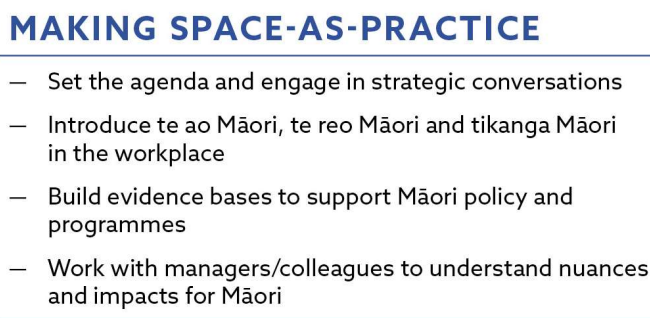

NAVIGATING SPACE-AS-PRACTICE

- Identify opportunities and seek mandates to innovate and try new things

- Broker and network with others to test ideas in different places and spaces

- Help others to change their mindsets towards Māori

- Move through the system to find ways to get better results 
The study found that Māori public servants who express rangatiratanga are firm and make conscious decisions about their place in the public sector. They understand the machinery of government. They know why they are working in the public sector, and they are fully aware of their right to be there. They withstand the negativity and pressure from Māori who consider that they are Māori bureaucrats, with colonised minds. They clearly set out to make a difference for Māori in their roles. Their stance of rangatiratanga connects them to their home base, which serves to protect and advance a Māori world view. This enables them to be aware of the pressures and biases that exist in the public sector. They bring with them passion, ambition, and aspirations to contribute to whānau, and Māori social, cultural, environmental, and economic development. Research participants shared decisions they made as to whether to bring personal knowledge of the Māori world and networks into the government interface. There is a pattern of growing confidence to express rangatiratanga by articulating a Māori voice in government agencies as a transformational element.

Kaupapa Māori scholar Graham Smith focused on the term 'transforming' and said that 'change needs to be constantly engaged with, and we should be continually transforming ourselves and our experiences' (Smith, 2015, p. 113). The voices of lived experience confirmed the expression of rangatiratanga also involved public servants embarking on journeys and pathways to be that change. The expression of rangatiratanga would occur in examples of how Māori culture and language would influence the organisational environment; how agencies consider more culturally appropriate ways to engage and develop relationships with Māori; and how senior leaders and managers within agencies would take greater responsibility to ensure opportunities to engage with Māori when codesigning and developing public policies and services.

The study identified that, as an expression of rangatiratanga, an emerging purpose for Māori leadership could be defined as everyday actions taken to advance mātauranga Māori and kaupapa Māori. This purpose implies that a multitude of actions follow a kaupapa (a plan of action), performed by a collective of leaders, producing a momentum of change and transformation. 
In Chapter Three, I explained whanaungatanga as 'connecting, fostering, and maintaining relationships based on respect, integrity and understanding for the benefit of all' (NZQA, 2017). The study finds the practice of whanaungatanga enables public servants to connect to the Māori world and engage with others from within a context of cultural identity. The study identified that whanaungatanga is an important leadership practice to a) engage with Māori; b) build relationships; and c) support and look after others. The practice of whanaungatanaga should be possible without having to make sacrifices or trade off other practices or processes.

The study showed practitioners frame and position the leadership experience within a context of Māori values that express a Māori heart, engendering an understanding of the holistic Māori perspective and cognisant of all of the elements working simultaneously. Tikanga Māori practice, and specifically the practice of kanohi kitea, requires the practice of karakia (prayer) and mihi (greetings) at the start of the day or meetings to acknowledge and build relationships and to invite spiritual elements into an environment.

Karakia means different things to different people and therefore the reasons why and how people participate in karakia varies. Karakia delivered in te reo Māori seeks to unify those present and to bring a sense of deliberate mindfulness to the kaupapa for which blessings are being sought. It provides a moment for reflection and for giving thanks. As a leadership practice, karakia signals an appreciation of something that is bigger than the individual and acknowledges a higher purpose. The interpretation suggests that if spiritual elements are not present, the context is void of meaning. Tikanga elements within a leadership practice environment are vitally important to enable people to feel safe and to make connections.

The study found that whanaungatanga is central to the engagement experience, and that Māori public servants operate in a cultural paradigm that places everyone equally, as a whānau. 
The study also found that Māori contribute cultural elements to other leadership environments and that because they know the Māori world they have an ability to lead bicultural conversations. They navigate relationships with ministers, chief executives, policy-makers, and regional and front-line staff, and with Māori, whānau, hapū, iwi, and a multitude of organisations. The leadership competency is communication and the ability to articulate key messages and adapt to different contexts and situations. The study found that Māori public servants are active in negotiating spaces, recognising difference, developing common understandings, co-creating and co-designing solutions, and co-constructing reality through feedback loops to Māori. The stories and reflections of the voices of lived experience indicate Māori public servants are engaged in a whanaungatanga (as a leader-follower relationship) mindset all the time. The organisational hierarchy, position, or status did not determine the extent to which whanaungatanga occurred. Māori public servants would bring their own personal capacities into the leadership environment. They would ensure critical relationships are managed, and be supportive, caring and compassionate.

The study also found that when whanaungatanga was not understood or present in their working environment, and where there were no obvious places to get support, Māori working in the public sector felt lonely, isolated, and empty. Whilst whanaungatanga was an important element in their daily lives as Mãori, they found that the public-sector environment was not a natural place for whanaungatanga to be enlivened. Māori public servants would find their own way to be Māori, by being involved with Māori staff networks, participating in the annual public sector kapa haka event, Te Konohete, or networking at the local pub or café. The research participants felt there were no recognised portals for building relationships and opportunities for self-care and cultural nourishment as Māori. There is no co-ordinated, systemised, or formal approach to building Māori capability and whanaungatanga across the public sector. As one research participant commented:

There is no infrastructure to wrap around and support. So, you question, is the system for us? You think 'bail out'. Can we adapt and how flexible can the system be to allow us to show Māori leadership? 


\section{Manaakitanga}

In Chapter Three, I explained manaakitanga as 'realised by mana enhancing behaviour and practices for the care of ākonga, whānau, hapū, iwi and community' (NZQA, 2017b). This study identified manaakitanga is a critical leadership practice and balancing tool in public administration. The key element is the need to care.

Manaakitanga is expressed in public administration through developing a range of mechanisms, such as Māori strategies and engagement forums, demonstrating the position that agencies take to caring about key issues for Māori. The study found that the NZQA has a compelling story to say they are meeting expectations and obligations for public sector agencies to act in accordance with the principles of the Treaty of Waitangi. The study also found that organisational leadership plays a critical role in balancing rangatiratanga and kāwanatanga relationships, and the expression of manaakitanga goes a long way towards building sustainable relationships with Māori. Numerous examples emerged from the data that indicated when manaakitanga is present, such as when engaging in dialogue, acknowledging the work of past leaders, or pouring a cup of tea.

Manaakitanga is important from many perspectives. The expression of manaakitanga flows continuously between the actors involved in the engagement process and recognises the influence of mana - which resides within those actors. Therefore, the presence of mana in any forum requires certain leadership practices to be undertaken which are associated with the enhancement of that mana. In Māori engagement settings, the appropriate application of tikanga Māori becomes a critical tool to recognise, acknowledge, and respect mana. Māori leadership practices require practitioners to understand why, when, what, and how (and to whom) to apply the appropriate tikanga practices in order to express manaakitanga. This knowledge element is a critical difference in Māori leadership in comparison with other forms of public sector leadership practice.

Senior Māori officials are attuned to working within a consciousness that the system is not equal, barriers do exist, and the system will not automatically bow to Māori ways or ideas. Māori officials are actively engaged in work to alleviate bureaucratic pressures and 
to find administrative solutions to real-world problems. The study found a strong sense of responsibility to ensure Māori issues do not get missed, swept under the carpet, or ignored. This demonstrates that Māori in the public sector consider manaakitanga to include ongoing concern to care for and look after the Māori world view within the dominant culture.

The study showed that Māori public servants think deeply about the relationship between Māori and the Crown, Māori development, and having dual accountabilities. They are totally committed to Māori and working for the government, and providing advice from a Māori perspective (Katene, 2013, p. 174). Māori public servants, as in the case of Parekura Horomia, are very much embedded within their practice (Gardiner, 2014, p. 421; Raelin, 2011, p. 196). They search for meaning through social interactions and concerted, collective action (Gronn, 2002). They are very conscious of the responsibility to do the right thing and to understand how the system works and their place within it. They think deeply because, as is evident in lived experience, they care about what they do and care for the people involved.

\section{Kaitiakitanga}

In Chapter Three I explained kaitiakitanga as the 'preservation, guardianship and enhancement of the world and its treasures for the benefit of all' (NZQA, 2017). This study identified that kaitiakitanga is a concept that is taken seriously in the public sector, but commands greater emphasis with regards to indigenous Māori issues relating to the preservation and sustainability of taonga (Harmsworth \& Awatere, 2013). The NZQA case study identified that the kaitiakitanga responsibility in relationship to mātauranga Māori and tribal knowledge requires clarification, as Māori appointed to the strategic Māori advisory group did not want to be referred to as kaitiaki. This raises a question: if other Māori are apprehensive about being referred to as kaitiaki of the taonga of others, then what is the kaitiakitanga responsibility of the Crown?

Marsden's (1992) paper on kaitiakitanga clarified the Māori world view position of kaitiakitanga, in relation to the cultural and spiritual decisions of Māori concerning their taonga. Marsden defines 'tiaki' as 'to guard', with other closely related meanings: 'to keep, 
to preserve, to conserve, to foster, to protect, to shelter, to keep watch over'. Kaitiaki is a guardian, keeper, preserver, conservator, foster-parent, and protector. Kaitiakitanga is defined in the Resource Management Act 1991 as guardianship and/or stewardship (Marsden, 1992, p. 15). The research found that the practice orientation of leadership removed the dilemma of who the steward (or kaitiaki) is, and instead highlighted the importance of the leadership role from the perspective of kaitiakitanga as an active rather than passive relationship involving the protection of the place of Māori world views (Marsden \& Henare, 1992).

The study found that Māori officials are very engaged in conversations about living by Māori values and tikanga Māori practices, and ensuring obligations to the Treaty of Waitangi are met. Kaitiakitanga is an important concept to understand when facilitating or reconciling the various elements and inter-dynamic relationships between Māori and the Crown. The work occurs in an environment that is dynamic and evolving, with Māori issues such as kaitiakitanga constantly bumping up against Western philosophies and concepts. These conversations occur as an everyday practice. The study found that tikanga Māori and concepts such as kaitiakitanga are elements that iwi (Māori tribes) hold onto.

'when the tribes came together they said don't poison the water, the water flows; it delivers freshwater to our tribes. What's the one thing they all agreed on and not compromise on'? (Research Participant)

There are times when conversations are difficult to follow because there is something in someone's head - a kaupapa, a tikanga, that is connected to Papatūānuku (Earth Mother) and Ranginui (Sky Father), and the atua Māori (the Māori gods). Māori leadership practice in public administration requires practitioners to have more than a cursory level of knowledge about kaitiakitanga. Through understanding kaitiakitanga a wider plethora of Māori world perspectives and concepts is accessible, and a greater empathy for Māori value is realised.

The four kaupapa Māori perspectives of leadership provide the platform to identify the critical differences and specialisations within Māori leadership practice in public administration. The critical way to consider this platform is to realise that the four 
perspectives are all inter-related, and they each work together in harmony to create a Māori experience. The underlying theme this study has identified is that expressing Māori voices in public administration relates directly to the practice of rangatiratanga, whanaungatanga, manaakitanga, and kaitiakitanga. The study showed that there is a general lack of understanding and a level of ambivalence towards Māori world views in government agencies. It is only through Māori leadership practices and the collective effort of Māori in the public sector that agencies will become aware and educated about kaupapa Māori.
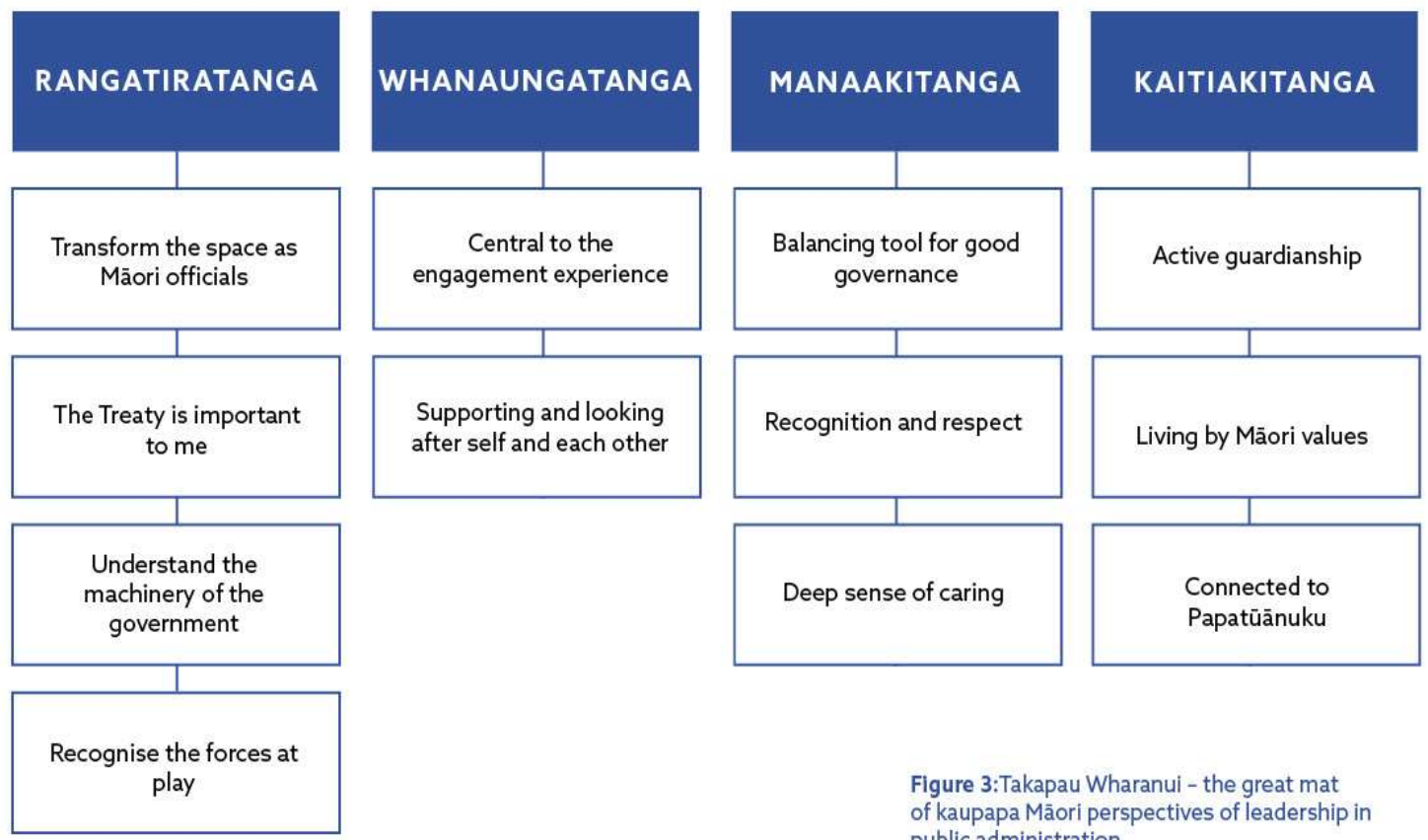

Figure 3:Takapau Wharanui - the great mat of kaupapa Mãori perspectives of leadership in public administration

\section{What is Māori leadership-as-practice (L-A-P)?}

Based on the key findings and the kaupapa Māori perspectives of leadership as shown in the takapau wharanui, this section elaborates on the connection between what I have found thus far and L-A-P (Raelin, 2011). Making this connection gives an enriched and authenticated description of what Māori L-A-P is within the context of public administration, with the emphasis on 'Māori', associated with the emerging notion of LA-P (Raelin, 2011). 
Practice epistemology and the movement towards L-A-P, with its emphasis on leadership as a focus on social interactions and behavioural change within organisational life, signal a slight shift in focus for Māori leadership (Crevani et al., 2010). Katene (2013) describes and categorises Māori leaders using terms such as 'transformational', 'organic', and 'servant'. He casts Māori public servants as 'conservatives'. He profiles individual Māori leaders from the 28th Māori Battalion, and the wave of Māori academic leaders, highlighting their honours, beliefs, and achievements.

Based on this study, I argue that in a modern and global context, including within the public sector, society can no longer afford to consider Māori leadership in the context of who the Māori leader is. The study reveals that Māori public servants are not concerned with the promotion of individual Māori leaders, or the need to find the next Māori leader. What they are interested in are legacies of past Māori leaders, what works, and the opportunities for the future. They want to take it to the next level. They are interested in how a modern public sector builds bridges between people, co-ordinates competing interests, collectivises and mobilises around issues, and facilitates between Māori and the Crown. The research found that Māori who work in the public service do bring Māori leadership, as articulated by one participant who commented:

'We are looking for connections as everything is always connected to something else. Joining key actions, connecting people, we do it well. We are political. We understand how it works. We spend time on it. Working out how to win the war, which battles to choose, it's kaupapa thinking'. (Research participant)

The L-A-P movement indicates that practices unfold through day-to-day experience, and depicts collective action emerging from mutual, discursive, sometimes recurring and sometimes evolving patterns in the moment and over time among those engaged in the practice (Raelin, 2015, p. 6). The voices of lived experience indicate that this notion is much closer to the reality of operating at the interface of Māori and the Crown. There are no shining stars - only humble, hardworking, and committed Māori officials who, daily, seek to advance kaupapa Māori (and improved Māori outcomes) within the bureaucratic framework. But what is this leadership they bring to the public sector? This study finds that Māori in the public sector do not regard 'leadership' as a property of individuals, but 
a property of work practices and processes, done in a certain way, and in accordance with certain principles and values.

The study finds that there are clear differences between Māori leadership and other forms of leadership, such as examples of how Māori cultural practices are carried out, within government-agency environments, and in a variety of settings in which Māori cultural practice remains pre-eminent, such as on marae, at tangihanga, at major cultural events such as Te Matatini (the national Māori performing arts event) and Koroneihana (Coronation celebrations within Tainui tribes), and welcoming guests. Practices such as whaikōrero, hui, and pōwhiri are tangible expressions of traditional Māori leadership that are immediately recognisable in the public service. The intangible element, observed by Māori, is the transferable skills and leadership discipline related to organising and processing capacity. The key performance element is the innate ability to ensure critical roles and functions are operating collectively and seamlessly, without fuss. At large gatherings, such as tangihanga, the host tribe generally has no idea how many people will arrive, or how many groups they will have to welcome onto the marae, and need to ensure tikanga practices such as karanga, karakia, whaikōrero, and hongi are conducted appropriately. Also critically important is how many people they will have to feed, and, in some cases, accommodate. What is at stake is the mana of the host tribes or tangata whenua and their display of manaakitanga. Manaakitanga is the critical measure of success. The study found that evidence of this organising capacity transferred into Māori leadership practice in public-sector environments. What this shows is that the principles that apply in the Māori world, such as manaakitanga, along with the associated cultural, organisational, and planning practices, transition into leadership practices within the public sector as Māori seek to fulfil expectations and cultural obligations to build and sustain relationships.

Whaikōrero is one example of a traditional Māori leadership practice that is used in different government agency situations, such as to welcome or greet people. Rewi (2010) explored in depth discourse among Māori scholars and practitioners to identify its origins and essences, and his unsurprising finding was that it was difficult to explain: 'whaikōrero just is'. Rewi remarks: 
the boundaries of this belief system span from one horizon to the next, and its philosophies originate from the beginning of time with links to the present, and encompass the Mãori and non-Māori worlds and the evolution that continues to take place within, between and around them (p.10).

And so it is with Māori L-A-P: as a holistic phenomenon, it just is. It is difficult to identify Māori leadership as an entity unto itself, and hard to explain it. L-A-P gives Māori cultural elements such as whāikōrero a level of tangibility. In the Māori world, the dynamics and organising processes for common Māori elements visible in public administration, such as whaikōrero, hui, and pōwhiri, mean that Māori practices must follow general rules and protocols (tikanga and kawa).

Māori leadership is an everyday thing. Practice involves inter-weaving social interaction, providing direction for organising processes, and re-orienting the flow of practice through collaborative agency (Crevani \& Endrissat, 2010). The process by which practice happens within the context of a government agency depends on a range of factors and decisions within the agency. It may be determined by the purpose of the occasion, whether ministers or other dignitaries are involved, visitors, the relationship with mana whenua (local people of the land), and the skills and capacity of the agency to undertake the formalities. What occurs beneath the surface is the ebb and flow and dynamics of human behaviour, how things happen, how decisions are made, and what trade-offs and considerations are made.

\section{Chapter Summary}

This chapter examined the voices of lived experience and the NZQA case study and presented key findings, themes, and kaupapa Māori perspectives. The chapter finds Māori dimensions to Raelin's (2016) praxis view, which privileges the essential cultural and political rudiments that influence how leadership occurs. The analysis identifies two key patterns: first, living proof that there is a momentum towards L-A-P as an appropriate alternative to Māori leadership as the glorification of individual leaders, and secondly, evidence of a shift that validates Māori L-A-P as a collective and strategic mode of publicsector leadership that balances the competing demands of rangatiratanga and 
kāwanatanga. This subtle shift re-positions kaupapa Māori from a view of looking inside an organisation to identify a show of diversity towards identifying greater inclusion of kaupapa and mātauranga Māori elements embedded within the hearts, minds, systems, and processes of organisations.

Stepping back to view the takapau wharanui, the inter-relationships between theoretical concepts and practice, identified that Māori leadership practices are holistic and dynamic. Māori commonly say, 'there is a tikanga for everything', and the takapau wharanui reflects this point. The narrative is quite different to the traditional model, and requires new levels of sophistication in partaking of knowledge and sharing communication. In a modern world, the capacity to move comfortably, confidently, and respectfully requires a leadership capability with broader and deeper levels of understanding and more clarity of the two-worlds interface than has been expected before.

As I interviewed participants, their voices became animated when they reflected upon where it all started for them and how they got to be where they are today. Career reflections provided an insight into the contexts and situations within which Māori public servants had to operate and how they needed to be as Māori public servants. Participants recognised that leadership practice in public administration has matured, and that has helped to reduce the negative stigma attached to Māori working in government agencies. Participants were pleased the model has moved from the Māori office or Māori unit being the lone ranger to a model whereby 'no longer is one agency accountable for Māori outcomes, everyone is'.

The context of kāwanatanga is the ultimate challenge for Māori leadership practice. The evidence resounded that forces entrenched in colonial tradition 'smash up' against kaupapa Māori philosophies and practices. Māori officials withstand pressure and attack from within kāwanatanga and face the same intense scrutiny, resistance, and ridicule from Māori. Examining experiences identified that Māori public servants found themselves at a crossroads, some opting out of public service, others committing themselves to 'being that difference'. In many ways, a modern era of Māori leadership practice in public administration has arrived. Māori officials who are confident about their place in the public sector are no longer unsure of who they are accountable to; they 
have already crossed that bridge. The new leadership practice model is disciplined, educated, and courageous, and with a sense of drive and purpose. There is added value; they are Māori. Yet only Māori understand this extra value, and it does not fit the public service image of what public-sector looks like. There are still mountains to climb. 


\section{Chapter Seven: Manurau: Developing a Conceptual Framework of Māori Leadership}

\section{Overview}

As I did with the previous chapter, I begin this chapter by anchoring the proposed framework within a whakapapa base, in my case Te Arawa whakapapa, as the starting point to secure the Māori perspective of leadership. My Te Arawa whakapapa, through ancestors such as Tūhourangi, Wahiao, Whakaue, and Tapuika, allows me to honour my great-grandmother, Manurau. As outlined in Chapter One, in the section Te Arawa e, my great-grandmother Manurau was named after her great-grandmother Manurau (1). Manurau (1) married Kotua. Kotua begat Parata. Parata begat Porokaiwhiria, who begat Manurau (2), my great-grandmother. Manurau (1) composed a waiata moteatea (song of lament) called 'Kotua Ake'. It was a love song for her husband Kotua, who was killed by Ngā Puhi on a back road to Tauranga. He had sacrificed himself to save the hapū that were with him. Traditionally that track was for peaceful pursuits such as food-gathering (P. Renati, personal communication, 21 October, 2017). This whakapapa kōrero is remembered today through waiata moteatea.

In 1905, my great-grandmother Manurau (2) married Renati Mita-Maika at Te Papaiouru marae, Ohinemutu. My whānau whakapapa descends from Wi Keepa Te Rangipuawhe, who married Ruiha and begat Te Uruhi Mita Maika Te Rangipuawhe. Both were chiefs of Tūhourangi in their time. Te Uruhi married Te Hiahianui Akuhata Te Amohau of Ngāti Whakaue and begat Renati. Renati is the grandson of Wi Keepa. This overview is important, to establish the importance of whakapapa and Māori tribal tradition to Māori leadership and to connect the relevance of this research to whakapapa and leadership. With the blessing of my whānau and the descendants of Renati Maika Te Rangipuawhe and Manurau Wepiha, and the iwi of Tūhourangi, Tapuika-Ngāti Moko, and Ngāti Whakaue, I have chosen Manurau as the name of this thesis and framework.

Manurau is important from the perspective of whanaungatanga. The whānau understand Manurau to be a woman of high standing, with fiery red hair. She possessed an inner strength and determination. She was a princess (M. Te Amo, personal communication, 12 March, 2018). Whānau kōrero re-tells how life was for Manurau, and at times it was not 
all pleasant. In hard times, she returned from Rotorua to Waitangi, Te Puke, and sought wellbeing and good health from the place of her upbringing, among her whānau at Ngāti Moko. This may go some way to explain why Renati left his chiefly responsibilities at Whakarewarewa to be with Manurau at Waitangi.

The notion of Manurau links the elements of leadership to the concept of whakapapa kōrero through storytelling and narrative, enabling the capacity to engage with others and practice leadership. At all times, this is underpinned by the cultural and spiritual elements within tikanga Māori. The notion of Manurau links to collaborative aspects of leadership and the relational elements of unifying and supporting people around a common purpose. Furthermore, Manurau links the strategic and visioning aspects of leadership to the notion of whakaaro rangatira, a capacity of thought leadership. The significance of Manurau to Māori leadership practice is its collective endeavour, and this is explained through its literal meaning.

Manu means bird. Rau has several meanings. The relevant meaning for this study is 'hundred' or 'multitude'. I have therefore taken the literal meaning as 'a hundred birds' or 'a multitude of birds'. I visualise Manurau as a multitude of birds soaring across the oceans and land with an over-arching vision of the relevant landscapes and terrains offering ideas and visions that extend beyond the horizons of time and space. Manurau lessens the dependence on an individual manu operating as a leader, but rather validates Māori leadership as a collective of manu navigating the space and creating patterns, by recalling stories of past achievement and setting the path for future directions.

\section{Introduction}

This chapter presents a discussion about Manurau as a range of theoretical ideas and Māori methodologies which draws on both the theoretical work and empirical findings presented in the study thus far. It is best to describe the offerings of Manurau as elements that public servants and agencies can use and/or adapt to suit their individual or collective leadership purposes. It enables public servant leaders, both Māori and nonMāori, to fill their kete with ideas and concepts for leadership development, life-long learning, and progression, and to develop critical practices by being alert to te ao Māori. 
The research has found that the core thread of Māori leadership-as-practice (L-A-P) is to accentuate the Māori voice within kāwanatanga spaces. The relevance of Manurau is to validate Māori ways of seeing, knowing, and doing in the public sector, and to proclaim Māori L-A-P. A theoretical framework provides a culturally safe place to acknowledge and recognise principles and practices so agencies can understand the relationships with the Māori world. The discussion about developing a theoretical framework proposes that the connection between mātauranga Māori, with all its dynamic capacities and potential, and the context of kāwanatanga creates space that calls for a specific set of values and principles necessary for leadership in the public sector.

\section{Where Have we Got to?}

The research thus far has traversed the experiences and voices of Māori officials walking in two worlds. We have found that the parameters for Māori L-A-P are grounded in the reality of mātauranga Māori inviting essential Māori philosophical, spiritual, and cultural world views. Māori in the public sector encounter kāwanatanga contexts absorbed within debates about the place of the Treaty of Waitangi, issues of institutional racism and bias, and persistent socio-economic disparity for Māori. We have found that despite the tension and contradictions there is positivity, growing awareness, and a modern postTreaty of Waitangi settlement context that is filled with hope and Māori aspiration.

The story thus far tells us Māori leadership is emerging as a practice specialisation that requires an understanding of Māori knowledge content (mātauranga Māori) and the environmental context inside kāwanatanga. The underpinning theory is Māori, kaupapa Māori, based on Māori ways of knowing, seeing, and doing (Smith, 1997). Research participants give us an insight into what good and bad looks like in Māori leadership through their understanding of how the myriad of concepts inter-connects and how they are intuitively able to conceive of and enact appropriate leadership that is underpinned by a kaupapa and tikanga practice.

My reflections of the analysis point to a theory of Māori leadership that must be adaptable to the context of the modern and global world, with changing demographic profiles, technological disruption, and socio-cultural expectations. The nature of Māori leadership 
as it unfolds in the Māori world is mirrored in the public sector by its dynamism, holism, and fluidity. How it is organised and operated depends on the propensity and collective capacity of people and the various situation or issues at hand. Undeniably, however, the context demands a practice specialisation, with Māori philosophy underpinning distinctive principles and leadership practices.

There are implications for the public sector that surface in the discussion about diversity, inclusion, equity, and leadership development in the public sector. Participants questioned how Māori leadership capabilities and specialisms are recognised and validated. How are development plans for Māori officials considered, and how do Māori officials graduate to senior roles in government agencies? The major concern is the lack of recognition for kaupapa and mātauranga Māori and Māori public servant aspirations, implying the public sector does not understand Māori elements well enough to attract, recruit, retain, and develop Māori leadership and Māori L-A-P.

\section{Manurau: Objectives}

There are two main objectives for Manurau. The first is to evidence Māori leadership as a collective praxis, as opposed to descriptions of individual leader talents within the field of public administration. The second is to describe a conceptual framework for the public sector, validating Māori leadership concepts, that may sit comfortably alongside other leadership frameworks. Agencies and public-sector leaders may utilise Manurau to:

- build confidence, courage, and resilience operating in two-world spaces

- support Māori public servant development, recruitment, and progression

- safeguard and protect others in the transmission of Māori knowledge

- $\quad$ ensure Māori leadership knowledge contributes to better leadership

- validate Māori leadership practice specialisations

- help agencies to understand how they may improve relationships with Māori

- provide information on how to support Māori staff

- inform the public sector about how leadership development programmes can incorporate Māori leadership concepts

- communicate, unite and care for the people. 
The theoretical construction of Manurau is now explained by placing three layers of analysis over the takapau wharanui, the great mat.

\section{The First Layer: Whakaaro Rangatira}

The thesis now reflects upon a local tribal story to explore the concept of whakaaro rangatira. There is very little literature that discusses the concept of whakaaro rangatira as a theoretical element. The best way to describe whakaaro rangatira is 'a chiefly thought' or 'thought leadership'. Whakaaro means 'to think; an idea; to understand, decide, or plan'. We know rangatira means 'chief' or 'to weave the people together'. We now explore how the concept of whakaaro rangatira is a unique aspect of Māori leadership practice.

In 2015, Clandon Park House, located at the Clandon Park in Surrey, was completely gutted by fire. Clandon Park is the home of the ancestress tupuna whare Hinemihi, of Ngāti Hinemihi, Tūhourangi, carved by Tene Waitere and Wero Taroi from Ngāti Tarawhai. After the Tarawera eruption in 1886, the whare Hinemihi was purchased by William Onslow, Earl of Onslow for fifty pounds from Mika Aporo. Lord Onslow located Hinemihi at Clandon Park, where she has stood for over 100 years.

My relationship to Hinemihi is not directly to Hinemihi, but it is through my Tūhourangi whakapapa to Wi Keepa Te Rangipuawhe, who was the tribal leader at the time of the Tarawera eruption. Wi Keepa lived at Te Wairoa, southwest of Rotorua, and Hinemihi, also located at Te Wairoa, sheltered the Tūhourangi survivors. When I heard of the fire at Clandon Park I rang my uncle Tony to let him know what had occurred. We talked, and we thought the best thing to do was for Tūhourangi to travel to Clandon Park to visit Clandon Park House and the British National Trust. The purpose of the visit would be to convey our condolences and sympathies for the loss of Clandon Park House. Clandon Park House had sat alongside Hinemihi for over 100 years. She was like her adopted mother, and had watched over her. The significance of the loss of Clandon Park House on Hinemihi, as Hinemihi's loss, was felt. The idea was to 'tuku aroha' - a practice of sharing our thoughts of love, respect, and compassion for their loss. My uncle Tony said to me 'He 
whakaaro rangatira tēnā', meaning 'That is a chiefly thought', or, in terms relevant to this study, 'That is thought leadership'.

My interpretation of whakaaro rangatira is a philosophy of thought leadership through lived experience. It is a way of thinking that connects choices and decisions to how you think the old people might have experienced and thought about issues. I draw on whakapapa and tikanga Māori, and the aim is to be consistent with tribal learning and tribal ways of doing things. There is wisdom associated with the notion of whakaaro rangatira. It is guided by tikanga and kawa, but most importantly it is guided by common sense. The example of 'tuku aroha' is a simple practice to show love, respect, and compassion, a human practice based on human principles.

The tribal story reinforces the research findings that mātauranga Māori fundamentally differentiates Māori leadership from Western forms of leadership. It is accurate to describe thinking from the Mãori perspective as privileging belief systems found in the 'collective and intergenerational wisdom embodied by te ao Māori' (Henry \& Pene, 2001, p. 235).

Thinking is connected to the journeys traversed by our tūpuna and the inter-generational transmission of knowledge and practices such as tuku aroha that enable us to be here sustain Māori practices. Whakaaro rangatira is the method of Māori ways of knowing, through storytelling and whakataukī. Whakataukī is an outward expression of mātauranga Māori that gives us clues as to how the old people viewed the world (Mead, 2003). Whakataukī have found ways into public administration, along with bilingual names for agencies, common greetings, signatures in te reo Māori, and other modern design artefacts, including taonga and artworks. Whakataukī have been useful in helping public servants learn te reo Māori and connect key messages within whakataukī to a particular agenda or purpose.

The visibility of whakataukī in public administration indicates there is a place for Māori ways of thinking in the public sector. Therefore, the first layer of the framework places whakataukī as the foundation. This layer acknowledges the philosophical stance that two worlds come together and create a specific context for L-A-P, cognisant of the historical, 
social, political, economic, and technological givens (Crosby \& Bryson, 2005). The thesis argues that despite contemporary ideas about Māori leadership, traditional Māori knowledge (ways of knowing and thinking) and wisdom are the embedded factor that distinguishes Māori leadership from other forms of leadership.

The methodology of whakataukī ensures continuity of wisdom and storytelling in the inter-generational transmission of Māori leadership knowledge and Māori leadership development. Whakataukī can be interpreted in different ways. However, expanding on the concept of whakaaro rangatira and the use of whakataukī as key tools of Māori thought leadership, the thesis now explores three specific whakatauki connecting the metaphors of rangatira (as leaders), manu (as knowledge holders), and tangata (as people) to lay the foundation platform to consider Māori leadership concepts from an authentic Māori base. These three proverbs are well known in the Māori world.

They are:

Ko te kai a te rangatira he kōrero, ko te tohu o te rangatira, he manaaki ko te mahi a te rangatira hei whakatira i te iwi.

(The food of chief is talk

The sign of the chief is generosity The work of the chief is to unite the people)

This refers to the communication of knowledge, education, and voice; the mark of leadership is care, hospitality, and reciprocity; the purpose is to unite the people.

Te manu ka kai i te miro nōna te ngāhere

Te manu ka kai i te mātauranga nōna te ao

(The bird that partakes of the berry his/hers is the forest The bird that partakes of knowledge his/hers is the world)

This refers to the legitimacy of Māori epistemologies as a basis to sustain people and communities.

He aha te mea nui o te ao, he tangata, he tangata, he tangata

(What is the most important things in the world, it is people, it is people, it is people). 
This refers to the wellbeing of people as the most important thing in Māori leadership practice.
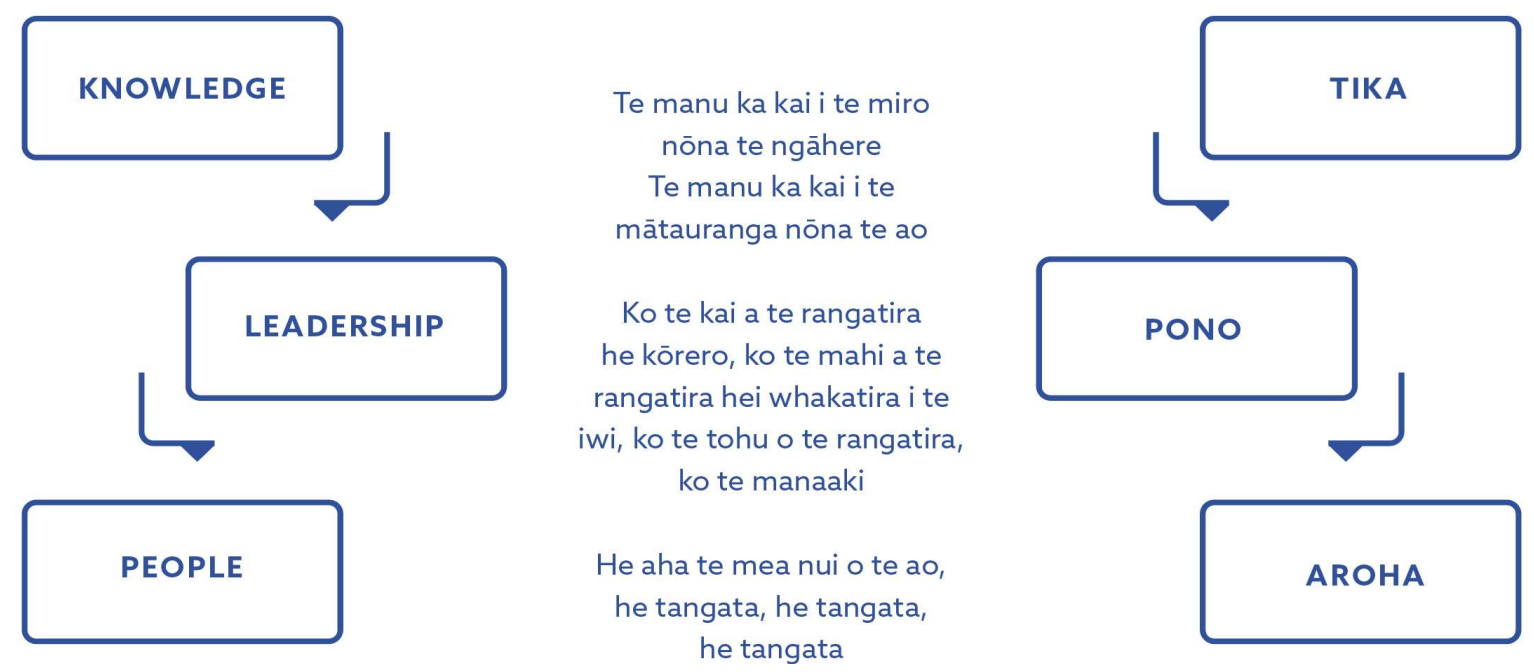

Figure 4: The whakatauki-based concept of whakaaro rangatira

Manurau is conceptualised in a way that is appropriate for the public sector. It is based on whakataukī, and is visualised as the inter-weaving of knowledge, leadership, and people, enveloped within spiritual and human dimensions, emphasized by the voices of lived experience, of tika (truth), pono (honesty), and aroha (love).

Te Kai a te Rangatira he Kōrero

Ko te kai a te rangatira he kōrero, Ko te tohu o te rangatira, he manaaki Ko te mahi a te rangatira hei whakatira i te iwi.

The literature on Māori leadership accepts the whakataukī 'Ko te kai a te rangatira ko te kōrero' as a definitive statement of Māori leadership (Diamond, 2003; Katene, 2013). Bishop Manuhuia Bennett, as quoted by Winiata (2001), addresses the issue that the concept of 'leader' is limited and that this whakataukī recognises the attributes of 'rangatira' (p.12). Kōrero, translated as 'talk', is a central pillar of Māori society. Talk is 
linked with the transmission of knowledge and with the establishment of identity and a place to stand (Ihimaera et al., 1993; Walker, 1993 in Tipene-Matua, Phillips, Cram, Parsons, \& Taupo, 2009). The whakataukī provides a leadership model to guide all Māori in whatever context or situation you find yourself in, including for Māori working outside the traditional Māori context, such as within kāwanatanga.

During my time working at the NZQA I have had the opportunity to listen to and engage with pre-eminent Māori scholars, educationalists, and tribal leaders. Collectively, we have produced publications, presentations, statements, and video clips as tools to spread the message about mātauranga Māori and key conceptual ideas about the notion of mātauranga Māori in education and qualifications. As an everyday practice, there is undoubted support for the notion of kōrero as a practice of sharing knowledge; this is referred to as 'the food of chiefs'. Through kōrero we can share ideas and thoughts, and the presentation and articulation of kōrero, using whakapapa, landscapes, events, and achievements, give substance and meaning to the message.

Analysis of this whakataukī considers the words and phrases, specifically the verbs or action words. For example, 'kōrero' simply translates to talk. The food of a chief is talk. What this emphasises is that L-A-P is about the fostering of ongoing communication, discussion, and knowledge. The phrase 'whakatira i te iwi' translates to 'to unite the people' and emphasises that L-A-P is about work to bring people together, to form a mutual understanding, to weave people and ideas together. The phrase 'ko te tohu o te rangatira he manaaki' ('the sign of a chief is looking after people') encompasses multiple elements of care, reciprocity, and hospitality within L-A-P. These practices have been handed down through the generations by tupuna. They are captured in traditional knowledge forms and articulated in a wide range of ways, including whakataukī and waiata.

Within the word rangatira, the 'ranga' or 'weaving' element is a constant practice weaving Māori and non-Māori people together, including their thoughts and mindsets (Spiller et al., 2010). The practice involves dispelling myths, sharing realities, forming ideas, connecting with people's hearts, and taking action together in a way that is respectful to te ao Māori. It follows tikanga Māori, a way of doing things that is learned through understanding what is right and wrong. Everything has a tikanga, and the 
expression of rangatiratanga is no different (Mead, 2003).

Research participants consistently referred to Māori leadership as an innate and intuitive strength. As this study has identified, Māori public servants bring their deliberate acts of leadership forward through their personal understanding of kaupapa, Māori ways of knowing, and whakapapa; who they are, their upbringing, and how they connect to others and the environment. It is realised in practice by 'weaving expressions'; how they bring people together, the way they welcome people, the way they invite new ideas, the way they summarise discussions, the way they care for the people, but also the way they interject, make tough decisions, and take action. The leadership they bring to an environment is empathy, care, relationships, understanding, knowledge, influence, and voice.

Weaving dimensions are identified that reflect a Māori way of leading that relates to the way concepts of leadership are constructed as personal leadership (Schaetti, Ramsey, \& Watanabe, 2008), ancestral leadership (Kelly et al., 2014), and authentic leadership (Avolio \& Gardner, 2005). This is best exemplified throughout the case narratives which show Māori public servants leading in a way that ensures the mana of all parties involved is kept intact, and leading in a way that demonstrates humility. The insights of lived experience show how these dimensions emerge as great strengths, rather than being perceived as weaknesses of shyness, not speaking up, and being too passive.

\section{Mātauranga te Kai i te Ao i te Po}

\section{Te manu ka kai i te miro nōna te ngāhere}

\section{Te manu ka kai i te mātauranga nōna te ao}

The phrase 'Mātauranga te kai i te ao i te po' (knowledge is the food, by day and by night) emerged from the study to emphasise the totality and timelessness of Māori epistemology that links people to past, present, and future worlds, including other realms, and in any context including kāwanatanga. The 'Mātauranga te kai i te ao i te po' space includes elements that create the innateness of Māori leadership that participants found hard to explain, as a natural, spiritual, and emotive experience that is underpinned by the Māori concepts of: 
- mana - prestige, authority, control, power, respect

- tapu - sacredness

- wehi - awesomeness

- ihi - power

- wairua - spirituality

- mauri - life force.

Henare \& Pene (2001) describes Māori world views as embodying principles of 'tapu', 'mana', 'mauri', and 'hau' that, according to Māori scholars such as Marsden (2003) embody te ao Māori, the Māori world, which is inter-connected physically, spiritually, and philosophically. These values form traditional Māori ontology and assumptions about what is real (Henry \& Pene, 2001). Ruwhiu and Elkin (2016) conceptualised elements of servant leadership with indigenous Māori leadership, linking ethical and collective morality with human relationships and context-specificity (p. 308). This provides a perspective that servant leadership values and Māori values are consistent and supports the notion of public service as serving the people and making a difference.

Ruwhiu and Cone (2013) explored the notion of Māori leadership 'as a form of pragmatic leadership' and highlighted how Māori leadership practice is 'relational and value rational, embedded within the innate connectedness of human beings and spirit'. This extended their description of a process of 'socialized experiences', which instils an innate sense of a special approach to leadership and embedded relations (Ruwhiu \& Cone, 2013). Again, the scholarship considers the notions of whānau and whanaungatanga, as identified in the study, to be fundamental to the experience of Māori leadership.

Professor Taiarahia Black, who worked closely with the NZQA as a member of Ngā Kaitūhono, felt that Ngā Kaitūhono needed to take responsibility for conversations about mātauranga Māori. Taiarahia Black wrote in the publication Enhancing Mātauranga Mãori and Global Indigenous Knowledge (Black, 2014) that mātauranga Māori elevates the idea of Māori leadership and relates it to the significance of the toroa (albatross - one of the largest flying seabirds) as the representation of magnificence, authority, and expression. Black makes reference to 'aho ariki' (prestigious lineage), which has a symbolic place in the sources of Māori knowledge and builds the connections and sharing 
of multi-layered engagement (p. 5). Black suggests the Māori world view of leadership in the context of the public sector is guided by the elements of continuity, change, connections, unity, and relationships.

Using the analogy of Manurau, I metaphorically refer to a public servant as a manu (a bird). Observing Māori L-A-P in government agencies is analogous to observing many manu working and travelling in a common direction. Whilst there are many views, values, and missions expressed within the collective, it is clear they are each connected to mutual goals and outcomes for Māori and a commitment to the Treaty of Waitangi. At times, manu sit on waka (work in organisations) that align with their aspirations; sometimes, they fly off the waka. Sometimes they are shoo-ed off the waka. Sometimes other manu, like the toroa (the albatross), join them on the waka and become beacons for transformation and change. There is not one source of sustenance; there are many. There is not one pathway; there are many. As the seasons change and migration patterns are disrupted, or manu die, birds seek solace in their ngahere (in their respective whānau, hapū, iwi, and communities) to revitalise and reconnect their aspirations and priorities to the greater good.

The decision to use this whakataukī as the basis for the framework is based on the NZQA experience with mātauranga Māori. The NZQA experience identified whakataukī as the inspiration that influenced the NZQA's values system. The first line of the whakataukī says 'the bird who partakes of the berry - his or hers is the forest'. The berry is a metaphor for nourishment and sustenance. The forest is a metaphor for family or community. The miro, the berry, is vital to this argument. The makings of the miro berry include culture, identity, and language: the things that provide a sense of knowing who you are, where you come from, and where your place is in the world. The logic is that by partaking of the miro berry you will find a firm understanding of your identity (tuakiritanga), language (te reo Māori), and culture (tikanga), and a place to stand (tūrangawaewae). It provides the spiritual (wairuatanga) strength and resilience necessary for leadership. Partaking of the miro berry provides a clear sense of purpose to contribute to the wellbeing of the family and community. 
The second line is 'the bird who partakes of knowledge - his or hers is the world'. The word 'knowledge' in this proverb refers to new ways of knowing, and using Apirana Ngata's words, the modern tools of the world. Mātauranga is a relatively new and modern word for Māori knowledge. Partaking of Māori knowledge enables a person to explore new tools, processes, data, and languages to create new knowledge and potential, as promoted by Charles Royal (NZQA, 2009), and to participate in the global word (Durie, 2003).

The conceptual idea focuses on the miro (deep Māori knowledge) and mātauranga (broad knowledge), and the purpose of the whakatauki is to say in a leadership environment and context that both the miro and mātauranga are equal and relevant. One does not dominate or compromise the other; both are valid, and both are legitimate sources of sustenance and can work together within a context of leadership and service to contribute to the community and to contribute to the global world.

He Aha te Mea Nui o te Ao?

Hūtia te rito, hūtia te rito o te harakeke

Kei hea te kōmako e kō?

Kī mai ki ahau he aha te mea nui o te ao?

Māku e kī atu

He tangata, he tangata, he tangata .

(If you remove the heart of the flax bush

From where will the bellbird sing?

If you say to me, 'What is the most important thing in the world?'

I will reply,

'It is people, it is people, it is people').

This whakatauki is well known throughout New Zealand and is heard on many marae and at many hui. Government agencies refer to this whakataukī in speeches and documents and it is met with total agreement. I have heard no one argue against the fact that the whakataukī is wise counsel from our ancestors and is particularly appropriate when there are major problems and issues and decision-makers are seeking answers. The 
research participants raised this whakataukī and emphasised its importance in many situations (such as public safety, child welfare, or student success) and in many organisational settings. Crosby and Bryson (2005) identified that the starting point for understanding your call to leadership is to understand the context for leadership by putting the question, 'What do I deeply care about?' This question is simply answered by Māori through this whakataukī.

The question 'What do I care deeply about?' can also be asked another way; that is, 'What truly matters to me?' Sir Mason Durie identified that what truly matters is to make a difference to the lives of whānau so they may be independent and live and succeed as Māori (Durie, 2003). Immediately a connection is drawn between the voices articulating their commitment and role to make a difference for Māori and expressions of whanaungatanga and manaakitanga within that process. Māori align their personal philosophical disposition and privileged position to not only address historical injustices and inequities that persist within the government system, but also navigate the process to ensure whānau and people are cared for. The case studies and interviews gave evidence of Māori officials deliberately choosing to work with whānau so they could make a difference to peoples' lives.

Integrating the three underpinning concepts of weaving of rangatira, mātauranga, and manu (metaphorically as people) provides a foundational layer to understand the specialised field of Māori leadership that is appropriate for a context such as kāwanatanga.

\section{The Second Layer: Whakapapa Kōrero}

The next section builds upon the whakataukì-inspired theoretical perspective of Māori leadership practice and now presents three critical elements of whakapapa kōrero as the second layer. These are:

- tū rangatira - seeing through Mãori eyes

- whakarongo ake au - listening with Māori ears

- ngākau Māori - feeling with a Māori heart. 
'The system still has work to do to ensure new generations of leaders can build upon, and not destroy the legacies of past leaders'. (Research participant)

Legacies and Māori narratives expose the hurt and the denial of access to power and equity Māori have faced resulting from colonisation. Participants remarked that in a modern world, we benefit from understanding the challenges past leaders faced. What is most important is to understand why and how past leadership occurred and under what circumstances those practices were viewed as exceptional so we may benefit from that lived experience. Participants were avid in their recollection of identities, events, and decisions whilst sharing their story of their experience. Communication of whakapapa kōrero gives full expression of the legitimacy of the Māori view of the experience. It helps people to visualise, hear, and feel the essence of the kōrero and inter-relationships.

In a traditional context, whakapapa kōrero is the communication of whakapapa knowledge, encapsulated within Māori episteme, and is an active process of reproducing and sharing and transferring knowledge. Edwards (2009) strongly argues whakapapa is a methodological tool for understanding and engaging with discussions of Māori, including rangahau (research), and I would add policy and organisational development.

Edwards uses the notion of voyaging as a metaphor for whakapapa kōrero methodology, and this links nicely with the concept of Māori public servants navigating spaces and embarking upon new journeys from the centrality of whānau and community life into the construction of bureaucracy. Spiller and others use the voyaging, wayfinding, and navigational metaphors as a powerful way to re-imagine the journeys of our ancestors and to suggest that the capacities to embark on such ventures are inherent in the whakapapa and DNA of current and future generations of Māori. It is the tool to rationalise thought and practice (p. 43).

Smith (2000) states that whakapapa kōrero is discourse held by tangata whenua as important narratives that define their identity. As taonga they also represent a knowledge base for the survival and welfare of the group. According to Smith, whakapapa kōrero rationalises existence through inter-connectedness and relationships. It provides a communication tool and practice for linking the past, present, and future and enables 
leadership conversations about new potential and pathways to occur (Edwards, 2009, pp. 44-46). What modern-day Māori scholars have rightly identified, and what is consistent within this research, is the power of the Māori narrative and organisational memory as portals of knowledge for intergenerational transmission and presentation.

The long-standing view of traditional Māori scholars such as Maharaia Winiata (1967) depicted the Māori public servant leader as little more than 'the agent of change par excellence' to represent the European to the Māori, and 'only incidentally does he become the mouthpiece of the Māori to the European' (Katene, 2013, p. 174). The analysis in Chapter Six recognised a change in relationship pattern between Māori officials and their cognisance of the impact of changes in policy, relationships, and decisions. The cases in this thesis highlight the relevance of whakapapa kōrero as Māori methodology to rationalise goals, purposes, actions, and decisions. The wānanga and research interviews with NZQA staff repeated conversations that occurred about the role and status of Dr Monte Ohia, as the senior NZQA Māori official, and of whakaruruhau, and the concerns that Māori had about their Māori knowledge within the qualifications system. They remind us to reflect on those stories so we may forge a future that does not take Māori backwards.

The fact that the relationship between the NZQA and mātauranga Māori elevated the conversation of Māori knowledge followed the pathway set out by Durie (2003) for Māori 'to live as Māori, to be healthy, educated and global citizens of the world'. Whakapapa kōrero helped the flow of conversation among tribal rangatira, scholars, Māori officials, and community-based practitioners. It fostered relationships and integrated multiple perspectives whereby deeper and more meaningful conversations about mātauranga Māori enabled an intellectual exchange, a Māori rationale, and models to advance thinking about mātauranga Māori (NZQA, 2007). This engaged Māori (rangatiratanga) and a Crown agency (kāwanatanga) in Māori methodologies and demonstrated L-A-P.

What emerged strongly was the inherent nature and capacity to practice leadership, as Māori, in a way that is positive and enduring. Practices identified throughout the research have been performed consistently over a long period of time. Each of the ideas is congruent with the concepts raised about thinking from a Māori world view - seeing with 
Māori eyes, listening with Māori ears, feeling with a Māori heart - and fashions the methodological models and focus areas for L-A-P capabilities unique to Māori.

Recalling the relationship between people, events, and outcomes from a Māori perspective engenders a Māori voice and spirit. It creates an environment where every engagement with Māori is a positive one. Notably, research participants reflected that Māori in the public service today are less fluent in the ways of the old people, and do not have the life experience in the way the old Māori people did. Whilst they might be better educated in the Pākehā sense - better qualified, more worldly, more technologically capable - there was a significant void in mātauranga Māori knowledge. Learned Māori knowledge through education pathways was more prevalent, rather than lived knowledge, of the type previous generations had. There was a feeling of sadness that this knowledge has been lost. Yet despite this, learned Māori knowledge and history were highly valued among participants, and provided windows into the wisdom of the old people. There is a development opportunity beckoning.

\section{Tū Rangatira - Stance to see Through Mãori eyes}

As Māori you bring something different, you understand the DNA of the nation and lead conversations, you can translate into something quite practical. (Research Participant)

Tū rangatira is a stance that enables public servants to see with Māori eyes, to better understand the dynamics and intricacies of Māori needs, ways, and aspirations. 'Tū' means 'to stand' and 'rangatira' means 'chief' or 'chiefly', and 'weaving the people together'. Tū is also short for Tūmatauenga, the atua or god of war, as understood within Māori epistemology. Hence, this statement is interpreted as a 'Māori chiefly stance'. The argument follows that L-A-P in Māori terms refers to the positions public servants take to hold firm and advance kaupapa Māori by seeing and working through kaupapa Māori, 'seeing through Māori eyes'.

Tū rangatira methodologies draw on elements of tikanga Māori, whakapapa kōrero, and manaakitanga to ensure Māori goals and aspirations are advanced and articulated appropriately. The tū rangatira stance implies a position that is 'strategic all of the time'. 
It involves strategic conversations with collectives of people, building relationships, common understandings, and appropriate use of tikanga Māori and protocols for engagement. The research showed that Māori leadership practitioners flourish in leadership environments where there are issues at the interface that require the Māori leader to weave the people together, lead and summarise conversations, and present the opportunities and challenges ahead.

In public administration, the tū rangatira stance applies to adapting to and managing change. This involves thinking, as Māori, about how the organisational culture and leadership mindset can enable better policy and management decision-making. There is a clear relationship between entrepreneurship/intrapreneurship, innovation and change, and Māori leadership. Migration journeys over oceans to Aotearoa, and Ihenga's exploratory travels all point to a fact of whakapapa, or DNA, that inspires Māori to be curious and practical. The case studies and interviews identified a high level of expectation for Māori leadership to create space within government organisations for innovation, creativity, and disruption. This was viewed a positive by participants, who said 'we have to learn from mistakes and find new ways'.

The study tells us that Māori public servants want to make a difference for whānau, and other New Zealanders too, as opposed to getting caught in the machinations of government bureaucracy and iwi dynamics. Māori choose to be working for the government to be that difference. Career decisions, professional interests, and choices as to how to invest their time are a function of wanting to contribute to better outcomes for Māori. Whether the kaupapa is education, policing, child welfare, or te reo Māori, Māori public servants pursue kaupapa Māori agendas, and as a public servant this deep personal motivation is reflected in people's work, aspirations, career ambitions, and personal commitment. Māori public servants make decisions based upon what they see, what feels right, and where they can add most value.

In this study, I became curious about the situations Māori officials find themselves in, and because they are Māori why they lead the way they do. My experience and observations identified situations and environments that cause Māori public servants to struggle; for example: 
- managers not supporting kaupapa Māori ideas

- frustration during pōwhiri in government agencies as tikanga practices are conducted poorly

- being challenged by other Māori questioning how Māori they are

- maintaining calmness during verbal attacks by Māori on a government agency or officials

- physically protecting a minister of the Crown from Māori protestors.

Despite the challenges, complexities, and biases that working in the two-worlds context presents, personal reflections and participants' voices confirm this deep sense of tū rangatira - seeing through Māori eyes - as the key to overcome the day-to-day challenges and compromises, and to make a difference for their organisations and the communities they serve.

Whakarongo Ake Au - Listening with Māori ears

Whakarongo ake au ki te tangi a te manu tui tui tui tuia tuia kei runga, tuia kei raro, tuia kei roto, tuia kei waho tuia te here tangata ka rongo te pō ka rongo te ao, ka rongo hoki te kāwai tangata i heke mai i Hawaiki nui, Hawaiki roa, Hawaiki pāmamao, ki te whaiao, ki te ao mārama, tihei mauri ora

'Whakarongo' means 'to listen'. 'Ki te tangi' ('to the cries'), 'ma tui' ('of the tui bird'), 'tui tuia' (that are sewn together as a collective voice). Whakarongo ki te tangi a te manu reminds us that we are connected to a wider world. We are not isolated from our natural environment; instead there are enduring bonds between land, people, and sky (Durie, 2011). This opening statement encapsulates a desire for the context of the Māori world; that is, the enduring bonds, to be heard in the spirit within which the messages and voices of Māori are conveyed. This concept is realised by leadership practice that is necessary for Crown-Māori engagement. 
The first point is to listen. The practice of listening is a critical skill that means to be cognisant of the flow of the kōrero (to whai - follow - the kōrero - discussion). The way to undertake listening as a practice is to be aware that expressions and voices of Māori articulate an issue within a wider context of socio-cultural, whānau, environmental, and economic reality. The issue or kaupapa has a whakapapa - a history and legacy associated with it. History reflects a narrative of Crown-Māori relationships that has created kāwanatanga context connected to failure, disparity, and dysfunction. Listen to the cries of the tūi bird, as they have a story to tell.

Participants stated that Māori officials provide a window to the Māori perspective. They provide access to Māori knowledge and contribute to public sector leadership environments because they listen and have an innate understanding of the various dimensions and issues. Lived experience of dealing with bias, inequity, and barriers means Māori officials understand the Māori view and can be both empathetic and pragmatic. The analysis identified listening as critical leadership practice that is particularly pertinent in Māori contexts.

\section{Ngākau Māori - Feeling with a Māori Heart}

It's how do you lead with heart, not IT or info, it's about people!

(Research participant)

Having established a theoretical platform based on whakaaro rangatira, the next step is to connect the leadership and knowledge elements to the people element, through understanding how the experience feels from the emotional and spiritual perspective. Mane, Brown-Cooper, and Armstrong-Read (2015) position the concept of ngākau Māori (Māori heart, mind soul) in terms of recognising diversity within kaupapa Māori theories and practices that in a public-sector context may mean Māori ways of knowing, being, and doing are a true authentic practice of 'Māori heart and Māori at heart' (pp. 110-111). The finding prompted the realisation that it is impossible and undesirable to create one framework for Māori L-A-P in the public sector. Within the context of the New Zealand public sector, identifying the diversity and complexity of capturing every element within the Māori world in one frame only subjects the analysis to ridicule. All models are partial. There will always be something missing. But in examining the leadership context or 
people involved within a process, the most critical question to ask is, 'Is ngākau Māori present'? Asking the question involves exploring qualities of empathy, humility, relationships and commitment to Māori. Are these qualities evident? Do they endear themselves to Māori? Can you tell whether their heart is in the right place?

The study identified the importance of personal values-based models as a critical factor for Māori leadership practice. The notion of personal leadership (Crosby, 2010, p. 49), aligned with ngākau Māori, is practicing leadership in such a way that, even under the most trying circumstances, the goal is to enhance the mana of others, to be tika (truthful) and pono (honest). Māori values-based frameworks that Māori public servants apply, as identified in the study, exemplified the essences of Māori leadership sourced from the emotional and spiritual dimensions. Participants reflected on Māori values as located within the individual, not the agency, and considered that they provide a platform of courage, aspiration, resilience, and service that come from within the individuals.

The concept of living by Māori values and with a 'ngākau Māori' speaks volumes to whānau, hapū, and iwi. It demonstrates the 'hard to explain' nuance that resonates with Māori leadership. Personal leadership requires one to sustain, maintain, and revitalise the capacity to express Māori values in a natural and giving way. For example, one participant in the study shared a personal leadership decision-making model: a selfassessment asking questions such as:

- Is this the right place for me to be?

- Does the mahi align with my values?

- Does the mahi align with what I believe?

- Does it take me closer to or further away from what I believe I should be working towards?

The key issue that arose for participants is the position of the Māori public servant on the 'waka mātauranga' (or knowledge continuum), as coined by Taiarahia Black (NZQA, 2014b). Participants recognised many Māori and non-Māori public servants are at different stages of understanding elements of the Māori world. Their Māori knowledge experience is a constant learning and growth experience. Where individuals locate 
themselves on the waka, whether as a beginner learner or with high levels of language and cultural competency, is central to their growth, development, and level of leadership contribution. As learning and lived experience grow, based on relationships, experience, and cultural identity, there is an increased capacity to create and implement distinctive Māori methodologies.

\section{The third layer: Whanaungatanga}

Returning to the Manurau conceptual framework, the dimension of collective leadership denotes whanaungatanga and the multiplicity of practices involved with forming and sustaining relationships, building support networks and models of engagement. Research participants discussed how the concept of whanaungatanga can be exploited further to ensure a critical mass of Māori public servants benefits from public sector leadership development. For example, the study identified the importance of Māori staff networks to overcome isolation and loneliness; and how Māori working in government agencies can be made to feel part of the organisation

The study demonstrated that the Māori paradigm and Māori perspective privileges the notion of collective over the individual, to maintain 'the fundamental understanding of the Māori world as an entity of people in the form of whānau, hapū, iwi, and waka. (Research participant).

Manurau suggests kaupapa Māori perspectives of leadership, such as whanaungatanga, need to be promulgated across the public sector and be accounted for as critical when leading agencies operating at the interface of Crown-Māori relationships. This is an appropriate step toward addressing inequity and reducing barriers inherent in government institutions and systems.

One transforming Māori model within the public sector that embraces the notion of whanaungatanga, particularly the health sector, is Sir Mason Durie's (1994) Te Whare Tapa Whā concept of hauora (Māori health). Te Whare Tapa Whā comprises four cornerstones of the health of Māori whānau: Te taha tinana (physical wellbeing), Te taha wairua (spiritual wellbeing), Te taha hinengaro (mental and emotional wellbeing), and 
Te taha whānau (social wellbeing). This model is pertinent to Māori leadership models; it argues that when all four dimensions are balanced the individual and overall wellbeing improves. McCann's (2016) study of 30 New Zealand public-sector chief executives revealed the influence of Māori models such as Te Whare Tapa Whā adapted by chief executives to their organisation's culture creation. The chief executives were finding value in Western and Māori models to create healthy and sustainable business cultures, to create kiwi ways of leading (p. 255).

\section{Aroha ki te tangata}

The word 'aroha' is a powerful and emotive word in the Māori language that induces elements of love, empathy, sadness, and care. The phrase 'Aroha ki te tangata' is widely used, and specifically highlighted through the Māori female case narrative. Participants reflected on and considered the many impacts on individuals who work within kāwanatanga spaces and the toll that has on whānau. From the perspective of whanaungatanga and whānau wellbeing, the concept of aroha ki te tangata emerged as a core value.

Hutia te rito o te harakeke.

Kei whea te ko(ri)mako e kō.

Kī mai ki ahau. He aha te mea nui.

He aha te mea nui o te ao.

Māku e kī atu.

He tangata, he tangata, He tangata!

The research found that formal methods of self-care for Māori public servants have not been fully explored. There was a deep concern that support systems were not in place for Māori public servants, and they were left to their own devices to find support and to feel like they belong. Furthermore, there were suggestions that there are very few, if any, safe places to kōrero about how we as Māori interact authentically and honestly. The opportunities to openly engage each other like Māori might expect to in a marae setting are not provided for. 


\section{Kia humarie}

'Kāore te kūmara e kōrero ana mō tana reka.'

'The kūmara does not talk of its own sweetness.'

Expression of humility is embedded in Māori cultural frameworks. The humility aspect is found to be contrary for public sector leadership. The whakataukī stated above is well known among Māori and non-Māori alike. It is an issue that becomes obvious in job interviews, where Māori tend not to over-emphasise their qualities and achievements. They would prefer to have others tell the panel how great they are. Research participants acknowledged that the trait of humility is not helpful for Māori public servants wishing to progress their careers, or in expressing the Māori voice. To the non-Māori eye, humility can be considered a weakness; from the Māori point of view humility is the core essence needed for developing and sustaining relationships.

There was a view among research participants that the inherent trait of humility needs to be understood as a key strength of Māori leadership, rather than a weakness. There was an argument that role-modelling humility bestows mana as a constant dynamic, and is an expression of manaakitanga and rangatiratanga. To view humility as a weakness within a leadership context demeans the concept of mana and imposes a further bias upon Māori.

From a practice perspective, the examples provided by Māori public servants identified three key important points related to humility. They are:

- be grounded and remain humble by connecting with home

- be self-aware with respect to your journey on the knowledge waka (continuum)

- be conscious of the reality and impact of your work on whānau, communities, and iwi.

The study showed that experience emphasised Māori leadership practice is about speaking up; to kōrero and engage with kaupapa in an authentic way, connecting people to the kaupapa and appropriately acknowledging those predecessors who have had to fight for the right to have a voice at the table. Māori leadership practice continues to build upon the achievements and legacies of those who have gone before and to keep the space 
open for others.

\section{Taku Mokopuna}

'Being in a reflective space because you connect your journey to the aspirations you have for your moko.' (Research participant)

Taku mokopuna is a kaupapa that emphasises reflection as a constant everyday practice. Taku Mokopuna is translated by Ngāti Awa kaumatua and long-time family friend Waaka Vercoe as 'my reflection in the spring'. This implies that just as every time you look into a spring you see a reflection of yourself, every time you see your mokopuna (grandchild), you also see a reflection of yourself. Waaka Vercoe's translation simply suggests that finding moments for reflection is an opportunity to think about your grandchildren and the future that you want for them.

Reflective practices were emphasised as being important for Māori officials. The work on educational leadership by the Education Council identified the whakataukī 'E kore au e ngaro, te kākano i ruia mai i Rangiātea' (I will never be lost, for I am a seed sown in Rangiātea) as an over-arching philosophy that challenges leaders to develop a leadership style and commitment to education that nurtures mokopuna to realise their full potential as Māori - to know who they are, to speak with a Māori voice and to protect Māori cultural wealth for future generations (Education Council, 2017).

Throughout the wānanga and interviews, research participants reflected on their personal career journey, their connections to whānau and upbringing, and the changes that have occurred over time. Māori wish to create better opportunities for their mokopuna, and mokopuna become guides for understanding whether you are having the impact that you desire.

\section{Māori leadership-as-practice principles}

The kaupapa Māori theoretical perspective suggests Māori who work for the public sector have an innate understanding of their place within kāwanatanga spaces. The study found principles and practices that guide them in their roles within government. Māori public 
servants work to ensure principles are enacted in a balanced and respectful manner. Five key principles emerged from the study:

1. The principle of good governance is to establish institutional arrangements that focus on ensuring Treaty of Waitangi obligations are met.

2. The principle of biculturalism is to create the reality of kaupapa Māori legitimacy within public administration.

3. The principle of stewardship is to preserve and protect Māori rights, interests, and values within public administration.

4. The principle of collectivism is to build unity and capability to support leadership environments.

5. The principle of manaakitanga in the public sector is to ensure generosity, care, mutual respect, and integrity.

\begin{tabular}{l|l|l} 
CROWN PRINCIPLES & TWO-WORLD PRINCIPLES & MĀORI PRINCIPLES \\
\hline Fairness & Good governance & Kaitiakitanga \\
Impartiality & Biculturalism & Wairuatanga \\
Responsiblity & Stewardship & Tapu \\
$\begin{array}{l}\text { Trustworthiness } \\
\text { Integrity }\end{array}$ & Collectivism & Māuri \\
& Manaakitanga & Tino rangatiratanga \\
& \multicolumn{2}{l}{ Table 7: Two-worlds principles for the New Zealand } \\
& public sector
\end{tabular}

Table 7 sets out 15 principles for the New Zealand public sector. In the left-hand column are five Crown principles stipulated in the State Services Commission Code of Conduct for public servants. All public servants are obliged to conform to these principles, as a requirement of their employment agreements. Māori officials subscribe to and abide by these principles when accepting employment in the public service.

In the right-hand column are five principles derived from the Māori world. These principles are specific to the Māori world, and are not found in foreign environments or contexts. Māori officials who are knowledgeable and conversant with these principles subscribe to and abide by them. 
The five two-worlds principles stated in the middle column are derived from the synthesis of lived experience and the literature (see Chapter Six), and guide practice and behaviour when the Crown and Māori world intersect. The critical difference between Māori L-A-P and general leadership in the public sector is that Māori officials traverse all three columns; non-Māori leaders traverse two columns - the Crown and two-worlds columns.

The study revealed a range of Māori leadership practices that contributed to public-sector and other organisational and leadership environments. These included:

- applying tikanga practices to bring formality, mutual understanding, reciprocity, and respect to various environments, events, and relationships

- blending knowledge from te ao Māori with te ao whānui (wider world) to balance perspectives, to create new ideas, to pursue new knowledge, to innovate, and to solve problems

- speaking with authority on matters concerning legitimacy, rights, interests, and equity

- expressing Māori values as a way of leading in everyday situations

- influencing and supporting others through change

- presenting and leading bicultural conversations.

Building on the layers on whakaaro rangatira, whakapapa kōrero, and whanaungatanga, the next layer of theoretical development of Manurau, as a conceptual practice framework, is the inter-weaving kaupapa, dimensions, goals, and outcomes of Māori leadership as practice in public administration. 


\begin{tabular}{llll} 
KAUPAPA & DIMENSION & GOAL & OUTCOME \\
\hline 1. Te Tiriti o Waitangi & Principles & Partnership & Good governance \\
\hline 2. Rangatiratanga & Power & Equity & Political \\
\hline 3. Kāwanatanga & Balance & Voice & Social Justice \\
\hline 4. Mātauranga Māori & Knowledge & Legitimacy & Biculturalism \\
\hline 5. Whanaungatanga & Relationships & Presence & Collective \\
\hline 6. Whakaaro rangatira & Thought leadership & Strategic & Resources \\
\hline 7. Manaakitanga & Care and respect & Trust & Agency \\
\hline 8. Kōkiritanga & Moving forward & Action & Results \\
\hline & & & Table 8: Manurau as a conceptual leadership
\end{tabular}

Manurau, as a conceptual framework of leadership practice, supports the notions expressed in the research that, first, the Treaty allows Māori to be here; secondly, Māori are strategic all the time; and thirdly, Māori values-based models are important for Māori leadership. The framework is by its nature dynamic, and there is a continuous interplay between kaupapa. The challenge for Māori in the public sector is to recognise the interplay and adapt their leadership practices to the context and environment they are operating in.

\section{Te Tiriti o Waitangi}

The first kaupapa practice relates to Te Tiriti o Waitangi. The underpinning of Te Tiriti o Waitangi was evident in participants' lived experience related to the core purpose of government partnership and good governance. The place of Te Tiriti o Waitangi cements the idea that Māori have a right, a place and a space inside public administration to be Māori, to express a Māori view, and for that view to be recognised as being as valid as Western views. Participants, the Māori male case study and NZQA case studies included details of forming relationships and building infrastructure to support organisations. Participants felt that this aspect of their leadership practice was the most critical. It created the appropriate level of influence and capacity to deliver on Te Tiriti o Waitangi principles and guide agencies towards equity and social justice outcomes.

\section{Rangatiratanga}

The second kaupapa practice, closely related to Te Tiriti o Waitangi, is rangatiratanga. Rangatiratanga highlights the power dynamic that exists between Māori and the Crown. 
Participants discussed how Māori public servants lack representation in power and authority roles across the system. They operate in leadership spaces with full acknowledgement that they do not have any power. This power dynamic is a reality within modern institutionalised structures, and in policy discussions. Participants talked about how Māori officials are often 'silenced' in their provision of advice, as the system is reliant and dependent upon data, evidence, and analysis, as opposed to other forms of knowledge, and discriminates against Māori ways of knowing. Participants felt that under the surface of this dynamic are layers of power that are cemented in public administration hierarchical structures and systems.

Case studies identified that Māori public servants are resilient to the issue of power, meaning that they find other ways to influence and lead in the absence of authorised power. Participants discussed how important resilience and diligence are in the preparation of advice on Māori perspectives and in how advice is communicated. Moreover, they stressed how important it is to lead and empower others - to express rangatiratanga is to address equity and to provide a wider range of options and choices for Māori.

\section{Kāwanatanga}

The third kaupapa practice is kāwanatanga. The experience of Māori officials uncovered a deep historical mistrust by Māori/iwi towards the system. Simulataneously, a pattern is emerging that as Māori/iwi settle Treaty claims and build economic power, the nature of Crown engagement is less antogonistic and more positive in terms of future arrangements. However, the notion of kāwanatanga continues to fuel the tension and challenges for both Māori and public servants, and requires public servants to have a very clear understanding of the machinery of government and the contexts and spaces they occupy. In some agencies, such as the New Zealand Police and the NZQA, there is evidence of the progress of relationships with Māori and internal organisational change as a result. The NZQA and Māori male case studies showed how Māori strategies can be effective in turning around relationships to ensure Māori voices are heard. Participants reflected on other parts of the public sector, and argued that the system is not progressing quickly enough, and, in some cases, mindsets have not changed. Participants felt that finding the balance between kāwanatanga and rangatiratanga provides a window to the Māori world 
view and capacity to access to Māori voices from which to create and support equitable and sustainable leadership environments.

\section{Mātauranga Māori}

The fourth kaupapa practice is the notion of mātauranga Māori. The legitimacy of mātauranga Māori provides the validation and impetus to engage and deliberate on equal terms. This point was raised at the first research wānanga, and was reiterated throughout the research process. Participants made consistent references to Māori epistemology, including Māori values, whakataukī, stories, and deeds of ancestors, indicating a model of sustaining Māori knowledge, creating 'mana-inspired' knowledge (Royal, 2006), and bringing energy and a life force to an organisation (Spiller \& Stockdale, 2012). Mātauranga Māori captures the essence of what it is to be Māori working in the public sector. However, participants noted that the capacity to be Māori is a learning experience for many.

Participants discussed how Māori public servants draw on other knowledge bases and global leadership experiences, too. Māori leadership practice is not exclusive. Māori public servants are competent and confident in non-Māori-specific disciplines and fields. There was a strong sense of pride that Māori public servants who are confident with mātauranga Māori, aligned with their professional skills and capacity, enjoy a cultural premium as an advantage. They are better placed to lead the bicultural conversation from a place of bicultural authenticity.

\section{Whanaungatanga}

The fifth kaupapa practice is whanaungatanga. Whanaungatanga simply refers to the process of building family relationships. It was a constant theme through the case studies and interviews. Whanaungatanga was identified as a form of leadership practice inspired by whakapapa that connects individuals to people, places, and histories and engenders a sense of belonging and identity. Participants felt it was important to understand not only your whakapapa connections but also connections to others. These connections are developed and evolve over time, and through shared experience and understanding of other kaupapa. Connections are re-established many times over in different 
circumstances. Relationships among Māori become invaluable in the work setting as they provide a level of support among Māori public servants to know that you are not alone. There are others who see the world as you do. Māori public servants value networking with other Māori and as individuals become known and respected for their achievements and for the work they do in the public sector. This creates a sense of togetherness, pride and a sense of whānau.

The case studies and interviews confirmed that 'isolation within the system' is one of the major problems identified for Māori officials. There are very few avenues for Māori to connect with each other and 'be Māori'. There is a strong tendency to get 'sucked into' the system and be constrained by work priorities and demands. This leads to Māori operating like others: too busy to make time to make connections, not willing to attend meetings or gatherings for the sake of it or where there is no obvious outcome, and 'siloed' in the way they operate. Participants recognised this as an issue, and were seeking solutions to break down the barriers.

Whanaungatanga is a process that supports networks, relationships, role models, and mentors to provide guidance to help people make decisions and find a sense of place and purpose. In the Māori female story, the challenge to move to Wellington to pursue career goals and the process of adapting to Wellington public service life created new challenges for the interviewee's whānau. She relied on Māori staff and her manager for comfort. She sought mentors and guidance. Others were generous with their time, and after two years in Wellington, she felt like she belonged. The elements of whanaungatanga are powerful in building relationships and developing a collective purpose to work together for the common good. Participants praised initiatives such as the annual inter-agency kapa haka event Te Konohete as an example of how Māori public servants can come together to celebrate being Māori, and for whanaungatanga.

\section{Whakaaro Rangatira}

The sixth kaupapa practice is whakaaro rangatira (thought leadership). Māori officials operating at this interface inherently bring with them their connection to whakapapa, whānau, and kaupapa. The conceptualisation of real-world problems and publicadministration problems, and ability to define problems well, requires discussion, 
debate, and dialogue that bring wisdom, common sense, and clarity. The approach towards whakaaro rangatira is reliant upon the steps public servants take to incorporate unique Māori experiences and perspectives into public policy and management. The research showed there is a collective propensity to engage with the Māori world and apply Māori models of thinking and leadership. The research also identified the importance for Māori public servants of being able to go home (to their iwi kāinga) (tribal home) to refresh themselves and to understand the impact of their work on whānau. This practice provided access to leadership knowledge that other public-sector leaders have limited access to. It was clear that the combination of lived and learned Māori experiences and transmission of Māori ways of thinking, visions, and ideas underpinned the notion of whakaaro rangatira as a Māori leadership practice.

\section{Manaakitanga}

The seventh kaupapa practice is manaakitanga. The expression of manaakitanga is vital to support dynamic inter-relationships occurring every day in practice. The research participants clearly demonstrated that Māori leadership practitioners live by Māori values. They show how important these values are for Māori who work in the public sector. This models an empathy, generosity, and spiritual connection to being Māori. There is a careful balance in Māori leadership practice between what feels right and what the evidence tells us is the best way forward. The cognitive application of Māori values, specifically manaakitanga, plays out as a natural instinct that through lived experience feels Māori.

\section{Kōkiritanga}

The eighth and final kaupapa practice is Kōkiritanga (moving forward together to take action). The NZQA case study showed how the whakapapa of an organisation establishes the foundations for Māori strategic frameworks; the organisation's vision, values, relationships, and legacies are part of the narrative of Māori leadership practice.

Māori strategies such as the NZQA's Te Rautaki Māori are providing agencies with Māori strategic frameworks to guide agencies, and are important to inform and record evidence of benefits for Māori and lessons learned. There is evidence of kaupapa Māori frameworks successfully contributing to leadership environments, organisational 
development, and public policy in government agencies: for example, the NZQA's Te Hono o te Kahurangi and Ngā Mātāpono. There is a need to continue this level of engagement, as there is a strong view among participants that whilst NZQA and several other agencies have made good gains, this has not gone far enough. Some of the analysis showed that the use of Māori names, holding pōwhiri, and using whakataukī are viewed as tokenism, lacking the education and sincerity to fully acknowledge and respect Māori protocol.

\section{Chapter Summary}

This chapter opened by reflecting on my tupuna ancestress Manurau and the significance of Manurau as a metaphor for collective thought leadership as an all-encompassing conceptual approach to a Māori L-A-P model.

Whakapapa is a logical place to start to theorise the methodologies of our ancestors and inquire why certain decisions and actions are taken. In the modern world, whakatauki provide great clues to recount ideas, stories, actions, and practices and reimagine and reproduce the sentiments of ancestral wisdom. Conceptualising whakataukī as a fundamental layer provides the 'papa' (foundation) for thought leadership - as a method of Māori L-A-P.

Whakapapa kōrero was introduced to the lexicon of public administration. The apprehension that this research might uncover Māori concepts that may be at risk of appropriation by the dominant power (ie, government), was discussed in the introduction of this thesis. The careful approach to the whakapapa kōrero proposal is the role Māori officials play in fulfilling the expectations of Māori to ensure that the use and application of whakapapa kōrero is consistent and compatible with Māori world views. Māori public servants face an added responsibility, that non-Māori do not have, to meet those expectations. This is another reason why whakapapa, in my case Te Arawatanga, is critically important. Ultimately, there is personal accountability - to your own whānau, hapū, iwi, and waka. 
In the study, kaupapa Māori perspectives and the methodological modes of practice emerged as critical markers. The framework encases multiple models, and connects them to a kaupapa and mātauranga Māori base.

The Manurau framework of leadership contributes to the broader scholarship on L-A-P, within the fields of public-sector leadership and public administration, by addressing the cultural and political imperatives and how lived experience brings life to Māori voices that have been inhibited within structures of kāwanatanga. There are very few safe outlets for Māori public servants to speak up or speak out. Inevitably, Māori voices find strength within a collective framework, and in this way make sense of the situation to influence and contribute to other leadership contexts and environments. This research finds synergies with the discourse of indigenous leadership, mana wahine leadership, and kaupapa Māori notions of transforming leadership. 


\section{Chapter Eight: Conclusion}

This thesis has endeavoured to close the gap in the literature about Māori leadership practice in the public sector in New Zealand. The thesis shows that Māori leadership practices exist within government agencies and are changing, with kaupapa Māori perspectives underpinning strategic, collective and action-oriented priorities. The context of the two worlds illuminates Māori leadership practices at the rangatiratangakāwanatanga interface, and shows how it is balanced by connecting values-based models with reality and experience. The research found that Māori leadership practice is a specialised form of leadership practice that requires public servants to walk in two worlds, guided by key principles, values, and understanding of the context. Despite this thesis's contribution, there is still more work to do in the field of public administration to develop Māori leadership scholarship and create the critical scale of understanding necessary for change in a post-Treaty modern public sector. This final chapter provides a summary of the findings, reflections, challenges, and limitations of the research.

\section{Kaupapa Māori Perspectives of Leadership - a Glance Back}

The research idea posited the notion of Māori leadership practice in public administration as the embodiment and expression of the Māori world in the public sector. The first part of the research question was 'What is Māori leadership practice?' The answer to this question was found by applying a kaupapa Māori framework to explore leadership practice through the lenses of rangatiratanga, manaakitanga, whanaungatanga, and mana. The research was designed within a kaupapa Māori ethical framework to give effect to the lived experiences of Māori officials, including my own, who operate at this interface, and to reveal the leadership practices that emerge when Māori officials are operating in two worlds. This research analysed the Māori narratives of 34 senior Māori officials from 16 government agencies and Crown entities between 2014 and 2017. During this period participants engaged in two research wānanga and interviews. Specific case narratives provided deep-dive perspectives.

The second part of the research question was 'How is Māori leadership practice enacted in government agencies?' To answer this part of the question, a detailed organisational case analysis of the New Zealand Qualifications Authority (NZQA) was undertaken. The 
implementation of consecutive NZQA Māori strategies between 2007 and 2017 provided a living example of enactment and the associated implications. Some guidance was also found in the review of the literature on kaupapa Māori theory and Māori leadership. Māori concepts were synthesised with literature in the fields on public administration, leadership theory, and Māori leadership. Critical analysis applied an interpretative approach using sense-making techniques and whakapapa analysis to explore Māori narratives. The analysis identified a significant shift towards a modern view of Māori leadership closely associated with a future-focused post-Treaty settlement environment and a global outlook on the place and contribution of Māori leadership to Aotearoa New Zealand.

\section{Key Findings}

Manurau represents a collective of a hundred birds who seek solace and wisdom in Māori knowledge and use that knowledge in modern contexts to provide insight, intelligence and thought leadership.

One of the key findings of this thesis concerned the changing nature of Mãori leadership practice. The research found the importance of how Māori leadership has adapted to influence authorising environments inside the government bureaucracy. Māori officials have adapted the model from a traditional cultural model to a model that is focused on legitimate governance to enable access to voice, influence, and power. In that sense, this thesis concurs with Graham Smith (2015) that Māori leadership practice in public administration is a 'transforming leadership praxis'.

The research found that the role of the chief executive, relationships with Māori, Māori values, and relevant strategic and action-oriented work formed the framework for enacting Māori leadership in government agencies. These findings would be of no surprise to Māori leaders and scholars in other workplace environments within contexts of organisational development, business, corporate governance, and international indigenous settings. The goal to introduce kaupapa Mãori ways of thinking and doing within other environments continues to be a focus for Māori, and there is a growing body 
of research and literature to advocate for greater attention in these areas. The common notions of Māori leadership practice in public administration are:

1. Know who you are. Be yourself.

2. Know what difference you bring and the added value you contribute.

3. Contribute your life experience in combination with te reo Māori and formal education.

4. Know how the system works.

5. Learn how to survive in an institutionalised culture.

6. Challenge the status quo and do not deliver more of the same.

7. Be transforming.

The study shows that there is a pattern of change occurring that reflects the advances being made with Treaty of Waitangi settlements, a growing Māori economy, and a maturing relationship between Māori and the Crown. In my analysis of the changing leadership model, I concluded that the pattern is shifting from a traditional-cultural and political leadership model towards a modern culturally responsive, executive leadership model. No longer are the Māori leadership roles just about traditional Māori cultural practices. The culturally responsive executive leadership model is an operating model that is still underpinned by cultural practices and competencies, but it also involves four inter-disciplinary dimensions of leadership that are dynamic and inter-related depending on the context:

1. transforming Leadership - the rangatiratanga dimension

2. Leader-follower relations - the whanaungatanga dimension

3. Active stewardship - the manaakitanga dimension

4. Critical guardianship - the kaitiakitanga dimension.

The research participants epitomised the contemporary model, demonstrating a strong sense of professionalism in their outlook and position within two worlds. They were educated in two worlds, confident, articulate, and resolute in their commitment to Māori and equally confident and professional in their roles in the public sector. Research 
participants felt that kaupapa and mātauranga Māori was integral to their identity as public servants, and these were enabling elements rather than constraining elements.

The contribution of 'Māori' to the theoretical frameworks of Leadership-as Practice reveals there is a Māori method of leadership. The case studies and interviews identified that in the public-sector environment Māori methodologies are evident as Māori officials position themselves relative to daily tasks or situations. The methods give precedence to kaupapa Māori priorities as a) political: power, voice, and equity, b) cultural: mātauranga, tikanga, te reo Māori, and wairuatanga, and c) executive: planning, positioning, and people.

The research identified Māori L-A-P in New Zealand's public administration as a body of knowledge and scholarship that can be developed further. There is a range of elements drawn from both traditional and modern models that constitutes Māori leadership in the context of the public sector, and by setting out a Māori leadership framework other scholars and researchers are now able to critically explore and expand on this foundation. The research found evidence of practice and the relationship between these practices and mātauranga-based skills. The research argues that kaupapa and mātauranga Māori creates and affirms new and innovative practices and hence creates public value through diversity and enterprise thinking.

The research acknowledges that not all Māori officials are the same or have the same level of knowledge or understanding and connection with the Māori world. Participants were at different stages of their life journey and relationship with te ao Māori, but they would call upon what they know and use whanaungatanga as an underpinning force to overcome this issue. Whanaungatanga in this scenario aligns with the notions of leaderfollower relationships, networking, role models, support, and mentoring. The research identified that further work is needed to understand and appreciate the necessity of whanaungatanga as a development opportunity. 


\section{Original Contributions to the Literature}

The perspectives of kaupapa and mātauranga Māori have not been considered in the literature on leadership in public administration. This thesis brings kaupapa and mātauranga Māori to light in the context of the public-sector leadership discourse. The Māori world - its philosophies, narratives, and histories - presents an amazing plethora of concepts, dimensions, and stories. It is a world that one navigates carefully, particularly when you are a Māori researcher and public servant living the experience. The contribution focuses Māori leadership practice in kāwanatanga contexts as embedded within a process of engaging with the Māori world.

This thesis introduces Manurau to the field of leadership, as a conceptual framework that encompasses three foundational layers upon which Māori leadership elements can be recognised. Manurau found links with the notion of L-A-P and discovered the rich cultural elements that differentiate Māori leadership practice from Western forms of leadership. The strategic, collective, and action-orientated elements that were found ensure a literary contribution that supports the idea that Māori leadership in public administration is no longer about singular leaders; it is about the collective, indicating a movement towards the appreciative use of Māori concepts such as manaakitanga and whanaungatanga as critical factors in Māori leadership development.

The approach this research took, to explore from an insider Māori perspective, has presented many rewards. As I read, listened, and traversed the voices of experience, I developed an intense curiosity. I identified gems that resonated with me early in the research process and remained constant throughout. The first gem is articulated in a quote from a research participant:

the only way to engage with the Mãori world was to engage through the Mãori world, through mātauranga and kaupapa Māori, seeing through the eyes of Māori.

This resonated because it not only concurred with my story but also validated the experience of others. Something landed. If we are to think about Māori leadership practice in the public sector, the starting point is to consider leadership practice from the 
Māori perspective. The alternative is to consider Māori leadership practice from the 'outsider looking in' view and the dominant perspective: Western knowledge. To do this only continues to perpetuate a system that creates unconscious and conscious bias and reiterates the notion of sameness as the entrenched norm. As the quote implies, the dynamism occurring within the Manurau framework creates emotion, passion, spirit, commitment, and drive. Māori officials, because of their professionalism, life experience, education, and resilience, demonstrate this unique capability of leadership, as Māori.

The thesis achieved its goal to identify, describe, and elaborate on Māori leadership practice in public administration. Answering the research questions, it lays out a framework, based on mātauranga and kaupapa Māori, for the public sector and academia to interrogate further and ask more questions. By doing this, it presents an opportunity for public sector leaders and academics to engage in a meaningful and respectful dialogue about the place of Māori leadership practice in the public sector.

\section{Research Challenges and Mitigation}

Writing this thesis has presented many challenges. I began this thesis with many preconceived notions of Māori leadership based on my personal lived experiences with Māori leaders operating at the interface in my early formative years. As an insider researcher, practitioner, and Māori, I faced a risk of jumping to conclusions and being swayed by personal views or by the way information was presented, particularly if I had an affinity with the participant or perspective. There was a potential for bias that had the potential to reduce the validity of this work (Kayrooz \& Trevitt, 2004, p. 4). These challenges and risks were mitigated by researcher self-awareness and an alertness to predispositions to view events in certain ways, and careful alignment of context, purpose, approach, design, and methods, supported by academic supervision, cultural guidance, and support from public-sector leaders (Kayrooz \& Trevitt, 2004, p. 5).

The development of the research framework and interactions with my supervisors mitigated the challenge of potential bias. Supervisors helpfully enabled a careful plan to execute the research process, to systematically collect and analyse data and find truth and validation (Kayrooz \& Trevitt, 2004, p. 4). This included examining global and indigenous theoretical perspectives of L-A-P, leadership context, and leadership 
perspectives as critical parameters to position Māori leadership in the New Zealand public sector. The notion that the two-worlds phenomenon exists for Māori public servants percolated as a contextual element that could not be ignored. The research was curious to know what differentiated leadership practices emerge at the Crown-Māori interface, and how these practices can be regarded as uniquely Māori. I was encouraged to speak from my personal voice of experience and to not shy away from telling my story.

A kaupapa Māori theoretical framework positioned the research lens to privilege lived experiences and Te Arawatanga as relevant and applicable to this study. Kaupapa Māori theory also gives confidence to Māori insider researchers doing research in a kāwanatanga context. It provides a protective layer for Māori researchers who walk in two worlds. The appropriate tools, such as tikanga, kaupapa, mātauranga, and whakapapa, are accessible and validated kaupapa Māori perspectives of leadership practice. The research framework adds to the knowledge that kaupapa Māori perspectives of leadership are relevant alongside other forms of public sector leadership.

\section{Limitations of the Research}

The decision to start with a broad framework of voices of lived experience was appropriate to ensure the perspectives of those with lived experience, who had progressed through the ranks, worked in the regions and had experience in the halls of bureaucracy in Wellington. The approach is, in my view, one of the strengths of the research. However, if there is a limitation it is in the depth of Māori voice heard; for example, the study could have focused on tier 2 Māori officials only, an under 40 years age-cohort only, or Māori working in the regions only, rather than a broader group. These options present themselves as possibilities for further research.

\section{Possibilities for Further Research}

Much more research is needed to build knowledge and understanding between the worlds of public administration and Māori and indigenous peoples. As alluded to earlier, specific cohorts of public servant experience are worthy of further study. Specific perspectives, such as mana wahine, iwi perspectives of Crown-Māori relationships, could be the focus of doctoral study. Further research is needed on how government agencies 
and systems consider Māori and indigenous perspectives, exploring barriers and ways to overcome bias.

There is a space to undertake further research into the implications of introducing kaupapa and mātauranga Māori into government agencies. There is an opportunity for further research to build high-level understanding and scholarship around public sector chief executives' leadership practices from a Māori perspective. There is also an opportunity for further research to explore the recognition of mātauranga Māori and kaupapa Māori as a legitimate source of policy advice, data, and evidence to be equally considered alongside Western forms of data and evidence, including international evidence. Policy-makers need to consider Māori and indigenous knowledge on equal terms and understand the nuance of leadership practice as a specialised capacity in formulating and presenting mātauranga and kaupapa Māori-based evidence. Such research in these areas could potentially change the way how organisational leaders and policy-makers think about Māori knowledge. Further research is necessary to build public sector capability and agency performance relating to obligations to the Treaty of Waitangi, recognition of kaupapa and mātauranga Māori, and delivery of public value.

\section{Concluding Remarks}

The first challenge the research discovered is the ability to articulate a Māori voice so that it may be received as authentic and untarnished by the dominant and persistent bias within the context of public administration. This thesis shows the reality and lived experience of Māori leadership and the extent to which bias is experienced on a daily basis. Bias is a constant tension. Māori narratives explain that to overcome this tension a certain type of leadership is required, and that as Māori, you call upon Māori elements to give you the courage, resilience, humility, and strength to stand up and speak up. Māori diversity adds constructive and positive insight to the issues at hand, and at the same time seeks to enhance the mana of all concerned.

The contribution of this thesis to the body of knowledge about Māori leadership is to understand the depth of spiritual and emotional connection and relationship between Māori who work for government agencies and the environment within which they work. 
There exists a deep and profound connection between the role of the Māori public servant, kaupapa, mātauranga, and leadership practice. The research found Māori public servants bring their deliberate acts of leadership into the space. When they bring these things together the experience looks and feels like it is leadership - Māori leadership.

This thesis is the culmination of my personal journey, thus far, walking in the two worlds of rangatiratanga and kāwanatanga. When I started to think about the notion of Māori leadership in the public sector, it was based upon my personal lived experience walking alongside people who I saw as Māori leaders who were working for the government. My insider experience too created a strong sense of empathy and understanding. I had been there too. I had certainly experienced similar situations. As I observed the phenomenon over a long period of time, I was captivated by their deep sense of service. I too found my own personal leadership journey was enriched by embracing a philosophy of service and found purpose for my life's work. I wanted to make a contribution too - to make a difference. The work of Māori leadership in public administration is to advance mātauranga and kaupapa Māori, for it is through the 'seeing through the Māori world' that practices of Māori leadership in public administration emerge.

The perspective of lived Māori experience engendered great anticipation and a sense that finally, a collective Māori voice would emerge from the research that would acknowledge Māori leadership contributions to the public service. This thesis articulates a world view of public sector leadership that has not been published in the academic fields of publicsector leadership. This thesis answers a lot of questions about the role and place of Māori knowledge, kaupapa Māori perspectives of leadership, and Māori leadership practices in New Zealand's public sector. This thesis therefore provides a 'starting point' that legitimates the Māori public servant leadership contribution to New Zealand's public service and advocates for greater recognition and validation of Māori leadership practice and indigenous leadership in public administration globally. 


\section{References}

Althaus, C. (2014). Leading from between: Indigenous leadership in the public services of British Columbia, Queensland and New Zealand. Retrieved from http://griffith.edu.ac/business-government/centregovernance-public-policy/news/previous-centre-highlights/highlight-catherine-althaus-seminar

Ancona, D. (2005). Leadership in an age of uncertainty. MIT Sloan Centre for eBusiness Research Brief, 6(1). Retrieved from http://ebusiness.mit.edu/research/Briefs/Ancona_Leadership_Final_VI.pdf

Ballara, A. (1998). Iwi: the dynamics of Māori tribal organisations from c 1769 to c 1945. Wellington, New Zealand: Victoria University Press.

Barzelay, M. (2007). Learning from second-hand experience: methodology for extrapolation-oriented case research. Governance: An International Journal of Policy, Administration and Institutions, 20(3), 521-543.

Battiste, M. (Ed.). (2000). Reclaiming indigenous voice and vision. Vancouver: University of British Columbia Press.

Best, E. (1898). Omens and superstitious beliefs of the Māori. Journal of the Polynesian Society, 7, 119-36.

Bevan-Brown, J. (1998). By Māori, for Mãori, about Māori: is that enough? In Te P Hauora (Ed.),

Proceedings of Te Oru Rangahau (pp. 231-246). Palmerston North, New Zealand: Massey University.

Beverley, J. (2000). Testimonio, subalternity, and narrative authority. In N. Denzin \& Y. S. Lincoln (Eds.), Handbook of qualitative research (2nd ed., pp. 555-566). Thousand Oaks: Sage.

Billing, P. B. (2004). Leadership of the Tainui people. Te Kauwhata, New Zealand: Mitaka Ra Publications.

Bishop, R. (2008). Te Kotahitanga: kaupapa Māori in mainstream classrooms. In N. K. Denzin, Y. S. Lincoln, \& L. T. Smith (Eds.), Handbook of critical and indigenous methodologies (pp. 439-458). Thousand Oaks, USA: Sage Publications.

Bishop, R., \& Glynn, T. (2003). Culture counts: changing power relations in education. London, England: Zed Books.

Black, T. (Ed.) (2014). Enhancing mātauranga Māori and global indigenous knowledge. Wellington, New Zealand: New Zealand Qualifications Authority.

Bolden, R., Petrov, G, \& Gosling, J. (2008). Tensions in higher education leadership: towards a multi-level model of leadership practice. Higher Education Quarterly, 62, 358-376.

Boston, J., \& Gill, D. (2011). Working across organisational boundaries: the challenges for accountability. In B. Ryan and D. Gill (Eds.), Future state: directions for public management in New Zealand. Wellington, New Zealand: Victoria University Press.

Bromell, D. (2012). Creating public value in the policy advice role: a reflection from the front line. Policy Quarterly, 8(4), 16-22.

Brougham, A. E., \& Reed, A. W. (1999). The Reed book of Māori proverbs. Auckland: Reed.

Burns, C, (Ed.). (1982). The path to reform: reform from within? Wellington, New Zealand: New Zealand Institute of Patent Attorneys.

Cajete, G. A. (2016). Indigenous education and the development of indigenous community leaders. Leadership, 12(3), 364-376.

Calliou, B. (2005). The culture of leadership: North American indigenous leadership in a changing economy. In D. Champagne, K. J. Torjensen, \& S. Steiner (Eds.), Indigenous peoples and the modern state (pp. 47-68). Toronto, Canada: Altamira Press. 
Chapman \& Tripp. (2017). Te Ao Māori: Trends and Insights. Chapman Tripp. Retrieved from www.chapmantripp.com.

Chen, M. (2012). Public law toolbox: solving problems with government. Wellington, New Zealand: LexisNexis.

Coghlan, D. (2003). Practitioner research for organisational knowledge: mechanistic and organisticoriented approaches to insider action research. Management Learning, 34(4), 341-463.

Cohen, L., Manion, L., \& Morrison, K. (2000). Research methods in education (5th ed). London, England: RoutledgeFalmer.

Costley, C., Elliott, G., \& Gibbs, P. (2010). Doing work based research. London, England: Sage Publications.

Cram, F. (2009). Maintaining Indigenous voices. In D. Mertens, \& P. Ginsberg (Eds.), SAGE Handbook of social science research ethics (pp. 308-322). Thousand Oaks, USA: Sage Publications.

Cram, F., \&. Pipi, K. (2000). Māori/iwi provider success: report on the pilot project. International Research Institute for Māori and Indigenous Education: Auckland, New Zealand.

Crevani, L., Lindgren, M., Packendorf, J., (2010). Leadership not leaders: On the study of leadership as practices and interactions. Scandinavian Journal of Management, 26, 77-86.

Cribb, J. (2006). Agents or stewards? Contracting with voluntary organisations. Policy Quarterly, 2(2), 1117.

Crosby, B. C. (2010). Leading in the shared-power world of 2020. Public Administration Review, 70 (1), 69-77.

Crosby, B. C., \& Bryson, J. M. (2005). Leadership for the common good: tackling public problems in a shared power world. San Francisco, USA: Jossey-Bass.

Crotty, M. (1998). The foundations of social research: meaning and perspective in the research process. London, England: Sage Publications.

Curnow, J. (2012). Story: Te Rangikaheke, Wiremu Maihi, from the Dictionary of New Zealand Biography. In Te Ara: the encyclopedia of New Zealand. Retrieved from http://www.teara.govt.nz/en/biographies/1t66/te-rangikaheke-wiremu-maihi

Denzin, N. K., \& Lincoln, Y. S. (2000). Introduction: the discipline and practice of qualitative research. In N. K. Denzin, \& Y. S. Lincoln (Eds.), Handbook of qualitative research (2nd ed.). London, England: Sage Publications.

Devault, M. L. (1990). Talking and Listening from Women's Standpoint: Feminist Strategies for Interviewing and Analysis. Social Problems. 37(\#1): 96-116.

Diamond, P. (2003). A fire in your belly: Mãori leaders speak. Wellington, New Zealand: Huia.

Doherty, W. (2012). Ranga framework: he raranga kaupapa. In T. Black, D. Bean, W. Collings, \& W. Nuku, Conversations on mātauranga Māori, New Zealand Qualifications Authority (pp. 15-35). Wellington, New Zealand: Haemata.

Donaldson, L., \& Davis, J. (1991). Stewardship theory or agency theory: CEO governance and shareholder returns. Australian Journal of Management, 16 (1), 49-65.

Durie, M. (1993), Māori and the state: professional and ethical implications for a bicultural public service. In Conference proceedings of the public service senior management conference (pp. 23-35). Wellington: State Services Commission. 
Durie, M. (2003). Ngā Kahui Pou Launching Mäori Futures. Wellington, New Zealand: Huia Publishers, Wellington, pp. 213-228.

Durie, M. (2004a, April). An indigenous model of health promotion. Paper presented at the 18th World Conference on Health Promotion and Health Education, Melbourne, Australia.

Durie, M. (2004b, March). Exploring the interface between science and indigenous knowledge. Paper presented at the 5th APEC Research and Development Leaders Forum, 'Capturing Value from Science', Christchurch, New Zealand.

Durie, M. (2004c). Public service reform, indigeneity, and the goals of Mãori development. Paper presented at the Comonwealth Advanced Seminar, Wellington, New Zealand. Retrieved from http://www.massey.ac.nz/massey/learning/departments/centres-research/te-mata-o-tetau/publications/publications_home.cfm.

Durie, M. (2011). Nga tini whetu: navigating Māori futures. Wellington, New Zealand: Huia Publishers. Wellington.

Education Council. (2017). Leadership strategy: synthesis of views from the Mãori leadership forum. Wellington, New Zealand: Education Council.

Edwards, S. (2009). Titiro whakamuri kia marama ai te wao nei: whakapapa epistemologies and Maniapoto Maori cultural identities (Unpublished doctoral thesis). Massey University, Palmerston North, New Zealand.

Edwards, S. (2012). Nā te mātauranga Māori ka ora tonu te ao Māori: through Māori knowledge will resonate. In T. Black, D. Bean, W. Collings, \& W. Nuku, Conversations on mātauranga Māori, New Zealand Qualifications Authority (pp. 37-58). Wellington, New Zealand: Haemata.

Eppel, E., \& Wolf, A. (2012). Implementing Better Public Services. Policy Quarterly, 8(3), 41-48.

Evans, M., \& Sinclair, A. (2016). Containing, contesting, creating spaces: leadership and cultural identity work among Australian Indigenous arts leaders. Leadership, 12(3), 270-292.

Fairholm, M. R. (2004). Different perspectives on the practice of leadership. Public Administration Review, 64(5), 577-590.

Fogarty, C. (2006). Sir Tipene O’Regan: front foot leadership. Leadership NZ, Winter.

Ford, J., \& Harding, N. (2007). Move Over Management: We're all Leaders Now. Management Learning, $38(5), 475-493$.

Forster, M., Palmer, F., \& Barnett, S. (2016) Karanga mai ra: Stories of Māori women as leaders. Leadership, 12(3), 324-345.

Friere, P. (1985). Pedagogy of the oppressed. London, England: Penguin.

Gardiner, W. (2014). Parekura Horomia. 'Kia ora, chief!'. Wellington, New Zealand: Huia.

Gronn, P. (2002). Distributed leadership as a unit of analysis. Leadership Quarterly, 13, 423-451.

Hammersley, M. (2000) Taking sides in social research: essays on partisanship and bias. London, England: Routledge.

Hammersley, M. \& Gomm, R. (1997). 'Bias in Social Research', Sociological Research Online, vol 2, no.1, http://www.socresonline.org.uk/2/1/2.html 
Harmsworth, G. R., \& Awatere, S. (2013). Indigenous Māori knowledge and perspectives of ecosystems. In J. R. Dymond (Ed.), Ecosystem services in New Zealand: conditions and trends. Lincoln, New Zealand: Manaaki Whenua Press.

Harris, F., MacFarlane, S., MacFarlane, A., \& Jolly, M. (2016). Māori values in the workplace: Investing in diversity. MAI Journal, 5(1), 49-62.

Harvey, B. (2007). Dr Pita Sharples: leadership and mana. Profile. Leaders, Winter, 19.

Held, D. (2006). Models of democracy (3rd ed). Stanford, USA: Stanford University Press.

Henare, M. (1998). Koru of Māori ethics. Retrieved from http://www.rangahau.co.nz/ethics/168/

Henare, M. (2010). Māori academic leadership. Presentation at Waipapa Marae, University of Auckland, Auckland, New Zealand.

Henry, E. (1994). Rangatira wahine: Māori women managers and leadership (Unpublished master's thesis). University of Auckland, Auckland, New Zealand.

Henry, E. (2008). Kaupapa Māori entrepreneurship: traditional Māori concepts applied to sustainable business development. Paper presented at the Nga Pae o Te Maramatanga Traditional Knowledge Conference, Auckland, New Zealand.

Henry, E., \& Wolfgramm, R. (2015). Relational leadership: an indigenous Māori perspective. Leadership, 14 (2), 1-17. D. Sage Publications.

Henry, E., \& Pene, H. (2001). Kaupapa Māori: locating indigenous ontology, epistemology and methodology in the academy. Organization, 8(2), 234-242.

Higgins, R., \& Meredith, P. (2011). Ngā tamariki: Māori childhoods. In Te Ara: the encyclopedia of New Zealand. Retrieved from http://www.TeAra.govt.nz/en/nga-tamariki-maori-childhoods/print

House, R.J., Hanges, P.J., Javidan, M., Dorfman, P.W., \& Gupta, V. (2004). Culture, Leadership and Organisations. The GLOBE Study of 62 Societies. Thousand Oaks: Sage Publications.

Hudson, M., Milne, M., Reynolds, P., Russel, K., \& Smith, B. (2010). Te ara tika: guidelines for Māori research ethics: a framework for researchers and ethics committee members. Retrieved from http://www.hrc.govt.nz/sites/default/files/Te\%20Ara\%20Tika\%20Guidelines\%20for\%20Maori\%20Re search\%20Ethics.pdf

Ihimaera, W., et al., (1993). (Eds.). Te Ao Mārama. Regaining Aotearoa: Māori writers speak out. Volume 2. He whakaatanga o te ao. The reality. Auckland: Reed.

Irwin, K. (1992). Towards theories of Māori feminism. In R. DuPlessis (Ed.), Feminist voices: women's studies text for Aotearoa (pp. 1-21). Auckland, New Zealand: Oxford University Press.

Irwin, K., Hetet, L., MacLean, S., (2013). What Works with Māori: What the people said. Wellington, New Zealand: Families Commission.

Jackson, A. M. (2013). A discursive analysis of rangatiratanga in a Māori fisheries context. MAI Journal, 2(1), 3-17.

Jackson, B., \& Jones, O. S. (2012). Promoting better public services leadership: an appreciative critique. Policy Quarterly, 8(3), 34-40.

Jackson, B., \& Parry, K. (2008). A very short, fairly interesting and reasonably cheap book about studying leadership. London, England: Sage Publications.

Jarvis, P. (1999) The practitioner-researcher: developing theory from practice. San Francisco, USA: JosseyBass. 
Johnson, R. B., \& Christensen, L. (2008). Educational research: quantitative, qualitative and mixed approaches (3rd ed.). Thousand Oaks, USA: Sage Publications.

Katene, S. (2001). Leadership in the public health sector: Māori perspectives. Unpublished Masters research project. Victoria University, Wellington.

Katene, S. (2010). Modelling Māori leadership: What makes for good leadership? MAI Review, 2, 1-16.

Katene, S. (2013). The spirit of Mãori leadership. Wellington, New Zealand: Huia.

Kayrooz, C., \& Trevitt, C. (2004). Research in organisations and communities: tales from the real-world. Crows Nest, NSW: Allen \& Unwin.

Kelly, D., Jackson, B., \& Henare, M. (2014). 'He apiti hono, he tātai hono': ancestral leadership, cyclical learning and the eternal continuity of leadership. In R. Westwood, G. Jack, F. R. Khan, \& M. Frenkel, Coreperiphery relations and organisation studies (pp. 164-184). Hampshire, England: Palgrave Macmillan.

Kenny, C. (1998). The Sense of Art: A First Nations Perspective. Candian Journal of Native Education, 22(1), 77-84.

Kenny, C., \& Ngāroimata-Fraser, T. (2012). Living indigenous leadership. Vancouver, Canada: UBC Press. King, M. (2003). The Penguin history of New Zealand. Auckland, New Zealand: Penguin.

Kirton, G., \& Healy, G (2012). 'Lift as you rise': Union women's leadership talk. Human Relations, 65(8), 979-999.

Leadership Development Centre. (2012). Developing and stewarding Māori leadership. Wellington, New Zealand: Leadership Development Centre.

Leck, G. M. (1994). Queer relations with educational research. In A. Gitlin (Ed.), Power and method. London, England: Routledge.

McCann, J. (2016). Kiwi ways of leading: How 30 New Zealand government chief executives are encouraging healthier cultures. In K. G. Schuler (Ed.), Creative social change: leadership for a healthy world (pp. 245-262). San Francisco, USA: Emerald Publishing.

Macfarlane, A., Webber, M., Cookson-Cox, C., \& McRae, H. (2014). Ka awatea: an iwi case study of Mãori students' success. Retrieved from

http://www.maramatanga.co.nz/sites/default/files/Ka\%20Awatea\%20-\%2031\%20March.pdf

Mahuika, R. (2008). Kaupapa Māori theory is critical and anti-colonial. MAI Review, 3, Article 4.

Main, F. M. (2005). Aboriginal public servants: leadership in the British Columbia public service. (Unpublished master's thesis). University of Victoria, Victoria, Canada. Retrieved from https://dspace.library.uvic.ca:8443/bitstream/handle/1828/5255/Main_Fionna_MPA_2014.pdf?sequenc $\mathrm{e}=1$ \&isAllowed $=\mathrm{y}$

Mane, J., Brown-Cooper, P., \& Armstrong-Read, A. (2015). Whanaungatanga as pedagogical leadership. In N. Williams, J. Carroll-Lind, \& L. Smith (Eds), Tōku anō ao Māori: my very own world. Te Rito Maioha.Occasional Paper Series. Number 2.

Manzie, S., \& Hartley, J. (2013). Dancing on ice: leadership with political astuteness by senior public servants in the UK. Milton Keynes, England: Open University Business School.

Marsden, M. (1992). Kaitiakitanga: a definitive introduction to the holistic world view of the Maori. New Zealand: Ministry for the Environment.

Marsden, M. (2003). The Woven Universe: selected writings of Rev. Māori Marsden. Ōtaki: Te Wānanga o Raukawa. 
Mead, A. (1994). Māori leadership. Paper presented at the Hui Whakapumau Māori Development Conference, Massey University, Palmerston North, New Zealand.

Mead, H. (2003). Tikanga Mãori model. Retrieved from http://www.rangahau.co.nz/ethics/167/

Mead, H. (2012). Understanding mātauranga Māori. In T. Black, D. Bean, W. Collings, \& W. Nuku, Conversations on mātauranga Māori, New Zealand Qualifications Authority (pp. 37-58). Wellington, New Zealand: Haemata.

Mead, H., Stevens, S., Third, J., B. Jackson \& Pfeifer, D. (2005). Māori leadership in governance. In Hui Taumata leadership in governance scoping paper (pp. 3-35). Wellington: Hui Taumata.

Mead, L. T. R. (1996). Te aho o te kakahu matauranga: the multiple layers of struggle by Maori in education (Unpublished doctoral dissertation). University of Auckland, Auckland, New Zealand.

Meredith, P., \& Higgins, R. (2012). Kāwanatanga: Māori engagement with the state: defining kāwanatanga. In Te Ara: the encyclopedia of New Zealand. Retrieved from http://www.Te Ara.govt.nz/en/kāwanatangamāori-engagement-with-the-state/page-1

Metge, J., \& Kinloch, P. (1978). Talking past each other: problems of cross-cultural communication. Wellington, New Zealand: Victoria University Press.

Ministry of Education. (2010). Tu rangatira: Mãori medium educational leadership. Wellington, New Zealand: Ministry of Education.

Moko-Mead, H., \& Grove, N. (2003). Ngā pēpeha a ngā tīpuna: the sayings of the ancestors. Wellington, New Zealand: Victoria University Press.

Moore, M. (1995). Creating public value: strategic management in government. Cambridge: Harvard University Press.

Mulgan, R. (2012). What future for free and frank advice? Policy Quarterly, 8(4), 3-10.

Mutch, C. (2005). Doing Educational Research: A Practitioner's Guide to Getting Started. New Zealand Council for Educational Research. Wellington, New Zealand: NZCER Press.

Nepe, T. (1991). E hao nei e tenei reanga te toi huarewa tupuna: kaupapa Mãori, an educational intervention system (Unpublished master's thesis). University of Auckland, Auckland, New Zealand.

New Zealand Herald. (2006). Corrections changes Maori policy after Bullock case. 18 January, New Zealand Press Association.

New Zealand Institute of Directors. (2012). The four pillars of governance best practice. Wellington, New Zealand. New Zealand Institute of Directors.

New Zealand Police. (2014). A review of police and iwi/Māori relationships: working together to reduce offending and victimisation among Māori. Retrieved from http://www.police.govt.nz/sites/default/files/publications/review-of-police-and-iwi-maorirelationships.pdf

New Zealand Qualifications Authority.(2007a). Te Rautaki Māori a te Mana Tohu Mātauranga o Aotearoa 2007-2012. Wellington. New Zealand: NZQA.

New Zealand Qualifications Authority. (2007b). NZQA Code of Conduct. Wellington, New Zealand. NZQA. Retrieved from http://www.nzqa.govt.nz/assets/About-us/Working-for-NZQA/NZQA-Code-ofconduct.pdf

New Zealand Qualifications Authority. (2009). Hui Mana Tohu Mātauranga: Book of Proceedings. Wellington, New Zealand: NZQA. 
New Zealand Qualifications Authority. (2010). Effective engagement with Māori: a review of the literature and interviews with stakeholders. Report for the Deputy Chief Executive Mãori. Wellington, New Zealand. NZQA.

New Zealand Qualifications Authority. (2012a). Ngā taputapu arotakenga: matauranga Mãori evaluative quality assurance. Retrieved from http://www.nzqa.govt.nz/maori/mm-eqa/nga-taputapu-arotakenga/

New Zealand Qualifications Authority. (2012b). NZQA: The journey with mātauranga Māori. In Conversations on mātauranga Mãori, New Zealand Qualifications Authority (pp. 95-110). Wellington, New Zealand: Haemata.

New Zealand Qualifications Authority. (2012c). Te Rautaki Māori a te Mana Tohu Mātauranga o Aotearoa 2012-2017. Wellington, New Zealand: NZQA.

New Zealand Qualifications Authority. (2014a). Statement of Intent 2014/15-2017/2018. Wellington, New Zealand: NZQA.

New Zealand Qualifications Authority. (2014b). Enhancing mātauranga Māori and global indigenous knowledge. Wellington, New Zealand: NZQA.

New Zealand Qualifications Authority.(2017a).Targeted Review of Qualifications. Wellington, New Zealand. NZQA.Retrieved from http://www.nzqa.govt.nz/qualifications-standards/qualsdevelopment/targeted-review-of-qualifications/

New Zealand Qualifications Authority.(2017b). Guidelines for Te Hono o Te Kahurangi Evaluative Quality Assurance. Wellington, New Zealand. NZQA. Retrieved from http://www.nzqa.govt.nz/assets/Maori/TeHono-o-te-Kahurangi/guidelines-te-hono-o-te-kahurangi-2017.pdf

Ngā Tuara. (1992). Ngā toka tū moana: Māori leadership and decision making. Wellington, New Zealand: Te Puni

Kōkiri.

Ngaropo, P. (2015). Tātai kōrero: the history of the chief Tūhourangi from the Tūhourangi Marae charter. Unpublished.

Nkomo, S. \& Kriek, D. (2011). Leading organizational change in the 'new' South Africa. Journal of Occupational and Organizational Psychology, 84, 453-470.

Noddings, N. (1984). Caring: a feminine approach to ethics and moral education. Berkeley, USA: University of California Press.

Northcott, R. (2016). Leading from the Front: Q\&A with Peter Hughes. Public Sector Journal, 39(3), 18-19.

Office of the Auditor General. (2004). The State Services Commission: capability to recognise and address issues for Maori. The report of the Controller and Auditor General. Retrieved from https://www.oag.govt.nz/2004/issues-for-maori/docs/issues-for-maori.pdf

Office of the Auditor General. (2015). Part 5: the senior leadership and management development strategy. Retrieved from http://www.oag.govt.nz/2004/issues-formaori/part5.htm?searchterm=Senior+leadership

Ohia, M. (2006). Towards a values based transformation movement for Māori advancement: the case for spiritual, ethical and moral imperatives withing Māori transformational movements (Unpublished thesis). University of Auckland, Auckland, New Zealand.

O'Leary, Z. (2010). The essential guide to doing your esearch project. $2^{\text {nd }}$ Ed. Los Angeles: Sage. 
Oliver, S. (2010). Te Rangi-puawhe, Te Keepa, from the Dictionary of New Zealand Biography. In Te Ara: the encyclopedia of New Zealand. Retrieved from https://teara.govt.nz/en/biographies/1t68/te-rangipuawhe-te-keepa

Orange, C. (1987). The Treaty of Waitangi. Wellington, New Zealand: Bridget Williams Books.

O'Regan, T., \& Mahuika, A. (1993). Modern day developments within Māori Society and the role of the Social Policy Agency as a provider of quality policy advice. Social Policy Journal of New Zealand, 1.

Ospina, S., \& Dodge, J. (2005). Narrative inquiry and the search for connectedness: practitioners and academics developing public administration scholarship. Public Administration Review, 65(4), 409-423.

Ospina, S., \& Foldy, E. (2009). A critical review of race and ethnicity in the leadership literature: surfacing context, power and the collective dimensions of leadership. Leadership Quarterly, 20(6), 876-896.

Pearce, C. L., \& Conger, J. A. (Eds.). (2003). Shared leadership: reframing the hows and whys of leadership. Thousand Oaks, USA: Sage Publications.

Pene, R \& Tapiata, J. (2011). Tūhourangi Auahi Ana E! Ngā moteatea o Tūhourangi. Te Wahanga Tuatahi Vol 1. New Zealand. Tuhourangi Iwi.

Penetito, W. (2011). What's Mãori about Mãori education. Wellington, New Zealand: Victoria University Press.

Pere, R. (1991). Te Wheke: a celebration of infinite wisdom. Gisborne, New Zealand: Ao Ako Global Learning New Zealand.

Pihama, L. (2001). Tihei mauriora: honouring our voices, manawahine as a kaupapa Māori theoretical framework (Unpublished doctoral dissertation). University of Auckland, Auckland, New Zealand.

Pihama, L., \& Gardiner, D. (2005). Building baseline data on Mãori whānau development and Mãori realising their potential. Literature review: developing Māori leadership. Auckland, New Zealand: Auckland UniServices.

Pihama, L., Smith, K., Taki, M., \& Lee, J. (2010). A literature review on kaupapa Māori and Māori education pedagogy. Retrieved from http://akoaotearoa.ac.nz/community/m\%C4\%81tauranga$\mathrm{m} \% \mathrm{C} 4 \% 81$ ori/resources/pages/literature-review-kaupapa-m\%C4\%81ori-and-m\%C4\%81ori-educationpedag

Pohatu, T. (2004). Ata: growing respectful relationships. Unpublished manuscript.

Puao-te-Ata-tu. (1988). Puao-te-Ata-tu. The report of the Ministerial Advisory Committee on a Maori perspective for the Department of Social Welfare. Wellington, New Zealand: Department of Social Welfare.

Puketapu, I. (1982). Reform from within? In C. Burns, The path to reform. New Zealand Institute of Public Administration. Wellington, New Zealand.

Radnor, H. (2001). Researching Your Professional Practice: Doing Interpretative Research. Buckingham, Philadelphia: Open University Press.

Raelin, J. (2011). From leadership-as-practice to leaderful practice. Leadership, 7, 195-211.

Raelin, J. (2015). Introduction to leadership-as-practice: theory and application. Manuscript in preparation.

Rangihau, J. (1975). Being Māori. In M. King (Ed.), Te ao hurihuri : the world moves on (pp. 221-233).

Wellington, New Zealand: Hicks Smith \& Sons.

Renati, P., \& Waaka, T. (2017). Te whānau a John rāua ko Lydia Riria Bean. Rotorua. Tūhourangi Wānanga.

Rewi, P. (2010). Whaikōrero: The World of Māori Oratory. Auckland: Auckland University Press 
Rhodes, R. (2014). Chapter 7. In Public administration (pp. 101-116). Retrieved from http://spp.xmu.edu.cn/wp-content/uploads/2014/05/Administrative-leadership.pdf

Riessman, C.K. (1993). Narrative Analysis. Qualitative Research Methods Series, No. 30. Newbury Park, CA: Sage.

Robson, C. (2002). Real world research: a resource for social scientists and practitioner-researchers. Massachussetts, USA: Blackwell Publishers.

Roche, M., Haar, J., \& Brougham, D. (2015). Māori leaders' wellbeing: a self-determination perspective. Leadership, 14(1), 25-39. Retrieved from doi: 10.1177/1742715015613426

Rooney (2005). Researching from the inside - does it compromise validity? Level3, 3. 1-19.

Royal, C. (1998). Te ao marama: A research paradigm. He Pukenga Korero. A Journal of Maori Studies, 4(1): $1-8$.

Royal, C. T. (2000). Pūrākau: a genre of story telling. Paper presented at the 10th Biennial Conference of History and Film Australia and New Zealand, Wellington, New Zealand.

Royal, C. (Ed.) (2003). The woven universe: selected writings of Rev. Mãori Marsden. Otaki, New Zealand: The estate of Rev. Māori Marsden.

Royal, T. A. C. (2006). A modern view of mana. Paper presented at the Joint Conference of the Australian Psychological Society and the New Zealand Psychological Society, SkyCity Auckland Convention Centre, Auckland, New Zealand.

Royal, T. A. C. (2007). Te aka matua. A te Tai Tokerau tradition concerning the Treaty of Waitangi. Ki Te Whaiao, Ki Te Ao Märama. Retrieved from http://www.charles-

royal.com/assets/te\%20aka\%20matuatow.pdf

Ruwhiu, D., \& Cone, M. (2013). Pragmatic leadership: A return to wisdom. Journal of Management \& Organization, 19(1), 25-43.

Ruwhiu, D., \& Elkin, G. (2016). Converging pathways of contemporary leadership: In the footsteps of Māori and servant leadership. Leadership, 12(3), 308-323.

Schaetti, B., Ramsey, S., \& Watanabe, G., (2008). Personal leadership: making a world of difference: a methodology of two principles and six practices. Seattle, USA: Flying Kite Publications.

Schick, A. (1996). The spirit of reform: managing the New Zealand state sector in a time of change. A Report Prepared for the State Services Commission and The Treasury. Wellington, New Zealand: State Services Commission and The Treasury.

Schon, D.A. \& Rein, M. (1994). Frame Reflection: Toward the resolution of intractable policy controversies. New York: Basic Books.

Selznick, P. (1957). Leadership in administration. New York: Row, Peterson and Company.

Selznick, P. (1984). Leadership in administration: A sociological interpretation. Berkeley, CA:

University of California Press.

Skerrett, M. (2010). A critique of the Best Evidence Synthesis with relevance for Māori leadership in education. Journal of Educationa Leadership, Policy and Practice, 25(1), 42-50.

Smith, G. H. (1997). The development of kaupapa Māori: theory and praxis. Auckland, New Zealand: University of Auckland. 
Smith, G. (2015). Graham Hingangaroa Smith. In S. Katene. Fire that kindles hearts: Ten Māori Scholars (pp 93-117). Wellington, New Zealand: Steele Roberts.

Smith, L. T. (1999). Decolonizing methodologies. Dunedin: University of Otago Press.

Smith, L. T. (2000). Kaupapa Māori research. In M. Battiste (Ed.), Reclaiming indigenous voice and vision (pp. 225-247). Vancouver, Canada: UBC Press.

Smith, L. (2005). On tricky ground: researching the native in the age of uncertainty. In N. Denzin, \& Y. Lincoln, SAGE handbook of qualitative research (3rd ed.) (pp. 85-107). Thousand Oaks, USA: Sage Publications.

Smith, L., \& Cram, F. (2001). Maori ethical frameworks. Retrieved from http://www.rangahau.co.nz/ethics/166/

Smith, L. T. (2006). Researching in the margins: issues for Māori researchers: a discussion paper. Alternative: An International Journal of Indigenous Peoples, 2(1), 4-27.

Smith, L., Maxwell, T.K.K., Puke, H., \& Te Mara, P. (2016). Indigenous knowledge, methodology and mayhem: What is the role of methodology in producing indigenous insights? A discussion from Mātauranga Māori. Knowledge Cultures, 4(3), 131-156.

Snedden, P. (2005). Rangatiratanga and leadership. Leaders, Spring edition.

Spillane, J. P. (2006) Distributed leadership. San Francisco, USA: Jossey-Bass.

Spiller, C., Erakovic, L., Henare, M., \& Pio, E. (2011). Relational well-being and wealth: Māori businesses and an ethic of care. Journal of Business Ethics, 98 (1): 153-169.

Spiller, C., \& Stockdale, M. (2012). Managing and leading from a Māori perspective: bringing new life and energy to organizations. In J. Neal (Ed.), Handbook for faith and spirituality in the workplace. New York, USA: Springer.

Starbuck, W. H., \& Milliken, F. J. (1988). Executives' perceptual filters: what they notice and how they make sense. In D. C. Hambrick (Ed.), The executive effect: concepts and methods for studying top managers (pp. 35-65). Greenwich, USA: JAI Press.

State Services Commission. (2005a). Report on the Performance of the New Zealand Qualifications Authority in the Delivery of Secondary School Qualifications. Retrieved from http://www.ssc.govt.nz/resources/2677/all-pages.

State Services Commission. (2005b). EEO policy to 2010: future directions of EEO in the New Zealand public service. Retrieved from State Services Commission: http://www.ssc.govt.nz/node/6422

State Services Commission. (2006). Chapter 9. In Māori in the public service. Retrieved from http://www.ssc.govt.nz/node/6422

State Services Commission (2007). Code of conduct for the State Services. Retreived from http://www.ssc.govt.nz/code

State Services Commission. (2014). Getting to great: your map to navigating the straits of internal leadership. Wellington, New Zealand: State Services Commission, the Treasury and the Department of the Prime Minister and Cabinet.

State Services Commission. (2016a). Human resource capability. Wellington, New Zealand: State Services Commission. Retrieved from http://www.ssc.govt.nz/hrc-survey-2016 
State Services Commission. (2016b). Leadership insight: initial findings. Wellington, New Zealand: State Services Commission.

Statistics New Zealand. (2002). Towards a Māori statistics framework. Retrieved from http://www.stats.govt.nz/browse_for_stats/people_and_communities/maori/towards-a-maori-statsframework.aspx

Suckling, S. (2009). Speech notes. Hui Mana Tohu Mātauranga Māori. Wellington, New Zealand: New Zealand Qualifications Authority.

Sundaramurthy, C., \& Lewis, M. (2003). Control and collaboration: paradoxes of governance. Academy of Management Review, 28, 397-415.

't Hart, P., \& Uhr, J. (2008). Public leadership perspectives and practices. In P. 't Hart, \& J. Uhr, Public leadership perspectives and practices. Canberra, Australia: ANU E Press.

Taki, M. (1996). Kaupapa Māori and contemporary iwi Mãori resistance. Auckland, New Zealand: University of Auckland.

Tapsell, P. (2012). Te Arawa - origins. In Te Ara: the encyclopedia of New Zealand. Retrieved from http://www.teara.govt.nz/en/te-arawa/page-1

Tawhai, V., \& Gray-Sharp, K. (2011). Always speaking: the Treaty of Waitangi and public policy. Wellington, New Zealand: Huia.

Tedlock, B. (2000). Ethnography and ethnographic representation. In N. K. Denzin, \& Y. S. Lincoln (Eds.), The handbook of qualitative research (2nd ed.). London, England: Sage Publications.

Te Puni Kōkiri. (2002). He tirohanga ō kawa ki te Tiriti o Waitangi: a guide to the principles of the Treaty of Waitangi as expressed by the courts and the Waitangi Tribunal. Wellington, New Zealand: Te Puni Kōkiri.

Te Puni Kōkiri. (2006a). Mãori potential framework: Annual Report. Retrieved from http://www.tpk.govt.nz/en/a-matou-mohiotanga/crown-maori-relations/engagemaori

Te Puni Kōkiri (2006b). Building Relationships for Effective Engagement with Māori. Retrieved from www.tpk.govt.nz/en/a-matou-mohiotanga/crown-maori-relations/crown-maori-relationshipinstruments

Te Puni Kōkiri (2006c). Crown-Māori Instruments: Guidelines and Advice for Government and State Sector Agencies. Retrieved from https://www.tpk.govt.nz/en/a-matou-mohiotanga/crownmaorirelations/crown-maori-relationship-instruments

Te Puni Kōkiri. (2007). Te wa o te ao hurihuri ki te ōhanga whanaketanga Māori: A time for a change in Māori economic development. Wellington: Author with the New Zealand Institute for Economic Research.

Terry, L. D. (1995). Leadership in public bureaucracies: the administrator as conservator. Thousand Oaks, USA: Sage Publications.

Te Whata, T., \& Kawharu, M. (2012). Transformations of entrepreneurial tribal Mãori leadership. Auckland, New Zealand: Ngā Pae o te Māramatanga.

The Latina Feminist Group. (2001). Telling to live: Latina feminist testimonios. Durham, NC: Duke University Press.

Thomas, R., \& Davies, A. (2005). Theorizing the micro-politics of resistance: new public management and managerial identities in the UK public services. Organization Studies, 1 [(number), page numbers]. Tierney, M. (1994). On method and hope. In A. Gitlin (Ed.), Power and method. London, England: Routledge. 
Tipene-Matua, B., Phillips, H., Cram, F., Parsons, M., \& Taupo, K. (2009). Old ways of having new conversations: basing qualitative research within tikanga Māori. Auckland, New Zealand: Katoa.

Turia, T. (2016). Institutional Racism - The evil whose time is up. New Zealand Herald. Retrieved from www.nzherald.co.nz/nz/news/article/.cfm?c_id=1\&objectid=11721558

Uhl-Bien, M. (2006). Relational leadership theory: exploring the social processes of leadership and organizing. Leadership Quarterly, 17(6), 654-676.

van Eeten, M. (2007). Narrative policy analysis. In F. Fischer, G. Miller, \& M. Sidney, Handbook of public policy analysis: theory, politics and methods (pp. 251-288). Boca Raton, USA: CRC Press.

Van Wart, M. (2003). Public sector leadership theory: an assessment. Public Administration Review, 63(2), 214-228.

Waitangi Tribunal. (2011). Wai 262: Ko Aotearoa tēnei: a report into claims concerning New Zealand law and policy affecting Māori culture and identity. Wellington, New Zealand. Retrieved from [provide specific URL, or delete URL]

Waitangi Tribunal. (2017a). Tū mai te rangi! Report on the crown and disproportionate reoffending rates. Wellington, New Zealand. Retrieved from provide specific URL, or delete URL]

Waitangi Tribunal. (2017b). Meaning of the Treaty: a Treaty of two texts. Retrieved from https://www.waitangitribunal.govt.nz/treaty-of-waitangi/meaning-of-the-treaty/

Walker, R. (1990). Ka whawhai tonu matou: struggle without end. Auckland, New Zealand: Penguin.

Walker, R. (1993). Tradition and change in Māori leadership. Auckland, New Zealand: University of Auckland.

Walker, R. (1996). Ngā pepa a Ranginui: the Walker papers. Auckland, New Zealand: Penguin.

Walker, R. (2005). Quality Assurance in tertiary eduction from a Mãori (indigenous) perspective. Paper presented at the International Network for Quality Assurance Agencies in Higher Education Conference, Wellington, New Zealand. Retrieved from http://www.inqaahe.org/sites/default/files/pictures/Quality\%20Assurance\%20in\%20Tertiary\%20Edu cation $\% 20$ from $\% 20$ a\%20Maori\%20\%28indignous\%29\%20Perspectiv\%20Ranginui_Walker.pdf

Weick, K.E. (1995). Sensemaking in Organisations. Thousand Oaks, CA: Sage Publications, Inc.

Williams, H. (1992). Dictionary of the Mãori language. Wellington, New Zealand: Government Printer.

Williams, I., \& Shearer, H. (2011). Appraising public value: past, present and futures. Public Administration, 89(4), 1367-1384.

Williams, J. (2010). Māori leadership. Presentation at Waipapa Marae, University of Auckland, Auckland, New Zealand.

Wilson, D., \& Baker, M. (2012). Bridging two worlds: Māori mental health nursing. Qualitative Health Research. 22(8) 1073-1082. Sage.

Winiata, M. (1967). The changing role of the leader in Maori society. Auckland, New Zealand: Blackwood and Janet Paul.

Winiata, PB. (2001). Leaders Are Made Not Just Born_Planning for Leaders and Leadership succession. A presentation to FIRST Young Māori Leaders Conference, Wellington.

Wolfgramm, R., Spiller, C., \& Voyageur, C. (2016). Special issue: indigenous leadership - editors' introduction. Leadership, 12(3), 263-269. 
Workman, K. (1995). Biculturalism in the public service: revisiting the kaupapa. Wellington, New Zealand: Ministry of Health. 